VILNIAUS GEDIMINO TECHNIKOS UNIVERSITETAS

Mindaugas LUNECKAS

\title{
ŠEŠIAKOJO ROBOTO JUDÉJIMO ENERGETINIO EFEKTYVUMO TYRIMAS
}

DAKTARO DISERTACIJA

TECHNOLOGIJOS MOKSLAI,

ELEKTROS IR ELEKTRONIKOS INŽINERIJA (01T) 
Disertacija rengta 2014-2018 metais Vilniaus Gedimino technikos universitete.

\section{Vadovas}

doc. dr. Dainius UDRIS (Vilniaus Gedimino technikos universitetas, elektros ir elektronikos inžinerija - 01T).

Vilniaus Gedimino technikos universiteto Elektros ir elektronikos inžinerijos mokslo krypties disertacijos gynimo taryba:

\section{Pirmininkas}

prof. dr. Algirdas BAŠKYS (Vilniaus Gedimino technikos universitetas, elektros ir elektronikos inžinerija -01T).

\section{Nariai:}

prof. dr. Stjepan BOGDAN (Zagrebo universitetas, Kroatija, elektros ir elektronikos inžinerija - 01T),

prof. dr. Artūras SERACKIS (Vilniaus Gedimino technikos universitetas, elektros ir elektronikos inžinerija - 01T),

prof. habil. dr. Rimvydas SIMUTIS (Kauno technologijos universitetas, informatikos inžinerija - 07T),

doc. dr. Voitech STANKEVIČ (Valstybinis mokslinių tyrimų institutas Fizinių ir technologijos mokslų centras, fizika-02P).

Disertacija bus ginama viešame Elektros ir elektronikos inžinerijos mokslo krypties disertacijos gynimo tarybos posėdyje 2018 m. gegužès 18 d. 13 val. Vilniaus Gedimino technikos universiteto Senato posėdžių salèje.

Adresas: Sauletekio al. 11, LT-10223 Vilnius, Lietuva.

Tel.: (8 5) 274 4956; faksas (8 5) 270 0112; el. paštas doktor@vgtu.lt

Pranešimai apie numatomą ginti disertaciją išsiųsti $2018 \mathrm{~m}$. balandžio $17 \mathrm{~d}$.

Disertaciją galima peržiūrèti VGTU talpykloje http://dspace.vgtu.lt ir Vilniaus Gedimino technikos universiteto bibliotekoje (Sauletekio al. 14, LT-10223 Vilnius, Lietuva) bei Lietuvos mokslų akademijos Vrublevskių bibliotekoje (Žygimantų g. 1, LT-01102).

VGTU leidyklos TECHNIKA 2018-015-M mokslo literatūros knyga http://leidykla.vgtu.lt

ISBN 978-609-476-103-4

(C) VGTU leidykla TECHNIKA, 2018

(C) Mindaugas Luneckas, 2018

mindaugas.luneckas@vgtu.lt 
VILNIUS GEDIMINAS TECHNICAL UNIVERSITY

Mindaugas LUNECKAS

\section{INVESTIGATION OF ENERGY EFFICIENCY OF HEXAPOD ROBOT LOCOMOTION}

DOCTORAL DISSERTATION

TECHNOLOGICAL SCIENCES,

ELECTRICAL AND ELECTRONIC ENGINEERING (01T) 
Doctoral dissertation was prepared at Vilnius Gediminas Technical University in 2014-2018.

\section{Supervisor}

Assoc. Prof. Dr Dainius UDRIS (Vilnius Gediminas Technical University, Electrical and Electronic Engineering - 01T).

The Dissertation Defense Council of Scientific Field of Electrical and Electronic Engineering of Vilnius Gediminas Technical University:

\section{Chairman}

Prof. Dr Algirdas BAŠKYS (Vilniaus Gediminas Technical University, Electrical and Electronic Engineering - 01T).

\section{Members:}

Prof. Dr Stjepan BOGDAN (University of Zagreb, Croatia, Electrical and Electronic Engineering - 01T),

Prof. Dr Artūras SERACKIS (Vilniaus Gediminas Technical University, Electrical and Electronic Engineering - 01T),

Prof. Dr Habil. Rimvydas SIMUTIS (Kaunas University of Technology, Informatics Engineering - 07T),

Assoc. Prof. Dr Voitech STANKEVIČ (State Research Institute Center for Physical Sciences and Technology, Physics - 02P).

The dissertation will be defended at the public meeting of the Dissertation Defence Council of Electrical and Electronic Engineering in the Senate Hall of Vilnius Gediminas Technical University at 1 a. m. on 18 May 2018.

Address: Saulètekio al. 11, LT-10223 Vilnius, Lithuania.

Tel.: +370 5274 4956; fax +370 5270 0112; e-mail: doktor@vgtu.lt

A notification on the intend defending of the dissertation was send on 17 April 2018.

A copy of the doctoral dissertation is available for review at VGTU repository http://dspace.vgtu.lt and at the Library of Vilnius Gediminas Technical University (Sauletekio al. 14, LT-10223 Vilnius, Lithuania) and the Wroblewski Library of the Lithuanian Academy of Sciences (Žygimantų st. 1, LT-01102). 


\section{Reziumè}

Disertacijoje nagrinėjamos vaikščiojančių robotų energijos sąnaudų problemos jiems judant lygiu ir nelygiu paviršiumi. Pagrindinis tyrimo objektas yra vaikščiojančio roboto valdymo, aplinkos atpažinimo bei kliūčių išvengimo žinomoje aplinkoje metodas. Energijos sąnaudų minimizavimas leistų praplèsti vaikščiojančiu robotų pritaikymą ir veikimo laiką. Pagrindinis darbo tikslas sukurti energijos sąnaudų minimizavimo metodus vaikščiojantiems robotams ir sukurti aplinkos atpažinimo ir klasifikavimo metodus bei ištirti šešiakojo roboto energijos sąnaudas jiems judant žinomoje aplinkoje. Šie metodai gali būti taikomi vaikščiojantiems daugiakojams robotams.

Darbe sprendžiami šie uždaviniai: šešiakojo roboto eisenos parinkimas atsižvelgiant i energijos sąnaudas, paviršiaus kliūčių aptikimo ir perlipimo metodų sudarymas ir jų efektyvumo palyginimas. Taip pat sprendžiami uždaviniai, kurie siejasi su pèdų trajektorijos generavimo metodo kūrimu bei kliūčių dydžio ir tankio įtaka roboto energijos sąnaudoms.

Disertaciją sudaro ivvadas, trys skyriai, bendrosios išvados, naudotos literatūros ir autoriaus publikacijų disertacijos tema sąrašai.

Ivade aptariama tiriamoji problema, darbo aktualumas, aprašomas tyrimų objektas, formuluojamas darbo tikslas bei uždaviniai, aprašoma tyrimų metodika, darbo mokslinis naujumas, darbo rezultatų praktiné reikšmé, ginamieji teiginiai. Ivado pabaigoje pristatomos disertacijos tema autoriaus paskelbtos publikacijos ir pranešimai konferencijose bei disertacijos struktūra.

Pirmasis skyrius skirtas literatūros apžvalgai. Jame pateikta mobiliujų robotų energetinio efektyvumo bei energijos sąnaudų matavimo, skaičiavimo ir optimizavimo metodų analizè.

Antrajame skyriuje pateiktas energetiškai efektyvaus judejjimo metodikos sudarymas vaikščiojantiems robotams. Šiame skyriuje pateiktas šešiakojo roboto matematinio ir fizinio modelių sudarymas, nelygaus paviršiaus klasifikavimo modelio sudarymas bei taktilinio kliūčiu aptikimo bei perlipimo metodų sudarymas. Skyriaus gale pateikiamos išvados.

Trečiajame skyriuje tiriamos energijos sąnaudų priklausomybès nuo roboto eisenos bei judèjimo parametrų, kliūčių aptikimo ir perlipimo tikslumas priklausomai nuo kliūčių skaičiaus roboto kelyje, taip pat kliūčių dydžio ir tankio itaka roboto energijos sąnaudoms.

Disertacijos tema paskelbti 9 straipsniai: keturi - Clarivate Analytics Web of Science duomenų bazès leidiniuose, turinčiuose citavimo rodiklį, trys Clarivate Analytics Web of Science duomenų bazès "Conference Proceedings“ leidiniuose ir du - kituose recenzuojamuose mokslo leidiniuose. Disertacijos tema perskaityti 7 pranešimai konferencijose Lietuvoje bei kitose šalyse. 


\section{Abstract}

In this dissertation the issues of walking robots' energetic efficiency while walking on even and irregular terrain using gait switching and tactile obstacle avoidance methods are investigated. The main object of research is methods for walking robot's locomotion, environment recognition, and obstacle avoidance. The importance of walking robots is their ability to overcome irregular terrain and adaptation to environment. The minimization of energy consumption would improve the use of walking robots and extend their working time. The primary purpose of this dissertation is to develop and investigate environment recognition and classificaion methods, energetically efficient locomotion method for walking robots. Walking multilegged robots is a field for applying created methods. The dissertation also focuses on investigating energy consumption dependence on obstacle size and density.

The thesis approaches a few major tasks such as gait selection, obstacle detection and avoidance using tactile leg sensors. Second task is related to development of foot trajectory generation and obstacle size and density influence on robot's energy consumption.

The dissertation consists of introduction, three chapters, general conclusions and references.

The introduction reveals the investigated problem, importance of the thesis and the object of research and describes the purpose and tasks of the thesis, research methodology, scientific novelty, the practical significance of results examined in the paper and defended statements. The introduction ends in presenting the author's publications on the subject of the defended dissertation, offering the material of made presentations in conferences and defining the structure of the dissertation.

Chapter 1 revises used literature. Energetic efficiency of mobile robots is discussed along with energy consumption measurement, calculation and optimization methods. At the end of the chapter, conclusions are drawn and the tasks for the dissertation are reconsidered.

Chapter 2 describes the development of energetically efficient methodology for walking robots. Conclusions are presented at the end of the chapter.

Chapters 3 investigates the energy consumption dependence on movement parameters as well as obstacle avoidance.

9 articles focusing on a topic of the dissertation are published: four - in Clarivate Analytics Web of Science data base cited journals, three - in Clarivate Analytics Web of Science data base "Conference Proceedings" material and two - in other data bases. 7 conference reports were carried out focusing on a topic of the dissertation in Lithuania and abroad. 


\section{Žymèjimai}

\section{Simboliai}
$A_{1}, A_{2}, A_{3}$ - sąnarių transformacijos matricos;
$C O T$ - transportavimo kaštų vertė;
$D$ - kliūčių tankis;
$d$ - roboto nueitas kelias;
$d_{\mathrm{k}}$ - vienos roboto pėdos trajektorijos ilgis;
$E_{\mathrm{c}}$ - vieno roboto judejjimo ciklo energijos sąnaudos;
$E_{k i}-i$-osios roboto kojos pavarų energijos sąnaudos;
$E_{\text {kin }}$ - kinetinès energijos vertè;
$E_{\text {opt }}$ - energijos sąnaudų vertė su žingsnio parametrų parinkimu;
$E_{\mathrm{p}}$ - pilnutinès roboto energijos verte;
$E_{\text {pot }}$ - potencinès energijos verté;
$E_{\mathrm{v}}$ - roboto valdymo sistemos energijos sąnaudos; 
$E_{\text {vid }}$ - vidutinè energijos sąnaudų vertè;

$E_{\text {vid_opt }}$ - vidutinè energijos sąnaudų vertè su žingsnio parametrų parinkimu;

$F_{\mathrm{d}}$ - standumo jèga;

$F_{\mathrm{s}}$ - svorio jèga;

$F_{\mathrm{t}}$ - trinties jëga;

$F_{\text {tr }}$ - traukos jèga;

$H$ - kliūties aukštis;

$h$ - žingsnio aukštis;

$h_{\mathrm{i}}$ - žingsnio aukštis judant lygiu paviršiumi;

$h_{\mathrm{k}}-$ žingsnio aukštis perlipant kliūtį;

$h_{\max }-$ maksimalus žingsnio aukštis;

$I_{k}$ - vienos roboto kojos pavarų elektros srovès stipris;

$I_{\text {vid }}$ - vidutinis roboto pavaroms tenkantis elektros srovès stipris;

$K-$ kliūčių skaičius aplinkoje;

$L$ - kliūties ilgis;

$L_{1}, L_{2}, L_{3}-$ klubo, šlaunies ir blauzdos kojos dalių ilgiai;

$l$ - žingsnio ilgis;

$l_{\mathrm{i}}$ - žingsnio ilgis judant lygiu paviršiumi;

$l_{\mathrm{k}}$ - žingsnio ilgis perlipant kliūtį;

$l_{\max }$ - maksimalus žingsnio ilgis;

$m_{i}-i$-osios roboto kojos mase;

$m_{\mathrm{k}}$ - roboto kūno masé;

$N$ - roboto kūno pakèlimo aukštis;

$n$ - roboto kojų skaičius;

$P(x, y, z)$ - roboto pèdos padètis erdveje;

$P_{k}$ - vienos roboto kojos pavarų vartojamos galios verte். 
$P_{\text {vid }}$ - vidutinè galios verte;

$S$ - judejjimo ciklų skaičius;

$\bar{S}$ - judejjimo ciklų skaičius lipant per kliūtis;

$s$ - žingsnio lanko ilgis;

$S_{\mathrm{p}}-$ pilnutinis roboto judejimo kelio ilgis;

$T$ - eisenos periodas;

$T_{3}^{0}-3$ laisvès laipsnių transformacijos matrica;

$t_{k}$ - vienos kojos perkèlimo laikas;

$t_{\mathrm{p}}$ - pilnutinis roboto veikimo laikas;

$t_{\text {traj }}$ - vienos roboto kojos žingsnio atlikimo laikas, kai kojų judesiai yra sinchronizuoti laiko atžvilgiu;

$v$ - roboto judejimo greitis;

$v_{\text {vid }}-$ vidutinis roboto kojos judejimo greitis;

$W$ - kliūties plotis;

$w$ - žingsnio plotis;

$w_{\mathrm{i}}$ - žingsnio plotis judant lygiu paviršiumi;

$w_{\max }$ - maksimalus žingsnio plotis;

$\Delta E_{\text {vid- }}$ - energijos sąnaudų vertès nuokrypa nuo vidutinès vertès ị žemesnę pusę;

$\Delta E_{\text {vid+ }}$ - energijos sąnaudų vertès nuokrypa nuo vidutinès vertès ị didesnę pusę;

$\Delta I_{\text {vid- }}$ - elektros srovès stiprio nuokrypa nuo vidutinès vertès į žemesnę pusę;

$\Delta I_{\text {vid }+}$ - elektros srovès stiprio nuokrypa nuo vidutinès vertè ị didesnę pusę;

$\Delta t$ - laiko prieaugis dèl atsitrenkimų i kliūtis;

$\Delta t_{\max }-$ maksimalus vienos roboto kojos žingsnio atlikimo laikas;

$\Delta t_{\min }-$ minimalus vienos roboto kojos žingsnio atlikimo laikas;

$\varepsilon$ - roboto judejjimo kryptis;

$\varphi_{i}-i$-osios kojos perkèlimo fazé;

$\theta_{1}, \theta_{2}, \theta_{3}-$ klubo, šlaunies ir blauzdos sąnarių kampai. 


\section{Santrumpos}

DG - dešinè galinė roboto koja;

D-H - Denavito-Hartenbergo parametrai;

DP - dešinè priekinè roboto koja;

DV - dešinè vidurinè roboto koja;

$\mathrm{KG}$ - kairè galinè roboto koja;

$\mathrm{KP}$ - kaire priekinè roboto koja;

$\mathrm{KV}$ - kaire vidurinè roboto koja;

LL - laisvès laipsniai;

$\mathrm{SP}$ - servo pavara. 


\section{Turinys}

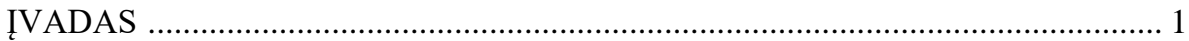

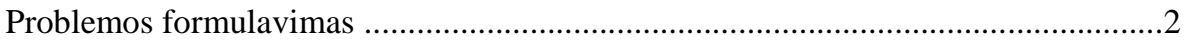

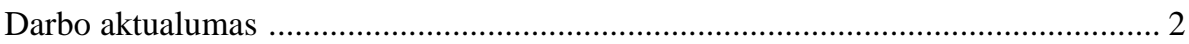

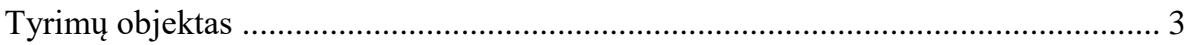

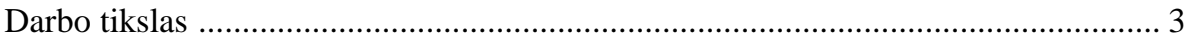

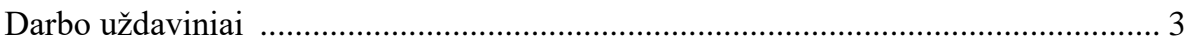

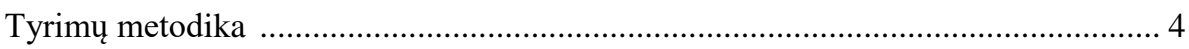

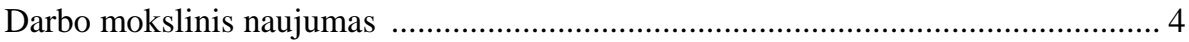

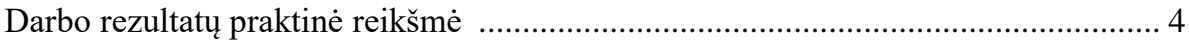

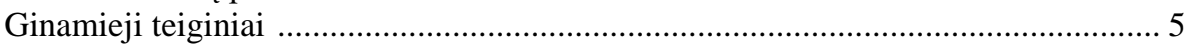

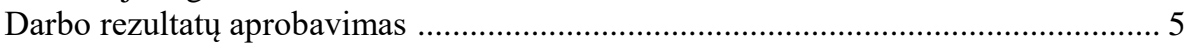

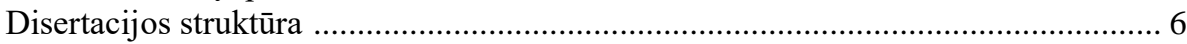

1. MOBILIŲJŲ ROBOTŲ ENERGIJOS SĄNAUDŲ ANALIZĖ .................................. 7

1.1. Vaikščiojantys robotai ir jų energijos sąnaudos ............................................. 7

1.1.1. Vaikščiojančių robotų tipai ir jų valdymo metodai ................................. 8

1.1.2. Vaikščiojančių robotų mažo energetinio efektyvumo priežastys ........... 13

1.2. Robotų energijos sąnaudų matavimas ir skaičiavimas ...................................... 14

1.3. Energijos sąnaudų minimizavimo metodai .................................................. 17

1.4. Pirmojo skyriaus išvados ir disertacijos uždavinių formulavimas..................... 21 
2. ENERGETIŠKAI EFEKTYVAUS JUDĖJIMO METODŲ SUDARYMAS .......... 23

2.1. Šešiakojo roboto matematinio ir fizinio modelių sudarymas ........................... 24

2.2. Paviršiaus klasifikavimo modelio sudarymas ..................................................... 36

2.3. Kliūčiu aptikimo ir perlipimo metodų sudarymas ............................................ 43

2.3.1. Kliūčių aptikimas ir ịvertinimas ............................................................. 44

2.3.2. Pėdos trajektorijos generavimas …………........................................ 46

2.4. Energijos sąnaudų matematinis modelis ............................................................ 49

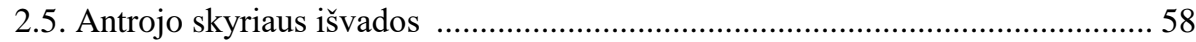

3. ŠEŠIAKOJO ROBOTO ENERGETINIO EFEKTYVUMO TYRIMAI .................61

3.1. Šešiakojo roboto energetinio efektyvumo tyrimai judant lygiu paviršiumi ...... 62

3.2. Roboto judèjimo per kliūtis tyrimas ……………............................................ 72

3.3. Energijos sąnaudų minimizavimo judant per kliūtis tyrimas ............................... 78

3.4. Energijos sąnaudų priklausomybès nuo kliūčių dydžio ir tankio tyrimas .........86

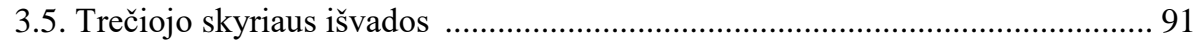

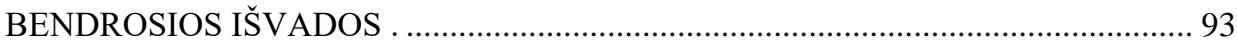

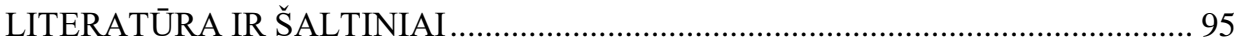

AUTORIAUS MOKSLINIŲ PUBLIKACIJŲ DISERTACIJOS TEMA SĄRAŠAS ..105

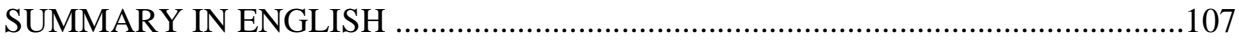

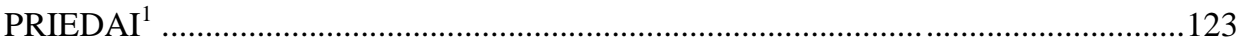

A priedas. Disertacijos autoriaus sąžiningumo deklaracija ....................................126

B priedas. Bendraautorių sutikimai teikti publikacijų medžiagą disertacijoje ......127

C priedas. Autoriaus mokslinių publikacijų disertacijos tema kopijos ..................135

${ }^{1}$ Priedai pateikiami pridètoje kompaktinèje plokštelëje. 


\section{Contents}

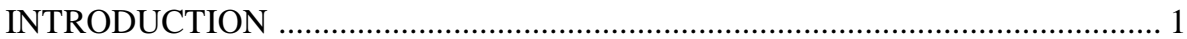

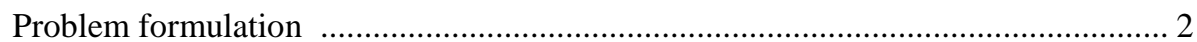

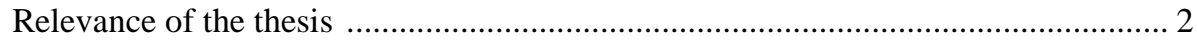

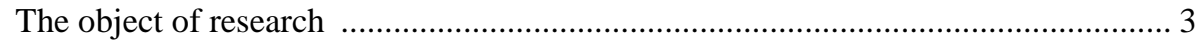

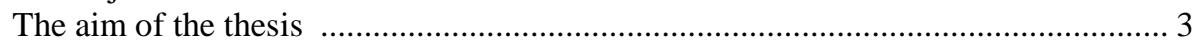

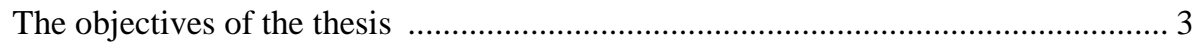

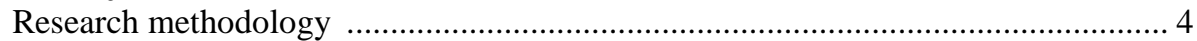

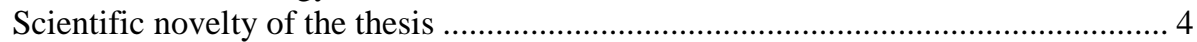

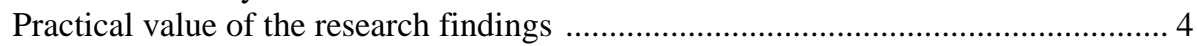

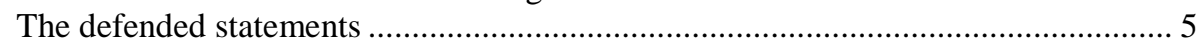

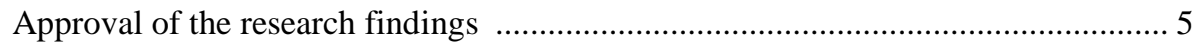

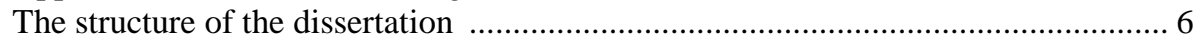

1. MOBILE ROBOTS' ENERGETIC EFFICIENCY ANALYSIS ……………......... 7

1.1. Walking robots and their energy consumption .............................................. 7

1.1.1. Walking robots' types and their control methods ................................ 8

1.1.2. Walking robots' low energy efficiency causes .................................... 13

1.2. Methods for measuring and calculating robot's energy consumption .............. 14

1.3. Energy consumption minimization methods ................................................... 17

1.4. First chapter conclusions and formulation of the thesis objectives ................... 21 
2. FORMATION OF ENERGY EFFICIENT LOCOMOTION METHODS

2.1. Development of hexapod robot mathematical and physical models ............... 24

2.2. Development of terrain classification model ............................................ 36

2.3. Development of obstacle detection and avoidance methods ........................ 43

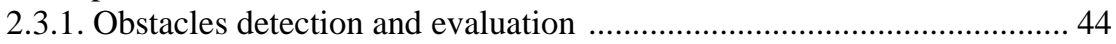

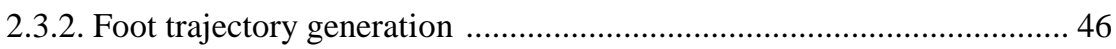

2.4. Mathematical model of energy consumption ......................................... 49

2.5. Second chapter conclusions ............................................................. 58

3. RESEARCH OF HEXAPOD ROBOT ENERGETIC EFFICIENCY .................... 61

3.1. Hexapod robot energetic efficiency while moving on even terrain .................. 62

3.2. Investigation of robot movement over obstacles ..................................... 72

3.3. Energy consumption minimization while moving over obstacles .................... 78

3.4. Research of energy consumption dependence on difficulty of environment .... 86

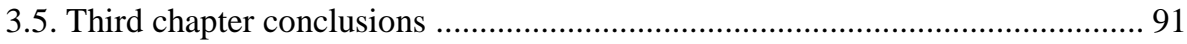

GENERAL CONCLUSIONS _......................................................................... 93

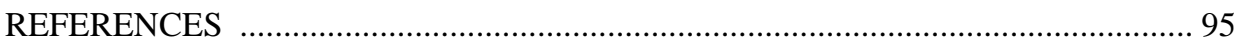

LIST OF THE AUTHOR'S SCIENTIFIC PUBLICATIONS BY THE AUTHOR ON

THE TOPIC OF THE DISSERTATION ....................................................... 105

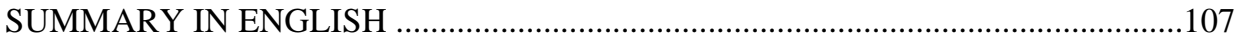

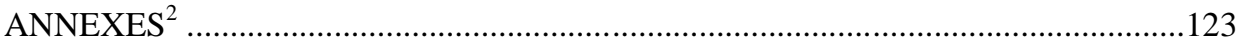

Annex A. Author's declaration of academic integrity ....................................126

Annex B. Co-author's agreements to present publications material in the doctoral

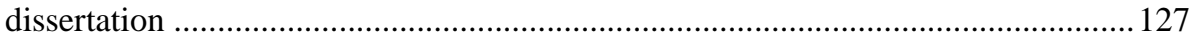

Annex C. Copies of scientific publications by the author on the topic of the dissertation

${ }^{2}$ The annexes are supplied in the enclosed compact disc. 


\section{Ivadas}

\section{Problemos formulavimas}

Nelygiems paviršiams įveikti, judėjimui sudètingose bei žmogui pavojingose aplinkose yra tinkamiausi vaikščiojantys robotai, kurie pasižymi dideliu kojų ir laisvès laipsnių skaičiumi (G. C. Haynes et. al. 2012, X. Xiong et. al. 2015). Didelis laisvès laipsnių skaičius padidina vaikščiojančių robotų lankstumą, judejjimo galimybes ir gebèjimą perlipti nelygų paviršių. Visi dvikojai, keturkojai ar šešiakojai robotai gali turèti nuo aštuonių iki dvidešimt ar net daugiau laisvès laipsnių. Kiekvienas laisvės laipsnis kuriamas naudojant ịvairias pavaras, ir dèl to stipriai dideja energijos sąnaudos. Mažinant laisvès laipsnių skaičių mažéja mobilaus roboto manevringumas ir kojų ar rankų darbo zona. Todẻl energetiškai efektyvus judèjimas turi būti pasiektas pritaikant kitokio pobūdžio metodus, pavyzdžiui, optimizuojant judesius. Judejjimui nelygiu paviršiumi ar lipant per ịvairias paviršiaus kliūtis reikalingi aplinkos atpažinimo jutikliai, o taip pat kliūčių ìveikimo metodai. Toks judejjimas reikalauja roboto judejjimo parametrų bei eisenos pakeitimų. Taigi kuriant energetiškai efektyvaus judejjimo metodiką vaikščiojantiems robotams būtina ištirti energijos sąnaudų priklausomybes nuo roboto judèjimo parametrų bei kliūčių dydžio ir tankio.

Sudarant energetiškai efektyvų roboto judejjimo metodą judejjimui lygiu paviršiumi sprendžiama eisenos parinkimo pagal roboto judèjimo greitị problema. 
problema. Tokiai problemai spręsti reikia atlikti išsamius energijos sąnaudų priklausomybès nuo judèjimo greičio bei eisenos tyrimus, kurie leistų tinkamai ivvertinti sąryšị tarp šių parametrų.

Judejjimui per kliūtis dažnai taikomas pèdų pozicionavimo planavimo metodas (M. Kalakrishnan et. al. 2011), kuris remiasi kiekvienos kojos padèties koordinačių skaičiavimu visai numatytai judejjimo trajektorijai. Naudojant šị metodą, robotas gauna išankstinę informaciją, kur kuriuo metu kiekviena koja turès atsistoti. Tačiau toks metodas yra gana sudètingas ir, jei atliekami skaičiavimai realiu laiku, stipriai sulètèja roboto judèjimas. Kliūčių aptikimui ir išvengimui gali būti naudojami ir tinkamų judejjimo parametrų parinkimo ar pédos trajektorijos transformavimo metodai, kurie yra daug paprastesni ir realiu laiku gali veikti nekeičiant roboto judejjimo greičio.

Disertacijoje atlikti energijos sąnaudų priklausomybès nuo eisenos tyrimai ir išspręstos kliūčių aptikimo bei perlipimo metodų kūrimo problemos. Šie metodai buvo pritaikyti energetiškai efektyviam roboto judejimui žinomoje aplinkoje, kai robotas turi išankstinę informaciją apie kliūčių dydžius.

\section{Darbo aktualumas}

Energetiškai efektyvus judèjimas - tai pati svarbiausia vaikščiojančių robotų problema, kuri apima roboto kūrimo bei valdymo klausimus. Tokia problema yra glaudžiai susijusi su judejimo parametrų optimizavimu. Šios problemos sprendimo rezultatai turi didelę reikšmę kuriant energetiškai efektyvaus judejimo vaikščiojantiems robotams metodiką.

Energetiškai efektyvaus judejjimo problemos sprendimas prasideda roboto kūrimo metu. Nèra bendros metodikos, kuria naudojantis būtų galima sukurti energetiškai efektyvų robotą. Iprastinio roboto kūrimo metu nèra taikomi energijos sąnaudų minimizavimo metodai, o taip pat nèra atsižvelgiama ị laisvejs laipsnių skaičiu ar pavarų energetinị efektyvumą. Taip pat susiduriama su roboto valdymo problemomis judant tiek lygiu, tiek ir nelygiu paviršiumi. Klasikiniai roboto valdymo metodai, tokie kaip atvirkštinè kinematika, atvirkštinè dinamika yra būtini, tačiau nèra taikomi kuriamo roboto energetinio efektyvumo ịvertinimui. Judant nelygiu paviršiumi būtinos ịvairios aplinkos atpažinimo sistemos, kurios didina energijos sąnaudas, todèl atsiranda poreikis kurti metodus, leidžiančius tobulinti ne tik roboto valdymą, bet ir roboto energetinị efektyvumą.

Vaikščiojantys robotai gali būti ịvairių rūšių: dvikojai, keturkojai, šešiakojai ar net turèti ir daugiau kojų, gali būti valdomi vien kinematiniais metodais arba ir kinematiniais, ir dinaminiais. Atliekant energetinio efektyvumo tyrimus robotui judant lygiu paviršiumi ir perlipant kliūtis galima sukurti bendrą energetiškai efektyvaus judējimo metodiką, tinkamą visiems vaikščiojantiems 
robotams nepriklausomai nuo jų struktūros, valdymo sistemos ar veikimo algoritmo.

\section{Tyrimų objektas}

Darbo tyrimų objektas - šešiakojo vaikščiojančio roboto valdymo metodas, skirtas judejjimui lygiu paviršiumi bei kliūčių aptikimui bei perlipimui.

\section{Darbo tikslas}

Šio darbo pagrindinis tikslas yra sukurti ir ištirti lygiu paviršiumi judančių bei kliūtis perlipančių vaikščiojančių robotų energijos sąnaudų minimizavimo metodus.

\section{Darbo uždaviniai}

Darbo tikslui pasiekti darbe reikia spręsti šiuos uždavinius:

1. Sudaryti šešiakojo roboto imitacinị ir fizinị modelius bei pèdų trajektoriju generavimo matematines išraiškas kliūčių perlipimui.

2. Ištirti roboto energijos sąnaudas ir jas lemiančius veiksnius judant lygiu paviršiumi ir ịvertinti judejjimo nuokrypius nuo numatytos judejjimo trajektorijos žingsniuojant paviršiais su ịvairaus dydžio ir tankio kliūtimis.

3. Sudaryti ir ištirti pèdų trajektorijų generavimo metodą, kuris galètų būti naudojamas parinkti žingsnio parametrus siekiant minimizuoti energijos sąnaudas.

4. Ištirti roboto energijos sąnaudų priklausomybę nuo kliūčių dydžio ir tankio aplinkoje, taikant sudarytą pėdų trajektorijų generavimo metodą. 


\section{Tyrimų metodika}

Darbe taikomi geometrinis skaičiavimo bei Denavito-Hartenbergo metodai šešiakojo roboto atvirkštinès kinematikos sudarymui, parametrų parinkimo metodas energijos sąnaudų minimizavimo perlipant kliūtis tyrimui atlikti, matematinio modeliavimo bei eksperimentinių tyrimų metodai.

\section{Darbo mokslinis naujumas}

Rengiant disertaciją buvo gauti šie elektros ir elektronikos inžinerijos mokslui nauji rezultatai:

1. Sudarytas eisenos parinkimo algoritmas šešiakojams vaikščiojantiems robotams atsižvelgiant i roboto greiti, kurị naudojant galima minimizuoti roboto energijos sąnaudas judant lygiu paviršiumi.

2. Sukurtas naujas kliūčiu aptikimo ir perlipimo metodas vaikščiojantiems robotams, kurị naudojant galima realiu laiku nustatyti kliūčių padètị aplinkoje ir jas perlipti.

3. Sukurtas naujas pédos trajektorijos generavimo metodas, kuri naudojant robotas gali perlipti žinomo dydžio kliūtis ir parinkti žingsnio parametrus, siekiant sunaudoti minimalų energijos kiekị.

\section{Darbo rezultatų praktinè reikšmè}

1. Sudarytas šešiakojo vaikščiojančio roboto matematinis modelis, kurį naudojant galima patikrinti sukurtu metodų efektyvumą ir adekvatumą. Šis modelis išsiskiria galimybe teoriškai skaičiuoti vaikščiojančių robotų energijos sąnaudas.

2. Sukonstruotas šešiakojo vaikščiojančio roboto fizinis modelis, kuris gali būti taikomas ịvairiems moksliniams šešiakojų vaikščiojančių robotų judejimo ir energijos sąnaudų tyrimams atlikti.

3. Parinkta elektros srovės stiprio matavimo schema gali būti taikoma mobiliam robotui tenkančio elektros srovès stiprio matavimui, kuris yra būtinas norint ịvertinti roboto energijos sąnaudas.

4. Sukonstruoti ant roboto kojų priekinių dalių montuojami kliūčių aptikimo jutikliai. Naudojant šiuos jutiklius, robotas gali nustatyti, kada kiekviena koja remiasi ị kliūtį. 


\section{Ginamieji teiginiai}

1. Taikant eisenos pakeitimo algoritmą priklausomai nuo roboto judejjimo lygiu paviršiumi greičio gali būti gaunamos iki $21 \%$ mažesnès energijos sąnaudos parenkant banguojančią ir trikoję eisenas, lyginant su energijos sąnaudomis netaikant eisenos pakeitimo metodo.

2. Netaikant kliūčių perlipimo metodo galimi nuokrypiai nuo numatytos judejjimo trajektorijos gali siekti iki $24 \%$. Taikant kliūčiu perlipimo metodą darbe naudotam šešiakojui robotui judejjimui žinomoje aplinkoje nuokrypiai nuo numatytos trajektorijos gali būti sumažinti iki $12 \%$.

3. Taikant pėdos trajektorijos generavimo metodą judejjimui per ìvairaus žinomo dydžio kliūtis galima pasiekti iki $15 \%$ mažesnes energijos sąnaudas, lyginant su judejjimu netaikant pėdos trajektorijos generavimo metodo.

4. Kliūčių tankis aplinkoje stipriai įtakoja roboto energijos sąnaudas (apie $83 \mathrm{~J} / \mathrm{kliūčiai),} \mathrm{tačiau} \mathrm{kliūčių} \mathrm{aukštis} \mathrm{energijos} \mathrm{sąnaudoms} \mathrm{turi}$ labai mažą įtaką (apie $0,00022 \mathrm{~J} / \mathrm{cm}$ ), jei kliūčių aukštis yra mažesnis už roboto dydį. Kiekviena papildoma kliūtis viename šešiakojo roboto kelio metre energijos sąnaudas padidina iki $7 \%$.

\section{Darbo rezultatų aprobavimas}

Disertacijos tema yra atspausdinti 9 moksliniai straipsniai: keturi - Clarivate Analytics Web of Science duomenų bazès leidiniuose, turinčiuose citavimo rodiklį, trys - Clarivate Analytics Web of Science duomenų bazès „Conference Proceedings" leidiniuose ir du - kituose recenzuojamuose mokslo leidiniuose.

Disertacijos tema perskaityti pranešimai septyniose mokslinèse konferencijose Lietuvoje bei užsienyje:

- Tarptautinejje konferencijoje „iROS2017“ 2017 m., Vankuveryje, Kanadoje.

- Tarptautineje konferencijoje „Engineering and evolution of bio-hybrid societies" 2017 m., Grace, Austrijoje.

- Tarptautineje konferencijoje „4th IEEE Workshop on Advances in Information, Electronic and Electrical Engineering" 2016 m., Vilniuje, Lietuvoje. 
- Užsienio konferencijoje „From bio-inspired to bio-hybrid (robotic) systems “ 2016 m., Lozanoje, Šveicarijoje.

- Jaunujų mokslininkų konferencijose „Mokslas - Lietuvos ateitis“ 2014 ir $2015 \mathrm{~m}$. Vilniuje, Lietuvoje.

- Tarptautineje konferencijoje „ECT-2013: 8th international conference on electrical and control technologies " 2013 metais, Kaune, Lietuvoje.

2014 metais buvo dalyvauta "Myorobotics Winter School and Workshop“ žiemos mokykloje, Kembridže, Anglijoje. 2016 metais dalyvauta „From bioinspired to bio-hybrid (robotic) systems" žiemos mokykloje, Lozanoje, Šveicarijoje. 2016 metais buvo atlikta stažuotė Karlo III-ojo universitete, Madride, Ispanijoje. 2017 metais buvo dalyvauta ,Engineering and evolution of bio-hybrid societies" vasaros mokykloje. 2015-2016 metais laimèta Lietuvos mokslo tarybos finansuojama doktoranto stipendija už mokslinius pasiekimus.

\section{Disertacijos struktūra}

Disertaciją sudaro įvadas, trys skyriai ir bendrosios išvados.

Darbo apimtis yra 125 puslapiai, tekste panaudotos 96 numeruotos formulès, 47 paveikslai ir 16 lentelių. Ruošiant disertaciją buvo panaudoti 136 literatūros šaltiniai. 


\section{1}

\section{Mobiliujų robotų energijos sąnaudų analizè}

Skyriuje nagrinejjami vaikščiojantys robotai, jų tipai, klasès, konstrukcijos bei valdymo metodai. Nagrinèjamos energijos sąnaudu atsiradimo ir didejjimo priežastys, o taip pat energijos sąnaudų matavimo metodai, energijos sąnaudų skaičiavimo bei optimizavimo metodai taikomi ịvairiems mobiliems robotams. Skyriaus gale pateikiamos išvados ir tikslinami darbo uždaviniai.

Skyriaus tematika paskelbti du autoriaus straipsniai (M. Luneckas, T. Luneckas, D. Udris, N. M. F. Ferreira 2014; V. Valaitis, T. Luneckas, M. Luneckas, D. Udris 2015).

\subsection{Vaikščiojantys robotai ir jų energijos sąnaudos}

Vaikščiojantys robotai jau tyrinejjami apie 40 metų ir iki šiol yra sukurta nemažas kiekis įvairių tipų bei skirtingų konstrukcijų vaikščiojančių robotų, kurie skiriasi ne tik savo paskirtimi, bet ir valdymo būdu. Lyginant su važiuojančiais robotais, vaikščiojančiu robotų didžiausi privalumai yra universalumas, lankstumas bei galimybė judèti nelygiu paviršiumi (C. F. Juang et. al. 2015). Važiuojantiems robotams reikia lygaus paviršiaus, kad galètų judèti, tuo tarpu vaikščiojantys robotai judejjimui naudoja kojas (robotų kūrimas remiasi biologi- 
kūrimas remiasi biologiniais aspektais) (H. Kimura et. al. 2007, H. E. Daou et. al. 2013), todèl gali prisitaikyti prie praktiškai bet kokio paviršiaus. Dèl šių savybių vaikščiojantys robotai gali būti taikomi gelbejjimo operacijoms (D. Wei et. al. 2014, J. C. Arevalo et. al. 2014), išminavimui (T. S. Shih et. al. 2012), kroviniu gabenimui (Y. Geva et. al. 2014), planetiniu tyrimų (A. Omer et. al. 2014, J. C. Arevalo et. al. 2014) ar povandeninių darbų misijose (J. Y. Kim et. al. 2014, J. Y. Kim et. al. 2015).

Vaikščiojantys robotai yra kur kas sudètingesni mechanizmai nei važiuojantys ar vikšriniai robotai (G. C. Haynes et. al. 2012). Jie reikalauja itin patikimų valdymo metodų, kad būtų palaikomas pastovus judejjimo stabilumas (S. Parasuraman et. al. 2012), kojų ir paviršiaus sąlytis (L. Ding et. al. 2013), pasiekiamas reikiamas greitis (M. Li et. al. 2014) ir išlaikomos minimalios energijos sąnaudos (D. W. Marhefka et. al. 1997).

\subsubsection{Vaikščiojančių robotụ tipai ir jụ valdymo metodai}

Visi vaikščiojantys robotai gali būti grupuojami dviem būdais. Visų pirma jie gali būti grupuojami pagal kojų skaičių: dvikojus, trikojus, keturkojus, šešiakojus ir aštuonkojus (X. Y. S. Castro et. al. 2013). Keli dvikojų robotų pavyzdžiai gali būti „KHR-2“ robotas (J. H. Kim et. al. 2008), „ARMAR-IIIb“ robotas (Trovato et. al. 2015) arba „HRP-2“ dvikojis robotas (J. Ido et. al. 2009). Iš keturkojų robotų patys pažangiausiai iki šiol sukurti robotai yra Boston Dynamics kompanijai priklausantys „BigDog“ (D. Wooden et. al. 2010) arba „LittleDog“ robotai (A. Shkolnik et. al. 2011), taip pat Masačiusetso technologijos institutui priklausantis robotas gepardas „MIT Cheetah“ (D. J. Hyun et. al. 2016). Tarp šešiakojų ir aštuonkojų robotų pirmaujančių nėra, tačiau dažniau tyrinejjami šešiakojai robotai dèl paprastesnès konstrukcijos. Geri šešiakojų robotų pavyzdžiai galètų būti šie robotai: „Rhex“ šešiakojis (P. C. Lin et. al. 2006), „AMOS“ šešiakojis (Xiong et. al. 2015) arba Harvardo universiteto ambulatorinis šešiakojis mikro robotas (A. T. Baisch et. al. 2010). Vaikščiojančių robotų su skirtingu kojų skaičiumi pavyzdžiai pavaizduoti 1.1 paveiksle.

Kitas grupavimo būdas yra pagal kūno formą. Nuo kūno formos priklauso roboto kinematinis modelis, kuris nulemia judejjimo parametrus ir roboto stabilumą. Pavyzdžiui šešiakojų robotų kūno formos gali būti paprasto stačiakampio arba šešiakampio formos (X. Ding et. al. 2010, S. Long et. al. 2014). Dažniausiai šios formos būna konstruojamos taip, kad dešinioji ir kairioji pusès būtų simetriškos. Tuo atveju roboto valdymas yra paprastesnis. Tačiau kai kuriais atvejais roboto kūnas būna pilnai simetriškas: tiek dešinioji ir kairioji pusès yra simetriškos ir taip pat priekis ir galas yra simetriški; kūnas yra 
kvadrato arba taisyklingo šešiakampio formos (S. Long et. al. 2014). Kai kuriais atvejais roboto kūnas gali būti tiesiog taisyklingo apskritimo formos, kur kojos išdèstytos vienodais atstumais aplink ji (X. Ding et. al. 2010). Skirtingos kūnų formos ir galūnių kinematinis išdèstymas pavaizduoti 1.2 paveiksle. Tos pačios 9 kūno formos tinka ne tik šešiakojams, tačiau ir keturkojams, ir aštuonkojams robotams.

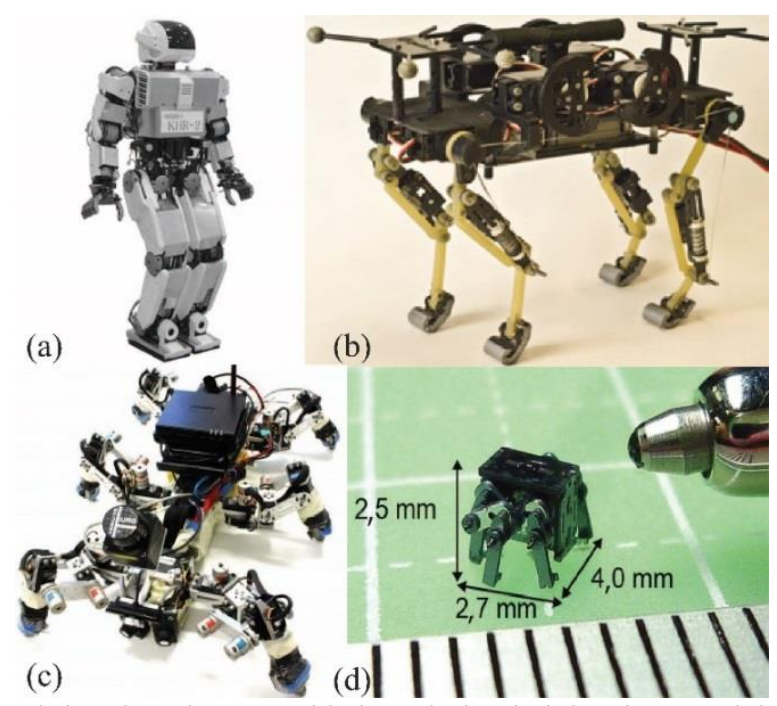

1.1 pav. Vaikščiojančių robotų su skirtingu kojų skaičiumi pavyzdžiai: (a) dvikojis „KHR-2“ robotas (J. Y. Kim et. al. 2009); (b) keturkojis „Cheetah-cub“ robotas (A. Sprowitz et. al. 2013); (c) šešiakojis „AMOS“ robotas (X. Xiong et. al. 2015); (d) šešiakojis mikro robotas (K. Saito et. al. 2012)

Fig. 1.1. Examples of walking robots with different number of legs: (a) biped "KHR-2" robot (J. Y. Kim et. al. 2009); (b) quadruped "Cheetah-cub" robot (A. Sprowitz et. al. 2013); (c) hexapod "AMOS" robot (X. Xiong et. al. 2015); (d) hexapod micro robot (K. Saito et. al. 2012)

Vaikščiojančių robotų judejimui naudojamas tam tikras kojų skaičius, todèl visų jų konstrukcija priklauso ir nuo kojų konstrukcijos. Visų vaikščiojančių robotu kojos skiriasi pagal laisvès laipsnių skaičių (LL), kuris nulemia roboto manevringumą. Dažniausiai vaikščiojantys robotai turi tris LL (Y. Go et. al. 2006, X. Ding et. al. 2010, G. Chen et. al. 2017) ant kiekvienos kojos. Kai kuriais atvejais būna robotų su dviem kiekvienos kojos LL (M. J. Spenko et. al. 2008). Žinoma, yra ir išimčių, kai roboto koja kuriama su vienu laisvès laipsniu (P. C. Lin et. al. 2006) arba labai išskirtiniais atvejais, kai koja sudaroma net iš keturių arba daugiau laisvès laipsnių. Tokie atvejai dažniausiai pasitaiko kuriant įvairius žmogiškuosius dvikojus robotus, kurie reikalauja itin didelio lankstumo 
(L. C. Macias et. al. 2017). Keičiant LL skaičių ir kojos konfigūraciją (kojos sąnarių išdèstymą) galima gauti daug skirtingų variacijų, kurios nulems, kaip kokybiškai ir greitai robotas gebès judèti lygiu ar nelygiu paviršiumi ir kaip gebès išvengti kliūčių.

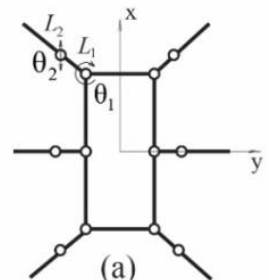

(a)

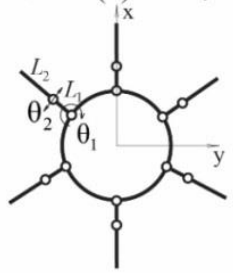

(d)

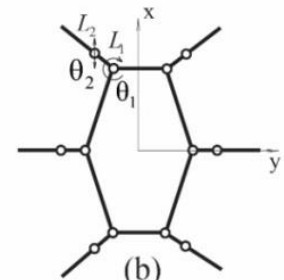

(b)

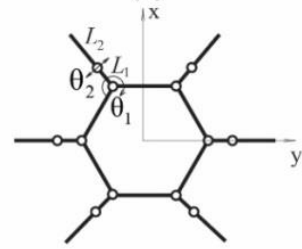

(e)

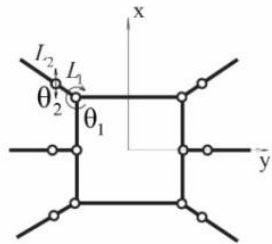

(c)

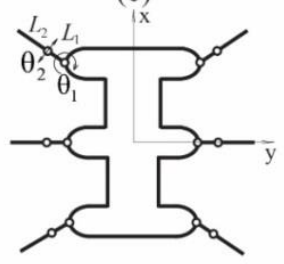

(f)

1.2 pav. Skirtingas šešiakojų robotų kūnų kinematinis išdèstymas: (a) stačiakampis;

(b) šešiakampis; (c) taisyklingas kvadratas; (d) taisyklingos formos apskritimas; (e) taisyklingas šešiakampis; (f) beformis

Fig. 1.2. Different types of hexapod robot body kinematic layout: (a) rectangular; (b) hexagonal; (c) symmetrical square; (d) symmetrical circle; (e) symmetrical hexagon;

(f) shapeless form

LL skaičius gali būti didinamas ne vien pavarų skaičiumi kojose, bet ir keičiant pavarų skaičių ant roboto kūno (Y. Tang et. al. 2015, S. Wang et. al. 2014). Taikant tokị metodą galima mažinti kojų LL skaičių, nes kūno judejjimas kompensuoja kojų judèjimo laisvę. Naudojant tokị metodą, reikia taikyti šiek tiek kitokị roboto valdymą, kuris skiriasi nuo ịprastinio atvirkštinès kinematikos uždavinio, o taip pat roboto konstrukcija tampa sudetingesnè.

Nepriklausomai nuo roboto kūno ir kojų konstrukcijos, ị roboto valdymo sistemą turi būti įdiegtas valdymo algoritmas, pagal kurị robotas atliks užprogramuotus veiksmus. Norint valdyti tokias sudètingas sistemas, sudarytas iš didelio pavarų skaičiaus, ir pasiekti universalų vaikščiojimą dažniausiai naudojami šie metodai: tiesioginès ir atvirkštinès kinematikos metodai (C. Runbin et. al. 2013, G. Xin et. al. 2015), kai sudaromos roboto kojų jungiamųu dalių kampų priklausomybès nuo norimų pėdų koordinačių, bei dinamikos ir atvirkštinès dinamikos metodai (S. Ali et. al. 2010, A. Mahapatra et. al. 2015), kai sudaromos kojų pėdų galinių taškų greičių priklausomybès nuo jungiamujų dalių kampinių greičių. Siekiant padidinti 
roboto pėdų paděčių ir pėdos trajektorijos generavimo tikslumą dažnai taikomas proporcinis-integralinis-diferencialinis (PID) metodas ar jo variacijos (I. Kesckes et. al. 2014). Tokio metodo esmè yra priartinti gaunamus atvirkštinès kinematikos ar dinamikos metodų būdu skaičiuojamus kampus/greičius prie norimų teorinių skaičiavimų. Teisingai konfigūruojant PID valdymą galima pasiekti pakankamai aukšto tikslumo rezultatus.

Kitas plačiai tyrinèjamas vaikščiojančių robotų valdymo būdas yra centrinis struktūros generatorius (angl. central pattern generator (CPG)). Toks metodas buvo pastebètas gamtoje (pvz. vabzdžių judejjime) ir plačiai taikomas robotų judejjimo valdymui (J. H. B. Zambrano et. al. 2012, X. Wu et. al. 2013) ar judejjimui per nelygų paviršių (C. Weihai et. al. 2014). Šio metodo esmè yra kurti valdymo signalus konkrečioms roboto galūnèms ar net sąnariams, tokiu būdu išskaidant bendrą roboto valdymą i atskiras dalis. Tačiau centrinio struktūros generatoriaus metodas nèra pilnai išvystytas ir reikalauja gilesnio nagrinëjimo iki kol jis bus pilnai taikomas vaikščiojantiems robotams.

Taip pat populiarus valdymo metodas yra neraiškioji logika (angl. fuzzy logic). Šis metodas gali būti taikomas ne tik robotikos problemoms spręsti ir yra labai universalus. Neraiškioji logika gali būti taikoma roboto judejjimui pagerinti nepakeičiant stabilumo (I. Kesckes et. al. 2014, C. F. Juang et. al. 2015, R. K. Barai et. al. 2008), judejjimui nuožulniais šlaitais tiek daugiakojams robotams, tiek dvikojams (C. Zhou 2000, U. Seven et. al. 2012, W. J. Wang et. al. 2017), adaptyviam judejjimui per skirtingus paviršius (Z. Y. Guang et. al. 2015), kliūčių išvengimui ir orientavimuisi aplinkoje (Y. H. Chou et. al. 2002), taip pat kitose srityse. Neraiškiosios logikos metodas leidžia parinkti tinkamiausias parametrų vertes jas derinant tarpusavyje ir sudarant elgesio taisykles. Deja, norint taikyti dideli parametrų skaičių ar didelị kiekvieno parametro verčių skaičių, stipriai didejja taisyklių kiekis, todẻl roboto elgesys tampa paremtas kraštutinumais (roboto elgesys tampa nepastovus).

Nestabilus judëjimas yra viena iš svarbiausių vaikščiojančių robotų problemų, ypač dvikojams robotams (W. Yang et. al. 2013, F. Ali et. al. 2013). Neišlaikant stabilumo vaikščiojimas yra neįmanomas. Šiai problemai spręsti dažnai naudojamas nulinio momento taško metodas (angl. zero moment point (ZMP)) (R. Xin et. al. 2009, V. Antoska et. al. 2013). Tai toks taškas ant paviršiaus, kuriame momentai aplink dvi susidariusias ašis yra lygūs nuliui. Stabilumo kriterijus pagal nulinio momento taško metodą sako, kad jei nulinio momento taškas yra palaikymo daugiakampyje, dinamiškai stabilus judejjimas yra garantuotas (A. Massah et. al. 2013). Toks metodas gali būti taikomas visiems daugiakojams robotams, tačiau nèra būtinas robotams, kurie turi šešias ar daugiau kojų, nes ant paviršiaus visada yra trys arba daugiau kojų.

Vaikščiojantiems robotams taip pat būtinas judejjimo algoritmas, pagal kurị bus nustatoma, kokiu eiliškumu robotas perkels kojas. Kojų perkèlimo 
eiliškumas yra vadinamas eisena (angl. gait). Dauguma vaikščiojančių robotų eisenų kuriama pagal gamtoje esančius judejimo būdus: dvikojams ir keturkojams robotams atkartojant žmones ir kitus gyvūnus (H. Kimura et. al. 2007, C. Ferreira et. al. 2017), šešiakojams robotams - vabzdžius (M. Schilling et. al. 2007, K. Mostafa et. al. 2015). Pagrindinès eisenos keturkojams robotams yra ejjimas, žingsniavimas, risnojimas ir šuoliavimas (X. Zhiang et. al. 2006, C. Rungin et. al. 2013, A. Sprowitz et. al. 2013). Šešiakojų pagrindinès eisenos yra trys: trikojè, dvikojè ir banguojanti (M. R. Fielding et. al. 2004, W. Chen et. al. 2012). Robotai, judėdami šiomis eisenomis, gali pasiekti plačiausią greičių diapazoną ir mažiausias energijos sąnaudas.

Nors eisenos yra tinkamas metodas judant pakankamai paprastais ir lygiais paviršiais, judèjimui nelygiais ar sudètingais paviršiais jos gali būti sunkiai pritaikomos. Tokiu atveju tinkamesnis judejimo metodas yra kojų pédų koordinačiu planavimo metodas (angl. footplanner method) (K. Hauser et. al. 2008). Šio metodo esmé yra sugeneruoti koordinates kiekvienai roboto pèdai atskirai ir pritaikyti rezultatus generuojant nuoseklų ejimą (savotišką eiseną). Tada kiekviena koja bus pastatoma ant paviršiaus nepriklausomai nuo jo nelygumo. Lyginant su eisenomis, pejdų pastatymo planavimo metodas yra itin lètas, nes atliekami skaičiavimai kiekvienam žingsniui viso judejjimo metu.

Tiek judejjimas naudojant skirtingas eisenas, tiek kojų pėdų pozicionavimo planavimas priklauso nuo kojų ir jų LL skaičiaus. Kartais gali nutikti taip, kad kuri nors jungiamoji dalis nustos dirbti (suges, nulūš arba negaus pakankamo energijos kiekio). Taip nutikus roboto judejjimas gali pasikeisti arba sustoti. Šiai problemai spręsti taikomas klaidai tolerantiškos eisenos metodas (angl. fault tolerant gait) (U. Asif 2012), kuris leidžia sukurti ir pritaikyti naujas eisenas judejjimui lygiu ir nelygiu paviršiumi ịvykus pavaros ar jutiklio gedimui. Panašus metodas, skirtas judejjimui nenumatytomis sąlygomis, kai sugenda tam tikros roboto detalès, yra T-atsparumo metodas (angl. T-resilience) (S. Koos et. al. 2013). Šis metodas nèra skirtas nustatyti sugedusioms dalims, tačiau leidžia savarankiškai ir efektyviai rasti elgseną, kai sugedusi dalis nèra reikalinga. Žinoma, šie metodai dar yra tik pirminès versijos roboto judejjime esant gedimams, todèl nèra pilnai sukurti ir veikia tik tam tikromis sąlygomis.

Robotams būdinga taikyti tokius valdymo metodus, kurie dažnai sutinkami ir gyvoje gamtoje. Vienas tokių būtų yra dirbtinių neuronų tinklas (angl. neural network) (K. Saito et. al. 2012). Šis metodas nèra paprastas ir reikalauja daug laiko tinkamai sukonfigūruoti, kad gerai veiktų, tačiau gali būti labai plačiai taikomas sprendžiant ịvairias robotų valdymo ar judejjimo problemas. Viena iš dažnų neuroninių tinklų taikymo sričių yra roboto judejjimo eisenų mokymas (C. F. Juang et. al. 2011). Robotas išmoksta pasirinkti sau tinkamiausią eiseną, todèl nereikalinga žmogaus pagalba. Neuroninius tinklus taip pat praktiška taikyti 
planuojant robotų judèjimą (S. Yildirim 2008), gerinant judèjimo tikslumą (Y. Lin et. al. 1997) arba pavaru valdymo tikslumą (J. Santos et. al. 2017), tačiau toks būdas yra žinomas kaip labai lètas procesas ir reikalauja daugelio bandymų. Kai kuriais atvejais dirbtinių neuronų tinklai taikomi kaip virtualūs jutikliai, siekiant apmokyti robotą teisingai suprasti iš jutiklių gautą informaciją (J. Estremera et. al. 2005). Kitas būdas taikyti dirbtinius virtualius neuroninius tinklus yra biologinių principų imitavimas siekiant suprasti, pvz. vabzdžių, judejjimą ir elgseną (M. Schilling et. al. 2013). Toks neuroninių tinklų pritaikymas leidžia geriau suprasti gamtoje naudojamus gyvujų organizmų judejjimo ir prisitaikymo principus, kurie vẻliau tampa naudingi vaikščiojančių robotų kūryboje ir valdyme. Tačiau visi metodai susiję su neuroniniais tinklais veikia labai lètai, todèl juos sunku pritaikyti roboto veikimui realiu laiku.

Vaikščiojančių robotų kūryboje dažnai naudojami ir jègos jutikliai, kurie yra būtini kontroliuojant roboto pedų sąlytị su paviršiumi (L. Ding et. al. 2013). Naudojant jègos jutiklius taip pat galima valdyti ir roboto judejimą per nelygu paviršių (S. Kaliyamoorthy et. al. 2005) ar siekiant išlaikyti visapusišką stabilumą (M. Agheli et. al. 2016). Vienintelis sunkumas, susijęs su jègos jutikliais, yra jų integravimas ant roboto pèdų. Jègos jutikliai dažniausiai yra ploni ir jautrūs, todèl montuoti juos reikia itin saugiai, o taip pat kiekvienas robotas yra unikalus ir jutiklių montavimas gali stipriai skirtis.

Lyginant visus aptartus robotų valdymo metodus matyti, kad pagrindinis panašumas tarp jų yra lètas veikimas. Dauguma minètų metodų reikalauja daug laiko, kad būtų atlikti skaičiavimai, todèl dažniausiai skaičiavimai atliekami ne realiu laiku, o prieš roboto veikimą. Tai yra trūkumas, nes metodai negali būti taikomi robotui veikiant realiu laiku, nes robotas juda greičiau nei priima sprendimą ir todèl gali nespèti atlikti reikiamų veiksmų. Kitas pastebimas trūkumas yra metodų tarpusavio nesusietumas. Nors kiekvienas metodas atskirai yra universalus, tačiau tarpusavyje jie sunkiai gali būti suderinti, kad veiktų kaip vienas. Tai neleidžia praplèsti robotų valdymo galimybių, o tik pritaikyti juos konkretiems atvejams. Apibendrinant galima teigti, kad trūksta bendresnių metodų, kurių taikymas leistų derinti daugiau roboto savybių ir parametrų.

\subsubsection{Vaikščiojančių robotų mažo energetinio efektyvumo priežastys}

Nepaisant didelių vaikščiojančių robotų privalumų judant nelygiu paviršiumi, prisitaikant prie aplinkos bei plačių šių robotų taikymo galimybių, konstruojant tokias autonomines sistemas susiduriama su problemomis, kurias būtina išspręsti norint panaudoti vaikščiojančius robotus realiose užduotyse. Savarankiškos užduotys reikalauja ilgo darbo laiko, todèl viena iš svarbiausių autonominių 
vaikščiojančių robotų problemų tampa didelès energijos sąnaudos (H. P. Siregar 2005, A. Roennau et. al. 2011).

Yra daug priežasčiu, kodèl vaikščiojantys robotai pasižymi didelèmis energijos sąnaudomis. Viena iš dažniausiai sutinkamų priežasčių yra didelis pavaru skaičius (G. C. Haynes et. al. 2012, X. Xiong et. al. 2015). Iprastai dvikojai, keturkojai ir šešiakojai robotai turi nuo 12 iki 24 ar net daugiau LL, o kiekvienas LL kuriamas montuojant papildomą elektros pavarą (arba hidraulinę, jei robotas yra itin didelis). Robotai, turintys mažesnị LL skaičių nepasižymi tokiu geru lankstumu lyginant su robotais, kurie turi didesnị LL skaičių.

Kita priežastis didelèms energijos sąnaudoms atsirasti yra didelis roboto svoris. Visi vaikščiojantys robotai turi nešti ne tik savo kūno konstrukciją, tačiau ir visas pavaras, valdymo sistemą ir net energijos šaltinị (D. C. Kar et. al. 2001). Iprastai vaikščiojantys robotai gali sverti nuo kelių iki keliasdešimties kilogramų (S. Bartsch et. al. 2012, R. Zhang et. al. 2013, X. Xiong et. al. 2015) (kartais ir iki kelių tonų (A. Irawan et. al. 2011)). Net kai kurie mikro robotai, kurie sveria vos kelis gramus, pagal savo dydi suvartoja didelị energijos kiekị (P. Birkmeyer et. al. 2009, N. J. Kohut et. al. 2011).

Nors valdymo schemos elektronikos komponentai suvartoja sąlyginai mažą energijos kiekị, didelis jų skaičius gali stipriai ịtakoti bendrą roboto energetiką. Kaip yra žinoma, dauguma vaikščiojančių robotų turi veikti savarankiškai be žmogaus ịsikišimo, todèl tokiam darbo režimui būtina aprūpinti robotą ịvairiais jutikliais ir vykdikliais, kad jis galetuc laisvai orientuotis aplinkoje, tinkamai priimti sprendimą arba tikslingai atlikti mokslinius tyrimus (L. Minati et. al. 2002). Taip pat reiktų atkreipti demesị ir ị tai, kad iš kuo daugiau komponentų sudarytas robotas, tuo daugiau atsiranda galimybių gedimams ir didesnę ịtaką daro detaliu nusidèvëjimas. Kai tam tikros detalès nusidèvi (pvz. pavaros ar jutikliai), roboto judejimui pasidaro reikalingas didesnis energijos kiekis siekiant išlaikyti nepakeistą judejjimą (X. Wu et. al. 2011).

Dar viena didelių energijos sąnaudų priežastis yra ịvairūs sąlyčiai su paviršiumi judant nelygiu paviršiumi, atsitrenkimai ị aplinkoje esančias kliūtis (Z. G. Zhang et. al. 2006), o taip pat šiluminiai nuostoliai pavarose ar valdymo sistemoje veikiant intensyviu darbo režimo metu (T. Okada et. al. 2010), trintis ar tamprumas (A. T. Baisch et. al. 2014).

\subsection{Robotų energijos sąnaudų matavimo ir skaičiavimo metodai}

Norint įvertinti roboto energijos sąnaudas reikia taikyti vieną iš energijos sąnaudų matavimo ir skaičiavimo metodų. Tokių metodų yra palyginti nedaug ir jie yra pakankamai paprasti. 
Pats paprasčiausias ir dažniausiai naudojamas energijos sąnaudų matavimo metodas yra robotui tenkančio elektros srovès stiprio matavimas judejjimo metu (A. Roennau et. al. 2011). Energijos sąnaudos labiausiai susijusios su pavarų energijos sąnaudomis (S. S. Roy et. al. 2011), todèl dažniausiai stebimas būtent pavaroms tenkantis elektros srovès stipris. Šaltinio įtampos kitimą taip pat galima stebèti, taigi energiją galima apskaičiuoti kaip galios kitimą laike (P. G. de Santos et. al. 2009, S. S. Roy et. al. 2014):

$$
E=\int u(t) \cdot i(t) d t,
$$

čia $E$ - bendras sistemos suvartojamas energijos kiekis, $u(t)$ - maitinimo šaltinio itampa, $i(t)$ - iš šaltinio tekančios elektros srovès stipris, $t$ - laikas.

Valdymo sistemos suvartojama energija ịprastai būna tokia maža, kad i (1.2.1) formulę ji nèra ịskaičiuojama, nebent tai būtų mikro robotas, kurio pavarų ir kitų elektronikos komponentų suvartojamas energijos kiekis yra artimas.

Pagal (1.1) formulę gautas roboto suvartojamas energijos kiekis nieko nepasako apie jo energetini efektyvumą. Perskaičiuojant energijos kieki i transportavimo kaštų parametrą (angl. cost of transport (COT)) galima gauti roboto suvartojamos energijos kiekio ar galios santyki su jo mase bei judejjimo greičiu arba nueitu atstumu:

$$
C O T=\frac{E}{m g d}=\frac{P}{m g v},
$$

čia $E$ - bendra sistemos suvartota energija, $P$ - suvartojama galia, $m$ - sistemos mase (ịskaitant papildomą krovinį), $g$ - laisvojo kritimo pagreitis, $d$ - roboto nueitas kelias, $v$ - roboto judejjimo greitis.

Transportavimo kaštai parodo, kiek energijos reikia suvartoti, norint nugabenti tam tikros masès kūną, tam tikru atstumu arba kokia galia reikalinga tam tikros masès kūnui judèti tam tikru greičiu. Todėl toks metodas yra taikomas labai plačiai: gyvūnų, vabzdžių, automobilių, paukščių, žuvų, didesnių mobiliujų robotu (J. Nishii 1998, A. G. G. Rodriguez et. al. 2014) bei mikro robotu (P. Birkmeyer et. al. 2009, A. T. Baisch et. al. 2014) energetinio efektyvumo skaičiavimui. Kai kuriuose šaltiniuose transportavimo kaštai dar vadinami „specifine varža“ (B. S. Lin et. al. 2001, U. Saranli et. al. 2001, P. Arena et. al. 2006, D. S. Merodio et. al. 2012) arba mechaniniais transportavimo kaštais (angl. mechanical cost of transport (cmt)) (O. S. Kwon et. al. 2012) ir skaičiuojamas pagal tokią pačią formulę kaip (1.2).

Kitas būdas energijos sąnaudoms ịvertinti yra mechaninis metodas, kai matuojami visų LL (pavarų) momentai (F. Yamasaki et. al. 2002, A. C. Amran et. al. 2013). Mechaninę galią apskaičiuoti galima integruojant 
pavaros momento ir sąnario kampinio greičio sandaugą (J. Estremera et. al. 2008):

$$
W=\int_{t=0}^{t=T} \tau(t) \cdot \omega(t) d t,
$$

čia $\tau(t)$ - LL momentas, $\omega(t)$ - LL kampinis greitis, $t$ - laikas, $T$ - kojos ciklo periodas.

Kaip matyti iš šaltinio (J. Estremera et. al. 2008), tiek mechaninè, tiek elektriné energijos sutampa, jei pavarų naudingumo koeficientas prilyginamas 1 , todèl formulių (1.1) ir (1.3) dešiniosios pusès yra lygios, todèl:

$$
E=\int u(t) \cdot i(t) d t=\int \tau(t) \cdot \omega(t) d t .
$$

Kai kuriose dinaminèse sistemose yra naudojami tiesiaeigiai varikliai ar pavaros, todèl sukamojo momento tokiose sistemose nèra ir energijos skaičiavimas pagal (1.4) formulę yra netinkamas. Tokiu atveju pilnutinę pavaros energiją galima apskaičiuoti integruojant veikiančios jègos ir fiksuoto taško koordinatės sandaugą (B. Vanderborght et. al. 2009):

$$
E=\int|F \cdot x| d t,
$$

čia $E$ - linijinès pavaros energija, $F$ - tašką veikianti jèga, $x$ - fiksuoto taško koordinatè, $t$ - laikas.

Dar vienas metodas energijos sąnaudų matavimui yra kinetinès energijos skaičiavimas. Daugumai robotų naudojamos sukamojo judesio pavaros, todèl kinetinę pavaros energiją galima apskaičiuoti pagal pavaros inercijos ir kampinio greičio sandaugą (S. Kim et. al. 2006):

$$
E_{k}=\frac{1}{2} I \cdot \omega^{2},
$$

čia $E_{k}$ - vienos pavaros kinetinè energija, $I$ - pavaros inercija, $\omega$ - kampinis pavaros greitis.

Kai kuriais atvejais vien kinetinès energijos ịvertinimo neužtenka, todèl yra skaičiuojama ir potencinè sistemos energija. Vieno LL potencinę energiją galima apskaičiuoti kaip tos dalies masės, masès centro taško aukščio ir laisvojo kritimo pagreičio sandaugą (Z. Wang et. al. 2011):

$$
E_{p}=m \cdot g \cdot h,
$$

čia $E_{p}$ - vienos pavaros potencinè energija, $m$ - pavaros masè, $g$ - Žemès traukos pagreitis, $h$ - pavaros masès centro taško aukštis.

Tiek kinetinès energijos išraiška (1.6), tiek potencinès energijos išraiška (1.7) yra pateiktos vienam roboto LL. Robotikoje visada reikalinga sistemos pilnutiné energija, kuri susideda iš visų jungiamujų dalių suvartojamos energijos kiekio. Žinant tai, pastarąsias išraiškas galima perrašyti taip: 


$$
\begin{aligned}
& E=\sum_{i=1}^{N} \frac{1}{2} I_{i} \cdot \omega_{i}^{2}, \\
& E=\sum_{i=1}^{N} m_{i} \cdot g \cdot h_{i},
\end{aligned}
$$

čia $E$ - pilnutinè sistemos energija, $I_{i}-i$-tojo roboto LL inercija, $\omega_{i}-i$-tojo LL kampinis greitis, $m_{i}-i$-tojo LL masè, $g-$ Žemès traukos pagreitis, $h_{i}-i$-tojo LL masès centro aukštis, $N$ - LL skaičius.

Tarpusavyje energijos matavimo ir skaičiavimo metodai nesusiję, nes kiekvienas metodas reikalauja skirtingų matavimo priemonių ir skaičiavimo parametrų. Apibendrinus, suvartojamos energijos matavimo metodas priklauso nuo roboto konstrukcijos. Jei robotas maitinamas iš elektros srovès šaltinio ir yra galimybe pamatuoti šiuos parametrus, gali būti taikomi elektros srovès stiprio matavimo metodai. Jie pasižymi tikslumu ir paprastumu, nes šaltinio įtampos kitimą taip pat galima išmatuoti, o daugiausia kinta tik elektros srovès stipris ir laikas - lengvai išmatuojami dydžiai. Jei tiesioginių energijos sąnaudų išmatuoti nèra įmanoma, tenka taikyti energijos įvertinimo metodus, susijusius su jègų ir momentų matavimu. Šie metodai taip pat yra pakankamai tikslūs, tačiau nèra galimybès įvertinti roboto valdymo sistemos suvartojamos energijos kiekio.

\subsection{Energijos sąnaudų minimizavimo metodai}

Iki šiol jau buvo atliktas nemažas kiekis tyrimų siekiant minimizuoti robotų energijos sąnaudas ar optimizuoti judejjimą, kad būtų suvartojamas minimalus energijos kiekis. Tai daroma tam, kad robotų (ypač vaikščiojančių) darbo laikas būtų kuo didesnis, nes autonomiškumas reikalauja pakankamai didelio energijos rezervo. Kitu atveju robotai bus nepajègūs atlikti jiems užduotų darbų ar tyrimų arba darbo metu išsijungs nebaigę užduoties.

Idealiu atveju, robotui judant lygiu horizontaliu paviršiumi, jègos ir greičio kryptys nesutampa ir dèl to robotas turètų suvartoti labai mažą energijos kiekị (tik judejjimo impulsui sukurti). Tačiau iš tikrujų yra žinoma, kad net ir judant lygiu paviršiumi robotai vartoja energiją (K. Yoneda et. al. 2003). Tai susiję su trintimi, oro pasipriešinimu, energijos keitimo nuostoliais ir panašaus pobūdžio priežastimis, tačiau patvirtina, kad energijos sąnaudų minimizavimas vaikščiojantiems robotams yra aktualus uždavinys.

Vienas iš žinomų metodų minimizuoti roboto energijos sąnaudas yra tinkamas jègu paskirstymas roboto pėdose, kad visos pavaros vartotų minimalų energijos kieki (D. W. Marhefka et. al. 1998). Tokiame metode ịskaitytas vidinių jègų minimizavimas, jungiamujų dalių momentų minimizavimas ir sistemos galios minimizavimas ir yra sprendžiamas taikant atitinkamas 
optimizavimo metodus. Tačiau šis metodas nèra visapusiškai geras, nes tais atvejais, kai roboto judejjimas yra pagrįstas ribinèmis vertėmis (pvz. maksimalus kojos aukštis, pèdos koordinatė neatitinka roboto kojos darbo zonos), užprogramuotos funkcijos duoda priešingą rezultatą (gali būti gaunama begalinė parametro vertè).

Energijos sąnaudų minimizavimui taip pat aktualu roboto konstrukcija. Mažinant konstrukcinių detalių ir pavarų skaičių arba keičiant jas tam tikromis kitomis lengvesnèmis dalimis mažèja roboto masė (D. W. Marhefka et. al. 1998). Kaip buvo nagrinèta 1.2 poskyryje, energijos sąnaudos stipriai priklauso nuo viso roboto masès, todèl, minimizuojant roboto konstrukciją galima pasiekti teigiamų rezultatų. Vienas iš vaikščiojančių robotų pavyzdžių, kur robotas konstruojamas naudojant minimalų pavarų skaičių ir detalès parenkamos mažesnio tankio medžiagos (pvz. titanas, aliuminis, plastikas, silikonas, guma) yra „Rhex“ šešiakojis robotas, kuris turi tik šešias pavaras (U. Saranli et. al. 2001, J. D. Weingarten et. al. 2004). Tačiau ne visais atvejais tinka naudoti mažą pavarų skaičių, nes nuo to priklauso LL skaičius ir roboto lankstumas. Taip pat ir mažesnio tankio medžiagos ne visada yra tinkamos. Kai kuriais atvejais robotas turès kelti/nešti sunkius daiktus ar tvirtai ịsikibti ị paviršių, todèl yra didele tikimybė, kad elastingos ir lengvos medžiagos greitai skils ar lūš, todèl ịvyks roboto gedimas.

Panašus eksperimentas mažinant roboto pavarų skaičių ir renkantis tik energetiškai efektyvius elektronikos komponentus buvo atliktas su „Ranger“" robotu, kuris turi tik penkias pavaras (P. A. Bhounsule et. al. 2014). Šis robotas vienu akumuliatorių baterijos ịkrovimu nuejjo net $65 \mathrm{~km}$ atstumą per 31 val. Toks rezultatas buvo pasiektas ne vien mažinant pavarų skaičių, bet ir atliekant judejjimo trajektorijos optimizavimą matematinio modeliavimo aplinkoje ne realiu laiku. Buvo pasiekta, kad didžiają dalị energijos suvartoja ne pavaros, o jutikliai ir kiti elektronikos komponentai bei mechaninis darbas.

Pavarų skaičių galima mažinti iki nulio. Tokie robotai egzistuoja ir jie vadinami pasyviais vaikščiotojais (angl. passive walkers). Tai yra robotai, kurie neturi nei valdymo sistemos, nei pavarų, nei jutiklių. Būtent dèl šių priežasčių jie pasižymi itin dideliu energetiniu efektyvumu (D. G. E. Hobbelen et. al. 2008). Tačiau neturint nei vienos pavaros, judèjimui sukurti būtina nuožulni plokštuma, ir tokie robotai negeba kompensuoti išorinių veiksnių, tokių kaip oro pasipriešinimo, vejjo, ịvairių trikdymų. Taigi tai rodo, kad sukurti robotus be pavarų yra itin sudėtingas uždavinys.

Kitas energijos sąnaudų minimizavimo būdas yra pateiktas šaltinyje (R. J. Lock et. al. 2009). Čia rašoma, kaip atlikti roboto kūrimo optimizavimą atliekant ịdemius pasyvaus stabilumo ir aktyvaus vaikščiojimo atsižvelgiant $\mathfrak{i}$ energijos sąnaudas stebejjimus. Šio metodo privalumas yra tai, kad energijos sąnaudos yra ịvertinamos dar prieš konstruojant robotą. Yra numatoma, kaip kis 
energijos sąnaudos keičiantis roboto stabilumui bei judejjimo parametrams. Nèra pilnai įmanoma ịvertinti visus veiksnius ir pokyčius bei sąryšius su išorinėmis jègomis, todèl šis metodas yra tik dalinai veiksmingas.

Kaip jau žinoma, vaikščiojančių robotų energijos sąnaudos atsiranda dèl didelio pavarų skaičiaus lyginant su važiuojančiais robotais. Taigi konstruojant ratus ant roboto pẻdų galima gauti pusiau važiuojantị, pusiau vaikščiojantị robotą. Toks metodas buvo išbandytas ant Cassino šešiakojo roboto (G. Carbone et. al. 2008). Parenkant tinkamą kojų konfigūraciją, vaikščiojantis robotas gali elgtis kaip važiuojantis ir judant lygiu paviršiumi tokiu būdu pasiekiamas didelis energetinis efektyvumas. Pagrindine šio metodo savybė yra universalumas (robotas gali elgtis kaip dviejų skirtingų rūšių robotai). Tačiau iš tikrujų toks robotas nèra pilnai nei važiuojantis, nei vaikščiojantis ir negali turèti visų vienos ar kitos rūšies privalumų.

Energijos sąnaudas taip pat galima minimizuoti kuriant robotus, panašius i biologinius organizmus. Tai yra patogu todèl, kad gamtoje gyvūnai ir vabzdžiai išsiugde idealius judejimo ir prisitaikymo metodus, kurie puikiai padeda jiems išgyventi. Norint pilnai nukopijuoti gyvūnus ar vabzdžius, reikalingas didelis pavarų skaičius ir sudètingas valdymo algoritmas, kad būtų gautas toks pat roboto lankstumas ir prisitaikymas. Tačiau tokiu būdu kuriami robotai turi itin didelị LL skaičiu, kurio jie nesugeba optimaliai kontroliuoti, o didelis pavarų skaičius lemia dideles energijos sąnaudas (M. F. Silva et. al. 2011).

Konstrukcijos atžvilgiu energijos sąnaudų minimizavimui stipriai padeda ir konstrukcinių detalių keitimas i elastingas medžiagas, pvz. kojas, kojų jungiamąsias dalis keičiant spyruoklèmis ir panašiai (J. Ackerman et. al. 2011). Naudojant elastingas medžiagas roboto masę, kurią gali sudaryti elektronikos, baterijos ir kūno masè, judèjimo metu galima kompensuoti tamprumu (J. Ackerman et. al. 2013). Žinoma, tokių medžiagų naudojimas padaro robotinę sistemą mechaniškai sudètingesne, didejja būtinų detalių skaičius, todèl didèja ir roboto masè.

Yra žinoma, kad palaikymo fazė yra labiausiai energetiškai nuostolingas etapas eisenos metu. Todèl energijos sąnaudos tampa susijusios ir su vaikščiojančių robotų kojų konfigūracija (T. Zielinska 2015). Priklausomai nuo kojos dalių ilgių, galimų žingsnio ilgių, stovésenos, kūno pakèlimo aukščio, keičiasi suvartojamas roboto energijos kiekis. Taigi keičiant roboto kojos konstrukciją galima sumažinti suvartojamą energijos kiekị. Toks metodas yra gana paprastas ir nereikalauja papildomų priemonių (jutiklių, pavarų), tačiau reikalauja papildomų skaičiavimo ir optimizavimo metodų, kurie leistų rasti tinkamiausias konfigūracijas.

Roboto darbo laiką praplèsti galima ne vien minimizuojant energijos sąnaudas, bet sudarant papildomą valdymo algoritmą roboto grịzimui ịkrauti bateriją arba ją pasikeisti kita (J. Wu et. al. 2012). Toks metodas reikalauja 
¡̨krovimo stotelès, stumdymo mechanizmo ir užrakinimo mechanizmo. Privalumas yra tai, kad roboto tipas nèra svarbus: gali būti važiuojantis, vikšrinis, vaikščiojantis. Kad vyktų tikslesnis roboto prisišvartavimas prie aptarnavimo stotelès, roboto priekyje montuojama kamera, o baterija yra lengvai atjungiama ir pritaisyta taip pat roboto priekyje. Šio metodo rezultatai rodo, kad visa baterijos keitimo operacija trunka $\sim 84$ sekundes ir tai reiškia, kad robotui nereikia laukti keliu valandų, kol baterija bus pilnai įkrauta. Toks metodas stipriai prailgina roboto veikimo laiką ir nereikalauja didelio žmogaus ịsikišimo ị roboto darbą.

Panašus metodas roboto ịkrovimui buvo sukurtas mokslininkų G. Parker ir R. Zbeda, kurie pasiūlè pritaikyti genetini algoritmą, kuris leistų robotui rasti informaciją, susijusią su baterijos įkrovimu. Gautą informaciją robotas pritaiko rasti baterijos ịkrovimo stotelę ir grịžti ì ją (G. Parger et. al. 2014). Robotas aprūpintas didelès talpos kondensatoriais, kad užtikrintų maksimalų efektyvumą. Tačiau pagrindinis tokio metodo trūkumas yra tai, kad sunku nustatyti ribą, kiek laiko robotas turi dirbti, o kada jau nutraukti darbą ir judèti link ịkrovimo stotelès, kad likusios energijos užtektų nukeliauti iki įkrovimo stotelès. Tačiau genetinis algoritmas stipriai pagerina visą metodo veikimą ir rodo, kad jo pritaikymas gali duodi teigiamų rezultatų.

Yra ir kitų būdų kaip prailginti roboto darbo laiką. Pavyzdžiui, mokslininkai Y. He, Z. You ir X. Wang pasiūlè patobulinti hibridinę energijos sistemą (HES), kuri realiu laiku kaupia ir tiekia saulès energiją robotui (Y. He et. al. 2013). Sistemos struktūra yra sąlyginai paprasta; jai reikalinga saulès baterija, pjezoelektrinis generatorius, ličio jonų baterija ir superkondensatorius. Tinkamai sudarius elektrines principines schemas galima sukonstruoti pagerintą iprastos energijos sistemos variantą. Tokiam metodui realizuoti nereikia tobulinti roboto valdymo programos ar įdiegti papildomų skaičiavimo metodų.

Nenaudojant ivvairių mechaninių ar elektroninių priemonių energijos sąnaudų minimizavimas gali būti atliktas pasinaudojant kelio planavimo metodais. Kai turimas konkretus roboto modelis be papildomų priemonių ir jam reikia išvažinèti tam tikrą paviršiaus plotą, tinkamas judèjimo planavimas gali pagerinti ne tik energetinį efektyvumą, bet ir judejjimo paklaidas (I. A. Hameed 2014, H. Kim et. al. 2014). Kelio planavimas leidžia ne tik tinkamai planuoti judejjimo trajektoriją lygiu keliu, bet ir nelygiu paviršiumi, kur yra kalnuotos ir duobetos vietos. Pagrindinis privalumas yra tai, kad kelio planavimas gali būti suderintas su kitais energijos sąnaudų minimizavimo metodais (kaip papildoma priemonè) ir tarpusavyje metodai nepakenks vienas kitam. Tačiau kelio planavimas yra sudetingas matematinis procesas, kuris reikalauja didelio valdymo sistemos pajègumo, o tai gali padidinti energijos sąnaudas.

Kelio planavimo metodus galima derinti, pavyzdžiui, su genetiniais algoritmais. Toks tyrimas buvo atliktas I. Chaari, A. Koubaa, S. Trigui, 
H. Bennaceur, A. Ammar ir K. Al-Shalfan mokslininkų naudojant mažą važiuojantị robotą (I. Chaari et. al. 2014). Derinant genetinị algoritmą kartu su skruzdžių kolonijos optimizavimo metodu (angl. ant colony optimization (ACO)) mokslininkų grupé pastebejjo, kad galima paimti privalumus tiek iš vieno metodo, tiek iš kito. Metodų derinimas davè puikius rezultatus minimizuojant energijos sąnaudas, užduoties atlikimo laiką ir kelio radimo tikimybę.

Kai kurie robotu veiksmai ir darbai gali reikalauti itin didelio energijos kiekio, pavyzdžiui judejjimas nelygiu paviršiumi ar šokinèjimas, kad ịveiktų neperlipamas kliūtis. Tokiais atvejais energijos suvartojimas turi būti ịdėmiai stebimas, kitaip per dideli energijos impulsai gali pakenkti robotui, pavyzdžiui, gali būti sugadinti roboto elektronikos komponentai ar valdymo sistema. Šaltinyje (H. Chai et. al. 2016) aprašyta, kaip tinkamai planuoti šokinejjimo parametrus, kad būtų sunaudojamas minimalus energijos kiekis. Buvo pastebėta, kad energijos kiekis ị sistemą turi būti paduodamas pagal norimą šokimo aukštị. Gaunama, kad robotas gali pašokti ị reikiamą aukštị nesuvartodamas didesnio energijos kiekio nei iš tikrujų reikia.

\subsection{Pirmojo skyriaus išvados ir disertacijos uždavinių formulavimas}

Atlikus literatūros analizę disertacijos tema buvo patvirtinta, kad darbo ịvade iškelti uždaviniai lieka neišspręsti ir aktualūs. Taip pat buvo padarytos šios išvados:

1. Viena iš svarbiausių vaikščiojančių robotų problemų yra didelès energijos sąnaudos, kurios dažniausiai atsiranda dèl didelio pavarų skaičiaus ar netinkamos roboto konstrukcijos (pvz. per didelè roboto masė). Šios problemos sprendimas yra aktualus ir leistų plačiau taikyti vaikščiojančius robotus atliekant realias užduotis.

2. Pagrindinis vaikščiojančių robotų privalumas lyginant su važiuojančiais ar vikšriniais robotais yra galimybė judèti nelygiais, žmogui sunkiai prieinamais, paviršiais, siekiant atlikti sudètingas ir pavojingas užduotis, tokias kaip išminavimas, gelbẻjimo operacijos, planetų paviršiaus tyrimai, povandeninès užduotys.

3. Išsamūs energijos sąnaudų tyrimai robotui įveikiant įvairias kliūtis yra svarbus uždavinys, nes pagrindinis vaikščiojančių robotų privalumas yra galimybė judeti nelygiais paviršiais. Taigi roboto 
gebejjimas judèti per kliūtis stipriai pagerintų vaikščiojančių robotų efektyvumą.

4. Iki šiol nėra nustatyta, kaip vaikščiojančių robotų energijos sąnaudos siejasi su paviršiaus nelygumais, todèl yra sunku rasti tinkamiausią metodą energijos sąnaudų minimizavimui robotui judant nelygiu paviršiumi. Prieš sprendžiant energijos sąnaudų optimizavimo uždavinį, būtina sukurti metodiką, leidžiančią nustatyti, kaip kinta roboto energijos sąnaudos keičiantis paviršiaus tipui ar kliūčių dydžiui.

5. Skirtingi energijos sąnaudų minimizavimo metodai gali būti taikomi tik konkretiems mobiliems robotams. Tačiau nagrinètuose šaltiniuose nèra aprašytų metodų, teikiančių informaciją apie bendrą roboto efektyvumą, o sukurti metodai nèra taikytini visoms robotų rūšims. Atliekant išsamius energijos sąnaudų tyrimus robotui judant paviršiais su skirtingo dydžio ir tankio kliūtimis būtų galima sukurti bendrą energijos sąnaudų minimizavimo metodą, tinkantị robotams su bet kokiu kojų skaičiumi.

Darbo tikslui pasiekti darbe reikia spręsti šiuos uždavinius:

1. Sudaryti šešiakojo roboto imitacinị ir fizinị modelius bei pèdų trajektorijų generavimo matematines išraiškas kliūčių perlipimui.

2. Ištirti roboto energijos sąnaudas ir jas lemiančius veiksnius judant lygiu paviršiumi ir ịvertinti judejjimo nuokrypius nuo numatytos judejjimo trajektorijos žingsniuojant paviršiais su ịvairaus dydžio ir tankio kliūtimis.

3. Sudaryti ir ištirti pėdų trajektorijų generavimo metodą, leidžiantị parinkti žingsnio parametrus siekiant minimizuoti energijos sąnaudas.

4. Ištirti roboto energijos sąnaudų priklausomybę nuo kliūčių dydžio ir tankio aplinkoje, taikant sudarytą pèdų trajektorijų generavimo metodą. 


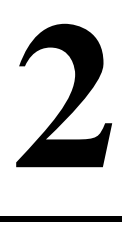

\section{Energetiškai efektyvaus judèjimo metodų sudarymas}

Šiame skyriuje sudaromi darbe naudojamo šešiakojo roboto matematinis ir fizinis modeliai, aprašomos eisenos ir pedų trajektorijų generavimo metodas, skirtas judejjimui lygiu paviršiumi. Taip pat pateikiamas fizinio roboto struktūros ir valdymo sistemos aprašymai. Skyriuje taip pat pateikiamas matematinio roboto modelio sudarymas $M A T L A B^{\circledR}$ programos aplinkoje, kuris leidžia patikrinti roboto ir jo funkcijų veikimą.

Skyriuje pateikiamas nelygaus paviršiaus klasifikavimo modelio sudarymas. Pateikiami nelygaus paviršiaus ir kliūčiu apibrèžimai. Kliūtys klasifikuojamos pagal dydį bei atsižvelgiant ị šešiakojo vaikščiojančio roboto dydį.

Taip pat pateikiami kliūčių aptikimo ir perlipimo metodų sudarymas. Aprašomi taktiliniai kojų jutikliai būtini kliūčių aptikimui aplinkoje. Pẻdų trajektorijų generavimo metodas patobulinamas integruojant galimybę keisti ne tik žingsnio aukštị ir ilgị, bet ir žingsnio plotị.

Skyriaus tematika paskelbti keturi autoriaus moksliniai straipsniai (T. Luneckas, M. Luneckas, D. Udris 2013; M. Luneckas, T. Luneckas, D. Udris 2013; D. D. Esteban, M. Luneckas, T. Luneckas, J. Kriaučiūnas, D. Udris 2016; A. Skaburskytė, M. Luneckas, T. Luneckas, J. Kriaučiūnas, D. Udris 2016). 


\section{1. Šešiakojo roboto matematinio ir fizinio modelių sudarymas}

Tyrimų objektas - šešiakojis vaikščiojantis robotas, kuris ant kiekvienos kojos turi po 3 LL. Tai yra standartinio tipo robotas, todèl matematiniam modeliui sudaryti naudojamas trigonometrinis metodas, kuriuo naudojantis yra paprasta išvesti atvirkštinès kinematikos lygtis, naudojamas roboto judejjimui valdyti.

Roboto kojos struktūra pavaizduota 2.1 paveiksle. Pirmasis sąnarys, kuris vadinamas klubo (lot. coxa) dalimi yra skirtas kojos judejimui $(x, y)$ plokštumoje valdyti. Antrasis ir trečiasis sąnariai (šlaunies (lot. femur) ir blauzdos (lot. tibia) dalys) yra skirti kojos judejjimui $z$ ašimi valdyti. Kojos pẻdos padètis erdvejje 2.1 paveiksle pavaizduota kaip taškas $\mathrm{P}(x, y, z)$. Šs taškas priklauso nuo visų trijų koordinačių. Geriausias būdas spręsti ši uždavinị yra išskaidyti trijų matmenų trigonometriją ị dviejų matmenų projekcijas, kaip pateikta 2.2 paveiksle.

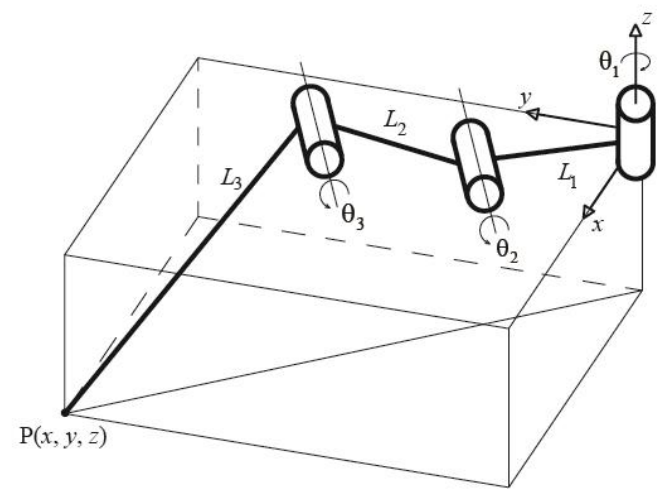

2.1 pav. Darbe naudojamo šešiakojo roboto kojos kinematinis modelis

Fig. 2.1. Kinematic model of hexapod robot leg used in the thesis

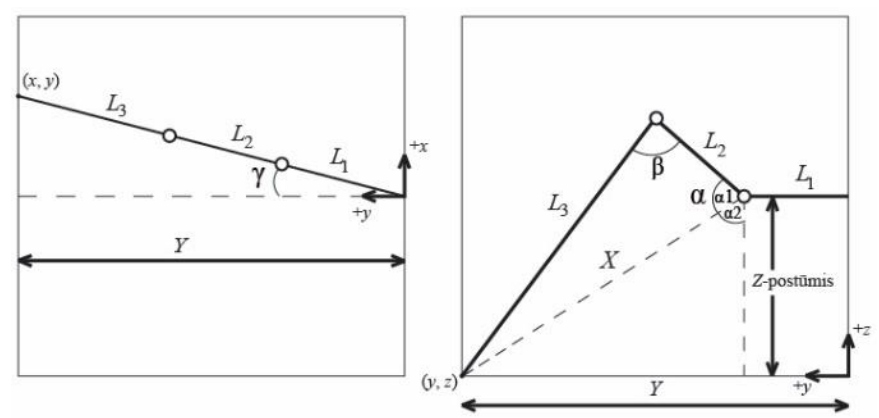

2.2 pav. 3 LL roboto kojos kinematinio modelio projekcijos i $x y$ ir $y z$ plokštumas

Fig. 2.2. Projection of $3-D O F$ robotic leg kinematic model to $x y$ and $y z$ planes 
Kad roboto koja būtų pilnai valdoma atvirkštinès kinematikos būdu, reikia rasti kampus $\alpha, \beta$ ir $\gamma$ (2.2 pav.). Iš kairiosios 2.2 paveikslo pusès nesunku nustatyti, kad kampas $\gamma$ išreiškiamas taip:

$$
\frac{x}{y}=\tan (\gamma) \rightarrow \gamma=\tan ^{-1}\left(\frac{x}{y}\right),
$$

čia $x$ - kojos ilgio projekcija ị $x$ koordinačių aši, $y$ - kojos ilgio projekcija ị $y$ koordinačių aši.

Belieka rasti kampus $\alpha$ ir $\beta$. Tam reikès nagrinèti 2.2 paveikslo dešiniają dalį. Matoma, kad abu kampai yra toje pačioje plokštumoje, tačiau kampą $\alpha$ rasti yra pakankamai keblu. Kampą $\alpha$ reikia išskaidyti ị kampus $\alpha_{1}$ ir $\alpha_{2}$. Dabar galima rasti kampą $\alpha_{1}$ randant ilgị $Y$ :

$$
\begin{gathered}
Y=\sqrt{Z_{\text {nuokrypa }}^{2}+\left(X-L_{1}\right)^{2}}, \\
\alpha_{1}=\cos ^{-1}\left(\frac{Z_{\text {nuokrypa }}}{X}\right) .
\end{gathered}
$$

Norint surasti $\alpha_{2}$, reikia pasinaudoti kosinusų teorema:

$$
\begin{aligned}
& \cos A=\frac{b^{2}+c^{2}-a^{2}}{2 \cdot b \cdot c}, \\
& \cos B=\frac{a^{2}+c^{2}-b^{2}}{2 \cdot a \cdot c}, \\
& \cos C=\frac{a^{2}+b^{2}-c^{2}}{2 \cdot a \cdot b} .
\end{aligned}
$$

čia $a, b$ ir $c$ - bet kokio trikampio kraštinių ilgiai, $A, B$ ir $C$ - šio trikampio kampai.

Žinant visas trikampio kraštines iš 2.2 paveikslo galima rasti $\alpha_{2}$ kampą:

$$
\begin{gathered}
L_{3}^{2}=L_{2}^{2}+X^{2}-2 \cdot\left(L_{2}\right) \cdot X \cdot \cos \left(\alpha_{2}\right), \\
\alpha_{2}=\cos ^{-1}\left(\frac{L_{3}^{2}-L_{2}^{2}-X^{2}}{-2 \cdot\left(L_{2}\right) \cdot X}\right) .
\end{gathered}
$$

Žinoma, kad $\alpha=\alpha_{1}+\alpha_{2}$. Dabar galima rasti galutinę kampo $\alpha$ išraišką iš formulių (2.3) ir (2.8):

$$
\alpha=\cos ^{-1}\left(\frac{Z_{\text {nuokrypa }}}{X}\right)+\cos ^{-1}\left(\frac{L_{3}^{2}-L_{2}^{2}-X^{2}}{-2 \cdot\left(L_{2}\right) \cdot X}\right) .
$$

Kampą $\beta$ galima išreikšti iš šios lygties: 


$$
\begin{gathered}
X^{2}=L_{3}^{2}+L_{2}^{2}-2 \cdot\left(L_{3}\right) \cdot\left(L_{2}\right) \cdot \cos (\beta), \\
\beta=\cos ^{-1}\left(\frac{X^{2}-L_{3}^{2}-L_{2}^{2}}{-2 \cdot\left(L_{3}\right) \cdot\left(L_{2}\right)}\right) .
\end{gathered}
$$

Pakeitus LL kampų žymejjimą galima gauti bendras atvirkštinès kinematikos išraiškas. Klubo, šlaunies ir blauzdos dalių ilgiai jau yra žinomi ir žymimi $L_{1}, L_{2}$ ir $L_{3}$. Klubo dalies kampas yra $\gamma$, šlaunies dalies kampas $-\alpha$, o blauzdos dalies kampas $-\beta$. Pervadinus šiuos kampus kaip klubo, šlaunies ir blauzdos kampus $\theta_{1}, \theta_{2}$ ir $\theta_{3}$ atitinkamai, lygtis (2.1), (2.9) ir (2.11) galima perrašyti bendraja forma:

$$
\begin{gathered}
\theta_{1}=\tan ^{-1}\left(\frac{x}{y}\right), \\
\theta_{2}=f_{1}+f_{2}, \\
\theta_{3}=\cos ^{-1}\left(\frac{L_{3}^{2}+L_{2}^{2}-B^{2}}{-2 \cdot L_{3} \cdot L_{2}}\right),
\end{gathered}
$$

čia:

$$
\begin{gathered}
B=\sqrt{l_{4}+z^{2}}, \\
l_{4}=\sqrt{x^{2}+y^{2}}-L_{1}, \\
f_{1}=\cos ^{-1}\left(\frac{L_{1}^{2}-L_{2}^{2}+B^{2}}{2 \cdot L_{3} \cdot B}\right), \\
f_{2}=\sin ^{-1}\left(\frac{z}{B}\right) .
\end{gathered}
$$

Matematiniam šešiakojo roboto modeliui sudaryti lygčių (2.12)-(2.18) nepakanka, nes nėra žinomi visų kojų postūmiai ir posūkiai kūno masès centro atžvilgiu, o taip pat reikia žinoti roboto kūno formą bei kūno ir kojų matmenis.

Visų pirma buvo sudaryta transformacijų matrica. Transformacijų matricoms sudaryti buvo naudojamas Denavito-Hartenbergo (D-H) kinematikos metodas. Tam buvo sudaroma D-H parametrų lentelè (2.1 lentelè).

2.1 lentelė. Denavito-Hartenbergo parametrų lentelè 3 LL roboto kojai Table 2.1. Denavit-Hartenberg parameters for 3-DOF robotic leg

\begin{tabular}{|c|c|c|c|c|c|c|}
\hline$j$ & $\theta$ & $d_{j}$ & $a_{j}$ & $\alpha_{j}$ & $\Sigma$ & $P$ \\
\hline 1 & $\theta_{1}$ & 0 & $L_{1}$ & $\pi / 2$ & 0 & 0 \\
\hline 2 & $\theta_{2}$ & 0 & $L_{2}$ & 0 & 0 & $-\pi / 6$ \\
\hline 3 & $\theta_{3}$ & 0 & $L_{3}$ & 0 & 0 & $2 \pi / 3$ \\
\hline
\end{tabular}


2.1 lentelèje $j$ - žymi LL (pavaras), $\theta_{j}-$ LL kampus, $d_{j}-$ LL prailginimus, $a_{j}$ - sąnarių ilgius, $\alpha_{j}-$ LL posūkius, $\Sigma-$ LL tipą, $P-$ LL postūmius.

Turint D-H parametrus galima sudaryti transformacijos matricas kiekvienam sąnariui:

$$
\begin{aligned}
A_{1} & =\left(\begin{array}{cccc}
\cos q_{1} & 0 & \sin q_{1} & L_{1} \cdot \cos q_{1} \\
\sin q_{1} & 0 & -\cos q_{1} & L_{1} \cdot \sin q_{1} \\
0 & 1 & 0 & 0 \\
0 & 0 & 0 & 1
\end{array}\right), \\
A_{2} & =\left(\begin{array}{cccc}
\cos q_{2} & -\sin q_{2} & 0 & L_{2} \cdot \cos q_{2} \\
\sin q_{2} & \cos q_{2} & 0 & L_{2} \cdot \sin q_{2} \\
0 & 0 & 1 & 0 \\
0 & 0 & 0 & 1
\end{array}\right), \\
A_{3} & =\left(\begin{array}{cccc}
\cos q_{3} & -\sin q_{3} & 0 & L_{3} \cdot \cos q_{3} \\
\sin q_{3} & \cos q_{3} & 0 & L_{3} \cdot \sin q_{3} \\
0 & 0 & 1 & 0 \\
0 & 0 & 0 & 1
\end{array}\right) .
\end{aligned}
$$

čia $A_{1}, A_{2}$ ir $A_{3}-1,2$ ir 3 LL (klubo, šlaunies ir blauzdos) transformacijos matricos atitinkamai.

Žinoma, kad bendra transformacijos matrica $T_{3}^{0}$ išreiškiama naudojant D-H transformacijos matricas:

$$
T_{3}^{0}=A_{1} \cdot A_{2} \cdot A_{3} .
$$

Instačius lygtis (2.19)-(2.21) ị lygtị (2.22), gaunama galutinè transformacijos matrica:

$$
T_{3}^{0}=\left[\begin{array}{cccc}
c_{123}-c_{1} s_{23} & -c_{12} s_{3}-c_{13} s_{2} & s_{1} & L_{1} c_{1}+L_{2} c_{12}+L_{3} c_{123}-L_{3} c_{1} s_{23} \\
c_{23} s_{1}-s_{123} & -c_{2} s_{13}-c_{3} s_{12} & -c_{1} & L_{1} s_{1}+L_{2} c_{2} s_{1}+L_{3} c_{23} s_{1}-L_{3} s_{123} \\
c_{2} s_{3}+c_{3} s_{2} & c_{23}-s_{23} & 0 & L_{2} s_{2}+L_{3} c_{2} s_{3}+L_{3} c_{3} s_{2} \\
0 & 0 & 0 & 1
\end{array}\right],
$$

čia $s_{1}-\sin \left(\theta_{1}\right), s_{2}-\sin \left(\theta_{2}\right), s_{3}-\sin \left(\theta_{3}\right), s_{12}-\sin \left(\theta_{1}+\theta_{2}\right), s_{13}-\sin \left(\theta_{1}+\theta_{3}\right)$, $s_{23}-\sin \left(\theta_{2}+\theta_{3}\right), s_{123}-\sin \left(\theta_{1}+\theta_{2}+\theta_{3}\right), c_{1}-\cos \left(\theta_{1}\right), c_{2}-\cos \left(\theta_{2}\right), c_{3}-$ $\cos \left(\theta_{3}\right), c_{12}-\cos \left(\theta_{1}+\theta_{2}\right), c_{23}-\cos \left(\theta_{2}+\theta_{3}\right), c_{123}-\cos \left(\theta_{1}+\theta_{2}+\theta_{3}\right)$.

Šešiakojo roboto kūnas pasirinktas šešiakampis su statiškai stabiliais parametrais (D. D. Esteban et. al. 2016): $20^{\circ}$ kampinių kojų posūkiai ir 0,45 m postūmiai vidurinèms kojoms. Šešiakojo roboto kinematinis modelis 
MATLAB ${ }^{\circledR}$ programos aplinkoje pavaizduotas 2.3 paveiksle. Kūno plotis $0,1 \mathrm{~m}$ priekinèje ir galinejje dalyse, $0,19 \mathrm{~m}$ - viduryje. Roboto kūno ilgis yra $0,25 \mathrm{~m}$. Kojų dimensijos yra šios: $L_{1}, L_{2}$ ir $L_{3}$ yra $0,052 \mathrm{~m}, 0,082 \mathrm{~m}$ ir $0,1 \mathrm{~m}$ atitinkamai. Platesnis šešiakojo roboto imitacinio modelio sudarymo aprašymas pateiktas šaltiniuose (T. Luneckas et. al. 2011, T. Luneckas et. al. 2012).

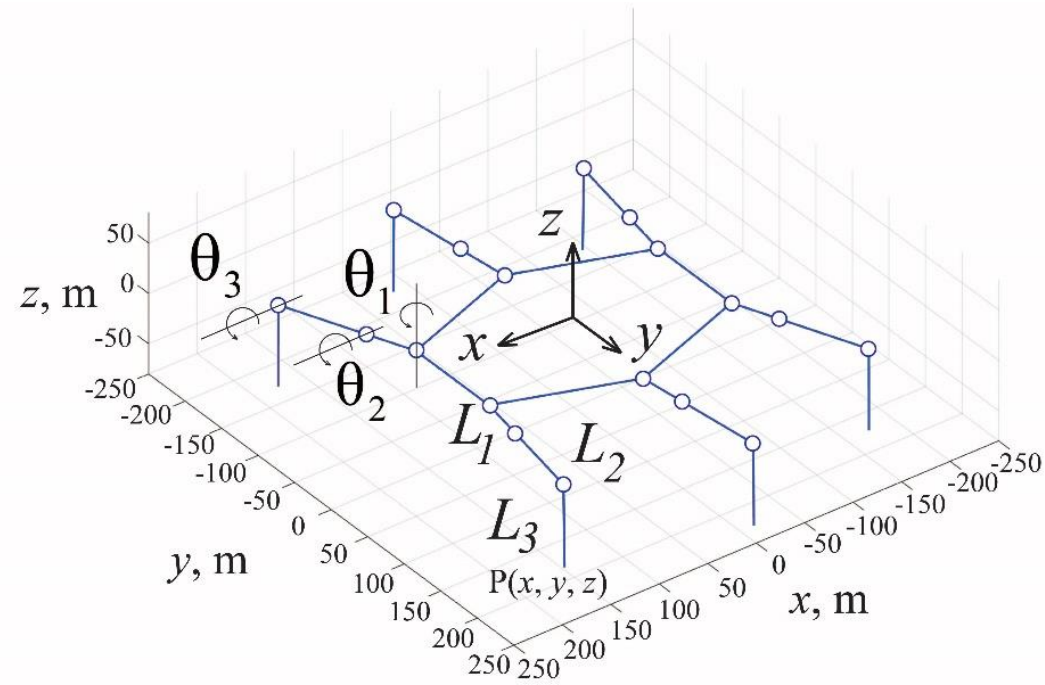

2.3 pav. Šešiakojo roboto kinematinis modelis $M_{A T L A B}{ }^{\circledR}$ programos aplinkoje

Fig. 2.3. Hexapod robot kinematic model inside MATLAB ${ }^{\circledR}$ program

Roboto judejjimui reikalingas pėdų trajektorijų generavimas. Pėdų trajektorijų generavimui sudaryti buvo koreguojamos ankstesniame darbe sudarytos pèdų trajektorijos (T. Luneckas 2013). Trajektorijos projekcijos zy ir $x y$ plokštumose pavaizduotos 2.4 paveiksle. Kaip matyti iš 2.4 paveikslo, zy plokštumoje pėdos judejjimas yra sinusoidès bangos formos. Tokia forma leidžia keisti roboto žingsnio ilgị, aukštị bei judejjimo kryptị. Tačiau norint tinkamai sudaryti pėdų trajektorijas, reikia išskaidyti projekcijas ị atskiras koordinačių priklausomybes nuo laiko. Siekiant patobulinti ankstesnes pédų trajektorijas buvo atlikti keli esminiai pakeitimai. Ankstesnių pėdų trajektorijų $x$ koordinatė atitikdavo roboto judejimą i šonus, o $y$ koordinate - pirmyn ir atgal. Toks pasirinkimas buvo netinkamas, nes dažnai koordinatès būdavo sumaišomos, todèl ịvykdavo roboto gedimas dẻl blogai suskaičiuotų atvirkštinès kinematikos verčių. Šiame darbe sudarant atskirų koordinačių priklausomybes nuo laiko, $x$ ir $y$ koordinatés buvo sutapatintos su standartiniu koordinačių sistemos žymėjimu, siekiant suvienodinti realaus roboto vaikščiojimą su matematinio modeliavimo aplinkoje esamo roboto vaikščiojimu. Šis pakeitimas taip pat leidžia laisviau 
valdyti roboto kojų judejjimus pirmyn-atgal ir į šonus. Kitas pakeitimas: buvo sukeistos $x$ ir $y$ koordinačiu lygtys. Roboto valdymas yra paprastesnis, kai $x$ koordinatė atitinka kojų judejjimą i priekị ir atgal, o taip pat toks žymèjimas yra vizualiai patogesnis. Atskirų koordinačių priklausomybès nuo laiko pavaizduotos 2.5 paveiksle.

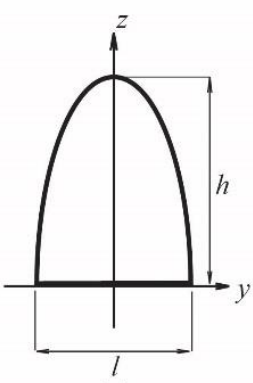

(a)

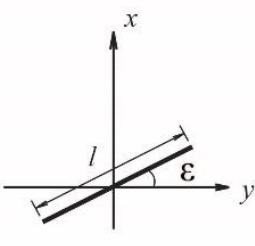

(b)

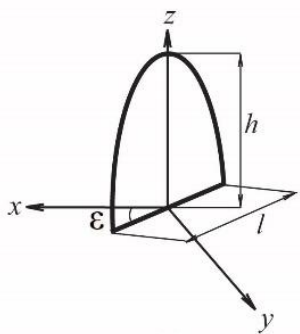

(c)

2.4 pav. Roboto pėdos trajektorijos projekcijos ị zy plokštumą (a), i xy plokštumą (b) ir erdvinis vaizdas (c); $l$ - žingsnio ilgis, $h$ - žingsnio aukštis, $\varepsilon$ - judejjimo kryptis. Čia žingsnio plotis $w=0 \mathrm{~m}$

Fig. 2.4. Robot's foot trajectory projections into $z y$ plane (a), $x y$ plane (b), and spatial view (c); $l$ - step length, $h$-step height, $\varepsilon$ - stride direction. Here step width $w=0 \mathrm{~m}$

2.5 paveikslas vaizduoja pėdos trajektorijos atskirų koordinačių priklausomybes nuo laiko. Akivaizdu, $\operatorname{kad} x(t)$ ir $y(t)$ priklausomybès yra tokios pačios. Remiantis 2.5 paveikslu, galima išskirti tris atvejus: kai laiko momentas yra lygus arba mažesnis nei kojos perkèlimo fazé, kai laiko momentas yra didesnis nei kojos perkèlimo fazé, bet lygus arba mažesnis nei perkèlimo fazè pridejjus laiko vienetą ir kai laiko momentas yra didesnis nei kojos perkélimo fazè pridèjus laiko vienetą.

- $t \leq \varphi_{i}$;

- $\varphi_{i}<t \leq \varphi_{i}+1$;

- $t>\varphi_{i}+1$.

Pirmuoju ir trečiuoju atveju, roboto koja yra palaikymo fazeje (pastatyta ant paviršiaus) ir stumiasi atgal. Todèl $x(t)$ ir $y(t)$ priklausomybès yra tiesès, einančios per taškus $0, \varphi_{i}$ ir $\varphi_{i}+1$ laiko atžvilgiu ir taškus $-l / 2,0$ ir $l / 2 x$ koordinatès atžvilgiu. Antruoju atveju roboto koja yra perkèlimo fazèje (daromas žingsnis). Todèl $z(t)$ priklausomybė yra tiesė tarp taškų 0 ir $\varphi_{i}, \varphi_{i}+1$ ir $T$ ir sinusoidès pusperiodis tarp taškų $\varphi_{i}$ ir $\varphi_{i}+1$. 

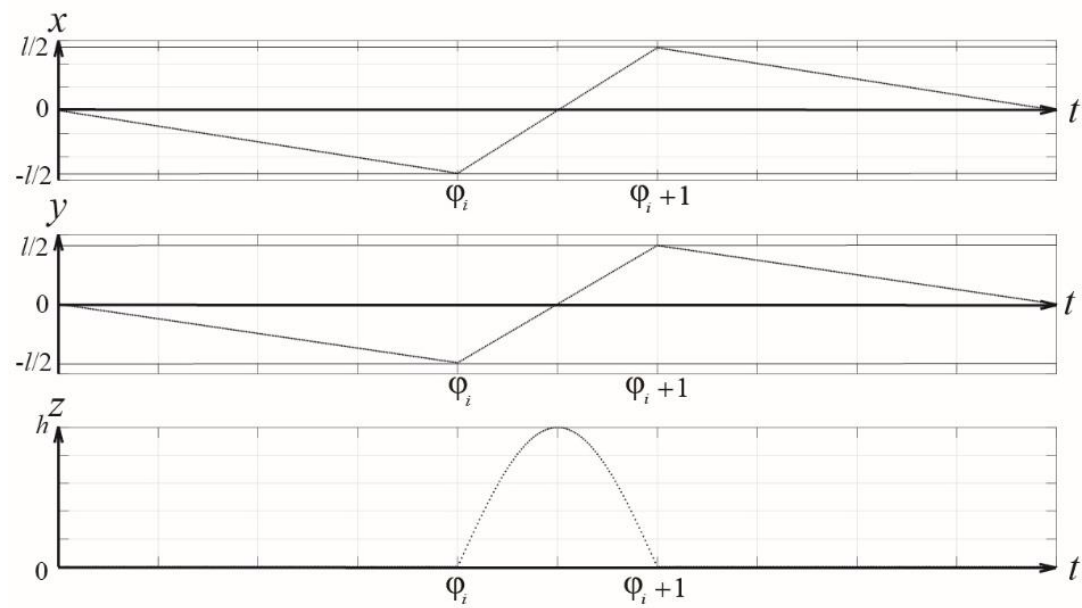

2.5 pav. Roboto pėdos trajektorijos atskirų koordinačių priklausomybès nuo laiko; $\varphi_{i}-$ $i$-tosios kojos perkèlimo fazè

Fig. 2.5. Robot's foot trajectory separate coordinate dependences on time; $\varphi_{i}-i$-th leg's transfer phase

Pagal šiuos tris atvejus ir pagal koordinačių priklausomybes nuo laiko galima sudaryti kiekvienos koordinatès lygtis:

$$
\begin{gathered}
x(t)= \begin{cases}-\cos (\varepsilon) \cdot\left(\frac{l \cdot\left(T-2 \cdot \varphi_{i}+2 \cdot t-1\right)}{2 \cdot(T-1)}+\frac{l}{2}\right), & \text { kai } t \leq \varphi_{i}, \\
\cos (\varepsilon) \cdot l \cdot\left(T-\varphi_{i}\right), & \text { kai } \varphi_{i}<t \leq \varphi_{i}+1, \\
\cos (\varepsilon) \cdot\left(\frac{l \cdot\left(T+2 \cdot \varphi_{i}-2 \cdot t+1\right)}{2 \cdot(T-1)}+\frac{l}{2}\right), & \text { kai } t>\varphi_{i}+1,\end{cases} \\
y(t)= \begin{cases}-\sin (\varepsilon) \cdot\left(\frac{l \cdot\left(T-2 \cdot \varphi_{i}+2 \cdot t-1\right)}{2 \cdot(T-1)}+\frac{l}{2}\right), & \text { kai } t \leq \varphi_{i}, \\
\sin (\varepsilon) \cdot\left(l \cdot\left(t-\varphi_{i}\right)\right), & \text { kai } \varphi_{i}<t \leq \varphi_{i}+1, \\
\sin (\varepsilon) \cdot\left(\frac{l \cdot\left(T+2 \cdot \varphi_{i}-2 \cdot t+1\right)}{2 \cdot(T-1)}+\frac{l}{2}\right), & \text { kai } t>\varphi_{i}+1,\end{cases} \\
z(t)= \begin{cases}0, & \text { kai } t \leq \varphi_{i}, \\
h \cdot \sin \left(\left(t-\varphi_{i}\right) \cdot \pi\right), & \text { kai } \varphi_{i}<t \leq \varphi_{i}+1, \\
0, & \text { kai } t>\varphi_{i}+1,\end{cases}
\end{gathered}
$$

čia $t$ - laikas, $T$-periodas. 
Pagal sudarytas roboto pėdos trajektorijas $x$ koordinatė atitinka roboto judejjimą tiesiai arba atgal (ilgis), $y$ koordinatė atitinka roboto judejjimą i kairę arba dešinę puses (plotis), o $z$ koordinatė atitinka aukštį.

Vienas iš svarbiausių aspektų kuriant robotus yra jų judejjimo planavimas (D. Henrich 1997). Netaikant judejjimo planavimo metodo, robotas tiesiog stovètų vietoje. Yra daug skirtingų robotų konfigūracijų (D. C. Kar 2003) ir dar daugiau skirtingų metodų skirtų roboto judejjimui valdyti. Tačiau vienas iš dažniausiai pasitaikančių robotų judejjimo metodų yra eisenos. Toliau aprašomos judèjimo eisenos, kurios buvo naudojamos darbe.

Kaip jau buvo apžvelgta 1 skyriuje, šešiakojų robotų pagrindinès eisenos yra trys: trikojè (angl. tripod), dvikojè (angl. tetrapod) ir banguojanti (angl. wave). Tačiau šiame darbe buvo naudojamos keturios eisenos: trys pagrindinès ir banguojančios eisenos modifikacija - pulsuojanti (angl. ripple) eisena.

Kiekvieną eiseną galima išskaidyti ị dvi fazes: palaikymo fazè ir perkèlimo fazè. Palaikymo fazès metu koja liečiasi su paviršiumi, išlaiko roboto svorị ir stumiasi atgal, kad sukurtu judejjimą. Perkèlimo fazès metu koja yra pakeliama ị viršų (daromas žingsnis) ir vẻliau leidžiama žemyn. Kiekviena eisena skiriasi šių dviejų fazių išdėstymu kiekvienai kojai (kojų perkèlimo eiliškumu). Taip pat skiriasi ir kiekvienos eisenos periodas, kuris priklauso nuo to, kiek kojų bus perkeliama vienu metu. Kiekvienos darbe naudojamos eisenos kojų perkèlimo fazès ir periodai pateikti 2.2 lentelèje. Kojų pavadinimų sutrumpinimai yra tokie:

$\mathrm{KP}$ - kaire priekiné;

$\mathrm{KV}$ - kairè viduriné;

$\mathrm{KG}$ - kairè galiné;

$\mathrm{DP}$ - dešinè priekiné;

DV - dešinè viduriné;

DG - dešinė galinè.

2.2 lentelè. Darbe naudojamų eisenų kojų perkèlimo fazès ir periodai

Table 2.2. Leg transfer phases and periods of different gaits used in the thesis

\begin{tabular}{|c|c|c|c|c|c|c|c|}
\hline Eisena & $T$ & $\varphi_{K P}$ & $\varphi_{K V}$ & $\varphi_{K G}$ & $\varphi_{D P}$ & $\varphi_{D V}$ & $\varphi_{D G}$ \\
\hline Trikojè & 2 & 0 & 1 & 0 & 1 & 0 & 1 \\
\hline Dvikojè & 3 & 0 & 1 & 2 & 1 & 2 & 0 \\
\hline Banguojanti & 6 & 0 & 1 & 2 & 3 & 4 & 5 \\
\hline Pulsuojanti & 6 & 0 & 2 & 4 & 5 & 3 & 1 \\
\hline
\end{tabular}

Perkèlimo fazè lygi 0 reiškia, kad ši koja bus perkeliama pirmoji, 1 - antroji ir t. t. Taigi trikojès eisenos metu visų pirma bus perkeliamos KP, DG ir DV, o vèliau KV, DP ir DG. Kaip matome trikojès eisenos metu perkeliamos vienos 
pusès priekinè ir galinè ir kitos pusès vidurinè kojos. Dvikojès eisenos metu visų pirma perkeliamos KP ir DG kojos, tada $\mathrm{KV}$ ir DP ir galu gale KG ir DV. Banguojančios eisenos kojų perkèlimo eiliškumas yra toks: KP, KV, KG, DP, DV ir DG. Pulsuojančios eisenos kojų perkèlimo eiliškumas yra toks: KP, DG, KV, DV, KG ir DP. Sprendžiant pagal eisenų periodus, trumpiausiai trunkanti eisena yra trikojè, o ilgiausiai trunkančios eisenos yra banguojanti ir pulsuojanti.

Suvedus šiuos parametrus ị gautas pėdų trajektorijas, išreikštas lygtimis (2.24)-(2.26), gaunamas nuoseklus šešiakojo roboto judejjimas skirtingomis eisenomis.

Visų darbe naudojamų eisenų grafinis atvaizdavimas pateiktas 2.6 paveiksle. Kaip matoma iš 2.2 lentelès ir 2.6 paveikslo, visos eisenos (išskyrus banguojančią ir pulsuojančią) skiriasi periodais. Trikojès eisenos periodas yra sudarytas iš 2 etapų, dvikojès - iš 3 etapų, banguojančios ir pulsuojančios eisenų periodai - iš 6 etapų. Trikojès eisenos metu perkeliamos trys kojos, o kitos lieka palaikymo fazèje. Dvikojès eisenos metu perkeliamos dvi kojos, o keturios lieka palaikymo fazejje. Banguojančios ir pulsuojančios eisenų metu perkeliama tik viena koja, o kitos penkios lieka palaikymo fazeje. Vienintelis skirtumas tarp banguojančios ir pulsuojančios eisenų yra tik kojų perkèlimo eiliškumas.

Pagal šiuos duomenis taip pat galima nustatyti ir eisenų greiti bei stabilumą. Mažiausiai stabili, bet greičiausia eisena yra trikojè, dèl didžiausio kojų perkèlimo skaičiaus ir mažiausio eisenos periodo. Vienas iš būdų roboto stabilumui garantuoti yra jègų pasiskirstymas tarp kojų (M. S. Erden et. al. 2007). Tačiau standartinis stabilumo kriterijus sako, kad mažiausiai trys kojos turi būti ant paviršiaus visą laiką, kad būtų išlaikomas statinis ir dinaminis stabilumai. Trikoje eisena ši kriterijų tenkina, tačiau minimaliai.

Šiek tiek lètesnè bet stabilesnè eisena yra dvikojè. Šios eisenos stabilumas yra geresnis dèl to, kad keturios kojos pastoviai yra ant paviršiaus. Pati stabiliausia ir lèčiausia eisena yra banguojanti, nes vienu metu perkeliama yra tik viena koja. Šios eisenos metu ant paviršiaus pastoviai yra penkios kojos, todèl stabilumo kriterijus tenkinamas maksimaliai. Banguojanti eisena yra netgi stabilesnè nei pulsuojanti eisena, nes kojų perkèlimo eiliškumas yra nuoseklus, o pulsuojančios eisenos kojų perkèlimo eiliškumas nèra nuoseklus. Eisenų stabilumo tyrimas plačiau aprašytas šaltinyje (A. Skaburskyte et. al. 2016).

Šešiakojo roboto HexaV4 fiziniam modeliui konstruoti buvo pasirinkti šie komponentai: AX-12 servo pavaros, STM32F411RE mikrovaldiklis (ARM Cortex M4 architektūros), sumontuotas STM32 Nucleo-F411RE bandymų plokšteje, servomechanizmų AX-12 duomenų sąsajos suderinimo schema, pagal gamintojo rekomendacijas sudaryta iš loginių grandynų 74HC126 ir 74HC04 (Robotis 2006), LM7805 tipo $5 \mathrm{~V}$ itampos stabilizatorius mikrovaldikliui, elektros srovès stiprio matavimo schema. Kiekviena roboto koja turi po 3 LL, o robotas turi 6 kojas, todèl visumoje robotas gaunasi 18 LL sistema. Duomenims 
iš roboto mikrovaldiklio siųsti $\mathfrak{i}$ asmeninị kompiuterị tolimesniam kaupimui ir apdorojimui naudojamas Bluetooth ryšio modulis, keičiantis asinchroninę nuosekliają duomenų sąsają bevieliu ryšiu. Mikrovaldiklio programa atlikus pakeitimus ịkeliama iš asmeninio kompiuterio per USB sąsają, naudojant STM32 Nucleo-F411RE bandymų plokšteje imontuotą ST-Link V2 programavimo bei derinimo schemą. Šešiakojo roboto valdymo sistemos funkcinè elektrinè schema pavaizduota 2.7 paveiksle.

(a)

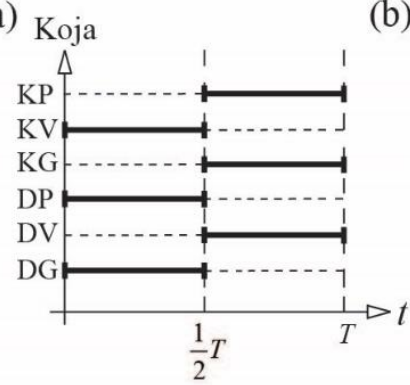

(c)

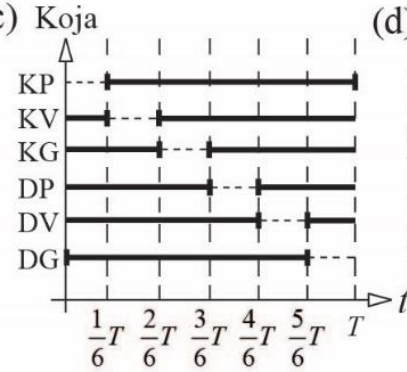

(b)

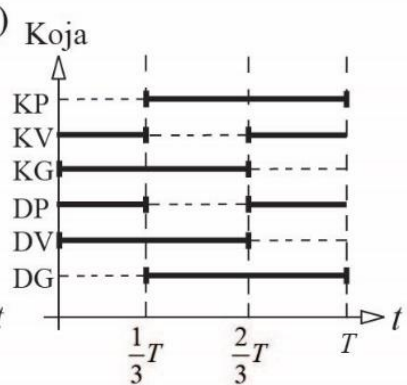

(d) Koja

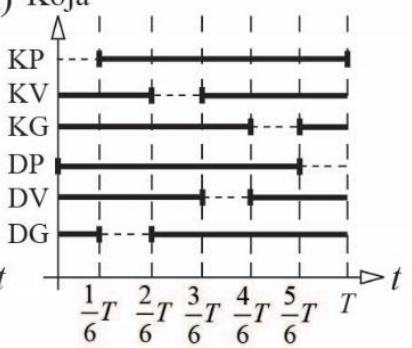

2.6 pav. Eisenų grafinis atvaizdavimas: (a) trikojè; (b) dvikojè; (c) banguojanti; (d) pulsuojanti

Fig. 2.6. Graphical representation of all gaits: (a) tripod; (b) tetrapod; (c) wave; (d) ripple

Eksperimentų metu šešiakojis robotas maitinamas naudojant reguliuojamą laboratorini nuolatinès įtampos šaltini, kurio įtampa nustatyta $11 \mathrm{~V}$, nes servo pavaroms AX-12 reikia 10-12 V itampos. Mikrovaldiklio modulis maitinamas 5 V ịtampa, todèl ịmontuotas LM7805 tipo ịtampos stabilizatorius kartu su dviem elektrolitiniais kondensatoriais, kuriu talpa $100 \mu \mathrm{F}$ ir dviem keraminiais kondensatoriais, kurių talpa $0,1 \mu \mathrm{F}$. Pagal gamintojo rekomendacijas duomenu sąsajos suderinimo schema sudaryta iš dviejų valdomų kartotuvų su trijų būsenų išejjimais, kuriems panaudotas $74 \mathrm{HC} 126$ tipo integrinis grandynas. Norint duomenų perdavimo krypti valdyti vienu mikrovaldiklio signalu, panaudotas inverteris (74HC04 tipo integrinis grandynas). Siekiant užtikrinti 
servomechanizmų valdymo signalo aukštą loginị lygi artimą $5 \mathrm{~V}$, kartotuvo išejimas per $10 \mathrm{k} \Omega$ varžos rezistorių $\mathrm{R} 1$ prijungtas prie $5 \mathrm{~V}$ įtampos šaltinio. Taip pat modernizuota STM32 Nucleo-F411RE bandymų plokšteje esanti mikrovaldiklio taktavimo schema - panaudotas išorinis $16 \mathrm{MHz}$ kvarcinis rezonatorius $\mathrm{X} 3$, prie kurio prijungti $20 \mathrm{pF}$ kondensatoriai. Tai leido lanksčiau programiškai keisti mikrovaldiklio veikimo spartą.

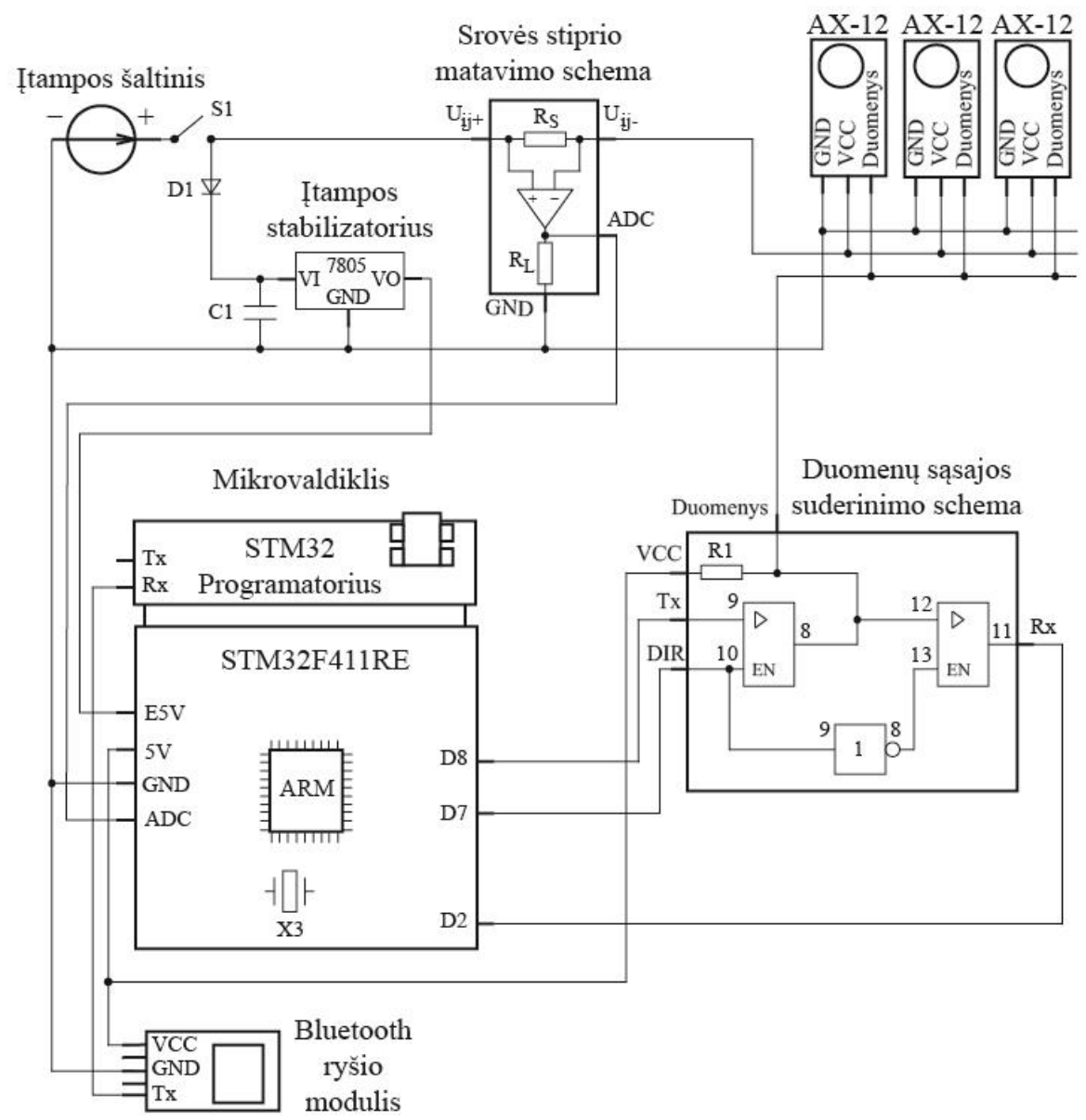

2.7 pav. Šešiakojo roboto valdymo sistemos funkcinè elektrinè schema

Fig. 2.7. Hexapod robot control system function electric diagram

Labai svarbi roboto valdymo sistemos dalis yra elektros srovès stiprio matavimo schema, kuri sudaryta iš šunto varžos $R_{S}$, specializuoto integrinio grandyno INA169 ir varžos $R_{L}$, kuri keičia išējimo elektros srovès stiprị ị itampą. Toks elektros srovès stiprio matavimo metodas pasirinktas todèl, kad tai 
yra klasikinis metodas ir lyginant su kitais metodais (pvz. Holo jutiklis), šunto varžos metodas pasižymi mažais triukšmais ir mažomis paklaidomis.

Gamintojo pateikiamoje INA169 grandyno dokumentacijoje (Texas Instruments 2005) buvo pateikta charakteristika, pagal kurią ir buvo skaičiuojamos reikiamos $R_{S}$ ir $R_{L}$ varžų vertès:

$$
U_{\text {ǐ̌ }}=I_{\mathrm{S}} \cdot R_{\mathrm{S}} \cdot 1000 \mu \frac{\mathrm{A}}{\mathrm{V}} R_{\mathrm{L}},
$$

čia $U_{i \check{s}}$ - išèjimo įtampa, $I_{S}$ - apkrovos elektros srovès stipris.

Visų pirma, pagal elektros srovès stiprio intervalą buvo parinkta $R_{S}$ varžos vertè. Gauta, kad tinkamiausia $R_{S}$ varžos vertė yra $0,1 \Omega$, pasirinktas $2 \mathrm{~W}$ leistinos sklaidomos galios ir $1 \%$ tikslumo 2010 korpuso SMD rezistorius. Toliau buvo parenkama $R_{L}$ varžos vertè. Šią vertę geriausia buvo parinkti tokią, kad išejimo ịtampos verte atitiktu elektros srovés stiprị patogiu santykiu $1 \mathrm{~A} / 1 \mathrm{~V}$. Pagal gamintojo aprašyme pateiktą formulę apskaičiavus pasirinktas $R_{L}$ rezistorius yra $10 \mathrm{k} \Omega$ varžos, $1 \%$ tikslumo ((2.28) lygtis).

$$
R_{\mathrm{L}}=\frac{3,3 \mathrm{~V}}{3,3 \mathrm{~A} \cdot 0,1 \Omega \cdot 1000 \cdot 10^{-6} \frac{\mathrm{A}}{\mathrm{V}}} .
$$

Taip pat buvo patikrinta galima INA169 grandyno matavimo paklaida pagal dokumentacijoje pateiktą charakteristiką. Esant $25{ }^{\circ} \mathrm{C}$ aplinkos temperatūrai (tipinè roboto veikimo sąlyga), kai ịejjimo įtampa yra lygi $15 \mathrm{mV}$, gaunama $2 \%$ elektros srovès stiprio matavimo paklaida $(\sim 150 \mathrm{~mA})$. Tačiau iš charakteristikos taip pat matyti, kad didèjant įejimo ịtampai, elektros srovès stiprio matavimo paklaida mažeja. Rezultatai rodo, kad elektros srovės stiprio matavimo schema yra sudaryta tinkamai ir darbe naudojama vaikščiojančio roboto energijos sąnaudoms ịvertinti.

Valdymo sistemai tenkantis elektros srovès stipris yra labai mažas $100 \mu \mathrm{A} / \mathrm{MHz}$. Gamintojo duomenimis, esant maksimaliam $100 \mathrm{MHz}$ vidiniam taktų dažniui, 3,6 V maitinimo ịtampai ir ijungtiems visiems vidiniams resursams, procesoriaus srovė neviršija $25 \mathrm{~mA}$. Bluetooth ryšio moduliui reikia $\sim 20 \mathrm{~mA}$ elektros srovès stiprio siuntimo režime. Palyginimui, vienos servo pavaros ramybès būsenoje elektros srovès stipris yra apie $84 \mathrm{~mA}$, veikimo metu - iki $900 \mathrm{~mA}$. Darbe naudojamas šešiakojis robotas turi $18 \mathrm{LL}$, todèl viso yra 18 servo pavaru. Taigi valdymo sistemai kartu su Bluetooth ryšio moduliu tenkantis elektros srovès stipris yra nykstamai mažas, panaudojus specializuotą mažo suvartojimo valdiklị ir Bluetooth 4.0 (BLE) sąsają gali būti dar sumažintas dešimtis kartų, todèl darbe nebuvo matuojamas bei ịskaitomas. Dèl šios priežasties elektros srovès stiprio matavimo schema jungiama tarp maitinimo šaltinio ir servo pavarų. Tokiu būdu buvo stebima, koks elektros srovès stipris 
tenka visoms pavaroms ir vèliau gautas elektros srovès stipris buvo perskaičiuojamas ị energijos sąnaudas.

Galutinis šešiakojo roboto HexaV4 ir jo valdymo sistemos pavyzdys yra pavaizduotas 2.8 paveiksle. Matyti, kad pagrindiniai roboto valdymo sistemos komponentai yra mikrovaldiklis, Bluetooth ryšio modulis, elektros srovès stiprio matavimo schema ir duomenų sąsajos suderinimo schema.
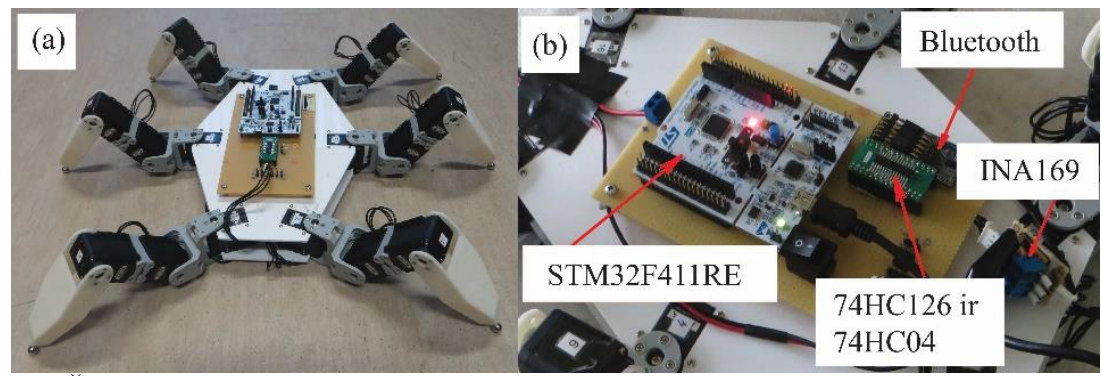

2.8 pav. Šešiakojis robotas HexaV4: (a) fizinis modelis; (b) valdymo sistemos sudètinès dalys

Fig. 2.8. Hexapod robot HexaV4: (a) physical model; (b) control system components

\subsection{Paviršiaus klasifikavimo modelio sudarymas}

Paviršiaus aptikimas, identifikavimas ir klasifikavimas yra svarbūs uždaviniai robotikoje, nes robotai privalo gebèti atpažinti savo aplinką, kad joje galėtų orientuotis ir nukeliauti iš vieno taško ị kitą. Jei robotas negebès atpažinti kliūčių ar paviršiaus tipo, jis paprasčiausiai atsitrenks ị kalnus, uolas ir todèl gali įvykti gedimas ir roboto veikla bus nutraukta.

Yra daug metodų, kaip atpažinti aplinką ir ją suvokti, tačiau vienas iš dažniausiai pasitaikančių metodų yra susijęs su stereo kamerų panaudojimu (S. Zenker et. al. 2013). Naudojant stereo kameras galima pasiekti net apie $90 \%$ tikslumą atpažịstant tokius paviršius kaip akmenys, žolè, asfaltas, smèlis ir panašiai. Tačiau tokio metodo trūkumas yra tai, kad gaunamas labai didelis informacijos kiekis. Informacijos apdorojimas užtrunka ilgą laiką, ypač jei norima gauti spalvotą vaizdą, kuris suteiktų daugiau informacijos apie aplinką.

Kitas pasitaikantis metodas paviršiaus atpažinimui yra susijęs su 2D lazerinių skenerių panaudojimu (D. Belter et. al. 2011). Tokių metodų principas dažniausiai yra gautu 2D žemèlapių pavertimas ị 3D žemèlapi, kuris vẻliau perduodamas ị roboto valdymo sistemą arba naudojamas kelio planavimui. Visų pirma yra skenuojama aplinka ir gaunamas 2D žemėlapis. Tada pritaikomas vienas iš vaizdų atpažinimo algoritmų, kuris leidžia dvimačius vaizdus paversti trimačiais. Privalumas yra tai, kad naudojantis tokiu metodu, robotas gali 
palyginus greitai apdoroti gautą iš aplinkos informaciją realiu laiku judant nežinomoje teritorijoje.

Svarbu pabrěžti, kad paviršiaus atpažinimas ir klasifikavimas yra du skirtingi metodai. Pirmasis metodas skirtas aptikti paviršiaus nelygumus ar kliūtis, taip pat įvertinti, kada koja yra pastatyta ant paviršiaus ir kokiame aukštyje yra. Antrasis metodas skirtas suskirstyti skirtingus paviršiaus tipus i klases pagal tam tikrus kriterijus. Paviršiaus skirstymas yra reikalingas tam, kad robotui būtų lengviau ịvertinti aplinką ir tinkamai pasirinkti judejjimo kelią bei parametrus (pvz. greitị, eiseną), kad judètų efektyviai ir suvartotų mažesnị energijos kieki.

Šiuo metu robotikos srityje daugiausiai darbų yra susijusių su vaikščiojančių robotų judejimu per nelygų paviršių, todèl populiariausias metodas paviršiaus nelygumų skirstymui yra pagal paviršiaus tipą. Iprastai išskiriami tokie paviršiai: žolè, asfaltas, lapai, pjuvenos, smèlis, gruntas, cementas, akmenys, žemè, plytelès (N. Kottege et. al. 2015, K. Walas 2015). Tai dažniausiai aplinkoje pasitaikantys paviršiaus tipai ir robotams tikrai teks judèti per panašaus tipo aplinkas.

Kitas būdas grupuoti paviršius yra grupavimas pagal kategoriją, taip pat iskaitant ir kiekvienos kategorijos galimus variantus. Tai yra šiek tiek sudètingesnis metodas, nes visi paviršiaus tipai suskirstomi i atskiras, smulkesnes kategorijas (G. Best et. al. 2013). Pavyzdžiui, akmenys suskirstomi i tokias kategorijas: smèlis, smulkūs akmenys, akmenys ir stambūs akmenys. Taip pat galima skirstyti pagal spalvą, pavyzdžiui, žolè: tamsi žolè, šviesi žolè, labai šviesi žolè, išblukusi žolè. Toks metodas yra itin geras, nes robotas gauna išsamesnę informaciją apie tokio paties paviršiaus skirtingas kategorijas ir gali tinkamai ịvertinti aplinką.

Pats primityviausias būdas skirstyti paviršių yra pagal judejjimo galimybę: galima ịveikti, negalima ịveikti. Toks metodas paprastai taikomas judejjimo trajektorijos planavimui (M. Kruusmaa 2003, V. R. Jisha et. al. 2012). Paviršiaus nelygumai skirstomi i dvi kategorijas: kliūtis ir lygus paviršius. Tačiau toks paviršiaus skirstymo metodas nesuteikia jokios informacijos apie paviršiaus tipą ar apie kliūčių aukštị, todèl taikomas tik labai konkrečiais atvejais ar matematinio modeliavimo aplinkose.

Šiame darbe buvo klasifikuojamos kliūtys, jų dydis bei paviršius, atsižvelgiant ị kliūčių dydị ir tankị aplinkoje. Buvo nustatyti esminiai skirtumai tarp nelygaus paviršiaus ir kliūčių. Kliūčių dydis tapatinamas su roboto galimybèmis ir sudaromos kliūčių dydžių matematinès išraiškos. Tyrimai buvo atliekami su imitaciniu roboto modeliu ir su realiu, todèl kliūtys skirstomos dviem būdais. Pirmuoju atveju kliūčių dydžiai tapatinami su šešiakojo roboto matematiniu modeliu, kai roboto kūnas yra plokščias (kūno storis yra lygus 0 ). Antruoju atveju kliūčių dydžiai tapatinami su fiziniu šešiakojo roboto modeliu, 
kurio kūno storis nèra lygus 0 , todèl judejjimo parametrai šiek tiek skiriasi nuo matematinio modelio. Taip pat, imitacinis roboto modelis buvo idealizuotas, siekiant ištirti, kiek energijos sunaudojama išoriniams veiksniams kompensuoti.

Visų pirma svarbu nustatyti, kas yra nelygus paviršius, o kas yra kliūtis. Nelygu paviršių galima apibrèžti kaip pastovus paviršiaus aukščio kitimą. Nelygaus paviršiaus aukštis gali kisti labai ịvairiai (silpai, stipriai), tačiau dažniausiai jis yra įveikiamas. Tuo tarpu kliūtis gali būti apibrèžta kaip atskiras paviršiaus aukščio pasikeitimas. Iš esmès nelygų paviršių galima apibūdinti kaip didelị kiekị kliūčių, esančių arti viena kitos (liečiasi tarpusavyje). Atskiros kliūtys yra individualūs objektai, kuriuos galima nusakyti ilgiu, pločiu ir aukščiu.

Darbe taip pat buvo atskiriamos dvi kliūčių kategorijos. Pirmajai kategorijai buvo priskiriamos svarbios kliūtys, kitai kategorijai - kliūtys, kurios neįtakos roboto judejjimo kelio (2.9 pav.). Pirmajai kategorijai priskirtos kliūtys yra tos, kurias robotui teks perlipti, o visos kitos kliūtys nèra svarbios, nes jų padètys yra ne roboto kelyje. Kiekvieną kliūti galima apibūdinti trimis parametrais: ilgis $L$, plotis $W$ ir aukštis $H$.

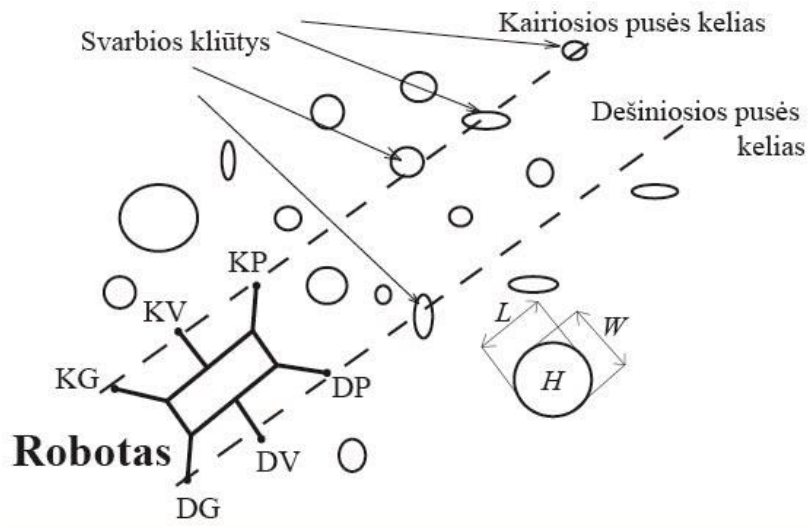

2.9 pav. Skirtingos kliūtys roboto kelyje

Fig. 2.9. Different obstacles along robots path

Roboto judejjimo parametrus nusako šie dydžiai: žingsnio ilgis $l$, plotis $w$ ir aukštis $h$. Siejant kliūčių dydžius su roboto judejjimo parametrais kliūtis galima skirstyti i keturias grupes:

- Lygus paviršius. Tai nebūtinai turi būti $0 \mathrm{~mm}$ aukščio paviršius, tačiau nelygumai tokie maži, kad robotui judant tokioje aplinkoje nereikia keisti judejjimo parametrų. Lygus paviršius matematiškai gali būti išreikštas taip:

$$
H<h_{\mathrm{i}},
$$


čia $h_{\mathrm{i}}$ - roboto žingsnio aukštis judant lygiu paviršiumi.

- Mažos kliūtys. Tai tokio dydžio kliūtys, kurių robotas negali ignoruoti, tačiau gali perlipti keičiant žingsnio parametrus. Mažas kliūtis matematiškai galima išreikšti taip:

$$
\begin{aligned}
& L \in\left[l_{\mathrm{i}}, l_{\max }\right], \\
& H \in\left[h_{\mathrm{i}}, h_{\max }\right], \\
& W \in\left[w_{\mathrm{i}}, w_{\max }\right],
\end{aligned}
$$

čia $l_{\mathrm{i}}$ ir $w_{\mathrm{i}}$ - roboto žingsnio ilgis ir plotis judant lygiu paviršiumi atitinkamai, $l_{\max }, w_{\max }$ ir $h_{\max }-$ maksimalus roboto žingsnio ilgis, plotis ir aukštis atitinkamai.

- Vidutinès kliūtys. Kitaip tokias kliūtis galima pavadinti „ilgomis“ kliūtimis. Tokių kliūčių ilgis ir plotis yra didesni nei maksimalūs roboto galimi žingsnio ilgis ir plotis, tačiau aukštis yra ịveikiamas. Tokias kliūtis robotas gali perlipti statant kojas ant kliūties viršaus. Matematiškai tokias kliūtis apibūdinti galima taip:

$$
\begin{aligned}
& L \in\left[l_{\max }, \infty\right], \\
& H \in\left[h_{\mathrm{i}}, h_{\max }\right], \\
& W \in\left[w_{\mathrm{i}}, \infty\right] .
\end{aligned}
$$

- Didelès kliūtys. Tai yra tokios kliūtys, kurios negali būti įveiktos jokiais judèjimo metodais. Tokių kliūčių pavyzdžiais gali būti uolos, statūs kalnai, vandens telkiniai. Vienintelis būdas išvengti tokias kliūtis yra kelio planavimas ir jų apejjimas. Dideles kliūtis matematiškai apibrèžti galima taip:

$$
\begin{aligned}
& L \in\left[l_{\max }, \infty\right], \\
& H \in\left[h_{\max }, \infty\right], \\
& W \in\left[w_{\max }, \infty\right] .
\end{aligned}
$$

Toliau buvo nustatomi darbe naudojamo šešiakojo roboto maksimalūs judèjimo parametrai. Visi tyrimai buvo atliekami robotui judant, kai kūnas yra neutralioje padėtyje. Tokia stovèsena gaunama tada, kai šlaunies ir blauzdos kojų dalys yra statmenos viena kitai (2.10 pav.). Roboto judejjimo parametrus nustatantys dydžiai neutralioje stovėsenoje pavaizduoti 2.10 paveiksle.

Norint apibrèžti roboto judèjimo ribas reikia nusakyti pradinius ir maksimalius pėdos trajektorijos parametrus: žingsnio ilgị, ploti ir aukštį. Pradiniai judejjimo parametrai paprastai yra tokie: $l_{\mathrm{i}}=0,05 \mathrm{~m}, w_{\mathrm{i}}=0 \mathrm{~m}$, $h_{\mathrm{i}}=0,01 \mathrm{~m}$. Toliau pateiktas roboto maksimalių pédos trajektorijos parametrų nustatymas. 


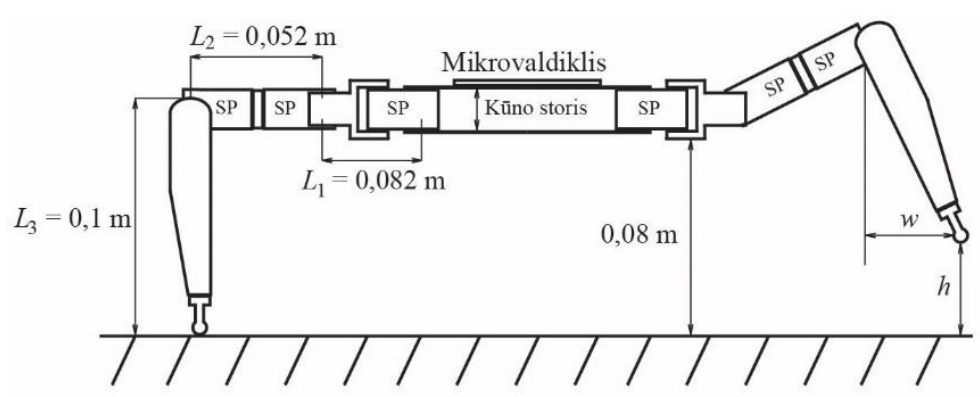

2.10 pav. Šešiakojo roboto geometrinis modelis, nusakantis kojos dydị ir žingsnio parametrus, neutralioje stovėsenoje

Fig. 2.10. Hexapod robot geometrical model, which describes leg size and step parameters, during neutral stance

Visų pirma buvo nagrinejjami imitacinio roboto modelio judejimo parametrai. Maksimalus žingsnio ilgis priklauso nuo blauzdos kojos dalies ilgio ir dalinai nuo šlaunies kojos dalies ilgio. Šio parametro neapriboja roboto kūnas, todèl maksimalus imitacinio roboto modelio žingsnio ilgis yra $0,1 \mathrm{~m}$. Žingsnio plotis labiausiai priklauso nuo šlaunies kojos dalies ilgio. Tačiau šis parametras yra mechaniškai ribojamas blauzdos kojos dalies, todèl maksimalus imitacinio roboto modelio žingsnio plotis yra $0,08 \mathrm{~m}$. Žingsnio aukštis labiausiai priklauso nuo blauzdos kojos dalies ilgio, tačiau dalinai yra ribojamas kūno storio. Imitacinio roboto modelio kūnas yra plokščias, todèl toks apribojimas negalioja. Žingsnio aukštis taip pat padidinamas dèl šlaunies kojos dalies, todèl maksimalus imitacinio roboto modelio žingsnio aukštis yra $0,12 \mathrm{~m}$.

Turint šiuos duomenis buvo patikslintos kliūčiu skirstymo lygtys (2.29)(2.32) šešiakojo imitacinio roboto modelio atveju:

- Lygus paviršius:

$$
H<0,01 \mathrm{~m} .
$$

- Mažos kliūtys:

$$
\begin{aligned}
& L \in[0,05 \mathrm{~m} ; 0,1 \mathrm{~m}], \\
& H \in[0,1 \mathrm{~m} ; 0,12 \mathrm{~m}], \\
& W \in[0 \mathrm{~m} ; 0,08 \mathrm{~m}] .
\end{aligned}
$$

- Vidutinès kliūtys:

$$
\begin{aligned}
& L \in[0,1 \mathrm{~m} ; \infty], \\
& H \in[0,01 \mathrm{~m} ; 0,12 \mathrm{~m}], \\
& W \in[0,08 \mathrm{~m} ; \infty] .
\end{aligned}
$$

- Didelès kliūtys: 


$$
\begin{aligned}
& L \in[0,1 \mathrm{~m} ; \infty], \\
& H \in[0,12 \mathrm{~m} ; \infty], \\
& W \in[0,08 \mathrm{~m} ; \infty] .
\end{aligned}
$$

Fizinio roboto modelio atveju judejimo parametrai šiek tiek skiriasi nuo imitacinio roboto modelio. Judesiai yra apriboti pavaru galimybèmis, kūno ir kojų storiu. Nors judejjimo parametrai judant lygiu paviršiumi išlieka tokie patys, maksimalūs parametrai šiek tiek skiriasi. Roboto storis apriboja žingsnio aukštį, todèl sumažèja maksimalus fizinio roboto žingsnio aukštis. Jis yra lygus $0,1 \mathrm{~m}$. Žingsnio ilgis ir plotis lieka nepakitę.

Gavus šiuos pakeitimus buvo perrašytos kliūčių skirstymo lygtys (2.29)(2.32) realaus šešiakojo roboto atveju:

- Lygus paviršius:

$$
H<0,01 \mathrm{~m} .
$$

- Mažos kliūtys:

$$
\begin{aligned}
& L \in[0,05 \mathrm{~m} ; 0,1 \mathrm{~m}], \\
& H \in[0,01 \mathrm{~m} ; 0,1 \mathrm{~m}], \\
& W \in[0 \mathrm{~m} ; 0,08 \mathrm{~m}] .
\end{aligned}
$$

- Vidutinès kliūtys:

$$
\begin{aligned}
& L \in[0,1 \mathrm{~m} ; \infty], \\
& H \in[0,01 \mathrm{~m} ; 0,1 \mathrm{~m}], \\
& W \in[0,08 \mathrm{~m} ; \infty] .
\end{aligned}
$$

- Didelès kliūtys:

$$
\begin{aligned}
& L \in[0,1 \mathrm{~m}, \infty], \\
& H \in[0,1 \mathrm{~m}, \infty], \\
& W \in[0,08 \mathrm{~m}, \infty] .
\end{aligned}
$$

Realūs ịvairaus dydžio kliūčių pavyzdžiai su nurodytais matmenimis pateikti 2.11 paveiksle.

Toliau buvo nagrinejjamas paviršiaus klasifikavimo modelio sudarymas. Šiame darbe paviršius buvo vertinamas pagal du kriterijus: pagal kliūčių tankị aplinkoje ir pagal kliūčių dydị. Kliūčių tankị nusako atstumas tarp kliūčių $D$. Kliūčių dydị nusako kliūčių aukštis $H$, ilgis $L$ ir plotis $W$. Šiuos kriterijus taip pat galima skaidyti i mažesnes kategorijas. Tyrimuose buvo naudojamos dvi kategorijos kiekvienam kriterijui: mažas kliūčių tankis, didelis kliūčių tankis, mažos kliūtys, didelès kliūtys. Mažą kliūčių tankị nusako atstumas tarp kliūčių centrų. kuris yra $0,15 \mathrm{~m}$ arba didesnis $(D \geq 0,15 \mathrm{~m})$ (2.12 pav. (a)). Dideli kliūčių tankị nusako atstumas tarp kliūčių centrų, kuris yra nuo 0,1 iki $0,15 \mathrm{~m}$ $(0,1 \mathrm{~m} \leq D \leq 0,15 \mathrm{~m})$ (2.12 pav. (b)). Kliūčių dydis nusakomas pagal jų aukštị. 
Mažomis kliūtimis vadinamos tos, kurių aukštis yra tarp 0,03 ir $0,05 \mathrm{~m}$ $(0,03 \mathrm{~m} \leq H \leq 0,05 \mathrm{~m})$, o didelèmis kliūtimis vadinamos tos, kurių aukštis yra tarp 0,06 ir $0,08 \mathrm{~m}(0,06 \mathrm{~m} \leq H \leq 0,08 \mathrm{~m})$. Pastebètina, kad minimalūs ir maksimalūs kliūčių aukščiai nesutampa su šešiakojo roboto trajektorijos parametrais. Taip yra todèl, kad būtų paliktas judejjimo rezervas (robotas galètų aptikti ir ịveikti ịvairaus dydžio kliūtis); taktilinių jutiklių netikslumo kompensavimas.

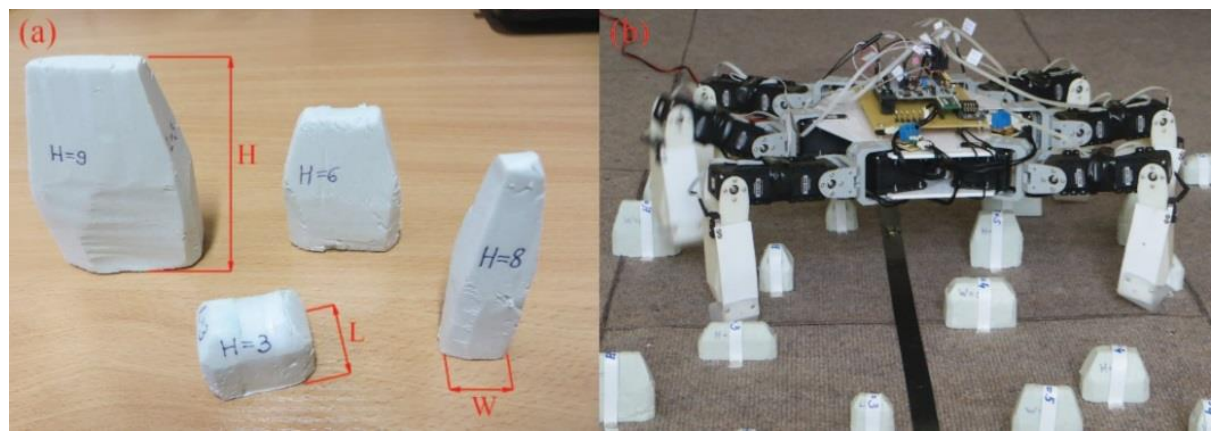

2.11 pav. Ivairaus dydžio kliūčių pavyzdžiai: (a) kliūčių matmenys; (b) kliūčių dydžių palyginimas su šešiakoju robotu

Fig. 2.11. Examples of real different size obstacles: (a) obstacle parameters; (b) obstacle size comparison with hexapod robot

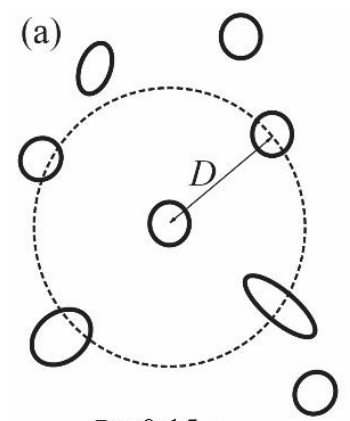

$D \geq 0,15 \mathrm{~m}$

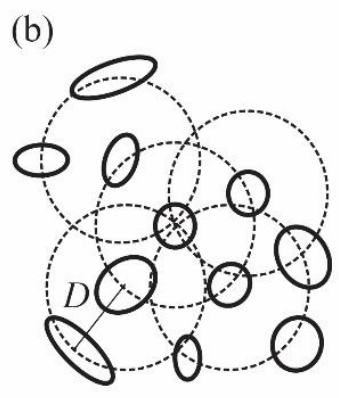

$0,1 \mathrm{~m} \leq D<0,15 \mathrm{~m}$

2.12 pav. Skirtingi kliūčių tankiai: (a) mažas kliūčių tankis; (b) didelis kliūčių tankis

Fig. 2.12. Different obstacle densities: (a) low obstacle density; (b) high obstacle density

Kombinuojant išvardintas kliūčių dydžio ir tankio kategorijas gaunami keturi skirtingi paviršiaus tipai:

- mažas kiekis mažų kliūčių;

- mažas kiekis didelių kliūčių;

- didelis kiekis mažų kliūčių; 
- didelis kiekis didelių kliūčių.

Visos paviršiaus kategorijos pavaizduotos 2.13 paveiksle.

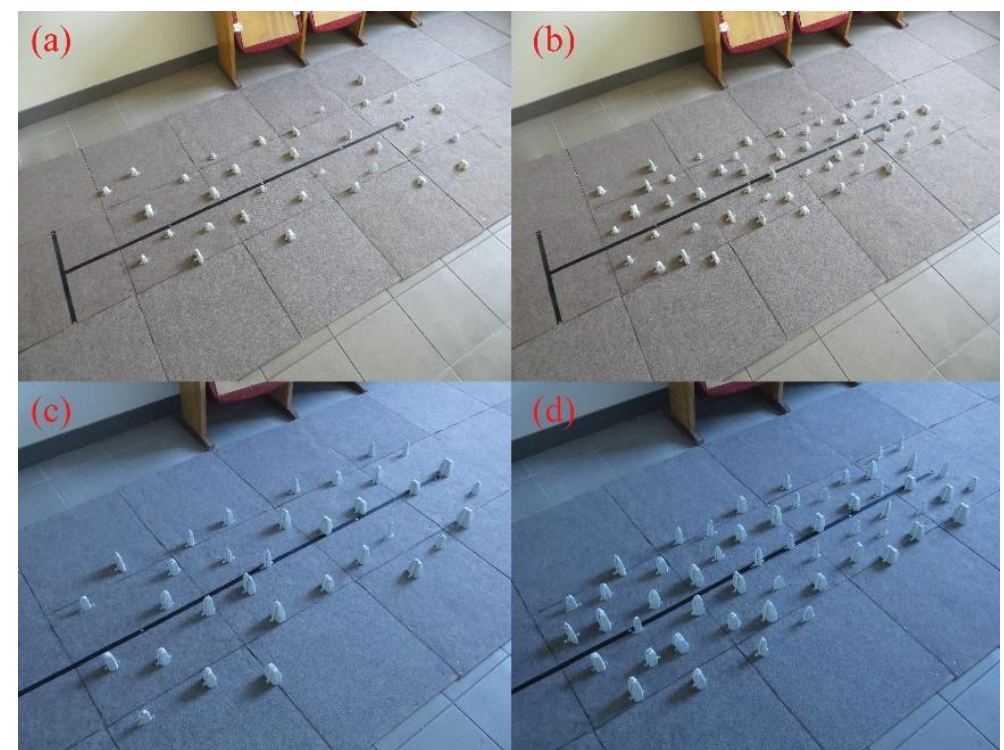

2.13 pav. Skirtingos paviršiaus kategorijos: (a) mažas kiekis mažų kliūčių;

(b) didelis kiekis mažų kliūčių; (c) mažas kiekis didelių kliūčių; (d) didelis kiekis didelių kliüčiu

Fig. 2.13. Different categories of terrain: (a) low density of small obstacles; (b) high density of small obstacles; (c) low density of large obstacles; (d) high density of large obstacles

\subsection{Kliūčių aptikimo ir perlipimo metodų sudarymas}

Paviršiaus atpažinimui ir įvertinimui dažniausiai naudojamos stereo kameros ar lazerinès sistemos. Tačiau norint, kad robotas žinotų, kada koja yra pastatyta ant paviršiaus ar ant kokio paviršiaus robotas eina, galima naudoti ir ívairius jutiklius, sumontuotus tiesiai ant roboto kojų (U. Asif et .al. 2011). Tokiu būdu robotui judant tam tikroje aplinkoje jis gauna informaciją iš jutiklių, kurią realiu laiku gali apdoroti ir panaudoti judejjimo koregavimui. Didelis jutiklių skaičius leidžia tiksliai vertinti paviršiaus tipą.

Kitas populiarus paviršiaus atpažinimo būdas yra jẻgos jutikliai (T. Zhang et. al. 2013) arba kojos standumo matavimo metodas (J. C. Arevalo et. al. 2015). Abu metodai yra gana panašūs, nes yra dinamiški ir naudojantis jais galima nustatyti kojos pastatymo ant paviršiaus momentą, paviršiaus nelygumą bei nustatyti paviršiaus klampumą (paviršiaus tipą). Tokia 
informacija apie paviršių padeda robotams tiksliau judèti nežinomoje aplinkoje, geriau prisitaikyti, todèl robotai gali judèti greičiau ir vykdyti jiems pritaikytas užduotis efektyviau.

Šiame poskyryje pateikiamas šešiakojo roboto kliūčių aptikimo, vertinimo bei pėdos trajektorijos generavimo, skirto kliūčių perlipimui metodų sudarymas. Aptariamas kojų jutiklių kūrimas ir tobulinimas, pedos trajektorijos parametrų parinkimas, o taip pat energijos sąnaudų minimizavimas perlipant kliūtis.

\subsubsection{Kliūčių aptikimas ir ịvertinimas}

Kaip jau minèta skyriaus pradžioje, dauguma robotų paviršiaus nelygumams aptikti naudoja jutiklius ant roboto kojų, pritaisytų pedos apačioje. Šiame darbe tyrimai buvo atliekami robotui perlipant per kliūtis, todèl pèdu jutikliai nèra tinkama priemonè. Kliūčių aptikimui buvo naudojami taktiliniai jutikliai, pritaisyti roboto kojų priekinejje dalyje (2.14 pav.).

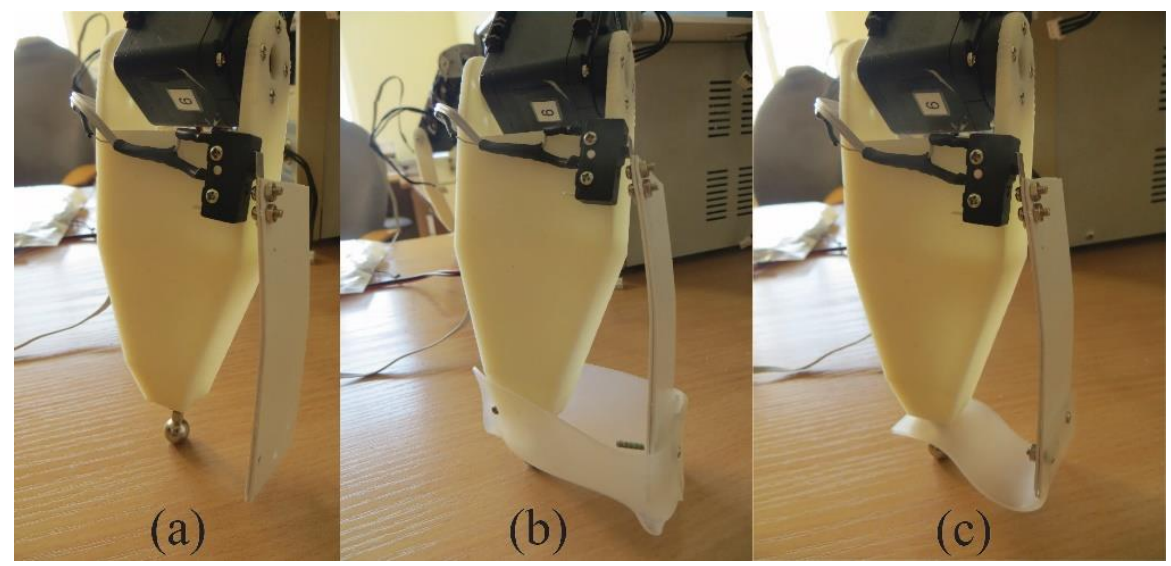

2.14 pav. Taktiliniai roboto kojų jutikliai montuojami ant kojų priekio: (a) pirminẻ versija; (b) antriné versija; (c) galutiné versija

Fig. 2.14. Tactile robot leg sensors attached on leg front side: (a) primary version; (b) secondary version; (c) final version

Buvo išbandytos trys jutiklių versijos (2.14 pav.). Pirmoji versija (2.14 pav. (a)) buvo sukurta naudojant tik taktilinị jutiklį ir jautriosios dalies prailginimą. Taktilinis jutiklis yra galinès padèties jungiklis su metaline svirtele dèl tvirtumo (mikrojungikliai per silpni ir nebuvo galimybès pritvirtinti prailginimų). Prailginimas buvo reikalingas tam, kad robotas bet kuria kojos vieta galètų aptikti kliūtį. Jutiklis buvo pritvirtintas ant roboto blauzdos kojos dalies viršaus, o prailginimas ant jutiklio spaudžiamosios dalies. Prailginančioji dalis buvo stačiakampio formos, kad uždengtų visą kojos priekį. Šios versijos pagrindinis 
trūkumas buvo tai, kad kliūtys užstrigdavo tarp jutiklio prailginančiosios dalies ir kojos, todèl roboto judèjimas buvo sutrukdomas - robotas pradėdavo suktis.

Pirmoji versija buvo patobulinta papildant jutiklio konstrukciją elastine gumine jungtimi tarp roboto pédos ir jutiklio prailginančiosios dalies, suformuojant krepšelio formos uždengimą (2.14 pav. (b)). Tačiau taikant šiuos jutiklius, robotas kojas pastatydavo ant kliūties ne pèda, bet krepšelio dalimi, ir todèl robotas negalèdavo judèti ị priekį.

Galutinè jutiklių versija gauta vietoj krepšelio formos guminès jungties panaudojant plokščią guminę jungti (2.14 pav. (c)). Tokia guminès jungties forma neleisdavo roboto kojoms užstrigti ant kliūčių, o kai kliūtis patekdavo tarp kojos ir jutiklio, koja nuslysdavo nuo kliūties dèl elastinès gumos formos.

Kliūčių aptikimo metodo naudojant taktilinius kojų jutiklius privalumas yra tai, kad robotui nèra reikalinga išankstinè informacija apie kliūčių vietas aplinkoje, tačiau jutikliai nesuteikia informacijos apie kliūčių dydị: ilgị, aukštị ar ploti. Šio darbo pagrindinis tikslas buvo energijos sąnaudų minimizavimas, todèl ši informacija buvo iš anksto ịvedama ị roboto programą.

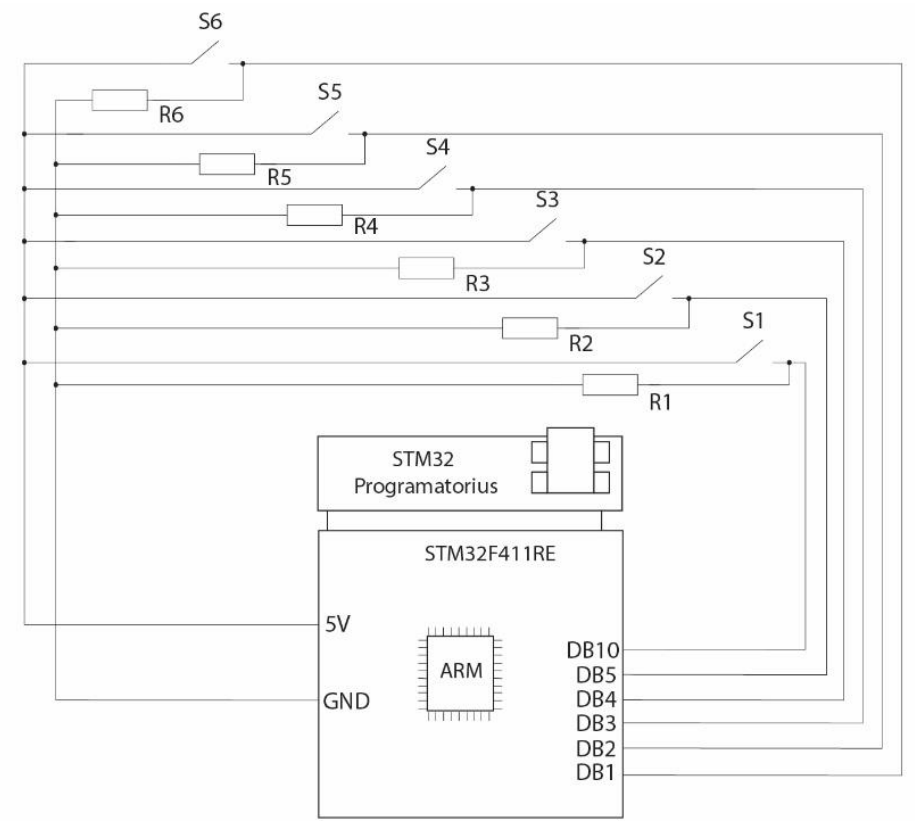

2.15 pav. Taktilinių jutiklių prijungimo schema

Fig. 2.15. The tactile sensor circuit diagram

Taktiliniai kojų jutikliai veikia kaip paprasti mygtukai su neutralų loginị lygi žeminančiuoju rezistoriumi, kurio varža $10 \mathrm{k} \Omega$. Robotas turi šešias kojas, 
todèl jutikliai taip pat buvo naudojami šeši. Visi jutikliai buvo sujungiami su mikrovaldikliu. Principinè jutiklių jungimo elektrinė schema pavaizduota 2.15 paveiksle.

\subsubsection{Pèdos trajektorijos generavimas}

Peddos trajektorijos generavimas buvo nagrinejamas 2.1 poskyryje. Tačiau jis tinka tik roboto judèjimui lygiu paviršiumi. Norint ịveikti kliūtis, pédos trajektorija turi būti keičiama priklausomai nuo kliūties dydžio. Pèdos trajektorijos parametrai taip pat turi būti atitinkamai parenkami norint, kad robotas suvartotų minimalų energijos kiekį. Šiame darbe pėdų trajektorijos generavimas kliūčių perlipimui buvo išskiriamas dviem atvejais: keliant koją per kliūties viršų ir parenkant pėdos trajektorijos parametrus pagal energijos sąnaudas.

Pirmasis atvejis yra žymiai paprastesnis, nes užtenka keisti roboto žingsnio ilgi ir aukštị, norint gauti kliūties perlipimo trajektoriją. 2.16 paveikslas iliustruoja kliūties perlipimo trajektoriją ir pédos trajektorijos generavimą judèjimui lygiu paviršiumi.

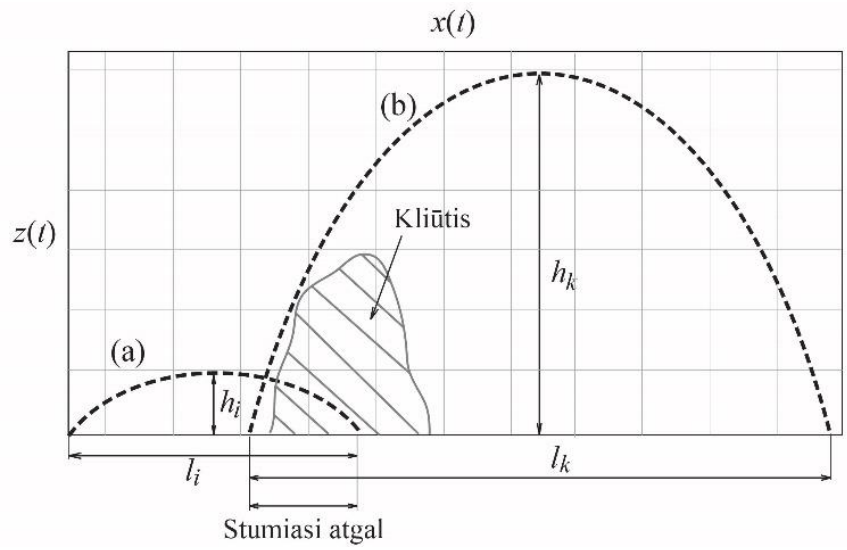

2.16 pav. Skirtingos pèdų trajektorijos: (a) judèjimui lygiu paviršiumi; (b) kliūčių perlipimui keliant koją per kliūties viršu

Fig. 2.16. Different foot trajectories: (a) for locomotion over even terrain; (b) for stepping over the obstacles

Naudojantis 2.16 paveikslu buvo išvestos lygtys, aprašančios abu pėdos trajektorijos generavimo būdus. Kaip jau buvo minèta šio skyriaus pradžioje, norint perlipti kliūtis, reikia keisti žingsnio ilgi ir aukštị. Tai reiškia, kad šie parametrai gali igyti dvi vertes, todèl juos galima išreikšti taip: 


$$
\begin{aligned}
& l=\left\{\begin{array}{l}
l_{\mathrm{i}}, \\
l_{\mathrm{k}},
\end{array}\right. \\
& h=\left\{\begin{array}{l}
h_{\mathrm{i}}, \\
h_{\mathrm{k}},
\end{array}\right.
\end{aligned}
$$

čia $l_{\mathrm{k}}$ ir $h_{\mathrm{k}}-$ kliūties perlipimo žingsnio ilgis ir aukštis atitinkamai. Jie priklauso nuo kliūties dydžio, tačiau nèra lygūs kliūties ilgiui ir aukščiui, nes tuo atveju roboto kojos atsitrenktų ì kliūtis. Tiek žingsnio ilgis, tiek aukštis turi būti didesni, nei priekyje esanti kliūtis. Norint, kad robotas pilnai peržengtu per kliūties viršų i j ją neatsitrenkiant, žingsnio ilgis ir aukštis turi būti išreiškiami taip:

$$
\begin{gathered}
l_{\mathrm{k}}=2 \cdot l_{\mathrm{i}}, \\
h_{\mathrm{k}}=H+0,02 .
\end{gathered}
$$

Kaip matome, kliūties įveikimui žingsnio ilgis turi būti dvigubai didesnis nei pradinis žingsnio ilgis, nes esant mažesniam žingsnio ilgiui, roboto koja užstringa ant kliūties, o žingsnio aukštis turi būti padidintas $0,02 \mathrm{~m}$. Tokie pèdos trajektorijos parametrai kliūties perlipimui buvo gauti po keleto bandymų su šešiakoju robotu, pastebejus, kad esant mažesniam pridètiniam aukščiui, roboto pèda užkliūna už kliūties. Taigi ịstačius lygtis (2.43) ir (2.44) ị (2.41) ir (2.42) galima gauti galutines pėdos trajektorijos generavimo lygtis kliūčiu perlipimui keliant koją per kliūtị:

$$
\begin{aligned}
& l=\left\{\begin{array}{l}
l_{i}, \\
2 \cdot l_{i},
\end{array}\right. \\
& h=\left\{\begin{array}{l}
h_{i}, \\
H+0,02 .
\end{array}\right.
\end{aligned}
$$

Pèdos trajektorijos pakeitimas atliekamas judejimo ciklo pradžioje, nes tik tokiu būdu kliūčių perlipimo metodas veikia tinkamai. Kitu atveju roboto koja yra pastatoma ant kliūties ir roboto judejjimas yra sutrukdomas. Jei roboto kojų jutikliai tampa aktyvūs kojos perkèlimo fazès metu, trajektorija nesikeičia ir žingsnis baigiamas įprastai. Kai viena ar kelios kojos yra kliūties perlipimo fazejje, kitų kojų elgesys nesikeičia. Kliūčių perlipimas nepakeičia kojų perkèlimo cikliškumo, todèl eisenos nepakinta.

Norint ịveikti kliūtị efektyviai, reikia tinkamai parinkti pėdos trajektorijos parametrus. Keliant koją per kliūties viršų ne visada gali reikšti, kad bus suvartojamas minimalus energijos kiekis. Kartais kliūtys gali būti siauresnès ir labai aukštos, todèl koją kelti gali būti patogiau per šoną, nekeliant kojos ị visą kliūties aukštị. Kitais atvejais kliūtys gali būti labai žemos ir labai plačios, todèl koją gali būti patogiau kelti per viršų, nekreipiant kojos ị šoną (2.17 pav.). Tai 
rodo, kad robotas turi galèti keisti pėdos trajektorijos parametrus priklausomai nuo kliūties dydžio. Pèdos trajektorijos generavimą aprašančios (2.24)-(2.26) lygtys nèra tam tinkamas metodas, nes naudodamas toki metodą robotas gali kojas kilnoti tik $z x$ plokštumoje (aukštyn, žemyn ir pirmyn, atgal).

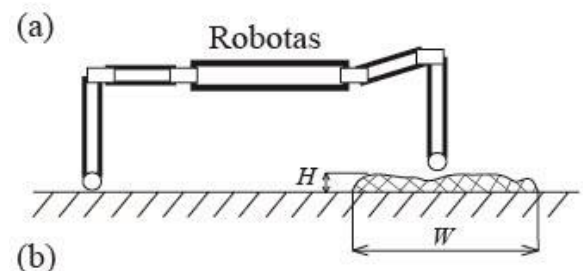

(b)

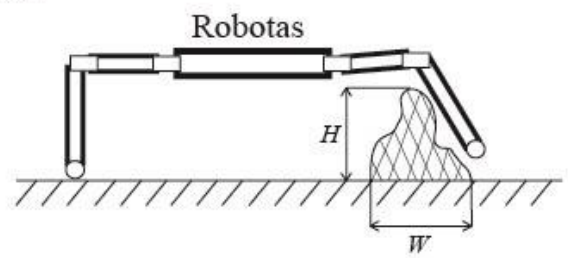

2.17 pav. Skirtingi būdai, naudojami kliūčiu perlipimui: (a) keliant koją per kliūties viršų; (b) keliant koją aplink kliūti

Fig. 2.17. Different ways, used to overcome obstacles: (a) stepping over the obstacle; (b) stepping around the obstacle

Siekiant pagerinti turimas pédos trajektorijos generavimo lygtis buvo pridètas kojos judesys $z y$ plokštumoje. Tam buvo keičiama $y(t)$ priklausomybè. Naują $y(t)$ lygti galima išreikšti taip:

$$
y(t)= \begin{cases}-\sin (\varepsilon) \cdot\left(\frac{l \cdot\left(T-2 \cdot \varphi_{i}+2 \cdot t-1\right)}{2 \cdot(T-1)}+\frac{l}{2}\right), & \text { kai } t \leq \varphi_{i}, \\ \sin (\varepsilon) \cdot\left(l \cdot\left(t-\varphi_{i}\right)\right)+w \cdot \sin \left(\left(t-\varphi_{i}\right) \cdot \pi\right), & \text { kai } \varphi_{i}<t \leq \varphi_{i}+1, \\ \sin (\varepsilon) \cdot\left(\frac{l \cdot\left(T+2 \cdot \varphi_{i}-2 \cdot t+1\right)}{2 \cdot(T-1)}+\frac{l}{2}\right), & \text { kai } t>\varphi_{i}+1,\end{cases}
$$

čia $w$ - žingsnio plotis.

Iš lygčių (2.24), (2.47) ir (2.26) sudaromas pėdų trajektorijų generavimo metodas, skirtas kliūčių perlipimui. Grafiškai priklausomybes nuo laiko atvaizduoti galima taip, kaip parodyta 2.18 paveiksle. Kaip matyti iš paveikslo, tiek $z(t)$, tiek $y(t)$ kinta sinuso dèsniu. Tokiu būdu robotas gali daryti lanką, keldamas koją ne tik per kliūties viršų, bet ir šoną.

Taikant kliūčių perlipimo pėdos trajektorijos generavimo metodą, nèra aišku, kuriuo atveju reikia parinkti kurị generavimo variantą, nes pati trajektorija 
nesuteikia jokios informacijos apie energijos sąnaudas. Todèl darbe taip pat buvo atsižvelgiama ị roboto kojai tenkantị elektros srovès stiprị.

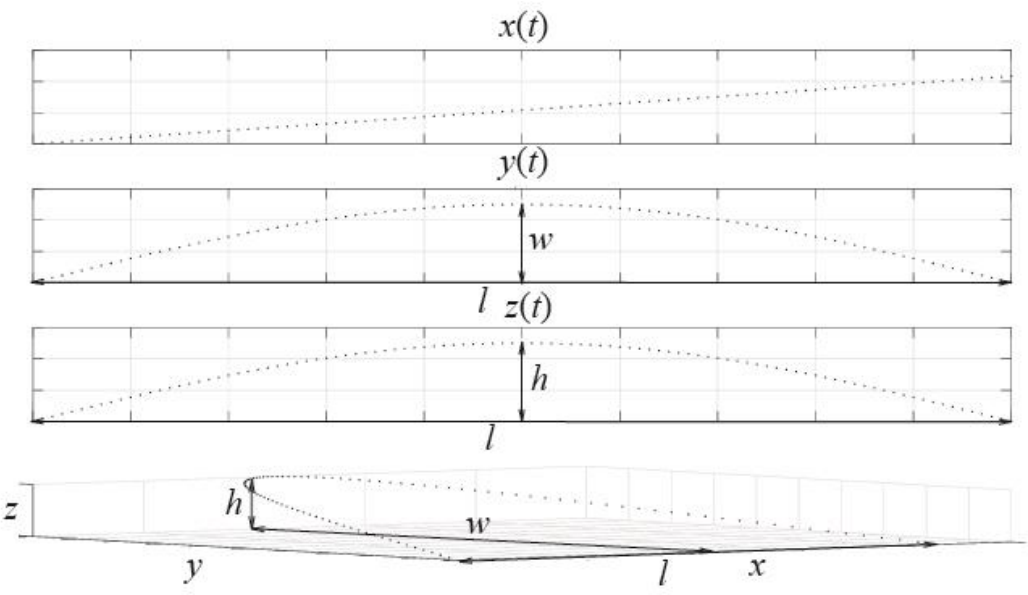

2.18 pav. Pèdos trajektorijos generavimas energetiškai efektyviam kliūčių perlipimui

Fig. 2.18. Foot trajectory generation for energy efficient obstacle avoidance

\subsection{Energijos sąnaudų matematinis modelis}

Norint tinkamai ịvertinti roboto energijos sąnaudas, reikia sudaryti energijos sąnaudų matematinị modelị, kuris leistų nustatyti, kam yra sunaudojama energija ir kokią energiją reikia matuoti. Daugumai robotų naudojamos sukamojo judesio pavaros, todèl išjungus maitinimą jos nelaiko roboto masės, todèl robotas negali stovèti. Taigi energiją robotas naudoja tiek stovėdamas, tiek judèdamas, tačiau abiem atvejais ji veikia skirtingos jègos, kurios ir nusako, kur sunaudojama energija (2.19 pav.).

Kaip matyti iš 2.19 paveikslo, robotą veikiančios jẻgos stovèjimo metu yra svorio jèga $F_{\mathrm{s}}$ ir standumo jèga $F_{\mathrm{d}}$, kuri veikia kiekvieną roboto koją. Judejjimo metu robotą taip pat veikia svorio ir standumo jègos, tačiau atsiranda ir kitos jëgos, tokios kaip traukos jèga $F_{\text {tr }}$, trinties jèga $F_{\mathrm{t}}$, inercijos momentas. Oro pasipriešinimas neturi ịtakos, nes robotas juda lètai. Dar viena priežastis, dèl kurios galètų didèti energijos sąnaudos roboto judejimo metu, yra roboto pèdų smūgiai ì paviršių, kojos pastatymo metu. Tai, žinoma, priklauso nuo daug sąlygu (pvz. paviršiaus, judèjimo greičio, pėdos konstrukcijos), tačiau nustatyta, kad smūgio metu jèga gali siekti iki $\sim 25 \mathrm{~N}$, kai roboto mase yra $\sim 1,5 \mathrm{~kg}$ (M. Luneckas et. al. 2018). 


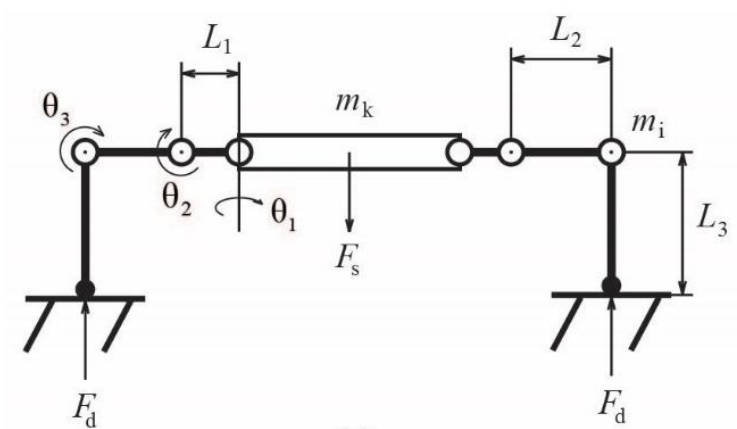

(a)

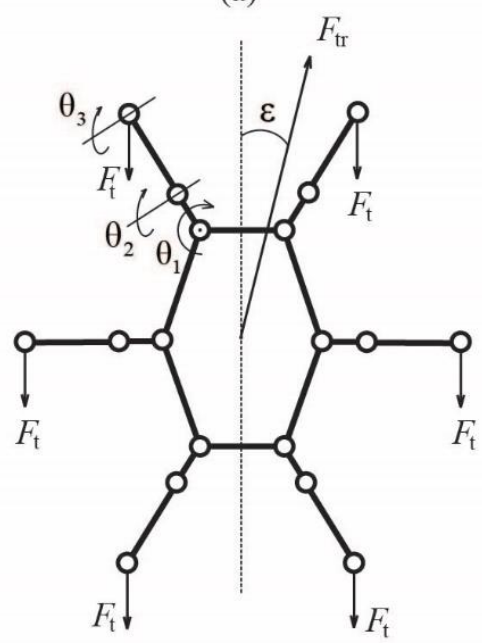

(b)

2.19 pav. Vaikščiojantị robotą veikiančių jègų kinematinis modelis: (a) neutralaus stovèjimo metu; (b) judèjimo metu

Fig. 2.19. Walking robot force kinematic model: (a) during neutral stance;

(b) during movement

Visoms robotą veikiančioms jègoms ịveikti, reikalinga energija, kad robotas galètų stovèti ir judèti. Pilnutinè sistemos mechaninè energija yra lygi potencinès ir kinetinès energijų sumai:

$$
E_{\mathrm{p}}=E_{\mathrm{kin}}+E_{\mathrm{pot}}
$$

čia $E_{\mathrm{p}}$ - pilnutinè sistemos (mechaninè) energija, $E_{\mathrm{kin}}-$ kinetinè sistemos energija, $E_{\text {pot }}$ - potenciné sistemos energija. Kinetinę sistemos energiją išreikšti galima taip:

$$
E_{\text {kin }}=\frac{1}{2} m v^{2}+\frac{1}{2} I \omega^{2},
$$


čia $m$ - sistemos kūno masè, $v$ - kūno tiesinis greitis, $I$ - kūno inercijos momentas, $\omega-$ kūno kampinis greitis. Potencinę sistemos energiją išreikšti galima taip:

$$
E_{\mathrm{pot}}=\frac{1}{2} k x^{2}+m g h,
$$

čia $k$ - sistemos standumo koeficientas, $x$ - kūno pailgejjimas, $g$ - laisvojo kritimo pagreitis, $h-$ kūno aukštis.

Daugumai vaikščiojančių robotų energija reikalinga pavaroms, kurios konstruojamos ant roboto kojų, todèl (2.49) ir (2.50) lygtis galima perrašyti išskaidant energiją atskiroms roboto kojoms:

$$
\begin{aligned}
& E_{\mathrm{kin}}=\sum_{i=1}^{n} \frac{1}{2} m_{i} v_{i}^{2}+\frac{1}{2} I_{i} \omega_{i}^{2}, \\
& E_{\mathrm{pot}}=\sum_{i=1}^{n} \frac{1}{2} k_{i} x_{i}^{2}+m_{i} g h_{i},
\end{aligned}
$$

čia $m_{i}-i$-osios roboto kojos masè, $v_{i}-i$-osios roboto kojos tiesinis greitis, $I_{i}-i$ osios roboto kojos inercijos momentas, $\omega_{i}-i$-osios roboto kojos kampinis greitis, $k_{i}-i$-osios roboto kojos standumo koeficientas, $x_{i}-i$-osios roboto kojos pailgèjimas, $h_{i}-i$-osios roboto kojos aukštis, $n$ - roboto kojų skaičius.

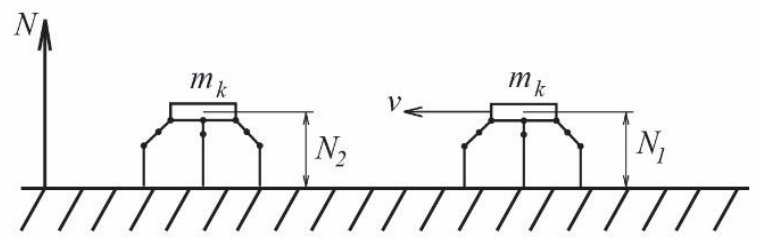

2.20 pav. Vaikščiojančio roboto judejjimas neutralioje padètyje, kai kūno pakèlimo aukštis nekinta

Fig. 2.20. Walking robot locomotion in neutral stance when body elevation is constant

(2.51) ir (2.52) išraiškos nèra tinkamos vaikščiojančio roboto energijos sąnaudoms ịvertinti, nes sistemoje nèra visų sudedamujų, kurios įeina ị lygtis. Visų pirma, darbe naudojamam šešiakojui robotui nèra pritaikyti standumo elementai (pvz. spyruoklès), o ir pačiu roboto kojų standumas galima laikyti yra labai didelis, nes naudojamos netamprios konstrukcinès detalès, todèl pirmasis potencinès energijos narys nèra reikalingas. Taip pat ir antrasis narys nèra reikalingas, nes visuose eksperimentuose roboto judejjimo metu jo kūnas yra visada iškeltas ị tą patị aukšti (2.20 pav.). Tarkime, kad roboto kūno aukštis pradiniame taške yra $N_{1}$, o galiniame taške $-N_{2}$. Potencinès energijos, 
skaičiuojamos pagal išraišką $E_{\text {pot }}=m g\left(N_{2}-N_{1}\right)$, vertė yra lygi 0 . Nors visų 3 skyriuje aprašytų eksperimentų metu roboto kūnas šiek tiek nukrypdavo nuo idealiai horizontalios padèties, šie nukrypimai būdavo tokie maži, kad kūno pakèlimo aukšti buvo galima laikyti nepakitusiu (A. Skaburskytė et. al. 2016).

Taigi matyti, kad vaikščiojančio roboto pilnutinę energiją galima skaičiuoti tik kaip kinetinę energiją:

$$
E_{\mathrm{p}}=E_{\text {kin }}=\sum_{i=1}^{n} \frac{1}{2} m_{i} v_{i}^{2}+\frac{1}{2} I_{i} \omega_{i}^{2} .
$$

Pamatuoti roboto kojų tiesini ar sukamaji greičius ir inercijos momentus nèra paprasta, nes, kaip minèta 2.1 poskyryje, šiame darbe naudojamo šešiakojo roboto pédos trajektorijos nèra tiesinès. Tarp kiekvienų dviejų pédos trajektorijos taškų šie parametrai kinta ir tai komplikuoja jų ịvertinimą darbo metu. Pilnutinę suvartojamą roboto energiją galima ịvertinti ir taikant paprastesni metodą, kuris yra tiek pat tikslus, kaip ir kiti energijos sąnaudų matavimo metodai. Toliau pateikiamas paaiškinimas.

HexaV4 robotui naudojamos tik elektrinès pavaros ir yra naudojamas ittampos šaltinis, todèl pilnutinę mechaninę energiją atitinka elektros energija. HexaV4 robotas yra savo gamybos šešiakojis robotas, todèl elektros energijos matavimas ir skaičiavimas buvo paprasčiausias iš visų energijos matavimo metodų, nes elektros srovès stiprio matavimo schemą buvo galima jungti bet kurioje roboto vietoje.

Žinant, kad robotui reikalinga elektros energija tiek pavaroms, tiek valdymo sistemai, pilnutinę roboto suvartojamos energijos kiekio išraišką galima užrašyti taip:

$$
E_{\mathrm{c}}=E_{\mathrm{v}}+\sum_{i=1}^{n} E_{k i}
$$

čia $E_{c}$ - vieno roboto judejimo ciklo pilnutinè energija, $E_{v}$ - roboto valdymo sistemos suvartojamas energijos kiekis, $E_{k i}$ - vienos roboto kojos visų pavarų suvartojamas energijos kiekis, $n$ - kojų skaičius. Tai yra daug paprastesnis būdas tinkamai ịvertinti vaikščiojančio roboto energijos sąnaudas, todèl darbe ir buvo taikomas šis metodas.

Kaip jau buvo minèta 2.1 poskyryje, šešiakojo roboto valdymo sistemai tenkantis elektros srovès stipris yra pakankamai mažas, kad būtų neįskaičiuojamas tyrimuose, todèl pilnutinè šešiakojo roboto suvartojamos energijos vertė buvo supaprastinta iki tokios išraiškos:

$$
E_{\mathrm{c}}=\sum_{i=1}^{6} E_{k i}
$$


Kaip matoma iš išraiškos (2.55), roboto suvartojamas energijos kiekis labiausiai priklauso tik nuo kojų suvartojamos energijos kiekio, kas prilygsta pavarų suvartojamai energijai.

Vienos kojos suvartojamos energijos kiekis išreiškiamas taip:

$$
E_{k}=P_{k} \cdot t_{k},
$$

čia $P_{k}$ - vienos roboto kojos naudojamos galios kiekis, $t_{k}-$ vienos roboto kojos perkèlimo ciklo laikas. Naudojamos galios kiekis gali būti išreikštas taip:

$$
P_{k}=U \cdot I_{k},
$$

čia $U$ - šaltinio ịtampos vertè, $I_{k}$ - vidutinis roboto kojai tenkantis elektros srovės stipris. Kojos darbo laikas išreiškiamas taip:

$$
t_{k}=\frac{d_{k}}{v_{\text {vid }}},
$$

čia $d_{k}$ - kojos nueitas kelias vieno žingsnio metu, $v_{\text {vid }}-$ vidutinis kojos judejimo greitis. Vidutinis greitis naudojamas dèl paprastumo, nes, iš tikrujų, kojos judejjimo greitis nèra visada vienodas. Pèdos trajektorija nèra tiesinè visuose taškuose, todèl ir greitis kiekviename taške yra skirtingas.

Istačius lygtis (2.56)-(2.58) ị lygti (2.55) gaunama galutinè šešiakojo roboto suvartojamos energijos kiekio išraiška vieno žingsnio metu:

$$
E_{\mathrm{c}}=\sum_{i=1}^{6} U \cdot I_{k} \cdot \frac{d_{k}}{v_{\mathrm{vid}}} \text {. }
$$

Prieš parenkant judejjimo parametrus, buvo išskirti du atvejai. Kojos perkèlimo laikas priklauso nuo roboto judejjimo metodo: roboto kojų judesiai gali būti sinchronizuoti laiko atžvilgiu, kai kiekvienas žingsnis trunka tiek pat laiko, arba kojų judesiai gali būti nesinchronizuoti laiko atžvilgiu, kai kiekvienas žingsnis trunka skirtingą laiko tarpą, priklausomai nuo žingsnio trajektorijos ilgio. Jeigu kojų judesiai nèra sinchronizuoti laiko atžvilgiu, (2.59) išraiška lieka nepakitusi. Tačiau jei kojų judesiai yra sinchronizuoti laiko atžvilgiu, trajektorijos ilgio ir kojos judejimo greičio santykis tampa pastovus:

$$
\frac{d_{k}}{v_{\text {vid }}}=\text { const. }
$$

Abiem atvejais buvo ieškomi žingsnio parametrai, kuriais judedamas robotas suvartoja mažiausią energijos kiekį. Pirmuoju atveju roboto judejjimo metu kito tik pėdos nueitas kelias žingsnio metu $d_{k}$. Buvo siekiama rasti mažiausią parametro vertę, kad roboto energijos sąnaudos būtų mažiausios. Todèl buvo ieškoma trumpiausia žingsnio trajektorijos ilgio vertė:

$$
\arg \underset{w, h, I_{k}}{\min }\left(d_{k}\right) \text {. }
$$


Šiuo atveju vienos kojos energijos sąnaudos priklauso nuo roboto žingsnio aukščio $h$, žingsnio pločio $w$, ir nuo elektros sroves stiprio $I$. Žingsnio aukščio ir pločio apribojimai yra tokie: $w \in[0 ; 0,06] \mathrm{m}$ ir $h \in[0,01 ; 0,1] \mathrm{m}$. Elektros srovès stipris priklauso nuo žingsnio parametrų, todèl ji galima išreikšti kaip funkciją nuo žingsnio aukščio ir pločio:

$$
I_{k}=f(w, h) \text {. }
$$

Siekiant rasti mažiausias judèjimo parametrų vertes pirmuoju atveju, buvo išreikštas pèdos trajektorijos ilgis $d_{k}$. Žinoma, kad roboto judejjimo ciklo metu yra dvi fazės: palaikymo fazė ir perkèlimo fazè. Kiekvienos fazès metu pèdos trajektorijos forma yra skirtinga. Palaikymo fazės metu roboto koja yra pastatyta ant paviršiaus ir juda atgal, todèl palaikymo fazès metu pedos trajektorijos forma yra tiesè. Perkèlimo fazès metu roboto koja juda sinuso formos lanku. Taigi pẻdos trajektorijos ilgị galima išreikšti kaip šių kreivių sumą:

$$
d=l+s,
$$

čia $l$ - tiesès ilgis, $s$ - sinuso lanko ilgis. Tiesès ilgis prilygsta roboto žingsnio ilgiui, kuris yra žinomas dydis, todèl jo išreikšti nereikia. Tačiau sinuso lanko ilgis gali kisti priklausomai nuo kliūčiu dydžių. Standartinè sinuso lanko ilgio išraiška yra tokia:

$$
s=\int_{a}^{b} \sqrt{(d x)^{2}+(d y)^{2}+(d z)^{2}} d x,
$$

čia $d x, d y$ ir $d z$ - erdvès koordinačių kitimas pagal laiką $t$.

Žinant, kad kojos perkèlimui reikalingas tik pusès periodo sinusas, integravimas buvo atliekamas nuo 0 iki $\pi$ intervale. Taip pat žinant, kad kojos perkèlimas vyksta $z y$ plokštumoje, todèl $x$ koordinate išnykta, o integravimas turi būti atliekamas pagal žingsnio ilgi $l$, nes robotas juda $x$ koordinatès kryptimi. Todèl (2.58) lygtis buvo perrašyta atitinkamai:

$$
s=\int_{0}^{\pi} \sqrt{1+(d y)^{2}+(d z)^{2}} d l .
$$

Reikiamos $y$ ir $z$ išraiškos tiesiam judèjimui buvo gautos iš (2.25) ir (2.26) lygčių. Tačiau reikia imti tik tas išraiškas, kai $\varphi_{i}<t \leq \varphi_{i}+1$ nes tada vyksta kojos perkèlimo fazè:

$$
\begin{aligned}
& y=w \cdot \sin \left(\left(t-\varphi_{i}\right) \cdot \pi\right), \\
& z=h \cdot \sin \left(\left(t-\varphi_{i}\right) \cdot \pi\right) .
\end{aligned}
$$

Išvestinių $d y$ ir $d z$ vertès gaunamos diferencijuojant lygtis (2.58) ir (2.59):

$$
\begin{aligned}
& y^{\prime}(t)=\left(\pi \cdot w \cdot \cos \left(\left(\pi \cdot\left(\varphi_{i}-t\right)\right) / 2\right)\right) / 2, \\
& z^{\prime}(t)=\left(\pi \cdot h \cdot \cos \left(\left(\pi \cdot\left(\varphi_{i}-t\right)\right) / 2\right)\right) / 2 .
\end{aligned}
$$

Istačius išraiškas (2.68) ir (2.69) ị lygtị (2.65) ir pakèlus kvadratu gaunama tokia išraiška: 


$$
s=\int_{0}^{\pi} \sqrt{1+\frac{\pi^{2} \cdot w^{2} \cdot \cos ^{2}\left(\left(\varphi_{i}-t\right) \cdot \pi / 2\right)}{4}+\frac{\pi^{2} \cdot h^{2} \cdot \cos ^{2}\left(\left(\varphi_{i}-t\right) \cdot \pi / 2\right)}{4}} d l .
$$

Sutraukus bendruosius narius ir ịstačius išraišką i (2.55) lygtị:

$$
d=l+\int_{0}^{\pi} \sqrt{\frac{4+\pi^{2} \cdot w^{2} \cdot \cos ^{2}\left(\left(\varphi_{i}-t\right) \cdot \pi / 2\right)+\pi^{2} \cdot h^{2} \cdot \cos ^{2}\left(\left(\varphi_{i}-t\right) \cdot \pi / 2\right)}{4}} d l .
$$

(2.71) lygtis yra tikslo funkcija (2.61) lygtimi išreikštam uždaviniui spręsti. Kaip matyti iš tikslo funkcijos, šiam atvejui reikalingi parametrai yra žingsnio ilgis $l$, aukštis $h$, plotis $w$, kojos perkèlimo faze $\varphi_{i}$ ir laikas $t$. Ši lygtis yra galutinè roboto pėdos trajektorijos ilgio išraiška, kuri buvo naudojama parenkant žingsnio parametrus energijos sąnaudų minimizavimui.

Antruoju atveju parametru parinkimas yra paprastesnis, nes kinta tik kojai tenkantis elektros srovès stipris $I_{k}$. Todèl energijos sąnaudų minimizavimui buvo naudojama tokia išraiška:

$$
\arg \underset{w, h}{\min }\left(I_{k}\right) .
$$

(2.72) lygtimi išreikšto parametrų parinkimo uždavinio tikslo funkcijos negalima nusakyti lygtimi, nes nèra žinomas elektros srovès stiprio kitimo dèsnis. Tačiau kaip ir pirmuoju atveju, yra žinoma, kad elektros srovès stipris priklauso nuo žingsnio parametru ((2.62) lygtis), todėl šio parametrų parinkimo apribojimai išlieka tokie patys. Tikslo funkciją (2.72) lygtimi išreikšto parametrų parinkimo uždaviniui atitinka elektros srovès stiprių matrica, padaryta pagal 3.5 lentelę, kuri pateikta 3.3 poskyryje. Kintamieji, kurie ịvedami ị ši parametrų parinkimo uždavinị yra kliūčių aukštis $H$ ir plotis $W$.

Imitacinio šešiakojo roboto modelio atveju šie parametrų parinkimo atvejai tinka be papildomų sąlygų, nes nèra įskaičiuojami kojų atsitrenkimai ị kliūtis. Atliekant tyrimus su fiziniu modeliu, roboto kojoms atsitrenkiant ị kliūtis, roboto judejjimas buvo vèlinamas tam tikrą laiką, nes pèdos trajektorijos pakeitimas vyksta tik žingsnio pradžioje. Lygtis (2.55) tampa nebetinkama roboto energijos sąnaudoms ịvertinti, nes ị laiką, per kurị koja atlieka vieną žingsnị, nèra įskaičiuotas vèlinimas atsitrenkus ì kliūtị. Siekiant tinkamai įvertinti suvartojamos energijos kiekị, buvo nagrinejjamas energijos kiekis, kurị robotas suvartoja nueidamas visą jam duotą atstumą.

Idealiu atveju, pilnutinę energiją galima išreikšti taip:

$$
E_{\mathrm{p}}=P_{\text {vid }} \cdot t_{\mathrm{p}},
$$

čia $E_{\mathrm{p}}-$ pilnutinè energija, $P_{\text {vid }}-$ vidutinè naudojamos galios vertè, $t_{\mathrm{p}}-$ pilnutinis roboto veikimo laikas, kuris išreiškiamas taip: 


$$
t_{p}=\frac{s_{p}}{v},
$$

čia $s_{p}$ - pilnas roboto nueitas kelias, $v$ - roboto judejjimo greitis. Visam atstumui nueiti robotas turi atlikti tam tikrą judejimo ciklų skaičių, todèl išraišką (2.74) galima perrašyti taip:

$$
t_{\mathrm{p}}=S \cdot \frac{l}{v},
$$

čia $S$ - judejjimo ciklų skaičius, $l$ - žingsnio ilgis. İstačius (2.75) lygtị ị (2.73) gaunamas pilnutinès energijos išraiška idealiu atveju (kai robotui atsitrenkiant $i$ kliūtis nèra sugaištama papildomai laiko):

$$
E_{\mathrm{p}}=P_{\mathrm{vid}} \cdot S \cdot \frac{l}{v} .
$$

Tačiau lygtis (2.76) nèra tinkama realioms energijos sąnaudoms įvertinti. Žinant, kad robotas sugaišta tam tikrą laiką atsitrenkdamas ị kliūtis, šią lygtị reikia pakeisti taip:

$$
E_{\mathrm{p}}=P_{\mathrm{vid}} \cdot\left(S \cdot \frac{l}{v}+\Delta t\right)
$$

čia $\Delta t$ - laiko vèlinimas dèl atsitrenkimo ị kliūtis. Šis parametras priklauso nuo judejjimo ciklų skaičiaus su kliūtimis ir roboto kojų skaičiaus, nes vieną kliūtị robotas turès įveikti tiek kartų, kiek jo viename šone yra kojų. Remiantis tuo, laiko užvėlinimo išraišką galima išreikšti taip:

$$
\Delta t=\bar{S} \cdot\left(\Delta t_{1}+\ldots+\Delta t_{n / 2}\right),
$$

čia $\bar{S}-$ judejimo ciklų skaičius su kliūtimis, $\Delta t_{1}+\ldots+\Delta t_{N / 2}-$ atskirų roboto kojų laiko vèlinimas atsitrenkiant ị kiekvieną kliūtį, $n$ - roboto kojų skaičius. $\Delta t_{1}+\ldots$ narius išreikšti galima tik panagrinejjus 2.21 paveikslą.

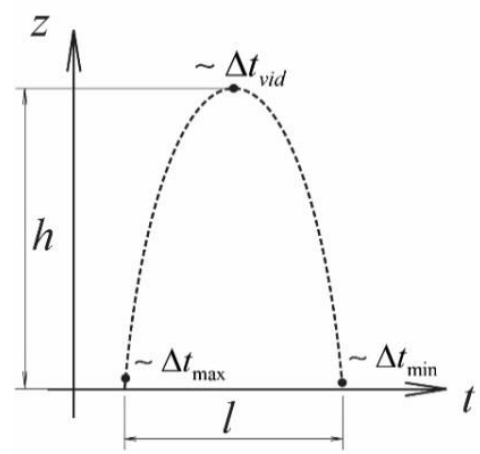

2.21 pav. Pèdos trajektorijos perkèlimo fazès vèlinimo laikai

Fig. 2.21. Foot tajectory transfer phase time delays 
Vèlinimo laikas $\Delta t$ kiekvienai kojai priklauso nuo to, kuriuo metu koja atsitrenks ị kliūtị. I vieną kliūtị koja gali atsitrenkti žingsnio pradžioje ir vẻlinimo laikas bus maksimalus, nes reikès laukti visą kojos perstatymo laiką, kol bus daromas naujas žingsnis. Kitu atveju koja gali atsitrenkti žingsnio gale ir šiuo atveju vèlinimo laikas bus minimalus, nes iš karto bus atliekamas naujas žingsnis. Tačiau pasakyti tikslų kojos atsitrenkimo ì kliūti momentą yra neįmanoma, nes tai priklauso nuo įvairių sąlygų roboto judejjimo metu (pvz. praslydimas, trintis ir t.t.). Todèl norint išreikšti, kam lygus vẻlinimo laikas kiekvienai kojai atskirai, reikia ịvesti kintamajj, kuris sugeneruotu atsitiktinị skaičių tarp 0 ir maksimalaus kojos perkèlimo laiko, tokiu būdu imituojant realų roboto judejjimą. Tada vėlinimo laiko išraiška kiekvienai kojai atrodo taip:

$$
\Delta t_{i}=\operatorname{rand}\left(\frac{l}{v_{\text {vid }}}\right) \text {, }
$$

čia $\Delta t_{i}$ - kojos vėlinimo laikas, rand() - atsitiktinị skaičių generuojanti funkcija nuo 0 iki nurodytos vertès. Kaip matoma iš lygties (2.79), maksimali vélinimo laiko vertè yra pilnas žingsnio atlikimo laikas, kuris randamas padalinant žingsnio ilgi $l$ iš vidutinio kojos judejjimo greičio $v_{v i d}$.

Šešiakojo roboto atveju vienoje roboto pusèje yra trys kojos, todèl lygti (2.78) galima išreikšti taip:

$$
\Delta t=\bar{S} \cdot\left(\Delta t_{P}+\Delta t_{V}+\Delta t_{G}\right),
$$

čia $\Delta t_{P}$ - priekinès kojos vèlinimo laikas, $\Delta t_{V}$ - vidurinès kojos vèlinimo laikas, $\Delta t_{G}-$ galinès kojos vèlinimo laikas. Istačius (2.79) i (2.80) gaunama:

$$
\Delta t=\bar{S} \cdot\left(\operatorname{rand}\left(\frac{l}{v_{\text {vid }}}\right)+\operatorname{rand}\left(\frac{l}{v_{\text {vid }}}\right)+\operatorname{rand}\left(\frac{l}{v_{\text {vid }}}\right)\right) .
$$

Nors lygties (2.81) nariai yra vienodi, sutraukti jų negalima, nes kiekvienos kliūties atveju visoms kojos bus generuojamas visiškai kitas vėlinimo laikas, todèl daugyba iš 3 reikštų, kad visos kojos atsitrenkia ị kliūti tokiu pačiu perkèlimo fazès metu, o to tikimybė yra labai maža. İstačius (2.81) i lygtị (2.77) gaunama galutinè pilnutinès suvartojamos energijos kiekio išraiška šešiakojo roboto atveju:

$$
E_{p}=P_{\text {vid }} \cdot\left(S \cdot \frac{l}{v}+\bar{S} \cdot\left(\operatorname{rand}\left(\frac{l}{v_{\text {vid }}}\right)+\operatorname{rand}\left(\frac{l}{v_{\text {vid }}}\right)+\operatorname{rand}\left(\frac{l}{v_{\text {vid }}}\right)\right)\right) .
$$

Darbe taip pat buvo vertinamas šešiakojo roboto energetinis efektyvumas skaičiuojant transportavimo kaštus pagal šią išraišką: 


$$
C O T=\frac{P}{m g v} .
$$

Ši informacija buvo vertinga nustatant bendrą vaikščiojančio roboto efektyvumą ir lyginti gautus rezultatus su kitais šešiakojais vaikščiojančiais robotais ir mikro robotais. Tai leido tinkamai įvertinti sukurtų metodų efektyvumą.

\subsection{Antrojo skyriaus išvados}

1. Šešiakojo vaikščiojančio roboto kinematinis modelis sudarytas taikant Denavito-Hartenbergo ir atvirkštinès kinematikos skaičiavimo geometriniu būdu vienai kojai metodus. Taikant kelis skirtingus metodus roboto kinematinio modelio sudarymui galima patikrinti sudaryto modelio adekvatumą.

2. Šešiakojo roboto imitacinis modelis sudarytas MATLAB $^{\circledR}$ programos aplinkoje. Naudojant sudarytą modeli galima patikrinti roboto judejjimą įvairiose aplinkose, o taip pat galima patikrinti visų sukurtų metodų veikimą įvairiomis sąlygomis.

3. Patobulinti pėdų trajektorijų generavimo ir eisenų metodai leidžia realiu laiku valdyti vaikščiojantị robotą jam judant lygiu paviršiumi. Šie metodai gali būti naudojami roboto žingsnio ilgiui, aukščiui, judejjimo greičiui bei krypčiai keisti.

4. Sudarytas kliūčių ir paviršiaus tipo klasifikavimo modelis gali būti naudojamas atskirti paviršiaus nelygumus nuo kliūčių ir suskirstyti kliūtis ị atskiras kategorijas atsižvelgiant ị kliūčiu dydị pagal roboto galimybes bei kliūčių dydị ir tankị aplinkoje. Kliūčių skirstymas ị kategorijas pagal jų dydi leidžia parinkti metodus jų ịveikimui.

5. Kliūčių aptikimo ir vertinimo metodas sudarytas naudojant taktilinius jutiklius ir elastinius prailginimus ant roboto kojų priekių. Šis metodas gali būti naudojamas robotui atpažinti priekyje esančias kliūtis kojomis prisilietus prie jų.

6. Sudarytas kliūčių perlipimo metodas keičiant pedų trajektorijos generavimo metodą. Trajektorijos generavimo metodas yra naujas būdas robotui perlipti per ịvairaus žinomo dydžio kliūtis keičiant žingsnio parametrus, tokius kaip žingsnio aukštis ir ilgis. Naudojant ši 
metodą vaikščiojantis robotas gali efektyviai ịveikti visas prieš ji esančias mažo dydžio kliūtis. Sukurtas metodas yra bendras ir todèl tinkamas bet kokiems vaikščiojantiems robotams.

7. Efektyviam kliūčių perlipimui pėdos trajektorijos generavimo metodas buvo papildytas žingsnio pločio parametru, naudojant kurị robotas gali kelti koją ne tik per kliūties viršų, bet ir per šoną. Šis pèdos trajektorijos generavimo metodas gali būti naudojamas parinkti energetiškai efektyviausius kojos perkèlimo parametrus.

8. Sudarytas matematinis modelis energijos sąnaudų skaičiavimui robotui judant paviršiumi su skirtingo dydžio ir tankio kliūtimis. Modelyje ịvertinamas vèlinimo laikas, kuris atsiranda robotui atsitrenkiant ị kliūtis. Šis modelis gali būti naudojamas įvertinti pilną roboto suvartojamą energijos kieki ir patikrinti energijos sąnaudų priklausomybę nuo kliūčių dydžių ir tankio aplinkoje. 



\section{Šešiakojo roboto energetinio efektyvumo tyrimai}

Šio tyrimo tikslas yra ištirti vaikščiojančio roboto energetinị efektyvumą judant lygiu paviršiumi skirtingomis eisenomis, ịvertinti energijos sąnaudų minimizavimo metodo efektyvumą robotui judant per kliūtis, ištirti energijos sąnaudų priklausomybę nuo kliūčių dydžio ir tankio.

Šiame skyriuje pateikiami vaikščiojančio roboto judejjimo lygiu paviršiumi be kliūčių ir su kliūtimis energetinio efektyvumo tyrimų rezultatai. Energetinis efektyvumas judant lygiu paviršiumi nustatomas keičiant eisenas bei judejimo greiti. Roboto judėjimas per kliūtis vertinamas pagal nuokrypius nuo numatytos judejjimo trajektorijos bei kaip tiksliai robotas pasiekia galinị tašką. Taip pat pateikiamas šešiakojo roboto energetinio efektyvumo tyrimų rezultatai taikant pèdos trajektorijos keitimo metodą ir energijos sąnaudų priklausomybė nuo kliūčių dydžio ir tankio.

Skyriaus tematika paskelbti trys autoriaus straipsniai (M. Luneckas, T. Luneckas 2014; M. Luneckas, T. Luneckas, V. Gavelis, V. Valaitis, D. Udris 2015; M. Luneckas, T. Luneckas, D. Udris 2018). 


\section{1. Šešiakojo roboto energetinio efektyvumo judant lygiu paviršiumi tyrimas}

Prieš tiriant roboto energijos sąnaudas judejjimo metu, svarbu įvertinti, kiek energijos robotas suvartoja stovedamas vietoje. Tai leis nustatyti, roboto sunaudojamą energijos kieki vaikščiojimui. Šis tyrimas plačiau aprašytas šaltinyje (M. Luneckas et. al. 2013). Buvo nustatyta, kad robotui stovint ant visų šešių kojų, vidutinis elektros srovès stipris lygus $734 \mathrm{~mA}$, o stovint ant trijų koju - $792 \mathrm{~mA}$. Žinant, kad roboto maitinimo ịtampa lygi $11 \mathrm{~V}$, gaunama, kad šešiakojo roboto vartojama galia stovint ant šešių ir trijų kojų yra $\sim 8 \mathrm{~W}$ ir $\sim 9 \mathrm{~W}$. Šie rezultatai įrodo, kad roboto išlaikymui stacionarioje padètyje, reikalinga energija.

Ankstesniuose vaikščiojančio roboto judejimo lygiu paviršiumi tyrimuose pastebėta, kad roboto energetini efektyvumą stipriai itakojama eisenos bei judejjimo greitis (M. Luneckas et. al. 2014). Šiame skyriuje aprašomas tyrimas, kurio tikslas yra nustatyti, kiek padideja roboto energijos sąnaudos lyginant energijos sąnaudas stovejjimo ir judèjimo metu. Taip pat svarbu yra surasti sąryši tarp energijos sąnaudu ir roboto judejjimo greičio bei eisenos, o taip pat sukurti algoritmą, naudojant kurị būtų galima parinkti esamomis sąlygomis minimalų energijos kiekị suvartojančią roboto eiseną.

Šešiakojo roboto energetinio efektyvumo tyrimui atlikti buvo naudojamas oscilografas, prijungtas prie elektros srovès stiprio matavimo schemos. Roboto pavaroms tenkančio elektros srovès stiprio matavimo funkcinė schema parodyta 3.1 paveiksle.

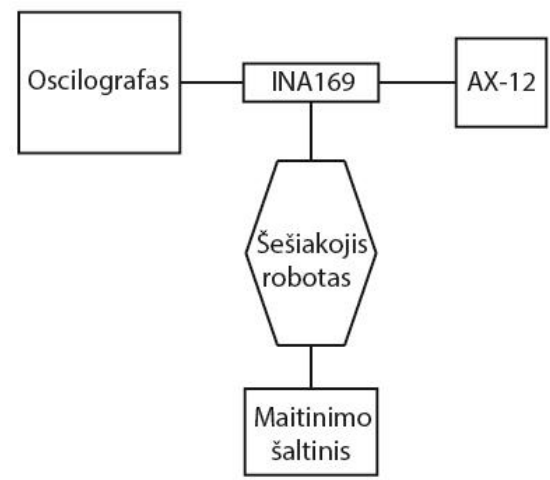

3.1 pav. Šešiakojui robotui tenkančio elektros srovès stiprio matavimo funkcinė schema

Fig. 3.1. Hexapod robot current consumption measurement diagram

Siekiant užtikrinti roboto stabilų judėjimą ir išvengti kojų praslydimų ant paviršiaus, visi eksperimentai buvo atlikti ant minkšto paviršiaus (3.2 pav.). 
Tokiu būdu robotas visada nueidavo numatytą atstumą per tą patị laiką, ir taip būdavo užtikrinamas matavimų vienodumas.

Norint apskaičiuoti roboto vidutinę galios vertę naudojant (2.49) lygtị, reikia įvertinti roboto pavarų vidutinị elektros srovès stiprị $I_{\text {vid. Iprastai vidutinis }}$ elektros srovès stipris gali būti apskaičiuojamas pagal šią išraišką:

$$
I_{\text {vid }}=\frac{1}{t_{2}-t_{1}} \int_{t_{1}}^{t_{2}} I(t) d t,
$$

čia $t_{1}$ ir $t_{2}$ - elektros srovès stiprio matavimo laiko intervalo vertès, $I(t)$ - elektros srovès stiprio kitimo dèsnis laiko atžvilgiu.

Matuojant robotui tenkantị elektros srovès stiprị elektros srovès stiprio kitimo dèsnis nèra žinomas, todèl vidutinis elektros srovès stipris apskaičiuojama taip:

$$
I_{\text {vid }}=\frac{I_{1}+I_{2}+\ldots+I_{j}}{j},
$$

čia $I_{1}, I_{2}, \ldots, I_{j}-$ momentinès elektros srovès stiprio vertès, $j$ - momentinių verčių skaičius.

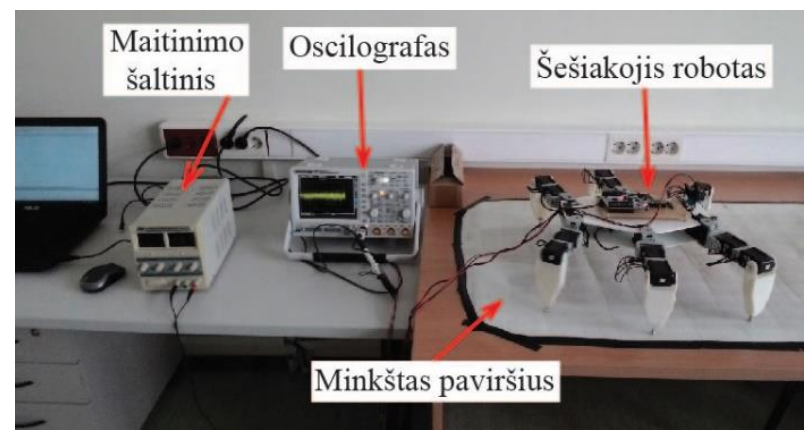

3.2 pav. Šešiakojui robotui tenkančio elektros srovès stiprio matavimo ịranga

Fig. 3.2. Hexapod robot current consumption measurement equipment

Kiekvieno matavimo trukmè buvo $3 \mathrm{~s}$. Toks trumpas laikas buvo pasirinktas dèl kelių priežasčių. Visų pirma, buvo naudojamos ịtampos šaltinis, kuris prie roboto buvo prijungtas laidu. Laido ilgis turèjo būti mažas, nes kuo ilgesnis laidas, tuo didesnè jo varža. Per didelè laido varža galètų stipriai įtakoti elektros srovès stiprio matavimus ir būtų nustatytos neteisingos roboto energijos sąnaudos. Kita priežastis buvo tai, kad robotui judant didesniu greičiu, robotas nukrypdavo ị šoną ir nulipdavo nuo minkšto paviršiaus, o judant skirtingais paviršiaus tipais, roboto kojos remiasi i paviršių skirtinga jèga, ko pasékoje taipogi būtų nustatytos neteisingos roboto energijos sąnaudos. Per $3 \mathrm{~s}$ oscilografas išmatuodavo 6000 robotui tenkančių elektros srovès stiprio verčių. 
Taigi šių eksperimentų metu tarp kiekvienos išmatuotos momentinès elektros srovès stiprio vertès buvo $0,5 \mathrm{~ms}$. Toks laikas tarp elektros srovès stiprio verčių yra adekvatus, todèl galima teigti, kad robotui tenkantis elektros srovès stipris buvo matuojamas tinkamai. Kiekvienas matavimas buvo kartojamas 3 kartus, kad užtikrinti vidutinès vertès stabilumą. Kai kuriais atvejais tekdavo matuoti ir 4 ar 5 kartus, kad būtų gaunami tik tinkamiausi matavimai, o blogi rezultatai buvo atmetami ir skaičiavimuose nenaudojami.

Visų pirma buvo atlikti robotui tenkančio elektros srovès stiprio matavimai prie įvairių judèjimo greičių naudojant keturias pagrindines šešiakojų eisenas: trikoję, dvikoję, banguojančią ir pulsuojančią. Šie matavimai buvo skirti tam, kad nustatyti, prie kokio judejjimo greičio ir eisenos robotui tenka mažiausias elektros srovès stipris, nes būtent nuo šio parametro priklauso energijos sąnaudos (2.4 poskyris). Skirtingos eisenos pasižymi skirtingais greičių diapazonais, todèl buvo matuojami roboto judejimo greičiai. Roboto greitis buvo keičiamas keičiant servo pavarų greičius bei žingsnio trajektorijos ilgị. Greičio nustatymas buvo atliekamas matuojant laiką, per kurị robotas nukeliauja duodą atstumą; atstumas buvo užduodamas skirtingas ir priklausė nuo roboto eisenos bei judejimo greičio. Atlikus greičio matavimus, toliau buvo atliekami robotui tenkančio elektros srovès stiprio eksperimentai pagal 3.1 paveiksle pateiktą schemą. Robotui tenkančio elektros srovès stiprio priklausomybė nuo judejjimo greičio pavaizduota 3.3 paveiksle. Nors, kaip matyti iš 3.3 paveikslo, kai kuriomis eisenomis judant, roboto greitis yra labai mažas, jis vis tiek buvo tinkamas eksperimentuose, nes mažas greitis leido patikrinti sąryṣ̌ tarp roboto energijos sąnaudų stovint ir žingsniuojant.

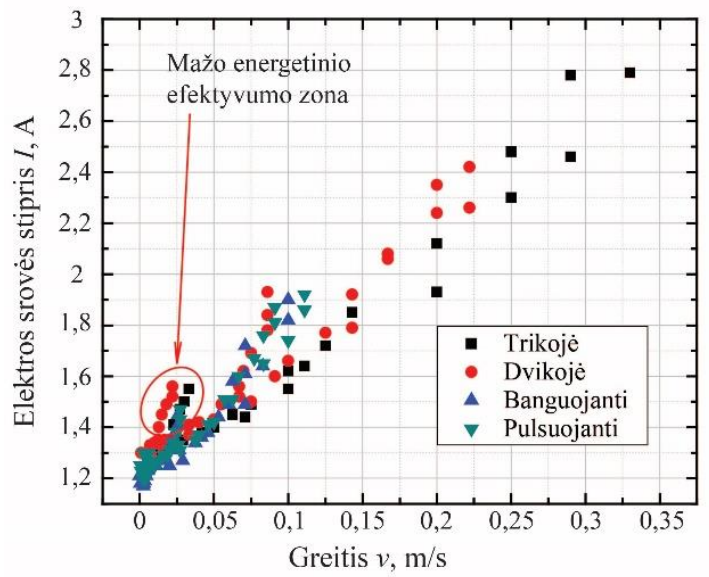

3.3 pav. Robotui tenkančios elektros srovès stiprio priklausomybè nuo judėjimo greičio ir eisenos

Fig. 3.3. Robot current consumption dependence on movement speed and gait 
Iš rezultatų, kurie pavaizduoti 3.3 paveiksle, buvo nustatyta, kad visos eisenos skiriasi greičio diapazonu, kuris priklauso nuo žingsnio trajektorijos ilgio bei servo pavarų sukimosi greičio. Trikojè eisena pasižymi didžiausiu greičiu, kuris siekia $0,33 \mathrm{~m} / \mathrm{s}$, tuo tarpu mažiausią judèjimo greiti pasiekti robotas gali judėdamas banguojančia eisena. Nors banguojanti ir pulsuojanti eisenos turi labai panašų greičių diapazoną, šios eisenos vis tiek buvo pasirinktos taikyti eksperimentų metu dèl didesnio duomenų kiekio. Elektros srovès stiprio priklausomybès nuo judējimo greičio rezultatai taip pat parodo, kad ne visos žingsnio ilgio ir pavarų greičių kombinacijos duoda energetiškai efektyvų rezultatą, nes elektros srovès stipris staigiai išauga. Dél šios priežasties darbe buvo naudojamos tik tos kombinacijos, kurias naudojant buvo gaunamos mažiausios elektros srovès stiprio vertès.

Vidutinès galios priklausomybė nuo roboto eisenos ir greičio buvo perskaičiuojama naudojant 3.3 paveiksle parodytus duomenis. Rezultatas, kuris yra pateiktas 3.4 paveiksle, parodo, kad nei dvikojè, nei pulsuojanti eisenos nèra energetiškai efektyvios visame greičiu diapazone. Tik judant banguojančia eisena mažais greičiais (nuo 0 iki $0,046 \mathrm{~m} / \mathrm{s}$ ) ir judant trikoje eisena dideliais greičiais (nuo 0,046 iki $0,33 \mathrm{~m} / \mathrm{s}$ ) robotas suvartoja mažiausią energijos kiekị.

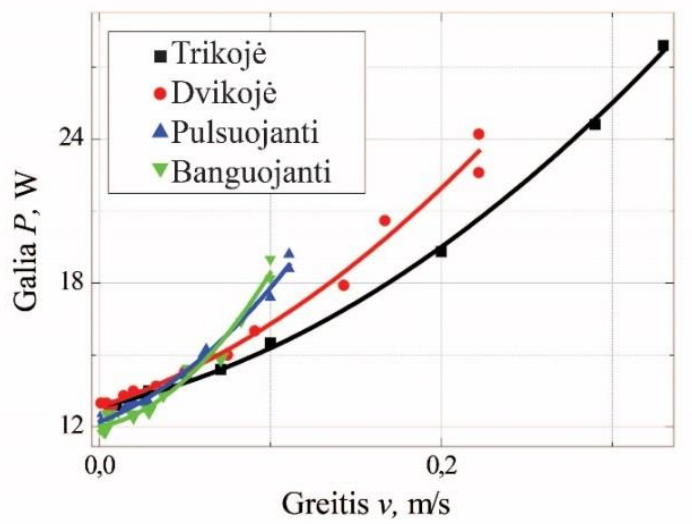

3.4 pav. Šešiakojo roboto vidutinès galios priklausomybè nuo eisenos ir greičio

Fig. 3.4. Hexapod robot average power consumption dependence on gait and speed

Iš 3.5 paveiksle pateikto grafiko buvo nustatytas eisenos keitimo greitis, pritaikius eksponentinị aproksimavimą. Toks aproksimavimo būdas grindžiamas tuo, kad esant dideliems roboto judejimo greičiams, servo pavaros taip pat juda dideliais greičiais. Pavaroms judant greičiais artimais maksimaliems, stipriai padidèja elektros srovès stipris. Iš gautų rezultatų nustatyta, kad eisenos keitimo 
greitis yra $0,046 \mathrm{~m} / \mathrm{s}$, pasiekus kurị, robotas turi pakeisti banguojančią eiseną i trikoję, norint išlaikyti minimalų suvartojamos energijos kiekị.

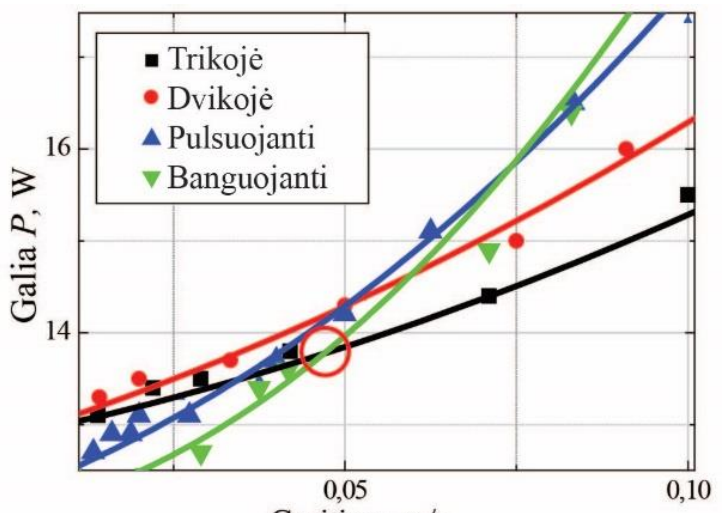

Greitis $v, \mathrm{~m} / \mathrm{s}$

3.5 pav. Šešiakojo roboto vidutinès galios priklausomybè nuo eisenos ir greičio; išdidinta kreivių susikirtimo zona

Fig. 3.5. Hexapod robot average power consumption dependence on gait and speed; enlarged curve intersection zone

Siekiant įvertinti roboto energetinị efektyvumą, buvo apskaičiuotos teorinès energijos sąnaudos pagal lygtis (2.47) ir (2.48). Buvo pasirinkta, kad roboto veikimo laikas yra $1 \mathrm{~h}(3600 \mathrm{~s})$. Judejjimo greitis iš pradžių parinktas $v=0,02 \mathrm{~m} / \mathrm{s}$, o véliau $-v=0,1 \mathrm{~m} / \mathrm{s}$. Naudojantis gautais duomenimis buvo apskaičiuotos šešiakojo roboto energijos sąnaudos visoms eisenoms. Rezultatai pateikti 3.1 lentelèje.

3.1 lentelè. Teorinės šešiakojo roboto energijos sąnaudos skirtingoms eisenoms, kai darbo laikas 1 val.

Table 3.1. Theoretical hexapod robot energy consumption for different gaits, when working time $1 \mathrm{~h}$

\begin{tabular}{|c|c|c|c|c|}
\hline \multirow{2}{*}{ Greitis, m/s } & \multicolumn{4}{|c|}{ Eisenos } \\
\cline { 2 - 5 } & Trikojè & Dvikojè & Pulsuojanti & Banguojanti \\
\cline { 2 - 5 } & \multicolumn{4}{|c|}{$E, \mathrm{~kJ}$} \\
\hline 0,02 & 47,5 & 54 & 47,2 & 45 \\
\hline 0,1 & 55,8 & 59,8 & 62,6 & 65,5 \\
\hline
\end{tabular}

Energijos sąnaudų skirtumai tarp trikojès ir dvikojès eisenų ir skirtumai tarp banguojančios ir trikojès eisenų gali kisti nuo 2,5 iki 9,7 kJ šiam atvejui (3.1 lentelè). Tačiau atsižvelgus ị 3.5 paveikslą, skirtumai tarp šių eisenų gali būti nuo 1 iki $4 \mathrm{~W}$. Tai parodo, kad parenkant tinkamą eiseną priklausomai nuo roboto judejjimo greičio, galima pasiekti, kad robotas suvartos 7,7-21\% mažesni 
energijos kiekį. Nors toks efektyvumas gali atrodyti mažas, tačiau jei roboto veikimo laikas būtų didesnis, šis skirtumas turètų didesnę ịtaką roboto veikimui.

Siekiant užtikrinti, kad toks skirtingų eisenų efektyvumas yra teisingas, eksperimentas buvo pakartotas su papildoma apkrova ant roboto (3.6 pav.). Buvo naudojamos papildomos 1,16 kg ir 2,9 kg masės apkrovos. Pirmosios apkrovos santykis su roboto mase yra $\sim 0,77$, o antrosios $-\sim 1,93$. Gauti rezultatai pavaizduoti 3.7 paveiksle. Kaip matyti, visos skirtingu eisenu kreivès yra išsidèsčiusios taip pat, kaip be apkrovos, tačiau eisenos keitimo greitis pasislenka ị kairę pusę prie $1,16 \mathrm{~kg}$ apkrovos $(v=0,028 \mathrm{~m} / \mathrm{s})$. Tik esant $2,9 \mathrm{~kg}$ apkrovai kreivių padètis pradeda kisti ir kreivių susikirtimo taškas pradingsta. Tačiau visais atvejais tiek dvikojè, tiek pulsuojanti eisenos nèra energetiškai efektyvios. Tai ịrodo, kad banguojanti ir trikojè eisenos išlieka tinkamiausios eisenos prie mažų ir didelių greičių esant skirtingoms sąlygoms, kad robotas suvartotų mažiausią energijos kiekį (3.7 pav.).

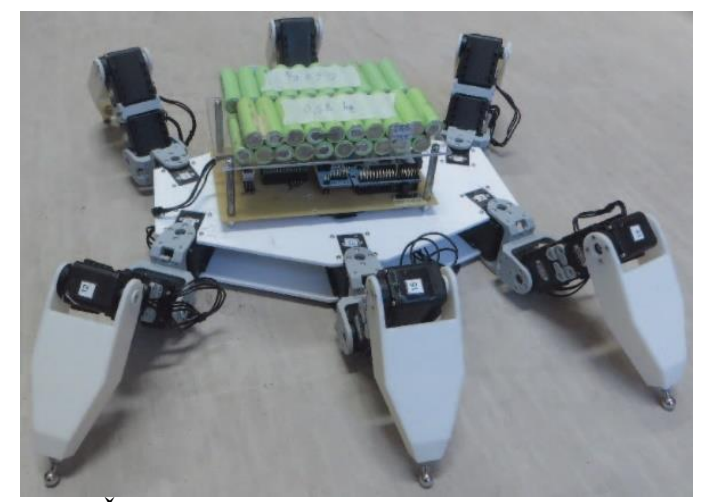

3.6 pav. Šešiakojis robotas su papildoma apkrova

Fig. 3.6. Hexapod robot with additional load

Norint tinkamai ịvertinti roboto energetinį efektyvumą, o taip pat nustatyti darbo zoną bei palyginti energijos sąnaudas su kitų esamų vaikščiojančių robotų energetiniu efektyvumu, transportavimo kaštai buvo apskaičiuoti pagal (2.75) lygtị. Transportavimo kaštai parodo, koks energijos kiekis yra reikalingas, norint perkelti tam tikros masès kūną tam tikru atstumu. Vien vidutiné galios vertė neparodo nieko apie roboto judejjimą skirtingais atstumais esant skirtingiems greičiams. Nèra žinoma, ar nukeliauti mažą atstumą efektyviau dideliu greičiu, ar mažu, taip pat nèra žinoma, kokiu greičiu yra efektyviau nukeliauti didelị atstumą. I transportavimo kaštus taip pat ịskaičiuojama roboto masé, kuri turi didelę įtaka bendram roboto energetiniam efektyvumui. 


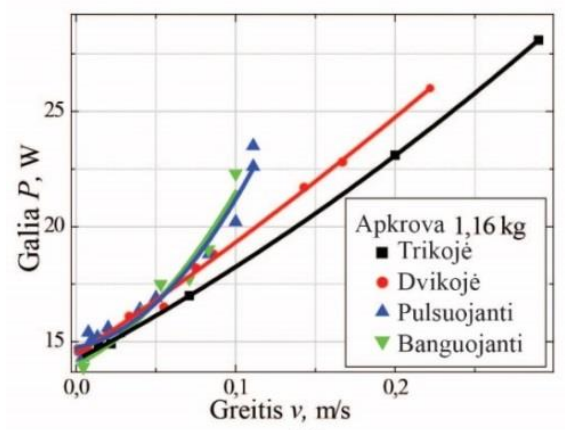

(a)

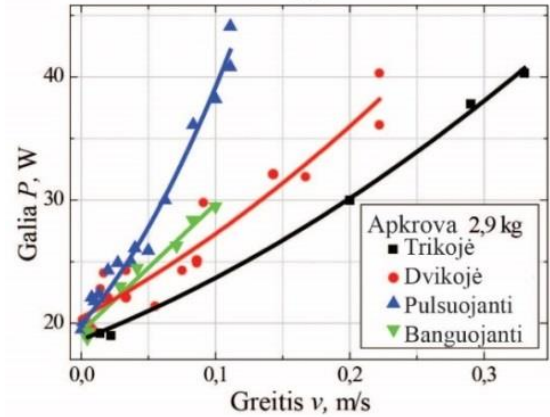

(b)

3.7 pav. Šešiakojo roboto vidutinès galios priklausomybė nuo eisenos ir greičio esant skirtingoms apkrovoms: (a) 1,16 kg apkrovai; (b) 2,9 kg apkrovai

Fig.3.7. Hexapod robot average power consumption dependence on gait and speed at different loads: (a) $1.16 \mathrm{~kg}$ load; (b) $2.9 \mathrm{~kg}$ load

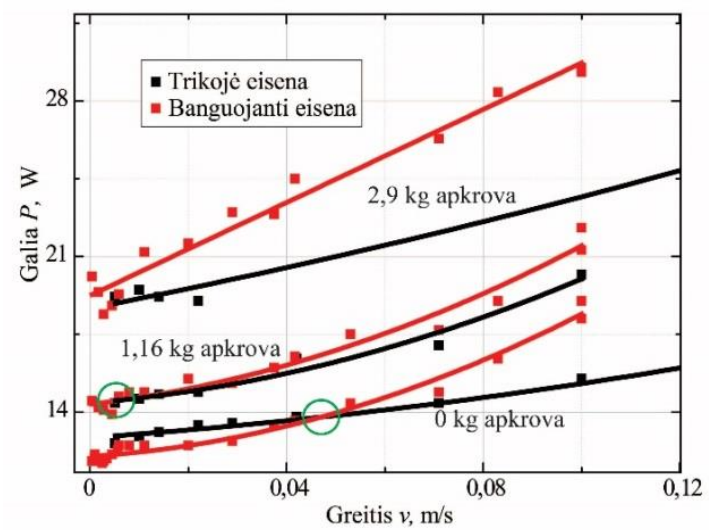

3.8 pav. Šešiakojo roboto vidutinès galios priklausomybès nuo trikojès ir banguojančios eisenos bei greičiu prie skirtingų apkrovų

Fig. 3.8. Hexapod robot average power consumption dependence on tripod and wave gaits and speed at different loads 
Gauti šešiakojo roboto transportavimo kaštų priklausomybès nuo greičio rezultatai pavaizduoti 3.9 paveiksle. Iš 3.9 paveikslo matyti, kad transportavimo kaštai skirtingoms eisenoms keičiasi vienodai keičiantis roboto eisenoms ir greičiams. Vienintelis skirtumas yra tai, kad skirtingomis eisenomis galima pasiekti skirtingus greičius. Iš gauto rezultato buvo nustatyta, kad šešiakojo roboto judèjimas tampa energetiškai efektyvus, kai robotas juda ne mažesniu kaip $0,04 \mathrm{~m} / \mathrm{s}$ greičiu. Taip yra dèl to, kad tame intervale transportavimo kaštų vertės yra mažiausios. Tarp greičių $0,04 \mathrm{~m} / \mathrm{s}$ ir $0,33 \mathrm{~m} / \mathrm{s}$ transportavimo kaštų vertė nukrenta nuo $\sim 25 \mathrm{iki} \sim 5,75$. Tuo tarpu tarp greičių $0,04 \mathrm{~m} / \mathrm{s}$ ir $0,00042 \mathrm{~m} / \mathrm{s}$ transportavimo kaštų verte pakyla nuo $\sim 25$ iki $~ 2000$. Taip yra dèl to, kad robotas vartoja energiją ir stovėdamas vietoje. Taip pat buvo nustatyta, kad trikojè eisena yra efektyviausia ne vien dèl to, kad robotas judedamas trikoje eisena suvartoja mažiausią energijos kiekį, tačiau ir dėl to, kad robotas gali pasiekti plačiausią greičių diapazoną šia eisena.

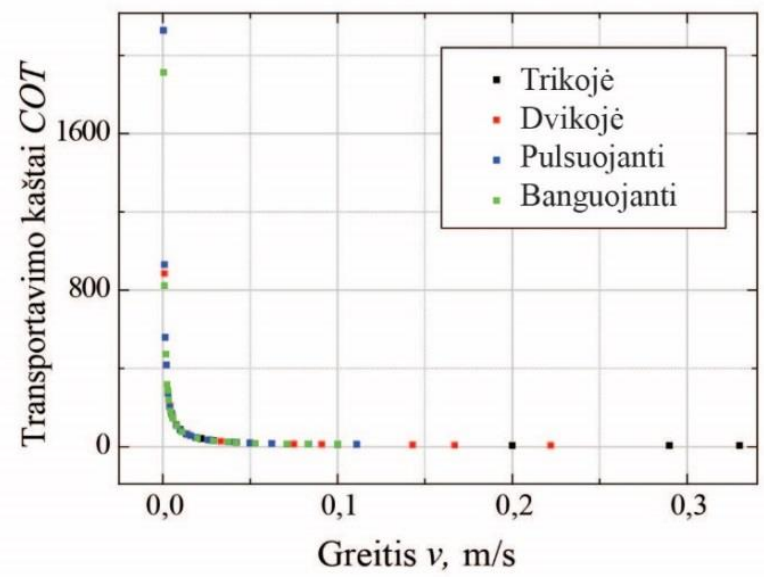

3.9 pav. Šešiakojo roboto transportavimo kaštų priklausomybė nuo greičio

Fig. 3.9. Hexapod robot cost of transport dependence on speed

Gauti transportavimo kaštų rezultatai buvo palyginti su kitų vaikščiojančių robotų transportavimo kaštais. Palyginimas pateiktas 3.2 lenteleje. Nors visų mikro robotų masė yra labai maža $(0,002-0,3 \mathrm{~kg})$, tačiau transportavimo kaštų vertès yra didelès $(\sim 9-130)$, o tai rodo šių robotų dideli trūkumą. Didesnių robotų, tokių kaip „RHex“, „Gregor I“ ir „AMOS“, masès yra didesnès ir transportavimo kaštų vertès yra palyginti žemos. Tyrimuose naudojamo šešiakojo roboto HexaV4 transportavimo kaštų vertẻ išlieka mažiausia, nepriklausomai nuo roboto masès. Lyginant su kitais panašios masès robotais, HexaV4 yra vienas iš energetiškai efektyviausių vaikščiojančių robotų. 
3.2 lentelè. Skirtingų vaikščiojančių robotų masės ir transportavimo kaštų vertès (A. T. Baisch et. al. 2010, P. Arena et. al. 2006, X. Xiong et. al. 2015)

Table 3.2. Mass and cost of transport values of different walking robots (A. T. Baisch et. al. 2010, P. Arena et. al. 2006, X. Xiong et. al. 2015)

\begin{tabular}{|c|c|c|}
\hline Robotas & Masè, kg & COT \\
\hline „Mini-Whegs“ & 0,146 & 8,9 \\
\hline „DASH“ & 0,0162 & 14,7 \\
\hline „iSprawl“ & 0,3 & 17,4 \\
\hline „HAMR2“ & 0,002 & 128 \\
\hline „RHex“ & 7,5 & 20 \\
\hline Gregor I & 1,2 & 70 \\
\hline AMOS & 5,4 & 11,7 \\
\hline HexaV4 & 1,5 & 5,75 \\
\hline
\end{tabular}

Siekiant minimizuoti šešiakojo roboto energijos sąnaudas buvo sukurtas specialus algoritmas (3.10 pav.). Šis algoritmas yra programa, valdoma aukšto lygio komandomis. Programos tikslas - parinkti tinkamą eiseną priklausomai nuo roboto judējimo greičio. Algoritmas sudarytas roboto judejjimui be papildomos apkrovos.

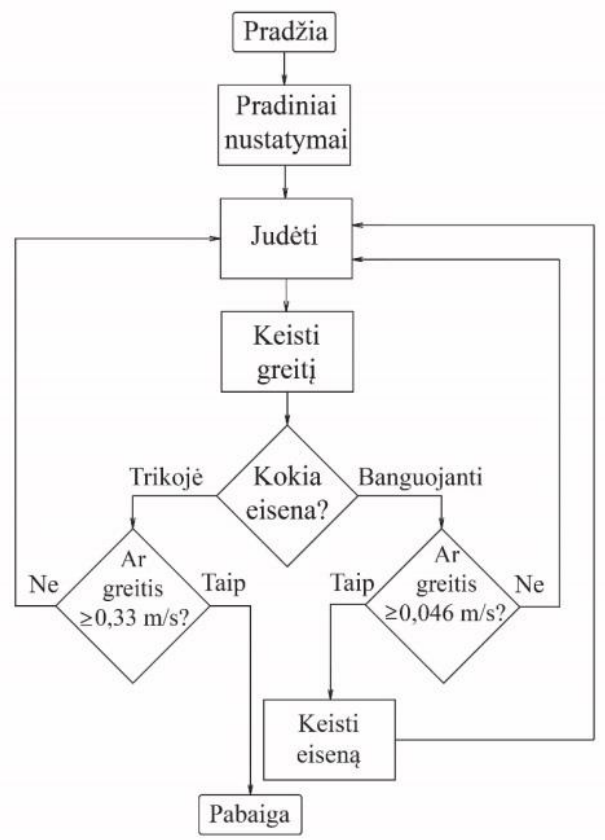

3.10 pav. Eisenos keitimo algoritmas

Fig. 3.10. Gait switching algorithm 
Algoritmo pradžioje yra nustatomi pradiniai parametrai: pradinis greitis, banguojanti eisena, žingsnio trajektorijos aukštis $0,01 \mathrm{~m}$. Tada robotas juda $\mathfrak{i}$ priekị tol, kol atliekami pilni 4 judejjimo ciklai ir didinamas greitis keičiant arba žingsnio trajektorijos ilgi, arba servo pavaru greiti; greičio keitimas yra iprogramuotas i roboto valdymo programą. Toliau tikrinama, kokia eisena yra parinkta. Jeigu robotas juda mažu greičiu banguojančia eisena, tikrinama, ar greitis yra mažesnis arba lygus $0,046 \mathrm{~m} / \mathrm{s}$. Tokiu atveju tęsiamas judejimas ir greičio didinimas. Jeigu robotas juda banguojančia eisena ir yra pasiektas $0,046 \mathrm{~m} / \mathrm{s}$ greitis, inicijuojamas eisenos keitimas ir pereinama ị trikoję eiseną. Eisenos pakeitimas reikalingas, siekiant išlaikyti minimalu suvartojamos energijos kieki. Toliau roboto greitis didinamas iki tol, kol pasiekiamas $0,33 \mathrm{~m} / \mathrm{s}$ greitis. Tai yra maksimalus galimas HexaV4 roboto greitis, todèl pasiekus ji, programa stabdoma.

Eisenos keitimo algoritmas buvo įrašytas i šešiakojo roboto valdymo programą ir patikrintas keletą kartų su ir be papildomo vèlinimo tarp greičio keitimų. Vèlinimo laikas taip pat buvo keičiamas, norint gauti geresnius rezultatus vidutinio elektros srovés stiprio skaičiavimams. Vieno nuoseklaus matavimo elektros srovès stiprio rezultatai be papildomo vèlinimo pateikti 3.11 paveiksle. Aukštas triukšmų lygis buvo mažinamas naudojamas procentinị filtrą $(50 \%)$.

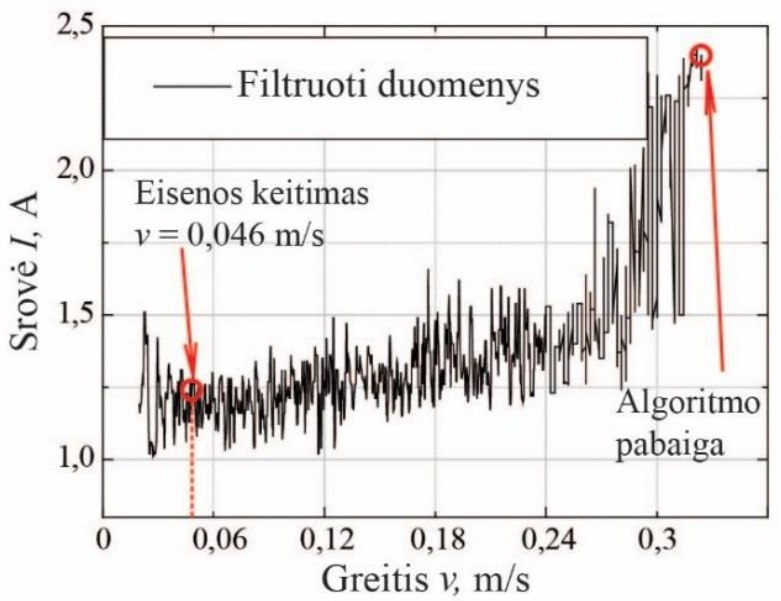

3.11 pav. Šešiakojo roboto pavarų elektros srovès stiprio priklausomybè nuo greičio, gauta keičiant roboto judejimo greiti ir eiseną

Fig. 3.11. Hexapod robot current consumption dependence on speed, achieved by varying robots movement speed and gait 


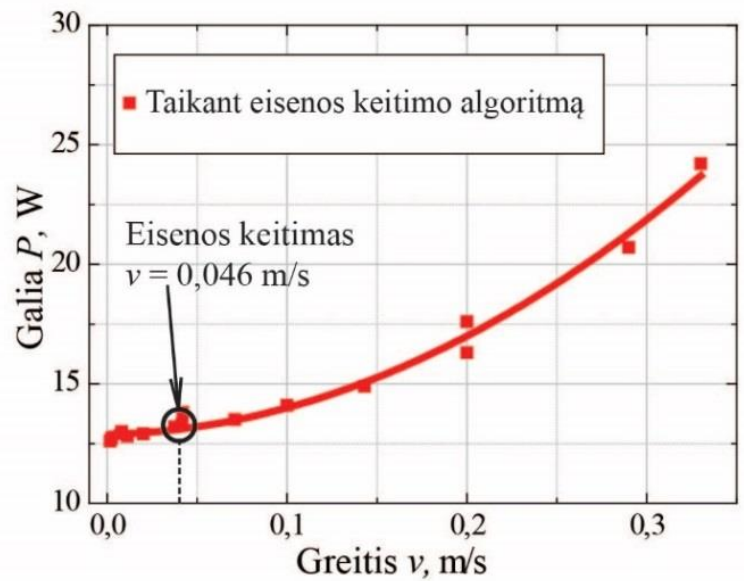

3.12 pav. Roboto vartojamos vidutinès galios priklausomybės nuo judejjimo greičio taikant eisenos keitimo algoritmą

Fig. 3.12. Robots average power consumption dependence on speed using gait switching algorithm

Naudojantis gautais rezultatais buvo skaičiuojamos vidutinès elektros srovès stiprio vertès kiekvienam intervalui. Tokiu būdu buvo gautos roboto vartojamos galios vertès. Kaip matyti iš 3.12 paveikslo, kitimo dèsnis išlieka tas pats ir vertès paklaidų ribose yra tokios pačios kaip 3.4 paveiksle. Toks rezultatas įrodo, kad naudojant sukurtą eisenos keitimo algoritmą, galima išlaikyti suvartojamos energijos minimumą. Todèl galima teigti, kad šis algoritmas yra tinkamas vaikščiojančių šešiakojų robotų energijos sąnaudų minimizavimui judant lygiu paviršiumi, nes visiems šešiakojams taikomos tokios pačios eisenos.

\subsection{Roboto judèjimo per kliūtis tyrimas}

Čia pateikiami roboto judejimo per kliūtis tyrimo rezultatai. Tyrimo tikslas ištirti vaikščiojančio roboto gebejjimą įveikti įvairaus dydžio ir tankio kliūtis ivvertinant nuokrypius nuo numatytos judejjimo trajektorijos. Eksperimentai atlikti taikant kliūčių aptikimo ir perlipimo metodą, kuris plačiau aprašytas 2.2 poskyryje.

Visų pirma buvo atlikti kalibravimo tyrimai ir roboto judejimo įvertinimas netaikant minèto metodo. Neturint tokios informacijos būtų sunku vertinti santykinius nuokrypius nuo numatytos trajektorijos bei neįmanoma pateikti palyginimo tarp roboto judèjimo parametrų siekiant nustatyti pasiūlyto metodo veiksmingumą.

Visuose sekančiuose eksperimentuose buvo naudojamos dvi pagrindinès šešiakojų robotų eisenos su joms būdingais greičiais: banguojanti eisena, kurios 
greitis buvo nustatytas $0,013 \mathrm{~m} / \mathrm{s}$ bei trikojè eisena, kurios greitis $-0,036 \mathrm{~m} / \mathrm{s}$. Kiekvienas paviršius buvo išskaidytas $\mathfrak{i}$ du atstumus: $1 \mathrm{~m}$ ir $2 \mathrm{~m}$. Tada buvo atlikti tyrimai siekiant nustatyti kiekvienai eisenai reikalingą judejjimo ciklų skaičių, norint nukeliauti numatytus atstumus. Roboto judejimui banguojančia eisena reikalingi 20 ciklų, kad nukeliautų $1 \mathrm{~m}$ atstumą ir 40 ciklų, kad nukeliautų $2 \mathrm{~m}$ atstumą. Roboto judejjimui trikoje eisena reikalingi 13 ciklų nukeliauti $1 \mathrm{~m}$ atstumą ir 26 ciklai nukeliauti $2 \mathrm{~m}$ atstumą.

Kalibravimo tyrimai buvo sudaryti iš eksperimentų, kai robotas juda lygiu paviršiumi be kliūčių roboto kelyje, ir eksperimentų, kai robotas juda paviršiumi su kliūtimis, tačiau netaikant pasiūlyto kliūčiu perlipimo metodo. Eksperimentų be kliūčių metu buvo matuojami $x$ ir $y$ koordinačių nuokrypiai galiniame taške siekiant ịvertinti, kaip gerai robotas pasiekia jam numatytą tikslą. Rezultatai pateikti 3.3 lentelèje. Kalibravimo eksperimentų metu su kliūtimis be kliūčių perlipimo metodo buvo naudojamas tik mažo kliūčių tankio paviršius ir numatytas atstumas buvo $1 \mathrm{~m}$. Papildomai galiniame taške buvo matuojamas roboto nukrypimo kampas. Matavimų paaiškinimas pateiktas 3.13 paveiksle. Judèjimo rezultatai be kliūčių perlipimo metodo pateikti 3.14 paveiksle.

3.3 lentelė. Nuokrypiai nuo numatytos trajektorijos judant paviršiumi be kliūčių

Table 3.3. Straight path deviations from given trajectory during locomotion over terrain without obstacles

\begin{tabular}{|c|c|c|c|}
\hline \multicolumn{2}{|c|}{ Banguojanti eisena } & \multicolumn{2}{c|}{ Trikojė eisena } \\
\hline$d=1 \mathrm{~m}$ & $d=2 \mathrm{~m}$ & $d=1 \mathrm{~m}$ & $d=2 \mathrm{~m}$ \\
\hline \multicolumn{4}{|c|}{$(x, y) \mathrm{m}$} \\
\hline$(0,02 ;-0,01)$ & $(0,03 ;-0,04)$ & $(0,01 ;-0,02)$ & $(-0,04 ;-0,05)$ \\
\hline$(0,02 ;-0,01)$ & $(0,02 ;-0,05)$ & $(0,01 ;-0,01)$ & $(-0,03 ;-0,06)$ \\
\hline$(0,02 ;-0,01)$ & $(0,02 ;-0,06)$ & $(0,01 ;-0,02)$ & $(-0,03 ;-0,05)$ \\
\hline \multicolumn{4}{|c|}{ Vidutinès vertès } \\
\hline$(0,02 ; 0,01)$ & $(0,02 ; 0,05)$ & $(0,01 ; 0,02)$ & $(0,03 ; 0,05)$ \\
\hline
\end{tabular}

Mažiausi nuokrypiai nuo tiesaus judejjimo gaunami judant trumpesni atstumą trikoje eisena $(0,01-0,02 \mathrm{~m})$, tačiau judant $2 \mathrm{~m}$ atstumą gaunami didžiausi nuokrypiai $(0,03-0,05 \mathrm{~m})$ (3.3 lentelè). Robotui judant banguojančia eisena nuokrypiai išlieka daugmaž vienodi nepriklausomai nuo kelio ilgio $(0,01-$ $0,05 \mathrm{~m})$. Žinant, kad idealus judejjimas būtų $0 \mathrm{~m}$ nuokrypiai, galima teigti, kad gauti nuokrypiai judant per paviršių be kliūčių yra maži, atsirandantys daugiausiai dèl mechaninių netikslumų. 


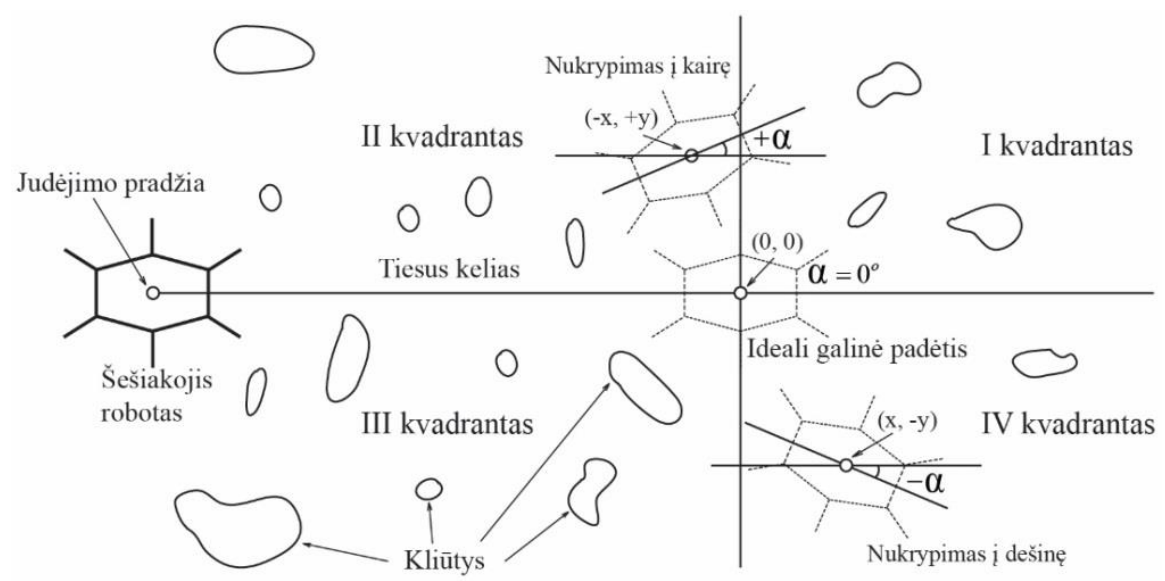

3.13 pav. Nuokrypių nuo numatytos trajektorijos ir judejjimo krypties kampo matavimai. I kvadrantas: $(+x,+y)$ ir $+\alpha$; II kvadrantas: $(-x,+y)$ ir $+\alpha$; III kvadrantas: $(-x,-y)$ ir $-\alpha$; IV kvadrantas: $(+x,-y)$ ir $-\alpha$

Fig. 3.13. Measuring straight path deviations and direction angle change. I quadrant: $(+x,+y)$ and $+\alpha$; II quadrant: $(-x,+y)$ and $+\alpha$; III quadrant: $(-x,-y)$ and $-\alpha ;$ IV quadrant: $(+x,-y)$ and $-\alpha$
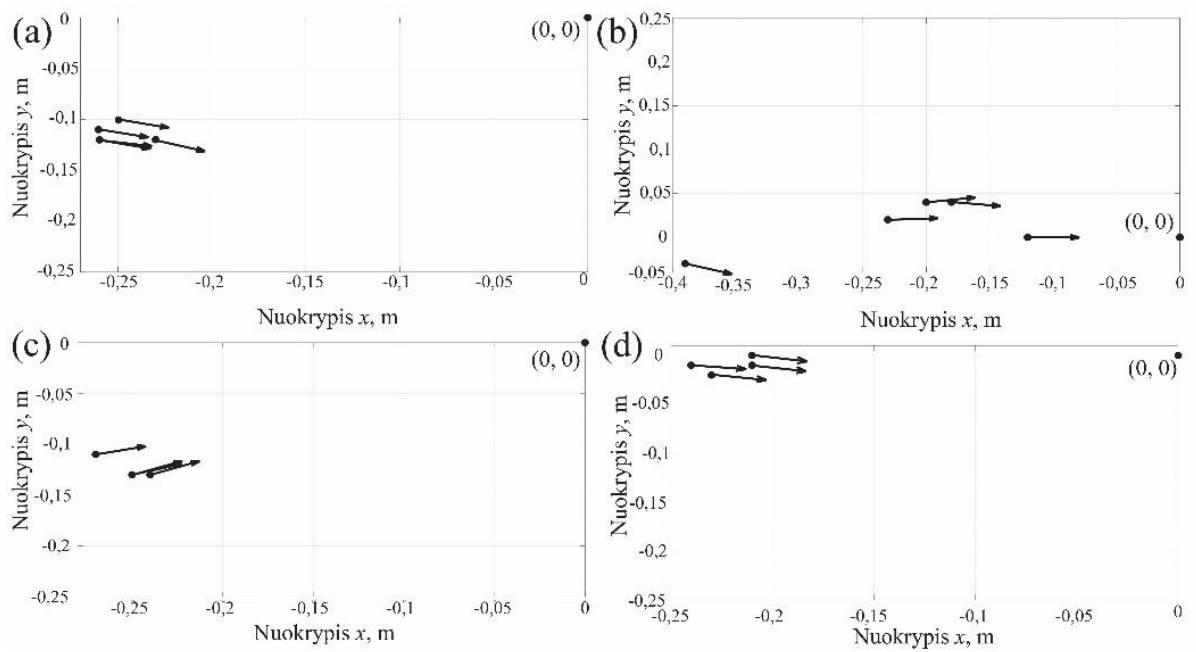

3.14 pav. Nuokrypiai nuo numatytos trajektorijos be kliūčių perlipimo metodo esant mažam kliūčių tankiui: (a) banguojanti eisena, mažas kliūčių aukštis, $1 \mathrm{~m}$ atstumas; (b)

banguojanti eisena, didelis kliūčių aukštis, $1 \mathrm{~m}$ atstumas; (c) trikojè eisena, mažas kliūčių aukštis, $1 \mathrm{~m}$ atstumas; (d) trikojè eisena, didelis kliūčių aukštis, $1 \mathrm{~m}$ atstumas Fig. 3.14. Deviations from given trajectory without obstacle avoidance method during locomotion over low density terrain: (a) wave gait, small height obstacles, $1 \mathrm{~m}$ distance; (b) wave gait, large height obstacles, $1 \mathrm{~m}$ distance; (c) tripod gait, small height obstacles, $1 \mathrm{~m}$ distance; (d) tripod gait, large height obstacles, $1 \mathrm{~m}$ distance 
3.14 paveikslo mastelis pasirinktas taip, kad būtų matomos galinio taško koordinatès. Kitaip nèra ịmanoma ịvertinti atstumo tarp roboto galinès padèties ir numatyto galinio taško koordinačių. Toks mastelis buvo naudojamas ir pateikiant rezultatus tolimesniuose paveiksluose.

3.15 ir 3.16 paveiksluose vaizduojami judejjimo nuokrypiai nuo numatytos trajektorijos rezultatai trikojei ir banguojančiai eisenai atskirai. Siekiant tiksliai ịvertinti kliūčiu perlipimo metodo veiksmingumą buvo atlikti 144 eksperimentai su 2 skirtingais kliūčiu tankiais, 2 skirtingais atstumais ir 2 skirtingais kliūčių aukščiu intervalais. Šešiakojo roboto HexaV4 judejjimo pavyzdys judant banguojančia eisena per didelio tankio paviršių pavaizduotas 3.17 paveiksle. Paveiksle matyti, kaip robotas judejjimo pradžioje laikosi numatytos judejjimo trajektorijos (3.17 pav. (a)), o judèjimo gale roboto padètis nukrypsta nuo norimo rezultato (3.17 pav. (b)).
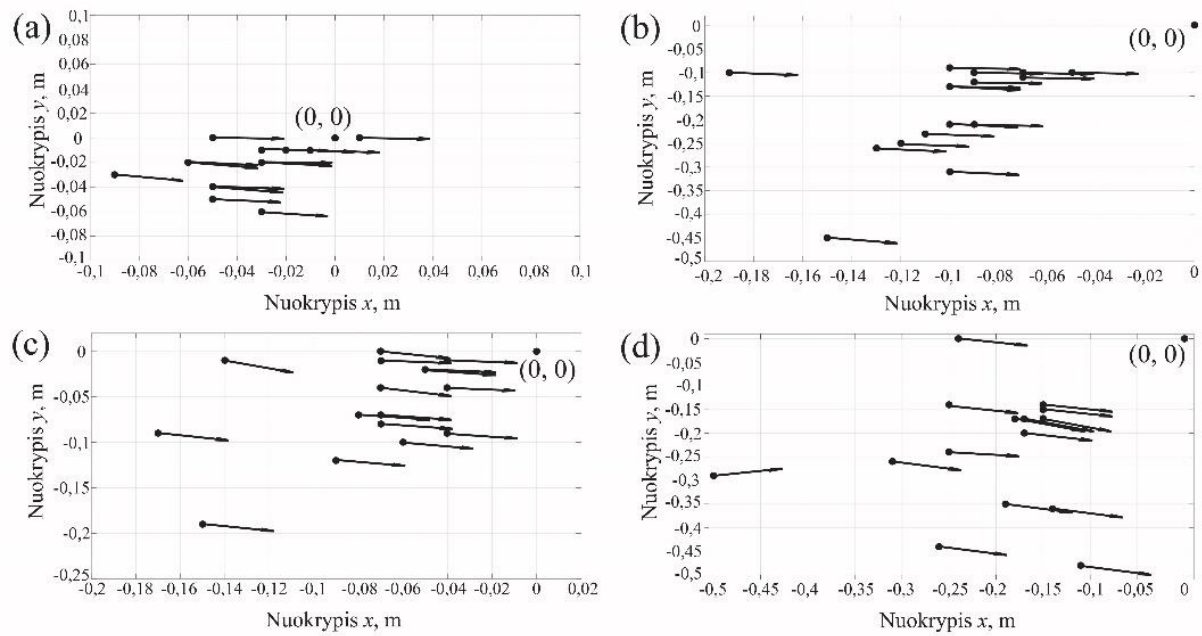

3.15 pav. Roboto judejjimo per kliūtis taikant banguojančią eiseną eksperimentų rezultatai: (a) mažas kliūčių tankis, $1 \mathrm{~m}$ atstumas; (b) mažas kliūčių tankis, $2 \mathrm{~m}$ atstumas; (c) didelis kliūčių tankis, $1 \mathrm{~m}$ atstumas; (d) didelis kliūčių tankis, $2 \mathrm{~m}$ atstumas Fig. 3.15. Results of robot locomotion over obstacles using wave gait: (a) low obstacle density, $1 \mathrm{~m}$ distance; (b) low obstacle density, $2 \mathrm{~m}$ distance; (c) high obstacle density, $1 \mathrm{~m}$ distance; (d) high obstacle density, $2 \mathrm{~m}$ distance

Robotas negali judèti per paviršiu su kliūtimis be kliūčiu perlipimo metodo, nes roboto kojos atsitrenkia ị kliūtis ir robotas stumiasi atgal visą likusị laiką. Tai taip pat paaiškina, kodèl $x$ koordinatès nuokrypiai yra didesni nei $y$ koordinatès. Judejjimo metu netaikant kliūčiu perlipimo metodo vidutiniai nuokrypiai buvo suskaičiuoti iš 3.14 paveiksle pateiktų duomenų. Banguojančiai eisenai nuokrypiai yra šie: $(0,252 ; 0,114) \mathrm{m} 17,4^{\circ}$ esant mažo aukščio kliūtims ir 
$(0,224 ; 0,026) \mathrm{m} 6,8^{\circ}$ esant didelio aukščio kliūtims. Vidutiniai nuokrypiai trikojei eisenai: $(0,252 ; 0,126) \mathrm{m} 22,8^{\circ}$ esant mažo aukščio kliūtims ir $(0,22$; $0,008) \mathrm{m} 12^{\circ}$ esant didelio aukščio kliūtims. Visos vidutinès nuokrypių vertès apskaičiuotos naudojant absoliutines vertes. Iš gautų rezultatų matyti, kad robotas negali pasiekti galinio taško net $1 \mathrm{~m}$ atstumu netaikant kliūčiu perlipimo metodo, nes vidutiniai nuokrypiai siekia $\sim 24 \%$.

(a)
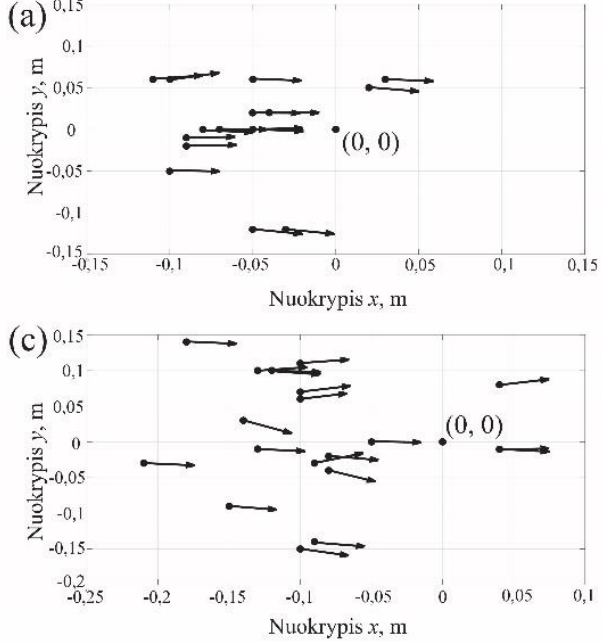

(b)

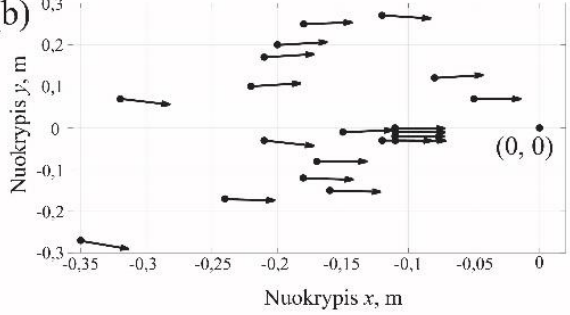

(d)

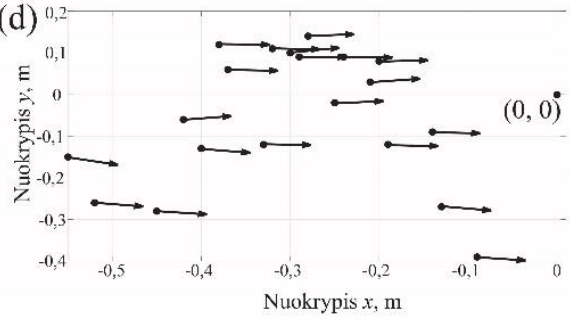

3.16 pav. Roboto judèjimo per kliūtis taikant trikoję eiseną eksperimentų rezultatai: (a) mažas kliūčių tankis, $1 \mathrm{~m}$ atstumas; (b) mažas kliūčių tankis, $2 \mathrm{~m}$ atstumas; (c) didelis kliūčių tankis, $1 \mathrm{~m}$ atstumas; (d) didelis kliūčių tankis, $2 \mathrm{~m}$ atstumas

Fig. 3.16. Results of robot locomotion over obstacles using tripod gait: (a) low obstacle density, $1 \mathrm{~m}$ distance; (b) low obstacle density, $2 \mathrm{~m}$ distance; (c) high obstacle density, $1 \mathrm{~m}$ distance; (d) high obstacle density, $2 \mathrm{~m}$ distance

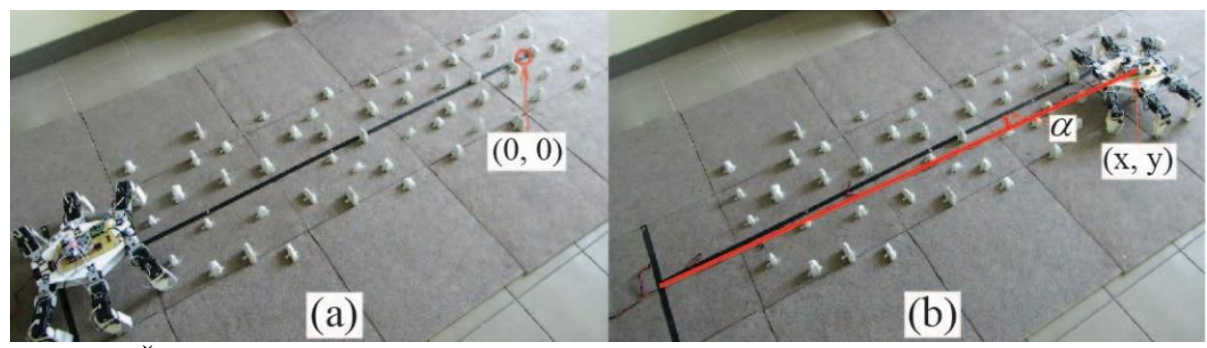

3.17 pav. Šešiakojo roboto judèjimas banguojančia eisena per didelio tankio paviršių su mažo aukščio kliūtimis: (a) roboto padètis pradiniame taške; (b) roboto padètis galiniame taške

Fig. 3.17. Hexapod robot locomotion over high density terrain with small height obstacles using wave gait: (a) robot position at starting point; (b) robot position at goal position 
Vidutinès nuokrypių vertės buvo skaičiuojamos atskirai, priklausomai nuo nueito kelio, nes tuo būdu buvo galima ịvertinti, kaip stipriai robotas nukrypsta nuo numatytos trajektorijos didejant atstumui (nuo $1 \mathrm{~m}$ iki $2 \mathrm{~m}$ ). Gautos vertès pateiktos 3.4 lentelèje.

Šie rezultatai patvirtina, kad naudojant banguojančią eiseną galima pasiekti patenkinamus rezultatus judejjimui per bet kokio tipo paviršių. Netgi nepaisant to, kad kuo didesni atstumą robotui reikia nueiti ir kuo didesnès kliūtys, tuo didesni nuokrypiai, robotas vis tiek sugeba perlipti visas kelyje pasitaikančias kliūtis ir priartèti prie galinio taško. Naudojant trikoję eiseną judèjimas per kliūtis yra taip pat ịmanomas, tačiau nuokrypiai yra daugiau atsitiktiniai dèl skirtingo kojų perkèlimo eiliškumo ir didesnio judèjimo greičio. Trikojẻs eisenos eksperimentų metu kliūtys dažniau užstrigdavo tarp roboto kojos ir kliūčių aptikimo jutiklio. Netgi tokiu atveju roboto koja nuslysdavo nuo kliūties ir robotas tęsdavo judejimą i priekị. Tokie užstrigimai nulemdavo didesnius $x$ koordinatès nuokrypius, tačiau rezultatai vis tiek yra $50 \%$ geresni nei netaikant kliūčių perlipimo metodo.

3.4 lentelè. Vidutinès nuokrypių nuo numatytos trajektorijos vertès robotui judant skirtingus atstumus

Table 3.4. Average deviations from given trajectory while robot is moving different distances

\begin{tabular}{|c|c|c|c|}
\hline \multicolumn{2}{|c|}{ Banguojanti eisena } & \multicolumn{2}{c|}{ Trikojè eisena } \\
\hline$d=1 \mathrm{~m}$ & $d=2 \mathrm{~m}$ & $d=1 \mathrm{~m}$ & $d=2 \mathrm{~m}$ \\
\hline \multicolumn{3}{|c|}{$(x, y) \mathrm{m}, \alpha^{\mathrm{o}}$} \\
\hline$(0,057 ; 0,042), 7^{\circ}$ & $(0,161 ; 0,206), 11,7^{\circ}$ & $(0,083 ; 0,052), 7,3^{\circ}$ & $(0,237 ; 0,127), 6,6^{\circ}$ \\
\hline
\end{tabular}

Taip pat reikètų atkreipti dèmesị ir ị tai, kad nuokrypius ịtakoja ir kliūčių pozicijos todèl, kad kliūtys buvo išdèstomos atsitiktinai, o ne simetriškai (realios aplinkos imitavimas). Kai kuriais atvejais roboto nuokrypiai $y$ koordinatès ašimi būdavo atstatomi dèl to, kad roboto kojos atsitrenkdavo ị skirtingas kliūtis, tarp kurių būdavo atstumas. Nors atstumas tarp kliūčių darbo metu nebuvo matuojamas, tai nulemdavo, kiek bus atstatomi nukrypimai $y$ koordinatės ašimi.

Lyginant nuokrypių dydị su darbe naudojamo šešiakojo roboto dydžiu, nei vienu atveju nebuvo gauti nuokrypiai, didesni nei roboto ilgis, kuris yra $0,25 \mathrm{~m}$. Santykinai visi nuokrypiai yra mažesni nei $\sim 12 \%$. Toks rezultatas yra dvigubai mažesnis nei be kliūčių perlipimo metodo. Lyginant atskirų eisenų rezultatus galima teigti, kad nors taikant lètesnes eisenas galima gauti mažesnius nuokrypius bet kokiomis sąlygomis, greitesnès eisenos gali būti naudojamos roboto judejimui trumpesniais atstumais. 


\subsection{Energijos sąnaudų minimizavimo judant per kliūtis tyrimas}

Šiame poskyryje pateikiami tyrimai, kurie buvo atlikti $M A T L A B^{\circledast}$ matematinio modeliavimo aplinkoje. Tyrimo tikslas: ištirti kliūčių perlipimo efektyvumą robotui judant per skirtingo dydžio kliūtis lyginant gautus energijos sąnaudų rezultatus. Tyrimai susiję su energijos sąnaudų minimizavimu parenkant parametrus dviem atvejais: kai roboto koju judesiai yra sinchronizuoti laiko atžvilgiu ir kai kojų judesiai nèra sinchronizuoti laiko atžvilgiu.

Norint tinkamai ịvertinti energijos sąnaudas atliekant imitacinius tyrimus, buvo atlikti papildomi matavimai su realiu šešiakoju robotu siekiant nustatyti vidutinio elektros srovès stiprio priklausomybę nuo roboto žingsnio trajektorijos aukščio ir pločio. Pėdos trajektorijos generavimas taikant (2.45) lygti buvo integruotas i roboto valdymo sistemą ir pavaru elektros srovès stipris buvo stebimas naudojant elektros srovès stiprio matavimo schemą. Oscilografu buvo matuojamas priekinès kairès roboto kojos pavarų srovės stipris. (3.18 pav.).

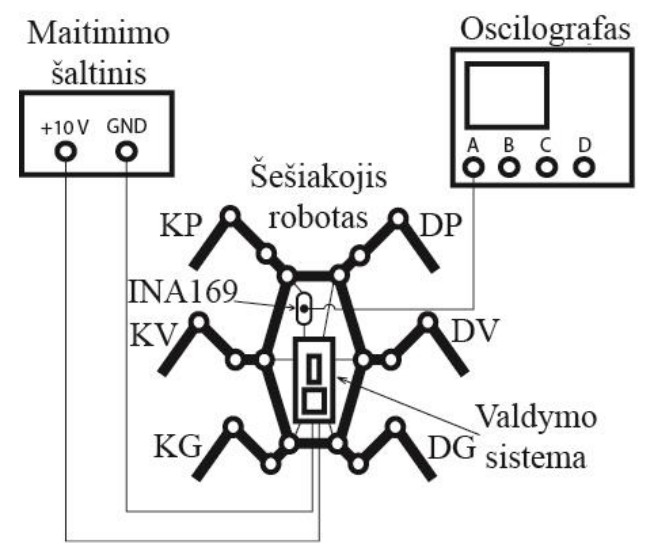

3.18 pav. Elektros srovès stiprio matavimo funkcinè schema. Elektros srovès stiprio matavimo schema prijungta tarp roboto KP kojos pavarų ir ịtampos šaltinio

Fig. 3.18. Current consumption measuring function diagram. Current measuring circuit installed on robots LF leg between power supply and servo drives

Visų šiu imitacinių tyrimų metu buvo naudojama trikojè eisena, o roboto judèjimo greitis $v=0,025 \mathrm{~m} / \mathrm{s}$. Kiekviena kojos konfigūracija (žingsnio trajektorijos aukščio ir pločio) buvo matuojama vieną kartą ir vidutinė roboto kojos pavarų elektros srovés stiprio verte gaunama taikant (3.2) lygti. Vieno matavimo užtenka todèl, kad rezultate buvo gaunama 5000 elektros srovès stiprio matavimo verčių. Galima teigti, kad tai yra pakankamas kiekis duomenų tinkamai įvertinti vidutinę vertę. Vieno matavimo trukmė buvo $5 \mathrm{~s}$. Taigi 
elektros srovès stiprio matavimo intervalas lygus $1 \mathrm{~ms}$. Elektros srovès stiprio priklausomybès nuo žingsnio trajektorijos parametrų rezultatai pateikti 3.5 lentelèje.

3.5 lentelès duomenys buvo perdaryti i dvimatę matricą ir integruoti $\mathfrak{i}$ imitacini modelį. Matricos stulpeliai vaizduoja žingsnio trajektorijos plotị, o matricos eilutès - žingsnio trajektorijos aukštị.

3.5 lentelė. Elektros srovès stiprio priklausomybè nuo roboto žingsnio trajektorijos aukščio ir pločio

Table 3.5. Current consumption dependence on robot step trajectory height and width

\begin{tabular}{|c|c|c|c|c|c|c|c|c|c|c|}
\hline \multirow{3}{*}{$w, \mathrm{~cm}$} & \multicolumn{10}{|c|}{$h, \mathrm{~cm}$} \\
\cline { 2 - 13 } & 1 & 2 & 3 & 4 & 5 & 6 & 7 & 8 & 9 & 10 \\
\cline { 2 - 12 } & \multicolumn{10}{|c|}{$I_{\text {vid }}, \mathrm{mA}$} \\
\hline 0 & 194 & 202 & 205 & 208 & 208 & 207 & 219 & 219 & 218 & 224 \\
\hline 1 & 197 & 203 & 204 & 209 & 207 & 215 & 214 & 216 & 221 & 222 \\
\hline 2 & 258 & 202 & 205 & 206 & 210 & 208 & 211 & 217 & 219 & 219 \\
\hline 3 & 256 & 245 & 198 & 203 & 206 & 205 & 213 & 212 & 212 & 214 \\
\hline 4 & 215 & 244 & 236 & 205 & 208 & 204 & 206 & 208 & 211 & 213 \\
\hline 5 & 252 & 248 & 230 & 215 & 201 & 207 & 209 & 209 & 209 & 211 \\
\hline 6 & 252 & 254 & 247 & 234 & 223 & 208 & 203 & 209 & 208 & 208 \\
\hline
\end{tabular}

Imitacinis roboto modelis buvo papildytas roboto judèjimu lygiu paviršiumi ir su kliūtimis, kad atliekami tyrimai būtų kuo realistiškesni. Energijos sąnaudų minimizavimo imitaciniai tyrimai atlikti naudojant tris skirtingų kliūčių tankių paviršius. Buvo naudojami mažo tankio (10 kliūčių per visą duotą atstumą), vidutinio tankio (20 kliūčių) ir didelio tankio (30 kliūčių) paviršiai (3.19 pav.). Visos kliūtys modelyje buvo nusakomos šiais parametrais: ilgiu, pločiu, aukščiu bei $x$ ir $y$ koordinatemis, kurios nusakẻ kiekvienos kliūties padètị aplinkoje bei buvo naudojamos imituoti roboto kliūčių aptikimui. Be šiu parametrų robotas judètų kaip lygiu paviršiumi ir nežinotų, kada keisti kojos trajektoriją. Taip pat, kiekvienos kojos judejjimo greitis buvo nustatytas toks pats, kaip roboto judejjimo greitis, tokiu būdu užtikrinant, kad kojų judesiai nėra sinchronizuoti laiko atžvilgiu. Pradiniai judejjimo parametrai buvo tokie: žingsnio ilgis $l=0,04 \mathrm{~m}$, aukštis $h=0,01 \mathrm{~m}$. Visų tyrimų metu robotas turejo nueiti $3,2 \mathrm{~m}$ atstumą ir perlipti visas kliūtis. Kliūčių dydžiai buvo parenkami atsitiktinai, todèl kiekvieno matavimo metu kliūčių dydžiai buvo labai įvairūs. Taip daryti pasirinkta siekiant imituoti realų paviršių. Tikrovèje paviršius retai yra apibrežtas ir kliūčių dydžiai dažniausiai yra skirtingi. Vidutinių suvartojamos energijos verčiu rezultatai pateikti 3.5-3.7 lentelèse. Apibendrinti energijos sąnaudų rezultatai pateikti 3.8 lentelèje. Visos suvartojamos energijos sąnaudų vertès buvo skaičiuojamos taikant atitinkamas lygtis aprašytas 2.3.3 poskyryje. 


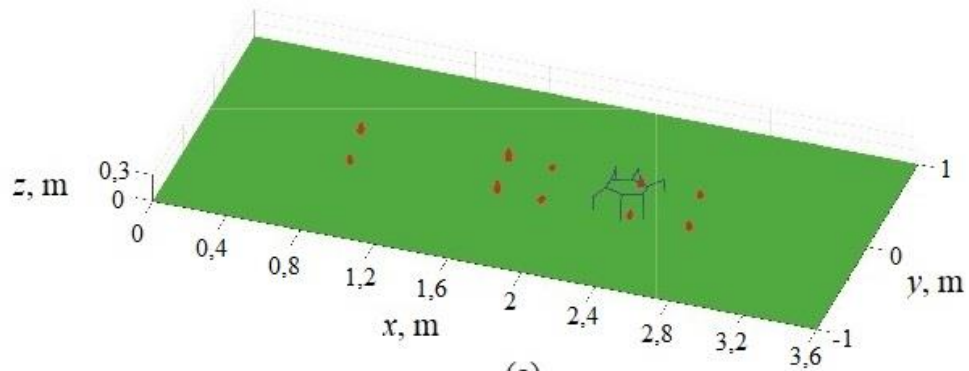

(a)

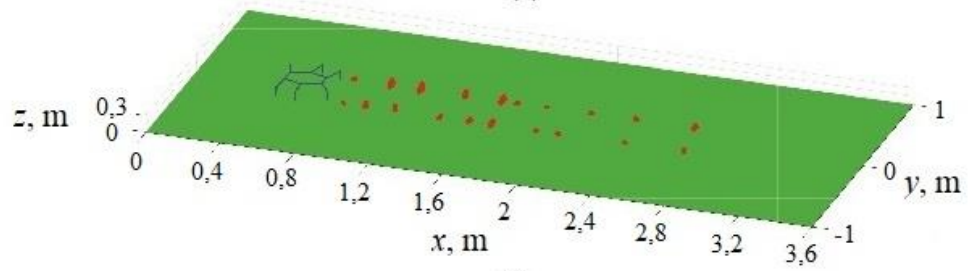

(b)

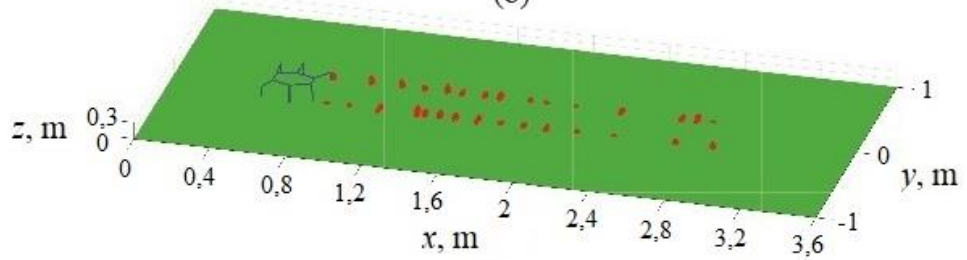

(c)

3.19 pav. Šešiakojo roboto žingsniavimo per skirtingų tankių paviršius modeliavimo pavyzdžiai: (a) mažas tankis; (b) vidutinis tankis; (c) didelis tankis

Fig. 3.19. Simulation examples of hexapod robot locomotion over different obstacle density terrains: (a) low density; (b) average density; (c) high density

3.6-3.9 lentelèse $E$ vaizduoja energijos sąnaudas be parametrų parinkimo, $E_{\text {opt }}$ vaizduoja energijos sąnaudas parenkant tinkamiausius parametrus pagal pėdos trajektorijos ilgị bei tenkančios elektros srovès stiprį, energijos sąnaudų skirtumą tarp su ir be parametrų parinkimo vaizduoja $E-E_{o p t}$, o $\eta$ vaizduoja metodo efektyvumą (sutaupytą energijos kieki). Kuo didesnè $\eta$ vertè, tuo mažesnis energijos kiekis yra suvartojamas.

Nors 3.6-3.9 lentelèse galima ịžvelgti nedidelị energijos sąnaudų augimą priklausomai nuo kliūčių skaičiaus roboto kelyje, vidutinis metodo efektyvumas kinta nežymiai (iki 7-11\%). Toks efektyvumo kitimas priklausė nuo kliūčių dydžių aplinkoje, kurie buvo parenkami atsitiktinai. Iš 3.9 lentelès matyti, kad vidutinis kliūčiu perlipimo su parametrų parinkimu metodu efektyvumas yra $14,9 \%$. Nors tai nèra didelis skirtumas, tačiau net mažas energijos kiekis gali turèti didelę ịtaką roboto darbo laikui. 
3.6 lentelè. HexaV4 šešiakojo roboto energijos sąnaudos judant mažo kliūčių tankio paviršiumi

Table 3.6. Energy consumption of HexaV4 hexapod robot locomotion over low complexity terrain

\begin{tabular}{|c|c|c|c|c|}
\hline \multicolumn{5}{|c|}{ Mažo tankio paviršius (10 kliūčių) } \\
\hline Matavimas & $E, \mathbf{J}$ & $E_{\text {opt }}, \mathrm{J}$ & $E-E_{\text {opt }}, \mathrm{J}$ & $\eta, \%$ \\
\hline 1 & 1520 & 1347 & 173 & 11,4 \\
\hline 2 & 1585 & 1320 & 265 & 16,7 \\
\hline 3 & 1531 & 1367 & 164 & 10,7 \\
\hline 4 & 1496 & 1381 & 115 & 7,7 \\
\hline 5 & 1625 & 1327 & 298 & 18,3 \\
\hline
\end{tabular}

3.7 lentelè. HexaV4 šešiakojo roboto energijos sąnaudos judant vidutinio kliūčių tankio paviršiumi

Table 3.7. Energy consumption of HexaV4 hexapod robot locomotion over average complexity terrain

\begin{tabular}{|c|c|c|c|c|}
\hline \multicolumn{5}{|c|}{ Mažo tankio paviršius (20 kliūčių) } \\
\hline Matavimas & $E, \mathbf{J}$ & $E_{\mathrm{opt}}, \mathrm{J}$ & $E-E_{\mathrm{opt}}, \mathrm{J}$ & $\eta, \%$ \\
\hline 1 & 1806 & 1548 & 258 & 14,3 \\
\hline 2 & 1735 & 1502 & 233 & 13,4 \\
\hline 3 & 1761 & 1493 & 268 & 15,2 \\
\hline 4 & 1852 & 1477 & 375 & 20,2 \\
\hline 5 & 1832 & 1516 & 316 & 17,2 \\
\hline
\end{tabular}

3.8 lentelè. HexaV4 šešiakojo roboto energijos sąnaudos judant didelio kliūčių tankio paviršiumi

Table 3.8. Energy consumption of HexaV4 hexapod robot locomotion over high complexity terrain

\begin{tabular}{|c|c|c|c|c|}
\hline \multicolumn{5}{|c|}{ Mažo tankio paviršius (30 kliūčių) } \\
\hline Matavimas & $E, \mathrm{~J}$ & $E_{\mathrm{opt}}, \mathrm{J}$ & $E-E_{\mathrm{opt}}, \mathrm{J}$ & $\eta, \%$ \\
\hline 1 & 1852 & 1585 & 267 & 14,4 \\
\hline 2 & 1839 & 1586 & 253 & 13,8 \\
\hline 3 & 1722 & 1529 & 193 & 11,2 \\
\hline 4 & 1933 & 1610 & 323 & 16,7 \\
\hline 5 & 1910 & 1510 & 400 & 20,9 \\
\hline
\end{tabular}

Toliau buvo nagrinejjamas pėdos trajektorijos generavimas, kai roboto kojų judesiai buvo sinchronizuoti laiko atžvilgiu. Šiuo atveju, nepriklausomai, kokio ilgio buvo pėdos trajektorija, koja visada buvo perkeliama per tą patị laiką. Taigi parametrų parinkimas atsižvelgiant i trajektorijos ilgi nebebuvo taikomas. 2.3.3 poskyryje yra aptariamas parametru parinkimas pagal pavarų elektros srovès stiprị. Toks metodas ir buvo taikomas tolimesnių imitacinių ir realių eksperimentų metu. 
3.9 lentelè. Vidutinès suvartojamos HexaV4 roboto energijos kiekio vertès judant per skirtingus paviršius

Table 3.9. Average energy consumption of HexaV4 robot locomotion over different density terrains

\begin{tabular}{|c|c|c|c|c|}
\hline Kliūčių tankiai & $E, \mathbf{J}$ & $E_{\mathrm{opt}}, \mathrm{J}$ & $E-E_{\mathrm{opt}}, \mathrm{J}$ & $\eta, \%$ \\
\hline Mažas tankis & 1551 & 1348 & 203 & 13,1 \\
\hline Vidutinis tankis & 1797 & 1507 & 290 & 16,1 \\
\hline Didelis tankis & 1851 & 1564 & 287 & 15,5 \\
\hline
\end{tabular}

Buvo atliekamas tik vieno parametro parinkimas, todèl ankstesni elektros srovès stiprio priklausomybès nuo roboto žingsnio trajektorijos aukščio ir pločio matavimai nebebuvo tinkami. Duomenys turèjo būti tikslinami. Tai buvo daroma atskiriant palaikymo ir perkèlimo fazių roboto kojai tenkančius elektros srovès stiprius.

Yra žinoma, kad roboto kojos judejjimo greitis palaikymo fazès metu sutampa su roboto pilnu judejjimo greičiu. Tačiau vienos pėdos trajektorijos laikas taip pat priklauso ir nuo eisenos, todèl norint apskaičiuoti pėdos perkèlimo nustatyta trajektorija laiką, reikalingas roboto judèjimo greitis, žingsnio trajektorijos ilgis bei eisenos periodas:

$$
t_{\text {traj }}=\frac{l}{v \cdot T},
$$

čia $t_{\text {traj }}$ - kojos perkèlimo laikas, $v$ - roboto judejjimo greitis, $l$ - žingsnio ilgis, $T$ - eisenos periodas.

3.10 lentelė. Robotui tenkančio elektros srovès stiprio priklausomybė nuo roboto žingsnio trajektorijos aukščio ir pločio. Elektros srovès stiprio vidurkiai skaičiuojami atskiriant koju palaikymo ir perkèlimo fazes

Table 3.10. Robot current consumption dependence on robot step trajectory height and width. Average current values obtained separating leg support and transfer phases

\begin{tabular}{|c|c|c|c|c|c|c|c|c|c|c|}
\hline \multirow{3}{*}{$w, \mathrm{~cm}$} & \multicolumn{10}{|c|}{$h, \mathrm{~cm}$} \\
\cline { 2 - 12 } & 1 & 2 & 3 & 4 & 5 & 6 & 7 & 8 & 9 & 10 \\
\cline { 2 - 12 } & \multicolumn{10}{|c|}{$I_{\text {vid }}, \mathrm{mA}$} \\
\hline 0 & 214 & 216 & 220 & 265 & 269 & 278 & 269 & 259 & 276 & 268 \\
\hline 1 & 226 & 215 & 251 & 220 & 260 & 272 & 232 & 280 & 236 & 258 \\
\hline 2 & 249 & 217 & 248 & 229 & 257 & 259 & 226 & 270 & 234 & 270 \\
\hline 3 & 264 & 249 & 225 & 246 & 252 & 260 & 257 & 265 & 266 & 271 \\
\hline 4 & 264 & 252 & 239 & 238 & 249 & 253 & 221 & 263 & 224 & 271 \\
\hline 5 & 279 & 247 & 250 & 245 & 239 & 257 & 256 & 260 & 257 & 261 \\
\hline 6 & 280 & 262 & 253 & 249 & 242 & 241 & 259 & 260 & 261 & 263 \\
\hline
\end{tabular}

Atliekant elektros srovès stiprio nustatymo eksperimentus su realiu robotu buvo pasirinkti šie parametrai: trikojè eisena $(T=2)$, žingsnio ilgis $l=0,04 \mathrm{~m}$, 
roboto judejjimo greitis $v=0,014 \mathrm{~m} / \mathrm{s}$, maitinimo šaltinio ịtampa $U=11 \mathrm{~V}$. İstačius turimus dydžius ì (3.3) lygtị, gaunama, kad vienos kojos perkèlimo laikas $t_{\text {traj }}=1,4 \mathrm{~s}$. Nauji elektros srovès stiprio priklausomybès nuo žingsnio trajektorijos aukščio ir pločio rezultatai pateikti 3.10 lentelèje.

Vienos roboto kojos pavaroms tenkančių elektros srovès stipriai taip pat buvo perdaryti ị dvimatę matricą ir integruoti ị imitacinị modelị.

Visų pirma buvo atliekami imitaciniai tyrimai $M A T L A B^{\circledR}$ matematinio modeliavimo aplinkoje. Pradiniai nustatymai buvo tokie: naudojama trikojè eisena $(T=2)$, žingsnio ilgis $l=0,05 \mathrm{~m}$, itampa $U=11 \mathrm{~V}$, roboto judejjimo greitis $v=0,013 \mathrm{~m} / \mathrm{s}$, numatytas nueiti atstumas $d=1 \mathrm{~m}$. Pagal šiuos duomenis gautas vienos kojos pėdos perkèlimo laikas $t_{\text {traj }}=1,3 \mathrm{~s}$.

Prieš atliekant matavimus su kliūtimis roboto kelyje, buvo atliktas vienas bandomasis matavimas be kliūčių. Vieno matavimo modeliavimo aplinkoje užtenka, nes kiekvieną kartą gaunamas tas pats rezultatas (nèra atsitiktinių dydžių). Gauta, kad nueidamas $1 \mathrm{~m}$ atstumą be kliūčių robotas suvartoja $559 \mathrm{~J}$ energijos $\left(E_{\mathrm{vid}}=18,6 \mathrm{~J}\right)$.

Atliekant tyrimus su kliūtimis, matavimų metu roboto kelyje buvo 10 kliūčių: 5 dešinèje ir 5 kairèje pusèje. Kliūčių dydžiai buvo parenkami atsitiktinai, kaip ir ankstesniuose tyrimuose, siekiant imituoti tikrą paviršių. Matavimai taip pat buvo atliekami dviem etapais: be parametru parinkimo ir su parametru parinkimu. Viso buvo atlikta 20 matavimų. Gauti rezultatai pateikti 3.11 lentelèje.

3.11 lentelė. HexaV4 šešiakojo roboto energijos sąnaudos, kai roboto kojų judesiai yra sinchronizuotos laiko atžvilgiu

Table 3.11. HexaV4 hexapod robot energy consumption, when robot leg motion is synchronizes by time

\begin{tabular}{|c|c|c|c|c|}
\hline Matavimo nr. & $E, \mathbf{J}$ & $E_{\text {opt }}, \mathbf{J}$ & $E-E_{\text {opt }}, \mathbf{J}$ & $\eta, \%$ \\
\hline 1 & 583 & 564 & 19 & 3,4 \\
\hline 2 & 589 & 566 & 23 & 4,1 \\
\hline 3 & 578 & 563 & 15 & 2,7 \\
\hline 4 & 587 & 563 & 24 & 4,3 \\
\hline 5 & 581 & 564 & 17 & 3 \\
\hline 6 & 586 & 565 & 21 & 3,7 \\
\hline 7 & 574 & 565 & 9 & 1,6 \\
\hline 8 & 582 & 563 & 19 & 3,4 \\
\hline 9 & 578 & 564 & 14 & 2,5 \\
\hline 10 & 585 & 563 & 22 & 3,9 \\
\hline Vidutinés vertes & 582 & 564 & 18 & 3,3 \\
\hline
\end{tabular}

Vidutinis kliūčių perlipimo naudojant pasiūlytą metodą efektyvumas yra 3,3 \% (3.11 lentelè). Galima teigti, kad tai yra labai mažas efektyvumas, kuris 
nesumažina energijos sąnaudų. Kai kuriais atvejais efektyvumas siekia daugiau nei $4 \%$, tačiau tai vis tiek nèra pakankamas rezultatas.

Siekiant ịvertinti metodo adekvatumą buvo atlikti trys eksperimentai su realiu robotu taikant pédos trajektorijos generavimo metodą, kai roboto kojų judesiai yra sinchronizuoti laiko atžvilgiu. Šiems eksperimentams pasirinkta banguojanti eisena ir judejimo greitis $v=0,009 \mathrm{~m} / \mathrm{s}$. Toks pasirinkimas grindžiamas tuo, kad realaus roboto judejjimas nèra idealiai tiesus, todèl banguojanti eisena ir mažas judejjimo greitis užtikrina tiesesnị ir stabilesni judejjimą. Taip pat ir kliūčiu skaičius roboto kelyje pasirinktas mažesnis: viso 6 kliūtys; po 3 kiekvienoje pusèje (3.20 pav.). Jų išdèstymas parinktas taip, kaip parodyta 2.9 paveiksle: sekant linijas, kuriomis keliaus roboto kojos. Žinant tai, buvo padaryta išvada, kad šešiakampis roboto kūnas buvo nebetinkamas tolimesniems matavimams, nes vidurinès kojos yra išdėstytos didesniu atstumu nuo kūno centro negu kampinès. Tai reiškia, kad roboto kojos ne vienodai užklius už visų kliūčių. Siekiant, kad realūs eksperimentai atitiktų visas ankstesnes sąlygas ir visos roboto kojos atsiremtų i vienodą kliūčių skaičių, roboto kūno forma buvo pakeista. Pasirinkta roboto kūną keisti ị stačiakampio formos kūną (3.21 pav.). Tokia kūno forma užtikrino, kad visos roboto kojos būtų išdèstytos vienodais atstumais nuo kūno ir lygiagrečiai viena kitai. Toks robotas buvo naudojamas tik šiuose eksperimentuose. Matavimų rezultatai pateikti 3.12 lentelèje.

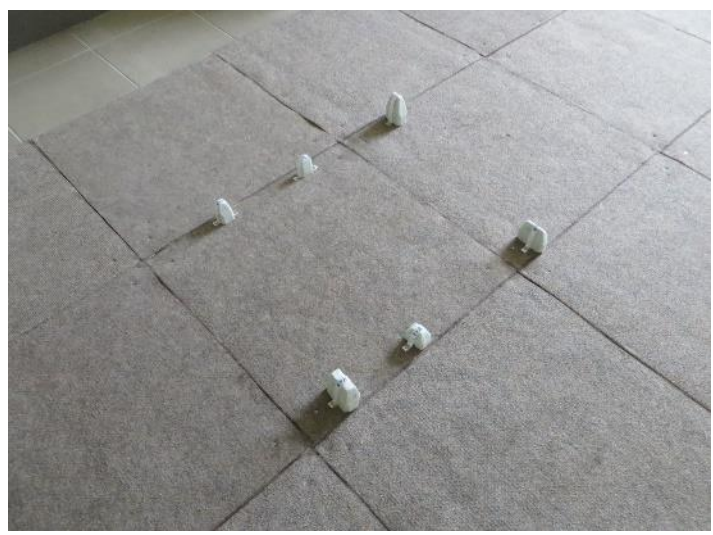

3.20 pav. Kliūčių išdèstymas energijos sąnaudų minimizavimo eksperimentams Fig. 3.20. Obstacle positioning for energy consumption minimization

Reiktų atkreipti dèmesį, kad 3.12 lentelèje pateikiami kitokie energijos dydžiai nei 3.6-3.11 lentelèse. Čia pateikiamos vidutinès energijos vertès, nes nebuvo galimybès ịvertinti pilnutinès suvartojamos energijos dèl matavimo priemonių. Šiuose eksperimentuose vietoje oscilografo buvo naudojamas Bluetooth ryšio modulis. Lyginant su ankstesniais matavimais, šių matavimų 
metu taip pat buvo gaunama 6000 elektros srovès stiprio verčių, tačiau kiekvieno matavimo trukmè buvo $30 \mathrm{~s}$, todèl intervalas tarp elektros srovès stiprio verčių buvo $5 \mathrm{~ms}$. Tai yra gerokai didesnis intervalas nei ankstesniuose matavimuose, tačiau vis tiek pakankamai mažas norint ịvertinti vidutinị elektros srovès stiprị. 3.12 lentelèje $E_{\text {vid }}$ yra vidutinè energija be parametru parinkimo, $E_{\text {vid_opt }}-$ vidutinè energija su parametru parinkimu, $E_{\text {vid }}-E_{\text {vid_opt }}-$ skirtumas tarp suvartojamos energijos su ir be parametru parinkimo. Plačiau šis metodas aprašytas 2.4 poskyryje.

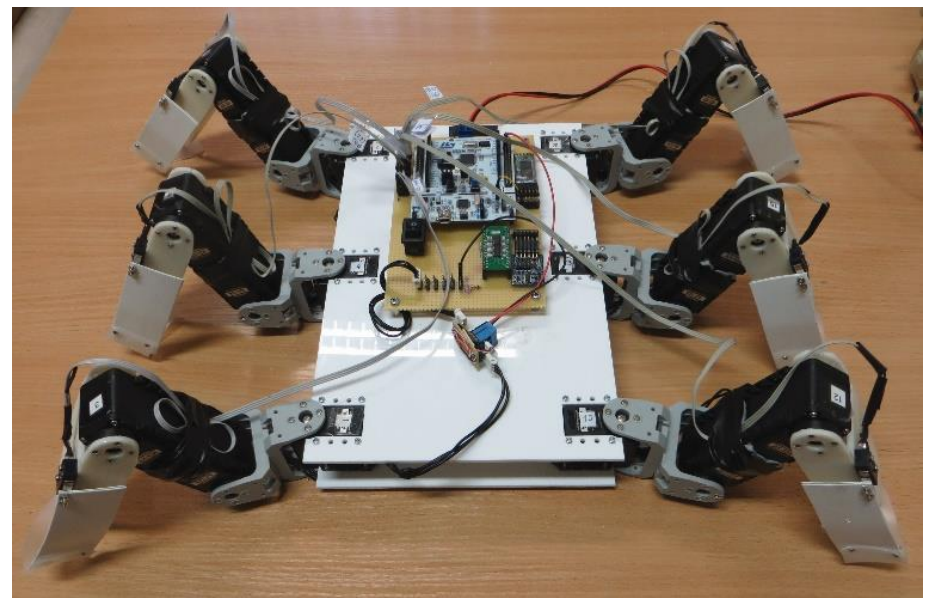

3.21 pav. Stačiakampio formos kūnas HexaV4 šešiakojui robotui

Fig. 3.21. HexaV4 hexapod robot with rectangle shaped body

3.12 lentelè. HexaV4 šešiakojo roboto energijos sąnaudos, kai kojų judesiai yra sinchronizuoti laiko atžvilgiu

Table 3.12. HexaV4 hexapod robot energy consumption, when leg motions are synchronized in time

\begin{tabular}{|c|c|c|c|c|}
\hline Matavimo nr. & $E_{\text {vid }}, \mathbf{J}$ & $E_{\text {vid opt }}, \mathbf{J}$ & $E_{\text {vid }}-E_{\text {vid opt }}, \mathbf{J}$ & $\eta, \%$ \\
\hline 1 & 14,71 & 14,44 & 0,27 & 1,9 \\
\hline 2 & 14,6 & 14,27 & 0,33 & 2,3 \\
\hline 3 & 14,7 & 14,27 & 0,43 & 3 \\
\hline
\end{tabular}

Gautas vidutinis kliūčių perlipimo metodo su parametrų parinkimu yra 2,4 \% (3.12 lentelè). Efektyvumo vertė yra panaši ị imitacinių tyrimų metu gautą rezultatą. Galima teigti, kad metodo efektyvumas pasitvirtina, tačiau dèl išorinių veiksnių, tokių kaip trintis, praslydimai, atsirèmimai ì kliūtis, oro pasipriešinimas, realus metodo efektyvumas yra mažesnis. Tokie rezultatai rodo, kad kliūčių perlipimo metodas su parametrų parinkimu, kai roboto kojų judesiai yra sinchronizuoti laiko atžvilgiu, nèra tinkamas metodas norint, kad robotas 
suvartotų mažesnį energijos kiekị. Nėra prasmès keisti kojos perkèlimo parametrų, nes suvartojamas energijos kiekis išlieka beveik nepakitęs arba pakitęs labai mažai. Tačiau iš šiame poskyryje gautų visų rezultatų matyti, kad tiek kojos perkèlimo aukštis, tiek kliūčių kiekis roboto kelyje turi įtakos energijos sąnaudoms. Tik nėra pilnai aišku, kuris parametras turi didesnę ịtaką. Tai nagrinejjama kitame poskyryje.

\subsection{Energijos sąnaudụ priklausomybès nuo kliūčių dydžio ir tankio tyrimas}

Kaip jau buvo pastebėta 3.3 poskyryje atliekant energijos sąnaudu minimizavimo judant per kliūtis tyrimo metu, energijos sąnaudos priklauso nuo kliūčių skaičiaus roboto kelyje ir nuo kliūčių dydžio (aukščio). Tačiau nèra žinoma, kaip stipriai šie parametrai ịtakoja energijos sąnaudas ir kuris parametras yra svarbesnis. Taigi šiame skyryje pateikti rezultatai tyrimų, kurių tikslas buvo ištirti vaikščiojančio roboto energijos sąnaudų priklausomybę nuo kliūčių dydžio ir tankio. Šiame darbe kliūčių tankis buvo žymimas pagal tai, kiek robotas turès perlipti kliūčių, o ne kiek kliūčių yra iš viso tam tikrame plote. Robotui perlipti reikiamų kliūčių skaičiaus susietumas su kiek iš viso aplinkoje yra kliūčių šiame darbe nebuvo nagrinejjamas, siekiant supaprastinti tyrimus ir užtikrinti žinomas sąlgyas.

3.13 lentelè. Elektros srovès stiprio priklausomybès nuo žingsnio trajektorijos aukščio identifikavimo rezultatai

Table 3.13. Current dependence on step trajectory height identification results

\begin{tabular}{|c|c|c|c|c|c|c|c|c|c|c|c|}
\hline \multirow{3}{*}{ Matavimas } & \multicolumn{10}{|c|}{$h, \mathrm{~cm}$} \\
\cline { 2 - 13 } & 1 & 2 & 3 & 4 & 5 & 6 & 7 & 8 & 9 & 10 \\
\cline { 2 - 13 } & \multicolumn{10}{|c|}{$I_{\text {vid }}, \mathrm{mA}$} \\
\hline 1 & 229 & 227 & 229 & 229 & 231 & 234 & 238 & 240 & 242 & 251 \\
\hline 2 & 234 & 237 & 233 & 231 & 235 & 239 & 242 & 241 & 241 & 245 \\
\hline 3 & 242 & 236 & 231 & 235 & 235 & 238 & 240 & 242 & 241 & 243 \\
\hline 4 & 235 & 232 & 232 & 235 & 240 & 238 & 240 & 241 & 241 & 246 \\
\hline 5 & 231 & 231 & 228 & 234 & 232 & 238 & 241 & 241 & 239 & 245 \\
\hline Vidurkis & 234 & 233 & 231 & 233 & 235 & 238 & 240 & 241 & 241 & 246 \\
\hline$\Delta I_{\text {vid- }}$ & 5 & 5 & 3 & 3 & 3 & 4 & 2 & 1 & 2 & 3 \\
\hline$\Delta$ Ivid+ & 8 & 4 & 2 & 2 & 5 & 2 & 2 & 1 & 1 & 5 \\
\hline
\end{tabular}

Buvo nustatyta, kad energijos sąnaudos beveik nepriklauso nuo kojos perkèlimo pločio, todèl šiuose tyrimuose buvo nustatyta, kad robotas kliūtis perlips keliant kojas tik per viršų. Taip pat buvo pakeistas roboto kūnas, todèl buvo atliktas naujas elektros srovès stiprio priklausomybès nuo žingsnio trajektorijos aukščio identifikavimas. Siekiant gauti tikslesnius rezultatus buvo 
atliktas didesnis matavimų kiekis: po 5 matavimus su kiekvieno žingsnio trajektorijos aukščiu.

Matavimai buvo atliekami naudojant šiuos roboto judejimo parametrus: žingsnio ilgis $l=0,05 \mathrm{~m}$, banguojanti eisena, roboto greitis $v=0,013 \mathrm{~m} / \mathrm{s}$. Gauti rezultatai buvo vidurkinami ir skaičiuojamos paklaidos. Rezultatai pateikti 3.13 lentelëje ir galutinè elektros srovès stiprio priklausomybè nuo žingsnio trajektorijos aukščio pavaizduota 3.22 paveiksle.

3.13 lentelejje dydis $\Delta I_{\text {vid- }}$ vaizduoja elektros srovès stiprio nuokrypą nuo vidutinès vertès ị žemesnę pusę, o dydis $\Delta I_{\text {vid+ }}$ - elektros srovès stiprio nuokrypą nuo vidutinès vertès ị didesnę pusę.

Elektros srovès stiprio verte didèjant žingsnio trajektorijos aukščiui didèja (3.22 pav.). Aproksimuojant gautus rezultatus galima nustatyti elektros srovės stiprio priklausomybès nuo žingsnio trajektorijos aukščio lygtị. Iš grafiko matyti, kad elektros srovès stiprio didèjimas paklaidų ribose yra tiesinis, todèl buvo pritaikyta tiesinè aproksimacija. Gauta elektros srovès stiprio priklausomybės nuo žingsnio trajektorijos aukščio lygtis:

$$
I=0,002 \cdot h+0,226 .
$$

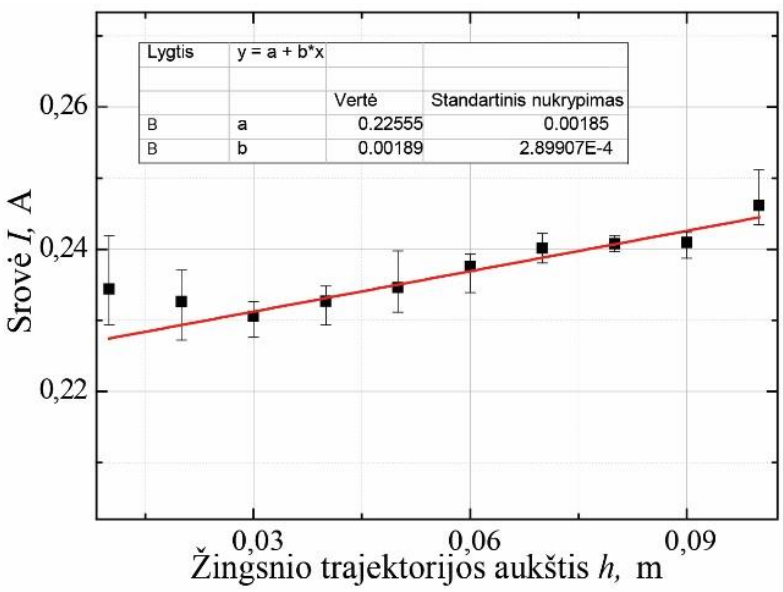

3.22 pav. Elektros srovès stiprio priklausomybè nuo žingsnio trajektorijos aukščio, kai roboto kūnas yra stačiakampio formos. Raudona linija - tiesinè aproksimacija

Fig. 3.22. Current dependence on step trajectory height when robot body is rectangle shape. Red line - linear approximation

Gauta (3.4) lygtis buvo integruota $\mathfrak{i}$ imitacini roboto modeli ir buvo naudojama robotui tenkančios elektros srovès stiprio vertei gauti pagal judejjimo parametrus kiekvienai kojai atskirai. Žinoma, norint sèkmingai perlipti kliūtis, robotas turi kelti koją i didesni aukštį, nei yra kliūties aukštis. Todèl imitacinio 
modelio programoje buvo nurodyta, kad robotas koją keltų ị $0,01 \mathrm{~m}$ didesnị aukštị nei kliūties aukštis. Taigi, žinant kliūties aukštị $H$, elektros srovès stiprio vertè parenkama pagal $h=H+0,01$ kojos perkèlimo aukštị. Taip pat šiuose tyrimuose suvartojamos energijos kiekis buvo vertinamas pagal (2.74) lygti, kurioje yra įskaičiuotas vèlinimas dèl atsitrenkimų ị kliūtis.

Prieš atliekant imitacinius tyrimus su kliūtimis buvo atlikta serija matavimu be kliūčių užduodant robotui nukeliauti skirtingus atstumus. Šie bandomieji matavimai buvo naudingi lyginant energijos sąnaudas judant lygiu paviršiumi ir perlipant kliūtis. Tyrimai buvo atliekami tokiomis pačiomis sąlygomis kaip ir elektros srovès stiprio identifikavimo eksperimentai. Robotui nukeliauti buvo numatyti šie atstumai: $1 \mathrm{~m}, 1,5 \mathrm{~m}, 2 \mathrm{~m}, 2,5 \mathrm{~m}, 3 \mathrm{~m}, 3,5 \mathrm{~m}$ ir $4 \mathrm{~m}$. Buvo matuojama pilnutinè suvartotos energijos verté $E_{\mathrm{p}}$ ir vidutinè suvartojama energijos vertè per visą nueitą atstumą $E_{\text {vid. }}$.

Gauti energijos priklausomybès nuo nueito kelio rezultatai rodo, kad energijos sąnaudos proporcingai didèja didejjant atstumui. Robotas suvartoja $\sim 1235 \mathrm{~J}$ energijos nueidamas $1 \mathrm{~m}$ atstumą, o nuejęs $4 \mathrm{~m}-\sim 4700 \mathrm{~J}$. Energijos sąnaudos padidèja $\sim 3500 \mathrm{~J}$ atstumui padidejus $3 \mathrm{~m}$. Tačiau vidutinè sunaudotos energijos verte kelio vienetui liko nepakitusi $(\sim 80 \mathrm{~J})$. Tai rodo, kad robotui judant lygiu paviršiumi, energijos sąnaudos yra stabilios. Šiuo atveju energijos sąnaudų stabilumas parodo, kad kiekvieno pilno judejimo ciklo metu pilnutinè energijos vertè padidèja tokiu pačiu energijos kiekiu.

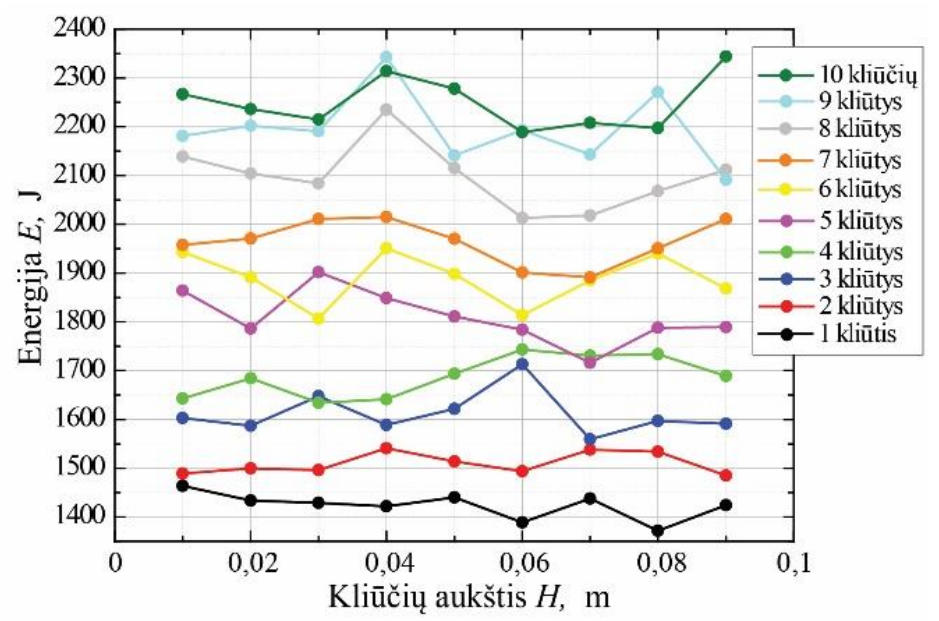

3.23 pav. Energijos sąnaudų priklausomybè nuo kliūčių aukščio esant skirtingiems kliūčių kiekiams roboto kelyje

Fig. 3.23. Energy consumption dependence on obstacle height with different number of obstacles along robot's path 
Robotas aukščiausiai kojas gali kelti tik i $0,1 \mathrm{~m}$ aukštị, todèl tolimesni tyrimai buvo atlikti tik su kliūtimis, kurių aukštis neviršija šio aukščio (t. y. $0,09 \mathrm{~m}$ arba mažesnès). Robotui visada būdavo užduodamas tas pats $1 \mathrm{~m}$ atstumas, kurị jis turi ịveikti. Kliūčių tankis buvo didinamas nuo 1 kliūties kelyje iki 10 kliūčių. Visos kliūtys buvo sutalpinamos $1 \mathrm{~m}$ kelyje, kad robotas būtinai turètų jas perlipti, tokiu būdu užtikrinant, kad kliūčių tankis neknitančiame paviršiaus plote didejja. Visų kliūčių aukščiai buvo nustatomi vienodi. Su kiekviena konfigūracija buvo atliekama po tris matavimus, nes kiekvieną kartą robotas gali sugaišti skirtingą laiką prie kiekvienos kliūties ((2.74) lygtis). Viso buvo atlikta 270 matavimų. Rezultatai vaizduojami 3.23 paveiksle.

3.14 lentelè. Vidutinès energijos sąnaudų vertès neatsižvelgiant ị kliūčių aukščius Table 3.14. Average energy values without taking obstacle heights into account

\begin{tabular}{|c|c|c|c|}
\hline $\begin{array}{c}\text { Kliūčiu skaičius } \\
K, \text { vnt. }\end{array}$ & \multicolumn{3}{|c|}{$E, \mathrm{~J}$} \\
\cline { 2 - 4 } & $E_{\text {vid }}$ & $\Delta E_{\text {vid- }}$ & $\Delta E_{\text {vid }}$ \\
\hline 1 & 1423 & 51 & 41 \\
\hline 2 & 1510 & 25 & 31 \\
\hline 3 & 1612 & 53 & 101 \\
\hline 4 & 1688 & 54 & 55 \\
\hline 5 & 1810 & 94 & 92 \\
\hline 6 & 1889 & 82 & 62 \\
\hline 7 & 1964 & 73 & 51 \\
\hline 8 & 2089 & 76 & 146 \\
\hline 9 & 2195 & 104 & 148 \\
\hline 10 & 2250 & 61 & 94 \\
\hline
\end{tabular}

Nors iš 3.22 paveikslo matyti, kad elektros srovès stipris dideja didejjant kliūčių aukščiui (taip pat turètų didèti ir suvartojama energija), tačiau iš 3.23 paveikslo akivaizdžiai matyti priešingas rezultatas, kuris rodo, kad pilnutiné suvartojamos energijos vertė nuo kliūčiu aukščio nepriklauso. Taip yra dèl to, kad elektros srovès stiprio kitimas didèjant kliūčių aukščiui yra labai mažas. Tuo labiau, kad robotas nueitu jam numatytą atstumą, jis turi atlikti tam tikrą žingsnių skaičių (pvz. 50 ar 100). Iš šių visų žingsnių, tik maža dalis jų bus skirta tam, kad perlipti kliūtis, todèl kliūčių aukštis bendram suvartojamam energijos kiekiui turi mažą įtaką.

Tačiau didejjant kliūčių kiekiui roboto kelyje, energija padidèja nuo 1460 J iki $2345 \mathrm{~J}$. Roboto energijos sąnaudos perlipant 10 kliūčių (1 m atstumas) beveik prilygsta energijos sąnaudoms robotui nukeliaujant $2 \mathrm{~m}$ atstumą be kliūčių. Taigi norint, kad robotas naudotų mažesnị energijos kiekį reikia parinkti kelią, kuriame yra mažiau kliūčių, tačiau atsižvelgti ị kliūčių dydị nėra labai svarbu. 


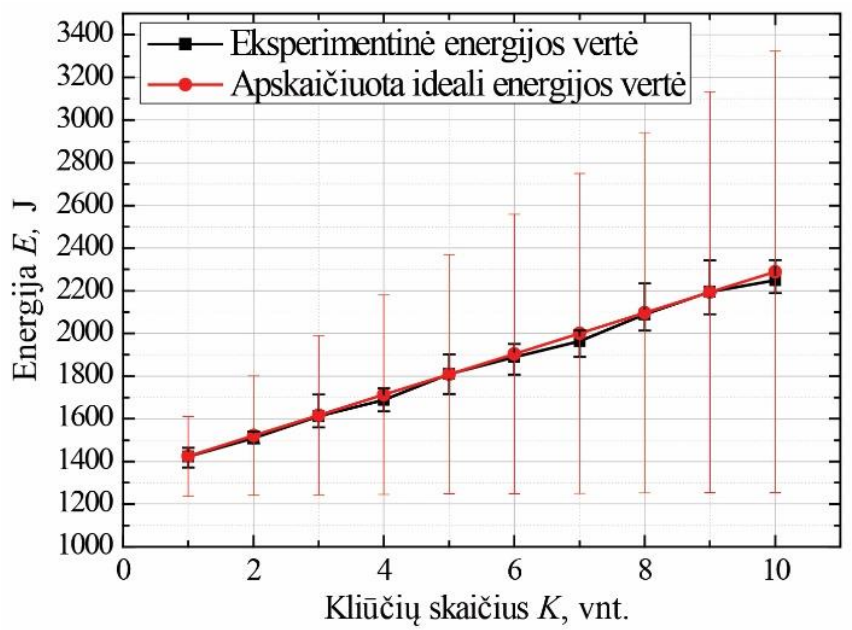

3.24 pav. Energijos sąnaudų priklausomybė nuo kliūčių tankio. Raudonos paklaidų linijos vaizduoja minimalias ir maksimalias galimas energijos vertes

Fig. 3.24. Energy consumption dependence on obstacle density. Red deviation lines represent minimum and maximum possible energy values

Naudojant (2.74) lygti buvo atlikti teoriniai energijos sąnaudų skaičiavimai, kurie buvo naudojami eksperimentinių rezultatų palyginimui. Visų pirma buvo skaičiuojamos energijos vertès esant vidutinei $\Delta t$ vertei. Šios vertès turètų būti palyginamos su vidutinėmis energijų vertėmis, gautomis bandymų metu (3.14 lentelè). Toliau buvo skaičiuojamos minimalios ir maksimalios galimos teorinès energijos vertès įstačius $\Delta t_{\min }$ ir $\Delta t_{\max }$ vertes, kurios turi parodyti, kiek robotas suvartos energijos sugaišdamas minimalų ir maksimalų laiko kieki perlipti visoms kliūtims. Tokios energijos vertès atspindi, kiek mažiausiai ir kiek daugiausiai energijos gali robotas suvartoti perlipdamas tam tikrą kliūčių skaičių. Šios vertès yra pavaizduotos kaip nukrypimai nuo vidutinès vertès 3.24 paveiksle.

Visų pirma matyti, kad imitacinių tyrimų rezultatai sutampa su teoriškai apskaičiuotomis vertėmis. Tai patvirtina, kad esant atsitiktiniam kiekvienos roboto kojos vélinimui prie kliūties, suvartojamos energijos kiekis didèja tiesiškai, priklausomai nuo kliūčių skaičiaus. Netgi paklaidų vertės niekada nesiekia minimalių ar maksimalių galimų energijos sąnaudų verčių. Tačiau svarbiausia atkreipti dèmesi $\mathfrak{i}$ apatines teorines energijos sąnaudų vertes. Jos rodo, kad teoriškai yra įmanoma robotui perlipti visas jo kelyje esančias kliūtis suvartojant minimalų energijos kiekị (prilygsta judèjimui lygiu paviršiumi). 


\subsection{Trečiojo skyriaus išvados}

1. Šešiakojo roboto energijos sąnaudos priklauso nuo eisenos ir greičio. Energetiškai efektyviausios eisenos yra banguojanti, judant mažu greičiu, ir trikojè, judant dideliu greičiu. Parenkant tinkamas eisenas priklausomai nuo roboto judejimo greičio energijos sąnaudas galimas sumažinti iki $21 \%$.

2. Perskaičiavus energijos sąnaudų vertes ị transportavimo kaštus, pastebėta, kad šešiakojo roboto judejimas yra energetiškai efektyvus tik robotui judant didesniu kaip 0,16 kūno ilgio/s greičiu. Taip pat pastebèta, kad mažiausią transportavimo kaštų vertę šešiakojui robotui pasiekti galima taikant trikoję eiseną ir judant didžiausiu galimu greičiu. Judant 1,32 kūno ilgio/s greičiu, transportavimo kaštų vertè gaunama 5,75. Tai yra vienas iš geriausių rezultatų, lyginant su kitais vaikščiojančiais robotais, kurių transportavimo kaštų vertès kinta nuo 8,9 iki 128.

3. Roboto judèjimo per kliūtis tyrimo rezultatai parodè, kad santykiniai nuokrypiai nuo numatytos trajektorijos gali siekti apie $24 \%$ netaikant kliūčių perlipimo metodo einant $1 \mathrm{~m}$ atstumą. Taikant kliūčių perlipimo metodą santykinius nuokrypius galima sumažinti iki $12 \%$. Mažiausi nuokrypiai robotui perlipant kliūtis gali būti pasiekti naudojant banguojančią eiseną einant trumpesnį atstumą.

4. Atlikus energijos sąnaudų minimizavimo su parametrų parinkimu tyrimus pastebèta, kad energijos sąnaudas galima minimizuoti parenkant pėdos trajektorijos generavimo parametrus, priklausomai nuo kliūčių dydžio. Tuo atveju, kai roboto kojų judesiai nèra sinchronizuoti laiko atžvilgiu, galima gauti iki 14,9 \% mažesnes energijos sąnaudas. Kai kojų judesiai yra sinchronizuoti laiko atžvilgiu, galima gauti iki 3,3\% mažesnes energijos sąnaudas imitacinio modelio atveju ir iki $2,4 \%$ mažesnes energijos sąnaudas su realiu robotu.

5. Energijos sąnaudų priklausomybès nuo kliūčių dydžio ir tankio tyrimo rezultatai parodé, kad energijos sąnaudos priklauso nuo kliūčių tankio aplinkoje, tačiau nuo kliūčių aukščio priklauso labai mažai $(0,00022 \mathrm{~J} / \mathrm{cm})$. Kiekviena papildoma kliūtis viename metre, nepriklausomai nuo jos dydžio, šešiakojo roboto kelyje energijos sąnaudas padidina apie $7 \%$. 



\section{Bendrosios išvados}

1. Atlikus literatūros analizę buvo pastebėta, kad vaikščiojančių robotų pagrindinis privalumas yra gebejimas judeti nelygiu paviršiumi ir prisitaikyti prie aplinkos. Taip pat buvo nustatyta, kad didžiausias vaikščiojančių robotų trūkumas, lyginant su važiuojančiais robotais, yra didelès energijos sąnaudos, kurios atsiranda dèl didelio pavarų skaičiaus ir netobulų valdymo metodų.

2. Sudarytas šešiakojo roboto matematinis modelis, kuriame yra galimybė skaičiuoti roboto energijos sąnaudas. Elektros srovès stiprio duomenys gauti atliekant tyrimus su realiu šešiakoju robotu. Modelis yra universalus ir gali būti naudojamas atliekant roboto judejjimo ir energijos sąnaudų tyrimus. Naudojant imitacinį modeli galima atlikti didesnị kiekị matavimų, o tai didina tyrimų tikslumą.

3. Vaikščiojančių robotų energijos sąnaudos priklauso nuo judejjimo greičio bei eisenos. Iki 7,7 \% mažesnes šešiakojo roboto energijos sąnaudas galima gauti taikant trikoję eiseną vietoj banguojančios, judant mažais greičiais $(0,184$ kūno ilgiai/s ar mažiau) ir iki $21 \%$ taikant banguojančią eiseną vietoj trikojès, judant dideliais greičiais $(0,184 \mathrm{kūno}$ ilgiai/s ar daugiau). Mažiausia transportavimo kaštų vertė - 5,75 gaunama, kai šešiakojis 
robotas juda trikoje eisena ir didžiausiu greičiu, kuris tirtam modeliui yra lygus 1,32 kūno ilgio/s.

4. Sukurtas kliūčių perlipimo metodas gali būti taikomas vaikščiojantiems robotams. Netaikant kliūčiu perlipimo metodo, santykiniai nuokrypiai nuo numatytos trajektorijos gali siekti iki $24 \%$ einant $1 \mathrm{~m}$ atstumą, kai tuo tarpu taikant kliūčių perlipimo metodą, santykiniai nuokrypiai nuo numatytos trajektorijos gali būti sumažinti iki $12 \%$, nepriklausomai nuo numatyto atstumo. Mažiausi nuokrypiai buvo gauti taikant banguojančią eiseną judant per paviršių su mažesniu kliūčių skaičiumi.

5. Energijos sąnaudos priklauso nuo kliūties dydžio tik tada, kai roboto kojų judesiai nèra sinchronizuoti laiko atžvilgiu. Šiuo atveju galima gauti apie $14,9 \%$ mažesnes energijos sąnaudas parenkant trumpesni pèdos trajektorijos ilgị. Jei roboto kojų judesiai yra sinchronizuoti laiko atžvilgiu, galima gauti tik apie 3,3\% mažesnes energijos sąnaudas. Šiuo atveju energijos sąnaudos stipriai priklauso nuo kliūčių skaičiaus roboto kelyje. Pastebėta, kad kiekviena papildoma kliūtis viename metre roboto kelio, nepriklausomai nuo jos dydžio, energijos sąnaudas padidina apie $7 \%$. 


\section{Literatūra ir šaltiniai}

Ackerman, J.; Seipel, J. 2011. Energetics of bio-inspired legged robot locomotion with elastically-suspended loads, 2011 IEEE/RSJ International Conference on Intelligent Robots and Systems: 203-208.

Ackerman, J.; Seipel, J. 2013. Energy efficiency of legged robot locomotion with elastically suspended loads, IEEE Transactions on Robotics 29(2): 321-330.

Agheli, M.; Nestinger, S., S. 2016. Foot force based reactive stability of multi-legged robots to external perturbations, Journal of Intelligent and Robotic Systems 81: 287-300.

Ali, F.; Shukor, A., Z., H.; Miskon, M., F.; Nor, M., K., M.; Salim, S., I., M. 2013. 3-D biped robot walking along slope with dual length linear inverted pendulum method (DLLIPM), International Journal of Advanced Robotic Systems 10(11): 1-12.

Amran, A., C.; Motoi, N.; Kawamura, A. 2013. Regeneration of LIPM bipedal walking trajectories for minimum energy consumption, 2013 IEEE International Conference on Mechatronics: 617-622.

Antoska, V.; Jovanovic, K.; Petrovic, V., M.; Bascarevic, N.; Stankovski, M. 2013. Balance analysis of the mobile anthropomimetic robot under disturbances - ZMP approach, International Journal of Advanced Robotic Systems 10(4): 1-10.

Arena, P.; Fortuna, L.; Frasca, M.; Patane, L.; Pavone, M. 2006. Realization of a CNNdriven cockroach-inspired robot, 2006 IEEE International Symposium on Circuits and Systems: 2649-2652. 
Arevalo, J., C.; Cestari, M.; Merodio, D., S.; Garcia, E. 2014. On the necessity of including joint passive dynamics in the impedance control of robotic legs, International Journal of Advanced Robotic Systems 11(7): 1-12.

Arevalo, J., C.; Merodio, D., S.; Cestari, M.; Garcia, E. 2015. Identifying ground-robot impedance to improve terrain adaptability in running robots, International Journal of Advanced Robotic Systems 12(1): 1-12.

Asif, U. 2012. Improving the navigability of a hexapod robot using a fault-tolerant adaptive gait, International Journal of Advanced Robotic Systems 9(2): 1-12.

Asif, U.; Iqbal, J. 2011. An approach to stable walking over uneven terrain using a reflex-based adaptive gait, Journal of Control Science and Engineering 2011: 1-12.

Baisch, A., T.; Ozcan, O.; Goldberg, B.; Ithier, D.; Wood, R., J. 2014. High speed locomotion for a quadrupedal microrobot, The International Journal of Robotics Research 33(8): 1063-1082.

Baisch, A., T.; Sreetharan, P., S.; Wood, R., J. 2010. Biologically-inspired locomotion of a $2 \mathrm{~g}$ hexapod robot, International Journal of Advanced Robotic Systems 12(1): 1-6.

Barai, R., K.; Nonami, K. 2008. Locomotion control of a hydraulically actuated hexapod robot by robust adaptive fuzzy control with self-tuned adaptation gain and dead zone fuzzy pre-compensation, Journal of Intelligent and Robotic Systems 23: 35-56.

Bartsch, S.; Birnschein, T.; Rommermann, M.; Hilljegerdes, J.; Kuhn, D.; Kirchner, F. 2012. Development of the six-legged walking and climbing robot SpaceClimber, Journal of Field Robotics 29(3): 506-532.

Belter, D.; Skrzypczynski, P. 2011. Rough terrain mapping and classification for foothold selection in a walking robot, Journal of Field Robotics 28(4): 497-528.

Best, G.; Moghadam, P.; Kottege, N.; Kleeman, L. 2013. Terrain classification using a hexapod robot, Proceedings of Australian Conference on Robotics and Automation: 1-8.

Bhounsule, P., A.; Corteli, J.; Grewal, A.; Hendriksen, B.; Karssen, J., G., D.; Paul, C.; Ruina, A. 2014. Low-bandwidth reflex-based control for lower power walking: $65 \mathrm{~km}$ on a single battery charge, The International Journal of Robotics Research 33(10): 1305-1321.

Bin, C., R.; Zhen, C., Y.; Qi, H., W.; Jiang, W.; Xu, M., H. 2013. Trotting gait of a quadruped robot based on the time-pose control method, International Journal of Advanced Robotic Systems 10(2): 1-7.

Birkmeyer, P.; Peterson, K.; Fearing, R., S. 2009. DASH: a dynamic 16g hexapedal robot, 2009 IEEE/RSJ International Conference on Intelligent Robots and Systems: 1-7.

Carbone, G.; Ceccarelli, M. 2008. A low-cost easy-operation hexapod walking machine, International Journal of Advanced Robotic Systems 5(2): 161-166.

Castro, X., Y., S.; Murillo, M., G.; Resendiz, L., A., P.; Castaneda, C. 2013. Kinematics of Hex-Piderix - a six-legged robot - using screw theory, International Journal of Advanced Robotic Systems 10(1): 1-8. 
Chaari, I.; Koubaa, A.; Trigui, S.; Bennaceur, H.; Ammar, A.; Shalfan, K., A. 2014. SmartPATH: an efficient hybrid ACO-GA algorithm for solving the global path planning problem of mobile robots, International Journal of Advanced Robotic Systems 11(7): 1-15.

Chai, H.; Rong, X.; Tang, X.; Li, Y. 2016. Gait-based quadruped robot planar hopping control with energy planning, International Journal of Advanced Robotic Systems 13(1): $1-13$.

Chen, G.; Jin, B.; Chen, Y. 2017. Accurate position and posture control of a redundant hexapod robot, Arabian Journal of Science and Engineering 42(5): 2031-2042.

Chen, W.; Ren, G.; Zhang, J.; Wang, J. 2012. Smooth transition between different gaits of a hexapod robot via a central pattern generators algorithm, Journal of Intelligent and Robotic Systems 67: 255-270.

Chow, Y., H.; Chung, R. 2002. VisionBug: a hexapod robot controlled by stereo cameras, Autonomous Robots 13: 259-276.

Daou, H., E.; Libourel, P., A.; Renous, S.; Bels, V.; Guinot, J., C. 2013. Methods and experimental protocols to design a simulated bio-mimetic quadruped robot, International Journal of Advanced Robotic Systems 10(5): 1-8.

Ding, L.; Gao, H.; Deng, Z.; Song, J.; Liu, Y.; Liu, G.; Iagnemma, K. 2013. Foot-terrain interaction mechanics for legged robots: modeling and experimental validation, The International Journal of Robotics Research 32(13): 1585-1606.

Ding, W.; Wang, Z.; Rovetta, A.; Zhu, J., M. 2010. Locomotion analysis of hexapod robot, Climbing and Walking Robots: 291-311.

Erden, M., S.; Leblebicioglu, K. 2007. Torque distribution in a six-legged robot, IEEE Transactions on Robotics 23(1): 179-186.

Estremera, J.; Santos, P., G.; Orozco, J., A. 2005. Neural virtual sensors for terrain adaptation of walking machines, Journal of Robotic Systems 22(6): 299-311.

Estremera, J.; Waldron, K. 2008. Thrust control, stabilization and energetics of a quadruped running robot, The International Journal of Robotics Research 27(10): 11351151.

Ferreira, C.; Santos, C., P. 2017. A sensory-driven controller for quadruped locomotion, Biological cybernetics 111: 49-67.

Fielding, M., R.; Dunlop, G., R. Omnidirectional hexapod walking and efficient gaits using restrictedness, The International Journal of Robotics Research 23(10-11): 11051110 .

Geva, Y.; Shapiro, A. 2014. A novel design of a quadruped robot for research purposes, International Journal of Advanced Robotic Systems 11(7): 1-13.

Go, Y.; Yin, X.; Bowling, A. 2006. Navigability of multi-legged robots, IEEE/ASME Transactions on Mechatronics 11(1): 1-8. 
Guang, Z., Y.; Bo, J.; Wei, L. 2015. Leg compliance control of a hexapod robot based on improved adaptive control in different environments, Journal of Central South University 22(3): 904-913.

Hameed, I., A. 2014. Intelligent coverage path planning for agricultural robots and autonomous machines on three-dimensional terrain, Journal of Intelligent and Robotic Systems 74: 965-983.

Hauser, K.; Bretl, T.; Latombe, J., C.; Harada, K.; Wilcox, B. 2008. Motion planning for legged robots on varied terrain, The International Journal of Robotics Research 27(1112): $1325-1349$.

Haynes, G., C.; Rizzi, A., A.; Koditschek, D., E. 2012. Multistable phase regulation for fobust steady and transitional legged gaits, The International Journal of Robotics Research 31(14): 1712-1738.

He, Y.; You, Z.; Wang, X. 2013. Modelling of a hybrid energy system for autonomous application, International Journal of Advanced Robotic Systems 10(10): 1-6.

Henrich, D. 1997. Fast motion planning by parallel processing - a review, Journal of Intelligent and Robotic Systems 20: 45-69.

Hobbelen, D., G., E.; Wisse, M. 2008. Ankle actuation for limit cycle walkers, The International Journal of Robotics Research 27(6): 709-735.

Hoon, J.; Kim, J., Y.; Oh, J., H. 2008. Adjustment of home posture of biped humanoid robot using sensory feedback control, Journal of Intellingent Robotic Systems 51: 421438.

Hyun, D., J.; Lee, J.; Park, S.; Kim, S. 2016. Implementation of trol-to-gallop transition and subsequent gallop on the MIT Cheetah I, The International Journal of Robotics Research 35(13): 1627-1650.

Ido, J.; Shimizu, Y.; Matsumoto, Y.; Ogasawara, T. 2009. Indoor navigation for a humanoid robot using a view sequence, The International Journal of Robotics Research 28(2): 315-325.

Irawan, A.; Nonami, K. 2011. Optimal impedance control based on body inertia for a hydraulically driven hexapod robot walking on uneven and extremely soft terrain, Journal of Field Robotics 28(5): 690-713.

Jisha, V., R.; Ghose, D. 2012. Frontier based goal seeking for robots in unkown environments, Journal of Intelligent and Robotic Systems 67: 229-254.

Juang, C., F.; Chang, Y., C.; Hsiao, C., M. 2011. Evolving gaits of a hexapod robot by recurrent neural networks with symbiotic species-based particle swarm optmization, IEEE Transactions on Industrial Electronics 58(7): 3110-3119.

Juang, C., F.; Chen, Y., H.; Jhan, Y., H. 2015. Wall-following control of a hexapod robot using a data-driven fuzzy controller learned through differential evolution, IEEE Transactions on Industrial Electronics 62(1): 611-619. 
Kalakrishnan, M.; Buchli, J.; Pastor, P.; Mistry, M.; Schaal, S. 2011. Learning, planning, and control for quadruped locomotion over challenging terrain, The International Journal of Robotics Research 30(2): 236-258.

Kaliyamoorthy, S.; Quinn, R., D.; Zill, S., N. 2005. Force sensors in hexapod locomotion, The International Journal of Robotics Research 24(7): 563-574.

Kar, D., C. 2003. Design of statically, stable walking robot: a review, Journal of Robotic Systems 20(11): 671-686.

Kar, D., C.; Issac, K., K.; Jayrajan, K. 2001. Minimum energy force distribution for a walking robot, Journal of Robotic Systems 18(2): 47-54.

Kecskes, I.; Odry, P. 2014. Optimization of PI and fuzzy-PI controllers on simulation model of Szabad(ka)-II walking robot, International Journal of Advanced Robotic Systems 11(11): 1-13.

Kim, H.; Kim, B., K. 2014. Minimum-energy trajectory generation for concerning with a fixed heading for three-wheeled omni-directional mobile robots, Journal of Intelligent and Robotic Systems 75: 205-221.

Kim, J., Y. 2015. Dynamic balance control algorithm of a six-legged walking robot, Little Crabster, Journal of Intelligent and Robotic Systems 78: 47-64.

Kim, J., Y.; Jun, B., H. 2014. Design of six-legged walking robot, Little Crabster for underwater walking and operation, Advanced Robotics 28(2): 77-89.

Kim, J., Y.; Park, I., W.; Oh, J., H. 2009. Realization of dynamic stair climbing for biped humanoid robot using force/torque sensors, Journal of Intelligent and Robotic Systems 56: $389-423$.

Kim, S.; Clark, J., E.; Cutkosky, M., R. 2006. iSprawl: design and tuning for high-speed autonomous open-loop running, The International Journal of Robotics Research 25(9): 903-912.

Kimura, H.; Fukuoka, Y.; Cohen, A., H. 2007. Adaptive dynamic walking of a quadruped robot on natural ground based on biological concepts, The International Journal of Robotics Research 26(5): 475-490.

Kohut, N., J.; Hoover, A., M.; Ma, K., Y.; Baek, S., S.; Fearing, R., S. 2011. MEDIC: a legged millirobot utilizing novel obstacle traversal, 2011 IEEE Conference on Robotics and Automation: 1-7.

Koos, S.; Cully, A.; Mouret, J., B. 2013. Fast damage recovery in robotics with the Tresilience algorithm, The International Journal of Robotics Research 32(14): 17001723.

Kottege, N.; Parkinson, C.; Moghadam, P.; Elfes, A.; Singh, S., P., N. 2015. Energeticsinformed hexapod gait transitions across terrains, 2015 IEEE International Conference on Robotics and Automation: 5140-5147.

Kruusmaa, M. 2003. Global level path planning for mobile robots in dynamic environments, Journal of Intelligent and Robotic Systems 38: 55-83. 
Kwon, O., S.; Choi, R., H.; Lee, D., H. 2012. Locomotion control of a compliant legged robot from slow walking to fast running, International Journal of Advanced Robotic Systems 9(6): 1-7.

Li, M.; Wang, X.; Guo, W.; Wang, P.; Sun, L. 2014. System design of a Cheetah robot toward ultra-high speed, International Journal of Advanced Robotic Systems 11(5): 111.

Lin, B., S.; Song, S., M. 2001. Dynamic modeling, stability, and energy efficieny of a quadrupedal walking machine, Journal of Robotic Systems 18(11): 657-670.

Lin, P., C.; Komsuoglu, H.; Koditschek, D., E. 2006. Sensor data fusion of body state estimation in a hexapod robot with dynamical gaits, IEEE Transactions on Robotics 22(5): 932-943.

Lin, Y.; Song, S., M. 1997. Learning hybrid position/force control of a quadruped walking machine using a CMAC neural network, Journal of Robotic Systems 14(6): 483-499.

Lock, R., J.; Vaidyanathan, R.; Burgess, S., C.; Quinn, R., D. 2009. Impact of passive stiffness variation on stability and mobility of a hexapod robot, 2009 IEEE/ASME International Conference on Advanced Intelligent Mechatronics: 980-986.

Long, S.; Xin, G.; Deng, H.; Zhong, G. 2014. An improved force-angle stability margin for radial symmetrical hexapod robot subject to dynamic effects, International Journal of Advanced Robotic Systems 12(5): 1-11.

Luneckas, T. 2013. Šešiakojo roboto judejjimo nelygiu paviršiumi tyrimas. Daktaro disertacija, Vilnius TECHNIKA: 1-90.

Macias, L., C.; Espinosa, C.; Loukianov, A.; Corrochano, E., B. 2017. Inverse kinematics for a 6-DOF walking humanoid robot leg, Advances in Applied Clifford Algebras 27(1): 581-597.

Mahapatra, A.; Bhavanibhatla, K.; Roy, S., S.; Pratihar, D., K. 2015. Energy-efficient inverse dynamic model of a hexapod robot, International Conference on Robotics, Automation, Control and Embedded Systems: 1-7.

Marhefka, D., W.; Orin, D., E. 1997. Gait planning for energy efficiency in walking machines, Proceedings of the 1997 IEEE International Conference on Robotics and Automation, 474-480.

Marhefka, D., W.; Orin, D., E. 1998. Quadratic optimization of force distribution in walking machines, Proceedings of the 1998 IEEE International Conference on Robotics and Automation: 477-483.

Massah, A., M., B.; Zamani, A.; Salehinia, Y.; Aliyari, M., S.; Teshnehlab, M. 2013. A hybrid controller based on CPG and ZMP for biped locomotion, Journal of Mechanical Science and Technology 27(11): 3473-3486.

Merodio, D., S.; Cestari, M.; Arevalo, J., C.; Garcia, E. 2012. Control motion approach of a lower limb orthosis to reduce energy consumption, International Journal of Advanced Robotic Systems 9(6): 1-8. 
Minati, L.; Zorat, A. 2002. A tree architecture with hierarchical data processing on a sensor-rich hexapod robot, Advanced Robotics 16(7): 595-608.

Moosavian, S., A.; Dabin, A. 2010. Dynamics and planning for stable motion of a hexapod robot, IEEE/ASME International Conference on Advanced Intelligent Mechatronics: 818-823.

Mostafa, K.; Chiang, J., Y.; Wei, K., T.; Her., I. 2015. Image-based method for determining better walking strategies for hexapods, International Journal of Advanced Robotic Systems 12(5): 1-12.

Nishii, J. 1998. Gait pattern and energetic cost in hexapods, Proceedings of the 20th Annual International Conference of the IEEE Engineering in Medicine and Biology Society 20(5): 2430-2433.

Okada, T.; Botelho, W., T.; Shimizu, T. 2010. Motion analysis with experimental verification of the hybrid robot PEOPLER-II for reversible switch between walk and roll on demand, The International Journal of Robotics Research 29(9): 1199-1221.

Omer, A.; Hashimoto, K.; Lim, H.; Takanishi, A. 2014. Study of bipedal robot walking motion in low gravity: investigation and analysis, International Journal of Advanced Robotic Systems 11(9): 1-14.

Parasuraman, S.; Hang, F., J.; Khan, M., K., A., A. 2012. Robot-crawler: statically balanced gaits, International Journal of Advanced Robotic Systems 9: 1-9.

Parker, G.; Zbeda, R. 2014. Learning area coverage for a self-sufficient hexapod robot using a cyclic genetic algorithm, IEEE Systems Journal 8(3): 778-790.

Robotis. 2006. Dynamixel AX-12, User's manual, [http://www.trossenrobotics.com/images/productdownloads/AX-12\%28English\%29.pdf]

Rodriguez, A., G., G.; Rodriguez, A., G.; Garcia, F., C. 2014. Improving the energy efficiency and speed of walking robots, Mechatronics 24: 476-488.

Roennau, A.; Dillmann, R. 2011. On-board energy consumption estimation for a sixlegged walking robot, 14th International Conference on Climbing and Walking Robots and the Suport Technologies for Mobile Machines: 1-9.

Roy, S., S.; Pratihar, D., K. 2011. Dynamic modeling and energy consumption analysis of crab walking of a six-legged robot, 2011 IEEE Conference on Technologies for Practical Robot Applications: 82-87.

Roy, S., S.; Pratihar, D., K. 2014. Kinematics, dynamics and power consumption analyses for turning motion of a six-legged robot, Journal of Intelligent and Robotic Systems 74: 663-688.

Run, B., C.; Zheng, C., Y.; Jian, W.; Xu, M., H. 2013. Inverse kinematics of a new quadruped robot control method, International Journal of Advanced Robotic Systems 10(1): $1-8$. 
Saito, K.; Takato, M.; Sekine, Y.; Uchikoba, F. 2012. Biomimetics micro robot with active hardware neural networks locomotion control and insect-like switching behaviour, International Journal of Advanced Robotic Systems 9: 1-6.

Santos, J.; Fernandez, P. 2017. Evolved synaptic delay based neural controllers for walking patternsin hexapod robotic structures, Natural Computing 16(2): 201-211.

Santos, P., G.; Garcia, E.; Ponticelli, R.; Armada, M. 2009. Minimizing energy consumption in hexapod robots, Advanced Robotics 23(6): 681-704.

Saranli, U.; Buehler, M.; Koditschek, D., E. 2001. Rhex: a simple and highly mobile hexapod robot, The International Journal of Robotics Research 20(7): 616-631.

Schilling, M.; Cruse, H.; Arena, P. 2007. Hexapod walking: an expansion to walknet dealing with leg amputations and force oscillations, Biological Cybernetics 96: 323-340.

Schilling, M.; Hoinville, T.; Schmitz, J.; Cruse, H. 2013. Walknet, a bio-inspired controller for hexapod walking, Biological Cybernetics 107: 397-419.

Seven, U.; Akbas, T.; Fidan, K., C.; Erbatur, K. 2012. Bipedal robot walking control on inclined planes by fuzzy reference trajectory modification, Soft Computing 16: 19591979.

Shih, T., S.; Tsai, C., S.; Her, I. 2012. Comparison of alternative gaits for multiped robots with severed legs, International Journal of Advanced Robotic Systems 9(4): 1-8.

Shkolnik, A.; Levashov, M.; Manchester, I., R.; Tedrake, R. 2011. Bounding on rough terrain with the LittleDog robot, The International Journal of Robotics Research 30(2): $192-215$.

Silva, M., F.; Machado, J., T. 2011. A literature review on the optimization of legged robots, Journal of Vibration and Control 18(12): 1753-1767.

Siregar, H., P. 2005. Simulation of power consumption for walking robot, Fifth International Workshop on Robot Motion and Control: 27-32.

Spenko, M., J.; Haynes, G., C.; Saunders, J., A.; Cutkosky, M., R.; Rizzi, A., A. 2008. Biologically inspired climbing with hexapedal robot, Journal of Field Robotics 25(4-5): 223-242.

Sprowitz, A.; Tuleu, A.; Vespignani, M.; Ajallooeian, M.; Badri, E.; Ijspeert, A., J. 2013. Towards dynamic trot gait locomotion: design, control, and experiments with Cheetah-cub, a compliant quadruped robot, The International Journal of Robotics Research 32(8): 932-950.

Tang, Y.; Ma, S.; Sun, Y.; Ge, D. 2015. Planar legged walking of a passive-spine hexapod robot, Advanced Robotics 29(23): 1-16.

Texas Instruments. 2005. High-side measurement current shunt monitor, [http://www.ti.com/lit/ds/symlink/ina139.pdf].

Vanderborght, B.; Lefeber, R., V., H., D.; Hollander, T., G., S., K., W. 2009. Comparison of mechanical design and energy consumption of adaptable, passivecompliant actuators, The International Journal of Robotics Research 28(1): 90-103. 
Walas, K. 2015. Terrain classification and negotiation with a walking robot, Journal of Intelligent and Robotic Systems 78: 401-423.

Wang, S.; Zhu, Q.; Xiong, R.; Chu, J. 2014. Fexible robotic spine actuated by shape memory alloy, International Journal of Advanced Robotic Systems 11(4): 1-11.

Wang, W., J.; Chou, H., G.; Chen, Y., J.; Lu, R., C. 2017. Fuzzy contol strategy for a hexapod robot walking on an incline, International Journal of Fuzzy Systems: 1-15.

Wang, Z.; Ding, X.; Rovetta, A.; Giusti, A. 2011. Mobility analysis of the typical gait of a radial symmetrical six-legged robot, Mechatronics 21: 1133-1146.

Wei, D.; Ge, W. 2014. Research on one bio-inspired jumping locomotion robot for searcg and rescue, International Journal of Advanced Robotic Systems 11(10): 1-10.

Weihei, C.; Guanjiao, R.; Jianhua, W.; Dong, L. 2014. An adaptive locmotion controller for a hexapod robot: CPG, kinematics and force feedback, Science China 57(11): 1-18.

Weingarten, J., D.; Groff. R., E.; Koditschek, D., E. 2004. A framework for the coordination of legged robot gaits, Proceedings of the 2004 IEEE Conference on Robotics, Automation and Mechatronics: 679-686.

Wooden, D.; Malchano, M.; Blankespoor, K.; Howard, A.; Rizzi, A., A.; Raibert, M. 2010. Autonomous navigation for BigDog, IEEE International Conference on Robotics and Automation: 4736-4741.

Wu, J.; Qiao, G.; Ge, J.; Sun, H.; Song, G. 2012. Automatic battery swap system for home robots, International Journal of Advanced Robotic Systems 9(6): 1-9.

Wu, X.; Li, Y.; Zhou, C.; Gao, Q.; Teng, W. 2011. Life extending minimum-time path planning for hexapod robot, International Journal of Advanced Robotic Systems 8(2): 16.

Wu, X.; Teng, L.; Chen, W.; Ren, G.; Jin, Y.; Li, H. 2013. CPGs with continuous adjustment of phase difference for locomotion control, International Journal of Advanced Robotic Systems 10(6): 1-13.

Xiong, X.; Worgotter, F.; Manoonpong, P. 2015. Adaptive and energy efficient walking in a hexapod robot under neuromechanical control and sensorimotor learning, IEEE Transactions on Cybernetics: 1-14.

Xin, G.; Deng, H.; Zhong, G.; Wang, H. 2015. Hierarchical kinematic modelling and optimal design of a novel hexapod robot with integrated limb mechanism, International Journal of Advanced Robotic Systems 12(9): 1-14.

Xin, R.; Xiao, N. 2009. A novel compound biped locomotion algorithm for humanoid robots to realize biped walking, Journal of Control Theory and Applications 7(1): 2328.

Yamasaki, F.; Hosoda, K.; Asada, M. 2002. An energy consumption based control for humanoid walking, Proceedings of the 2002 IEEE/RSJ International Conference on Intelligent Robots and Systems: 2473-2477. 
Yang, W.; Kim, H.; You, B., J. 2013. Biologically inspired self-stabilizing control for bipedal robots, International Journal of Advanced Robotic Systems 10(2): 1-12.

Yildirim, S. 2008. A proposed hybrid neural network for position control of a walking robot, Nonlinear Dynamics 52(3): 207-215.

Yoneda, K.; Ota, Y. 2003. Non-bio-mimetic walkers, The International Journal of Robotics Research 22(3-4): 241-249.

Zambrano, J., H., B.; Huitzil, C., T.; Girau, B. 2012. Configurable embedded CPG-based control for robot locomotion, International Journal of Advanced Robotic Systems 9(3): $1-12$.

Zenker, S.; Aksoy, E., E.; Goldschmidt, D.; Worgotter, F.; Manoonpong, P. 2013. Visual terrain classification for selecting energy efficient gaits of a hexapod robot, 2013 IEEE/ASME International Conference on Advanced Intelligent Mechatronics: 577-584.

Zielinska, T. 2015. Walking machines for exploration - optimizing the energy spendings, Proceedings of the 10th International Workshop on Robot Motion and Control: $124-129$.

Zhang, R.; Latombe, J., C. 2013. Capuchin: a free-climbing robot, International Journal of Advanced Robotic Systems 10(4): 1-18.

Zhang, T.; Wei, Q.; Ma, H. 2013. Position/force control for a single leg of a quadruped robot in an operation space, International Journal of Advanced Robotic Systems 10(2): $1-6$.

Zhang, X.; Zheng, H.; Chen, L. 2006. Gait transition for a quadrupedal robot by replacing the gait matrix of a central pattern generator model, Advanced Robotics 20(7): 849-866.

Zhang, Z., G.; Kimura, H.; Fukuoka, Y. 2006. Autonomously generating efficient running of a quadruped robot using delayed feedback control, Advanced Robotics 20(6): 607-629.

Zhou, C. 2000. Neuro-fuzzy gait synthesis with reinforcement learning for a biped walking robot, Soft Computing 4: 238-250. 


\section{Autoriaus mokslinių publikacijų disertacijos tema sąrašas}

\section{Straipsniai recenzuojamuose mokslo žurnaluose}

Luneckas, M.; Luneckas, T.; Udris, D. 2018. Leg placement algorithm for foot impact force minimization, International Journal of Advanced Robotic Systems 15(1): 1-10. ISSN 1729-8814.

Valaitis, V.; Luneckas, T.; Luneckas, M.; Udris, D. 2015. Minimizing hexapod robot foot deviations using multilayer perceptron, International Journal of Advanced Robotic Systems 12(12): 1-8. ISSN 1729-8806.

Luneckas, M.; Luneckas, T.; Gavelis, V.; Valaitis, V.; Udris, D. 2015. Piezoelectric force sensors for hexapod transportation platform, Transport: special issue on smart and sustainable transport 30(3): 294-297. ISSN 1648-4142.

Luneckas, M.; Luneckas, T.; Udris, D.; Ferreira, N., M., F. 2014. Hexapod robot energy consumption dependence on body elevation and step height, Elektronika ir elektrotechnika 20(7): 7-10. ISSN 1392-1215.

Luneckas, M.; Luneckas, T. 2014. Šešiakojo roboto energijos sąnaudu priklausomybės nuo skirtingų eisenu ir greičio judant lygiu paviršiumi tyrimas, Mokslas - Lietuvos ateitis: elektronika ir elektrotechnika; Science - future of Lithuania: Electronics and electrical engineering T. 6, Nr. 2: 194-197. ISSN 2029-2341. 


\section{Straipsniai kituose leidiniuose}

Skaburskyte, A.; Luneckas, M.; Luneckas, T.; Kriaučiūnas, J.; Udris, D. 2016. Hexapod robot gait stability investigation, 2016 IEEE 4th workshop on Advances in Information, Electronic and Electrical Engineering (AIEEE): proceedings of the 4th IEEE workshop: 1-4. ISBN 9781509044733.

Esteban, D., D.; Luneckas, M.; Luneckas, T.; Kriaučiūnas, J.; Udris, D. 2016. Statically stable hexapod robot body construction, 2016 IEEE 4th workshop on Advances in Information, Electronic and Electrical Engineering (AIEEE): proceedings of the 4th IEEE workshop: 1-4. ISBN 9781503044733.

Luneckas, M.; Luneckas, T.; Udris, D. 2013. Hexapod walking robot energy consumption dependence on the number of legs set on the surface, ECT-2013: proceedings of the 8th international conference on electrical and control technologies 25-28. ISSN 1822-5934.

Luneckas, T.; Luneckas, M.; Udris, D. 2013. Real-time online feet trajectory generation method for hexapod robot, Solid State Phenomena: Mechatronic Systems and Materials VI: Selected, peer reviewed papers from the 9th International Conference on Mechatronic Systems and Materials (MSM 2013): 148-152. ISBN 9783038352273. 


\section{Summary in English}

\section{Introduction}

\section{Problem formulation}

Legged robots are most suitable for walking over irregular terrain, locomotion in complex and human dangerous environments, due to the number of legs and high number of degrees of freedom (DOF) (G. C. Haynes et. al. 2012, X. Xiong et. al. 2015). High number of DOF increases the capabilities of walking robots, their flexibility, and the ability to overcome irregular terrain. All bipeds, quadrupeds, hexapods and octopods robots can have up to twenty or in some cases even more DOF. Each additional DOF is created using more motor, which is why energy consumption highly increases. Decreasing number of DOF also decreases robot's maneuverability and legs work zone. Because of that, energy consumption should be minimized using different type of solutions, for example, by optimizing robot's motion. Locomotion over irregular terrain or obstacle avoidance require environment recognition sensors, as well as adaptive locomotion methods. Such locomotion should include the selection of movement parameters and gaits. Hence, to develop an energy efficient methods for walking robots, it is necessary to investigate the energy consumption dependence on robot movement parameters and obstacle size and density.

The development of energy efficient method for locomotion over even terrain problem related to gait selection according to robot's movement speed is solved. The solution of this problem requires thorough investigation of energy consumption 
dependence on robot's gait and movement speed in order to understand the relation between these parameters.

Foot path planning is a commonly used method for locomotion over obstacles (M. Kalakrishnan et. al. 2011), which basically calculates positions for each robot's leg through out the whole movement trajectory. Using this method, robot has a priori information about the position of each leg every moment during movement. However, the disadvantage of such method is calculation time, especially if it is done during real time, which highly decreases robot's movement speed. Different methods for obstacle detection and avoidance could be used, such as selection of foot trajectory parameters or foot trajectory transformation. These methods are much less complex and can be used real-time without changing robot's movement speed.

In this dissertation, energy consumption dependence on robot's gait is investigated and problems of developing obstacle detection and avoidance are solved. The methods and results were used for energy efficient hexapod robot locomotion in known environment, when robot has prior information about the sizes of the obstacles.

\section{Relevance of the thesis}

Energy efficient locomotion - the most important problem of legged robots, which includes subjects of robot construction and control. This type of problem is closely related to walking parameter optimization. Results obtained from solving this problem has great importance for development of energetically efficient locomotion methodology for walking robots.

Solving energy efficient locomotion problem, robot construction problems arise. There is no general methodology, that could be used for energetically efficient robots construction. Ordinary development of any walking robot does not show any energy efficient results, because the number of DOF and energy consumption of motors is not taken into account. Also, energy consumption problems arise during locomotion over even and irregular terrain. Methods, such as inverse kinematics and inverse dynamics are essiantial, however, they also give no information about robot's energetic efficiency. During locomotion over irregular terrain, various environmental recognition systems are required, which also increase energy consumption. This is the reason why it is necessary not only to improve robot's control, but also to improve robot's energetic efficiency.

There are different types of walking robots: biped, quadruped, hexapod or even with higher number of legs. Robots can be controlled using only kinematic methods, or using both kinematics and dynamics. By carrying out robot's energetic efficiency investigation during locomotion over even terrain and during obstacle avoidance, it is possible to develop a general methodology for energy efficient walking robot locomotion, which is not dependent on robot structure, control system, or control algorithm.

\section{The object of research}

Object of research - hexapod walking robot control method for locomotion over even terrain and obstacle detection and avoidance. 


\section{The aim of the thesis}

The main purpose of the thesis is to develop and investigate energy consumption minimization methods for walking robots, used for locomotion over even terrain and obstacle avoidance.

\section{The objectives of the thesis}

To accomplish the main aim of the thesis, the following objectives have to be solved:

1. To develop hexapod robot imitational and physical models and to develop foot trajectory generation mathematical expressions for obstacle avoidance.

2. To investigate energy consumption during locomotion over even terrain and to evaluate movement deviations from given trajectory while walking over terrains with different obstacle sizes and densities.

3. To develop and investigate foot trajectory generation method, that could be used to select the most suitable leg transfer parameters using energy consumption minimization.

4. To investigate robot's energetic efficiency while moving over terrains with different size and density obstacles using developed foot trajectory generation method.

\section{Research methodology}

In this thesis, geometric calculation and Denavit-Hartenberg methods are used to develop hexapod robot inverse kinematics, parameter selection method for energy consumption minimization during obstacle avoidance investigation as well as imitation and experimental evaluation methods are used.

\section{Scientific novelty of the thesis}

During the preparation of dissertation the following results novel to electrical and electronic engineering were obtained:

1. Hexapod walking robot gait switching algorithm depending on movement speed was developed, which can be used to minimize energy consumption during locomotion over even terrain.

2. Novel obstacle detection and avoidance method for walking robots was developed, which can be used to detect and overcome obstacles during real time. 
3. Foot trajectory generation method was developed which can be used to overcome known size obstacles and to select the most suitable movement parameters for energy consumption minimization.

\section{Practical value of the research findings}

1. Hexapod walking robot mathematical model was formatted, which can be used to evaluate the effectiveness and adequacy of developed methods. This model stands out by the possibility to calculate energy consumption of walking robots.

2. Physical model of hexapod robot was constructed, which can be used to perform hexapod walking robot's locomotion and energy consumption scientific research.

3. Current sensor was selected for measuring current consumption of the mobile robot, which is necessary to evaluate energy consumption.

4. Obstacle detection sensors were constructed, which are mounted on the front sides of robot legs. These sensors can be used to detect the moment robot's legs are touching the obstacle.

\section{The defended statements}

1. By using gait switching algorithm depending on robot movement speed during locomotion over even terrain up to $21 \%$ lower energy consumption can be obtained by using wave and tripod gaits, compared to energy consumption without using gait selection algorithm.

2. Without using obstacle avoidance method average deviations from given trajectory can reach up to $24 \%$. By using obstacle avoidance method for hexapod robot average deviations from given trajectory can be minimized down to $12 \%$.

3. Using foot trajectory generation method for locomotion over various known size obstacles up to $15 \%$ lower energy consumption can be obtained, compared to locomotion without using foot trajectory generation method.

4. Obstacle density has a strong influence on robot's energy consumption (around $83 \mathrm{~J} /$ obstacle), however obstacle size has a very small influence on robot's energy consumption (around $0.00022 \mathrm{~J} / \mathrm{cm}$ ), if obstacle size is smaller than robots size. Every additional obstacle in one meter of hexapod robot's path increases energy consumption by around $7 \%$.

\section{Approval of the research findings}

The research results are published in 9 scientific publications. 4 of them are published in Claravite Analytics Web of Science data base journals with impact factor, 3 - Claravite Analytics Web of Science data base "Conference Proceedings" articles, and 2 - other peer-reviewed science data bases. The main results of the thesis are presented in the following 7 scientific conferences in Lithuania and abroad:

- international conference “iROS2017", 2017, Vancouver, Canada; 
- foreign conference "Engineering and evolution of the bio-hybrid societies" 2017, Graz, Austria;

- 4th international conference "Advances in Information, Electronic and Electrical Engineering (AIEEE)“, 2016, Vilnius, Lithuania;

- foreign conference "From bio-inspired to bio-hybrid (robotic) systems", 2016, Lausanne, Switzerland;

- annual national conference "Science - Future of Lithuania", 2014-2015, Vilnius, Lithuania;

- 8th international conference "ECT-2013: 8th international conference on electrical and control technologies ", 2013, Kaunas, Lithuania.

During 2014 year, "Myorobotics Winter School and Workshop" winter school in Cambridge, England was attended. During 2016 year, "From bio-inspired to bio-hybrid (robotic) systems " winter school in Lausanne, Switzerland was attended. Also, in year 2016 doctoral internship in Carlos III University of Madrid in Madrid, Spain was carried out. Year 2017, "Engineering and evolution of bio-hybrid societies " summer school in Graz, Austria was attended. Finally, in year 2015-2016 PhD stipend financed by Research Counsil of Lithuania for scientific accomplishments was received.

\section{Structure of the dissertation}

The dissertation consists of introduction, three chapters and general conclusions.

The dissertation consists of 125 pages, where: 47 figures, 16 tables, and 96 numerated equations are used. In total 136 references are cited in the thesis.

\section{Mobile robots' energetic efficiency analysis}

Walking robots, their types, construction, and control methods are reviewed. Energy consumption causes and increase reasons are discussed as well as energy consumption measurement methods, calculation and optimization used for various mobile robots.

Walking robots have been investigated for over 40 years and there are many different walking robots created varrying not only by construction, but also by purpose and control. Compared to wheeled robots, the most unique advantage of walking robots is their ability to overcome irregular terrain. Because of this, walking robots can be used for rescue operations, demining, payload carrying, planetary and underwater exploration.

However, walking robots are much more complex machines compared to wheeled or tracked vehicles and require more accurate control methods to sustain stability, obtain needed speed, and to use minimum energy consumption.

All walking robots can be categorized either by number of legs (bipeds, tripeds, quadrupeds, hexapods, octopods) or by shape of the body (rectangular, hexagon, square, circular, shapeless). And because all walking robots have different number of legs, their construction is dependent on the construction of legs. Each robot has a different number of degrees of freedom (DOF) which indicates robot's maneuverability.

Despite robot's construction, every walking robot requires control algorithm. Most common methods are: kinematics, inverted kinematics, dynamics, and inverted dynamics. To increase accuracy proportional-integral-derivative (PID) method is also 
used. Some robots are controlled by using central pattern generator (CPG) which is found in living organisms. Another popular control method is fuzzy logic which is very universal and can be used to solve various locomotion problems.

One of the biggest issues with walking robots is high energy consumption. There are a few reasons for that. First, most of the walking robots have high number of DOF which means that they have a large number of actuators. Another reason is robot's mass due to large number of construction parts. Finally, some robots use complex control systems with a lot of electronics components which can lead to high energy consumption. Although, this reason is not always the case.

In order to observe robot's energy consumption, one of the energy consumption and calculation methods must be used. There aren't many methods that can be used for robot's energetic evaluation.

One of the simplest and common method is to observe robot's current consumption. For this, current sensor is used, because voltage is always the same. Another method to evaluate overall energetic efficiency is to calculate cost of transport using robot's mass, power consumption, gravity and movement speed. This method is very universal because it can be used for evaluating energy consumption of animals, insects, any kind of vehicles. A more complex methods are: mechanical method which requires joint torques, and linear force which requires to integrate force and coordinates multiplication.

There are many different ways of minimizing energy consumption of walking robots. One of the possible ways is by calculating force distribution between robot's feet. Minimum force distribution leads to least energy consuming poses for robot. Also, robot's construction has a huge influence on energy consumption. Using light weight parts or a minimal amount of actuators is essential for walking robots. Another way of minimizing energy consumption is by developing robots according to living organisms found in nature. Because animals and insects evolve the best locomotion and survival behaviour, it is possible to mimic such methods for robots. In some other cases, special recharge stations are created for robots to get back to and to recharge their battery. This way robot is able to observe its own energy and return to recharge when needed. Finally, path planning methods are developed to obtain minimum energy consuming movement trajectories when robot has to cover large territory.

\section{Formation of energy efficient locomotion methods}

A hexapod walking robot that has 3 DOF on each leg is used in this research. This is the reason for using geometrical method to develop inverse kinematics for this robot (Fig. S2.1). However, to complete full imitational model, Denavit-Hartenberg method is also used and results are implemented into $M A T L A B^{\circledR}$ simulation program (Fig. S2.2). 


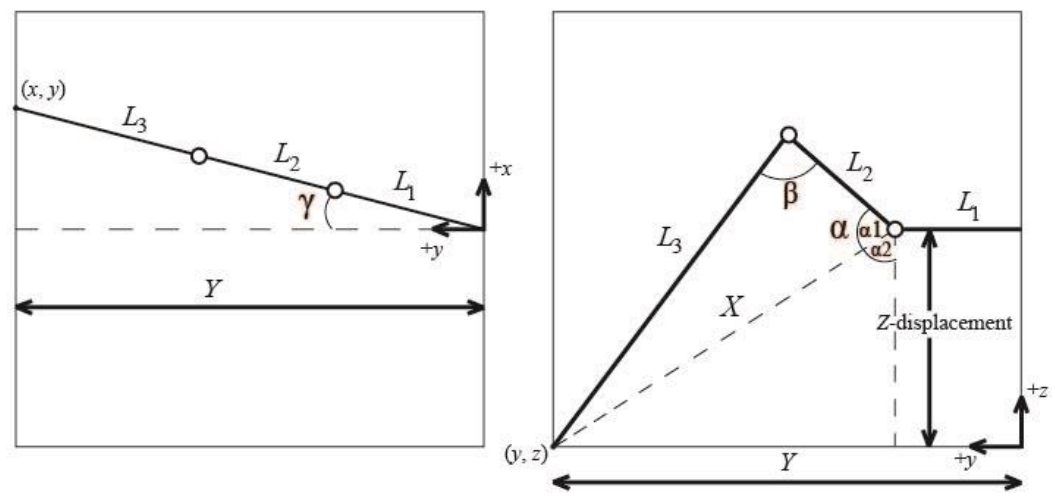

Fig. S2.1. Simplified trigonometric problem of a 3-DOF robotic leg

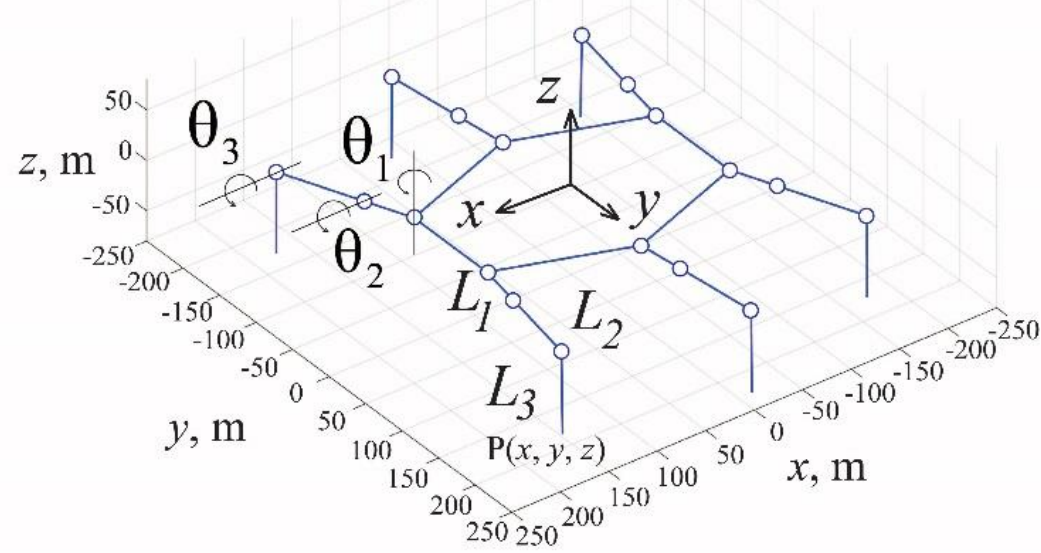

Fig. S2.2. Hexapod robot kinematic model inside $M A T L A B^{\circledR}$ program

Foot trajectory generation method is developed by splitting leg motion into separate coordinate time dependencies (Fig. S2.3):

$$
x(t)= \begin{cases}-\cos (\varepsilon) \cdot\left(\frac{l \cdot\left(T-2 \cdot \varphi_{i}+2 \cdot t-1\right)}{2 \cdot(T-1)}+\frac{l}{2}\right), & \text { kai } t \leq \varphi_{i}, \\ \cos (\varepsilon) \cdot l \cdot\left(T-\varphi_{i}\right), & \text { kai } \varphi_{i}<t \leq \varphi_{i}+1, \\ \cos (\varepsilon) \cdot\left(\frac{l \cdot\left(T+2 \cdot \varphi_{i}-2 \cdot t+1\right)}{2 \cdot(T-1)}+\frac{l}{2}\right), & \text { kai } t>\varphi_{i}+1,\end{cases}
$$




$$
y(t)= \begin{cases}-\sin (\varepsilon) \cdot\left(\frac{l \cdot\left(T-2 \cdot \varphi_{i}+2 \cdot t-1\right)}{2 \cdot(T-1)}+\frac{l}{2}\right), & \text { kai } t \leq \varphi_{i}, \\ \sin (\varepsilon) \cdot\left(l \cdot\left(t-\varphi_{i}\right)\right), & \text { kai } \varphi_{i}<t \leq \varphi_{i}+1, \\ \sin (\varepsilon) \cdot\left(\frac{l \cdot\left(T+2 \cdot \varphi_{i}-2 \cdot t+1\right)}{2 \cdot(T-1)}+\frac{l}{2}\right), & \text { kai } t>\varphi_{i}+1, \\ z(t)= \begin{cases}0, & \text { kai } t \leq \varphi_{i}, \\ h \cdot \sin \left(\left(t-\varphi_{i}\right) \cdot \pi\right), & \text { kai } \varphi_{i}<t \leq \varphi_{i}+1, \\ 0, & \text { kai } t>\varphi_{i}+1 .\end{cases} \end{cases}
$$

Also, most common hexapod robot gaits used in this research are described: tripod gait, tetrapod gait, wave gait, and ripple gait.

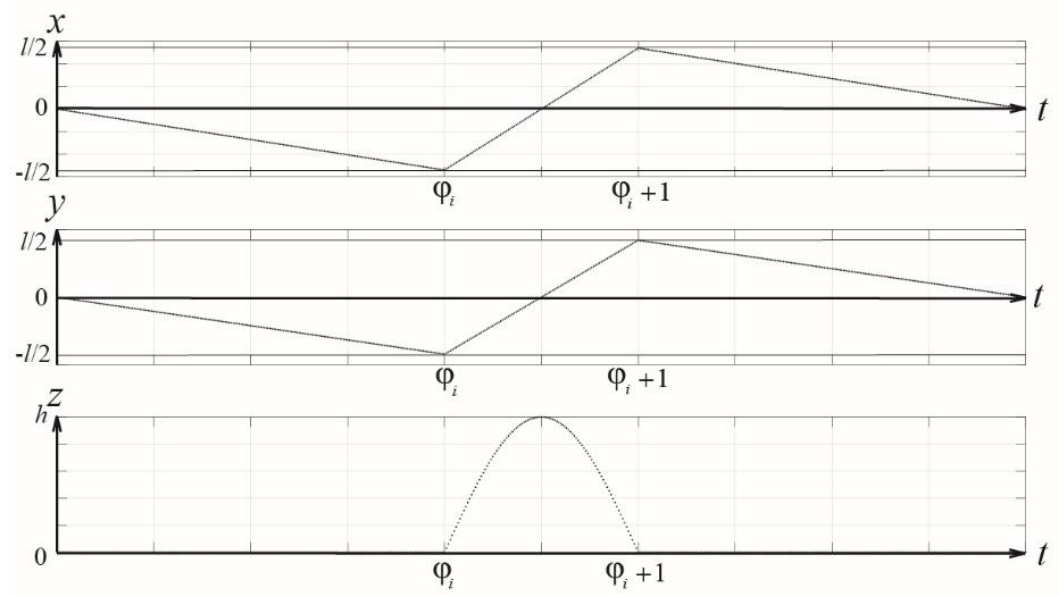

Fig. S2.3. Robot's foot trajectory separate coordinate dependence on time; $\varphi_{1}-i$-th leg's phase

Irregular terrain is compared to obstacles and the description for both are given. The obstacles are separated into two groups: important obstacles and unimportant obstacles, and are categorized by their length, height, and width. To understand the relation between obstacle sizes and the possibilities of the robot, obstacle sizes are classified into these categories: even terrain, small obstacles, average obstacles, and large obstacles. In addition, the terrain is also categorized by obstacle density and sizes. Four types of terrain complexities are used: small number of small obstacles, large number of small obstacles, small number of large obstacles, and large number of large obstacles.

To detect obstacles that are in front of the robot, tactile sensors are used on each of robot's leg, positioned on tibia part of the legs. Through out the development of sensors, three versions were tested until final solution was obtained that suited the robot 
(Fig. S2.4). Tactile sensors were combined of push-button, soft plastic material, and silicon between robot foot and plastic to avoid getting stuck on obstacles. The advantage of this method is that the prior information about the obstacle positions is not needed. However, the size of obstacles is programmed directly into robot's control program.

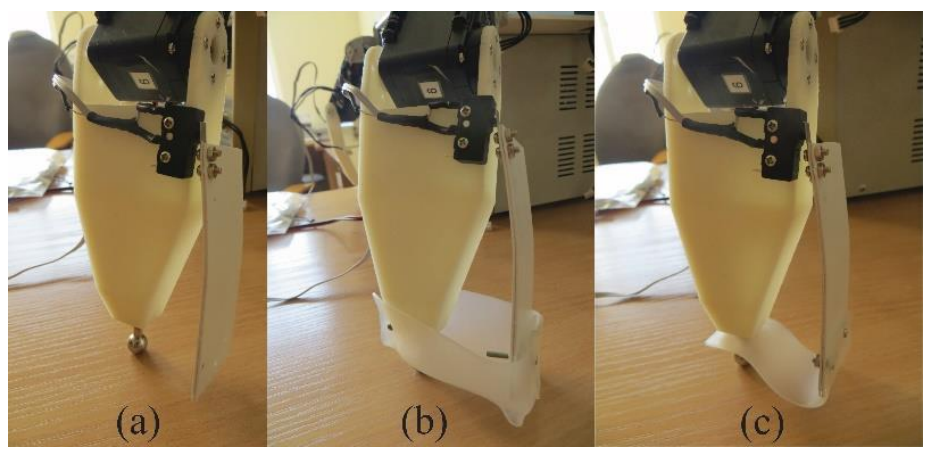

Fig. S2.4. Tactile robot leg sensors attached on leg front side: (a) primary version; (b) secondary version; (c) final version

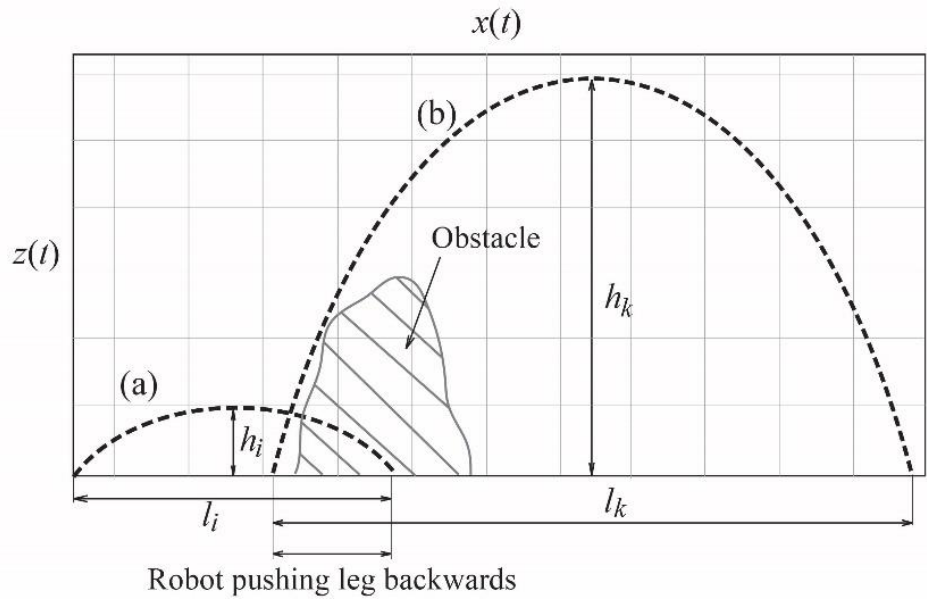

Fig. S2.5. Generating different foot trajectories: (a) for locomotion over even terrain; (b) for stepping over the obstacles

In this work, two different types of obstacle avoidance are used. The simple obstacle avoidance does not require energy consumption minimization, which is why robot only overcomes obstacles by moving legs over the obstacles (Fig. S2.5). The second method is a more complex version, because foot trajectory generation method is improved with leg motion in xy coordinate plane (Fig. S2.6). 


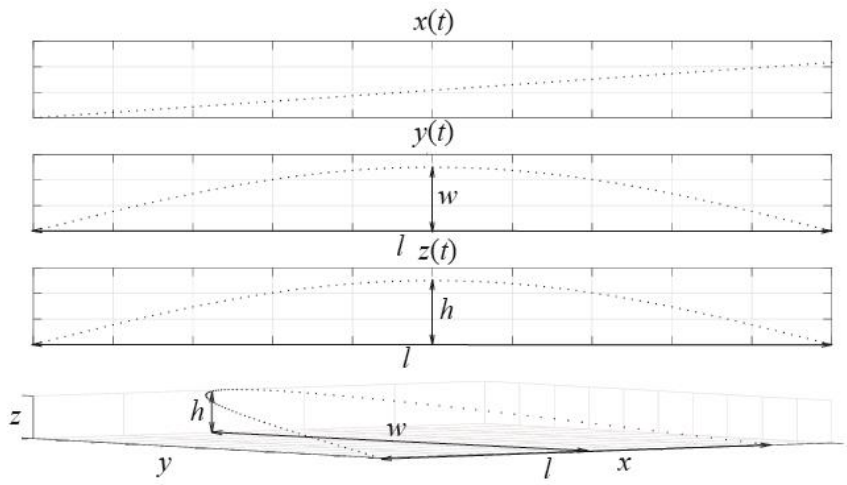

Fig. S2.6. Foot trajectory generation for energy efficient obstacle avoidance

In this work, it was chosen to measure electrical energy of the robot, because measuring the mechanical energy is much more difficult. Full energy of the hexapod robot is calculated using only energy consumed by robot legs, because control system consumes very low amount of energy:

$$
E_{\mathrm{c}}=\sum_{i=1}^{6} E_{\mathrm{ki}}
$$

Before implementing parameter selection, two separate cases of robot locomotion were described. First, robot's leg motions are not synchronized in time. Second, robot's leg motions are synchronized in time. The same parameter selection was used for both cases, but with different references. In first case, selection of minimum foot trajectory distance was used, because changing parameters were step height, and step width:

$$
\arg \min _{w, h, I_{k}}\left(d_{k}\right) \text {. }
$$

In second case, selection of only current consumption was used, because this was the only parameter that was changing:

$$
\arg \min _{w, h}\left(I_{k}\right) .
$$

Also, method for evaluating energy consumption dependence on obstacle sizes and density is developed to observe how energy consumption changes when obstacle density and height increases:

$$
E_{p}=P_{v i d} \cdot\left(S \cdot \frac{l}{v}+\bar{S} \cdot\left(\operatorname{rand}\left(\frac{l}{v}\right)+\operatorname{rand}\left(\frac{l}{v}\right)+\operatorname{rand}\left(\frac{l}{v}\right)\right)\right) .
$$




\section{Research of hexapod robot energetic efficiency}

First of all, hexapod robot movement speeds were determined with which robot consumes least amount of current. Movement speed was obtained by measuring time to cover the given distance. Current consumption was measured using current measuring circuit which was connected directly between power supply and robot's control system (mainly servo motor). To ensure more accurate and reliable results, hexapod robot power consumption was measured for three separate cases: without additional load, using $1.16 \mathrm{~kg}$ load, and using $2.9 \mathrm{~kg}$ load. Main results, showing that wave gait for slower movement, and tripod gait for faster movement should be used, are presented in Figure 3.1.

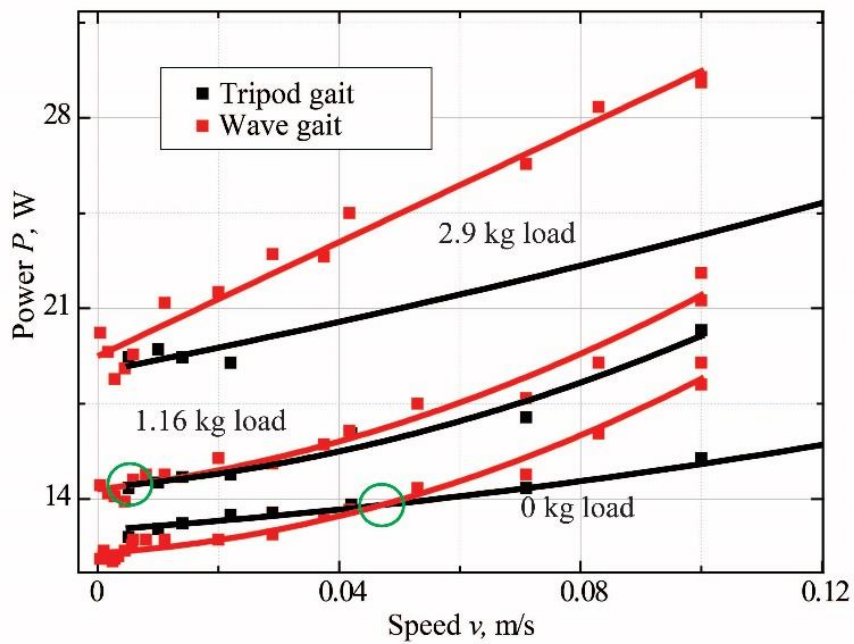

Fig. S3.1. Hexapod robot average power consumption dependence on tripod and wave gaits and speed at different loads

Using obtained information, hexapod robot gait switching algorithm was developed (Fig. S3.2). This algorithm indicates speeds, at which robot has to switch from wave gait to tripod gait in order to sustain minimum energy consumption. Algorithm was implemented directly into hexapod robot's control system and tested through series of experiments. Results are shown in Figure 3.3. 


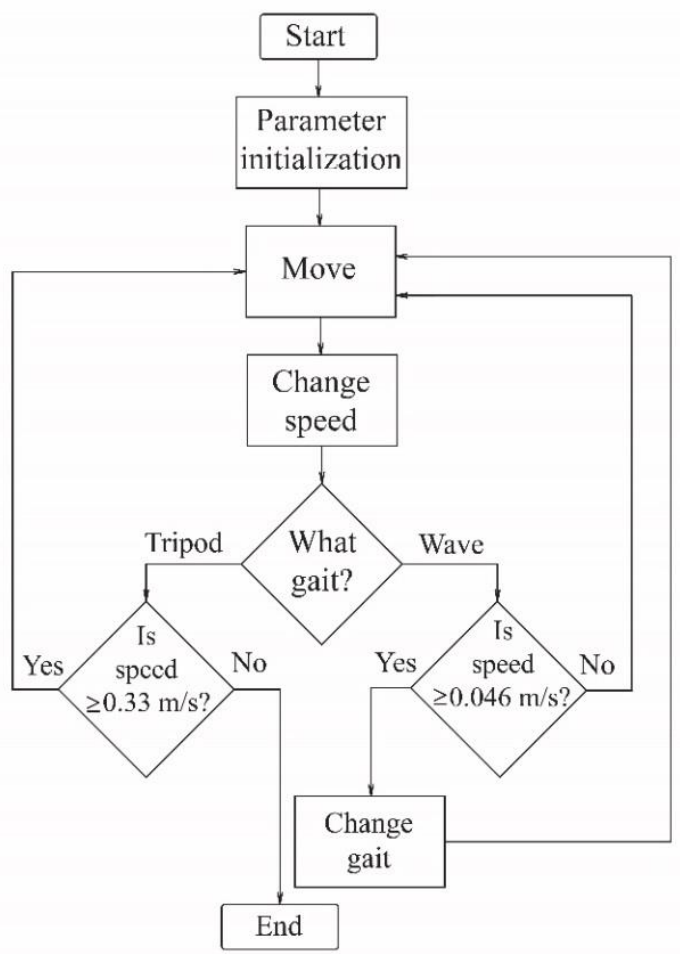

Fig. S3.2. Gait switching algorithm

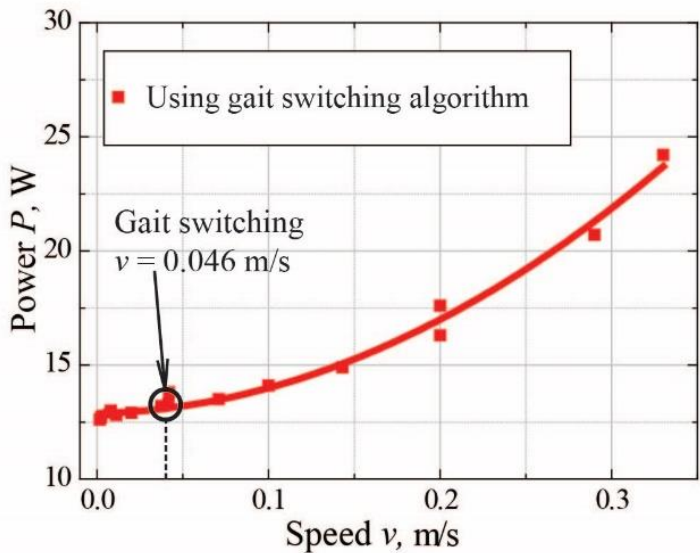

Fig. S3.3. Hexapod robot's average power consumption dependence on speed using gait switching algorithm 
Following experiments were conducted using obstacle detection and avoidance method described in subsection 2.3.2. Due to being most energetically efficient, only wave gait and tripod gaits were used. In addition to using four types of terrains (subsection 2.2), two different distances were given for hexapod robot to travel: $1 \mathrm{~m}$ and $2 \mathrm{~m}$. To be able to evaluate the efficiency of obstacle avoidance method, several experiments were performed without the method.
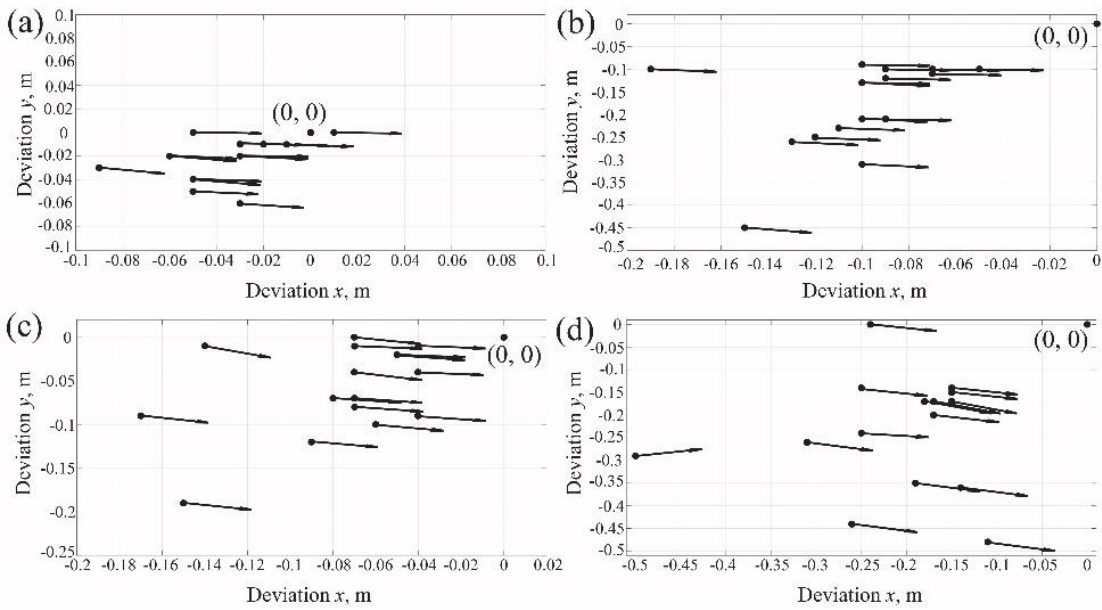

Fig. S3.4. Results of robot locomotion over obstacles using wave gait: (a) low density, $1 \mathrm{~m}$ distance; (b) low density, $2 \mathrm{~m}$ distance; (c) high density, $1 \mathrm{~m}$ distance; (d) high density, $2 \mathrm{~m}$ distance

(a)

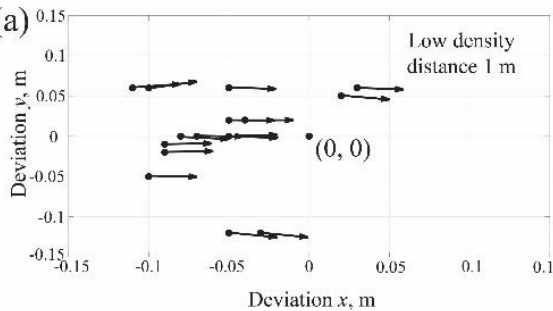

(c)

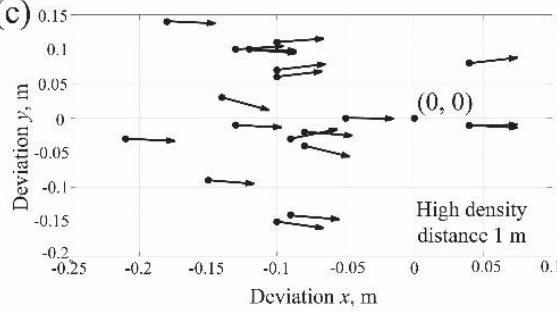

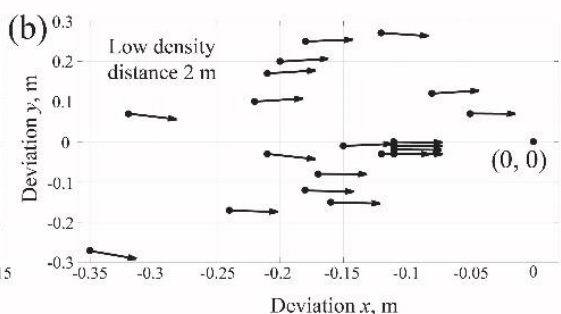

(d)

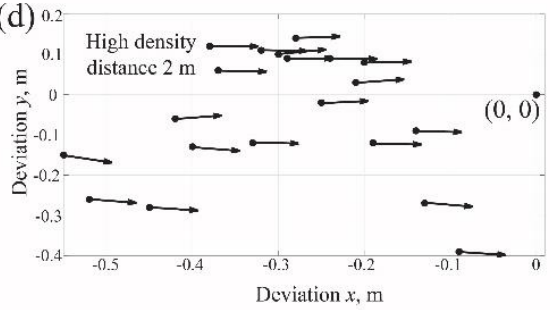

Fig. S3.5. Results of robot locomotion over obstacles using tripod gait: (a) low density, $1 \mathrm{~m}$ distance; (b) low density, $2 \mathrm{~m}$ distance; (c) high density, $1 \mathrm{~m}$ distance; (d) high density, $2 \mathrm{~m}$ distance 
Efficiency of robot's locomotion over obstacles was obtained by measuring $\mathrm{x}$ and $\mathrm{y}$ coordinate deviations from straight path, as well as direction angle change (Fig. S3.4$\mathrm{S} 3.5)$. Results state that wave gait is the most efficient gait for traversing over various size obstacles not depending on density.

Energy consumption during locomotion over obstacles was investigated for two cases: robot leg motions are not synchronized in time, and leg motions are synchronized in time. All experiments, except current identification, were conducted in MATLAB ${ }^{\circledR}$ simulation program. Only tripod gait was used.

In first case, three different obstacle densities were used: low density (10 obstacles), average density (20 obstacles), and large density (30 obstacles). Results are presented in table 3.1. It is clear, that in case of robot leg motions are not synchronized in time, average efficiency of obstacle avoidance method using time independent gaits is $14.9 \%$.

Table S3.1. Average energy consumption of HexaV4 robot locomotion over different density terrains

\begin{tabular}{|c|c|c|c|c|}
\hline Obstacle density & $E, \mathbf{J}$ & $E_{\mathrm{opt}}, \mathbf{J}$ & $E-E_{\mathrm{opt}}, \mathbf{J}$ & $\eta, \%$ \\
\hline Low density & 1551 & 1348 & 203 & 13.1 \\
\hline Average density & 1797 & 1507 & 290 & 16.1 \\
\hline High density & 1851 & 1564 & 287 & 15.5 \\
\hline
\end{tabular}

In second case, different current identification matrix was obtained for better precision, and only 10 obstacles were used during all experiments. Results shown in Table S3.2. Average efficiency of obstacle avoidance method when robot leg motions are synchronized in time is $3.3 \%$, which indicate that this method has very low energy efficiency.

Table S3.2. HexaV4 hexapod robot energy consumption when robot leg motions are synchronized in time. Imitational experiments

\begin{tabular}{|c|c|c|c|c|}
\hline Measurement & $E, \mathbf{J}$ & $E_{\text {opt }}, \mathbf{J}$ & $E-E_{\text {opt }}, \mathbf{J}$ & $\eta, \%$ \\
\hline 1 & 583 & 564 & 19 & 3.4 \\
\hline 2 & 589 & 566 & 23 & 4.1 \\
\hline 3 & 578 & 563 & 15 & 2.7 \\
\hline 4 & 587 & 563 & 24 & 4.3 \\
\hline 5 & 581 & 564 & 17 & 3 \\
\hline 6 & 586 & 565 & 21 & 3.7 \\
\hline 7 & 574 & 565 & 9 & 1.6 \\
\hline 8 & 582 & 563 & 19 & 3.4 \\
\hline 9 & 578 & 564 & 14 & 2.5 \\
\hline 10 & 585 & 563 & 22 & 3.9 \\
\hline Average values & 582 & 564 & 18 & 3.3 \\
\hline
\end{tabular}

To validate the results of obstacle avoidance method, experiments with real hexapod robot were performed. However, because obstacles had to be positioned in line with robot's legs, body of the robot was changed to rectangular shape. For better stability and straight robot motion, wave gait was used, and only 3 obstacles on each side 
were positioned (total 6 obstacles). It is clear from obtained results (Table S3.3), that obstacle avoidance method has indeed very low energetic efficiency, because average efficiency using real robot is $2.4 \%$, which is very similar to imitational experiment results.

Table S3.3. HexaV4 hexapod robot energy consumption when robot leg motions are synchronized in time. Experiments with real hexapod robot

\begin{tabular}{|c|c|c|c|c|}
\hline $\begin{array}{c}\text { Measuring } \\
\text { number }\end{array}$ & $E_{\text {vid }}, \mathbf{J}$ & $E_{\text {vid_opt }}, \mathbf{J}$ & $E_{\text {vid }}-E_{\text {vid_opt }}, \mathbf{J}$ & $\eta, \%$ \\
\hline 1 & 14.71 & 14.44 & 0.27 & 1.9 \\
\hline 2 & 14.6 & 14.27 & 0.33 & 2.3 \\
\hline 3 & 14.7 & 14.27 & 0.43 & 3 \\
\hline
\end{tabular}

During previous experiments it was concluded, that energy consumption depends on obstacle sizes and density. However, it was not completely clear, which of these parameters has more influence. In this section, energy consumption dependence on obstacle sizes and density is described.

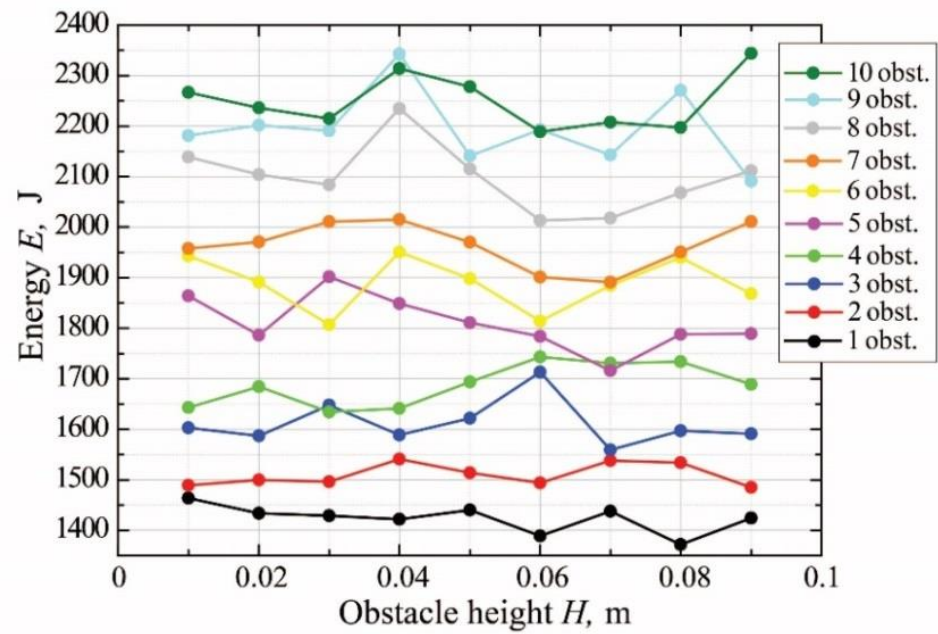

Fig. S3.6. Energy consumption dependence on obstacle height with different number of obstacles along robot's path

Because energy consumption is not dependent on step width, obstacle avoidance was performed only by transferring legs over the obstacles. This was also the reason for measuring new current identification, but only to obtain current dependence on step height. Also, reference measurements were performed. During these tests, no obstacles were used, but different travel distances were given for robot to cover $(1-4 \mathrm{~m})$. Final energy consumption dependence on obstacle sizes and density are presented in figure 3.6. It is obvious that obstacle height has very low influence on energy consumption, but is strongly influenced by obstacle density. It costs the same amount of 
energy to travel $1 \mathrm{~m}$ with 10 obstacles in the path or to travel $2 \mathrm{~m}$ distance without obstacles.

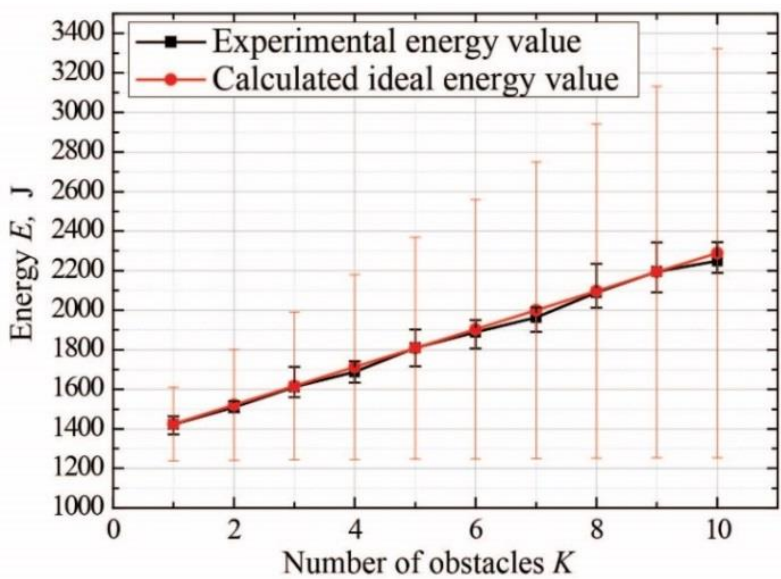

Fig. S3.7. Energy consumption dependence on obstacle density. Red deviation lines represent minimum and maximum possible energy values

After all experiments were conducted, all energy consumption values were recalculated into average values, because energy consumption is almost not dependent on obstacle height. Also, theoretical energy consumption values were calculated to evaluate all possibilities (Fig. S3.7). It was concluded from figure 3.7, that theoretically it is possible for robot to always use minimum amount of energy.

\section{General conclusions}

1. After performing analysis of mobile robots it was concluded, that the main advantage of walking robots is their ability to traverse irregular terrains and to adapt to various environments. It was also concluded, that the biggest disadvantage of walking robots, compared to wheeled robots, is high energy consumption, which appears due to large number of actuators or inefficient control methods.

2. Imitational model of hexapod robot was developed with possibility to calculate energy consumption. Current consumption results were obtained during experimental research. This model is universal and can be used to perform robot locomotion and energy consumption experiments. Imitational model allows conducting more experiments, which increases the efficiency of research.

3. Walking robot's energy consumption is dependent on gait and movement speed. Up to $7.7 \%$ lower energy consumption can be obtained using wave gait instead of tripod gait at lower speeds ( 0.184 body lengths/s or lower), and up to $21 \%$ lower energy consumption can be obtained using tripod gait instead of wave gait at higher 
speeds ( 0.184 body lengths/s or higher). Lowest cost of transport value -5.75 was obtained when hexapod robot was walking using tripod gait at highest speed, which is 1.32 body lengths/s

4. Developed obstacle detection and avoidance method can be used for walking robots. Without using obstacle avoidance method average deviations from given trajectory can reach up to $24 \%$ travelling $1 \mathrm{~m}$ distance, while using obstacle avoidance method, average deviations from given trajectory can be minimized down to $12 \%$ not depending on travel distance. Smallest deviations can be obtained by using wave gait while travelling on terrain with lower amount of obstacles.

5. Energy consumption is dependent on obstacle size only when robot leg motions are not synchronized in time. In this case up to $14.9 \%$ lower energy consumption can be obtained by selecting shorter foot trajectory length. If robot's leg motions are synchronized in time, only about $3.3 \%$ lower energy consumption can be obtained. In this case, robot's energy consumption is highly influenced by the number of obstacles along the robot's path. It was concluded that every additional obstacle along one meter of robot's path, not depending on the size of the obstacles, increases robots energy consumption by $7 \%$. 



\section{Priedai $^{3}$}

A priedas. Disertacijos autoriaus sąžiningumo deklaracija

B priedas. Bendraautorių sutikimai teikti publikaciju medžiagą disertacijoje

C priedas. Autoriaus mokslinių publikacijų disertacijos tema kopijos

${ }^{3}$ Priedai pateikiami pridètoje kompaktinèje plokštelëje. 
Mindaugas LUNECKAS

ŠEŠIAKOJO ROBOTO JUDĖJIMO ENERGETINIO

EFEKTYVUMO TYRIMAS

Daktaro disertacija

Technologijos mokslai,

elektros ir elektronikos inžinerija (01T)

INVESTIGATION OF ENERGY EFFICIENCY OF

HEXAPOD ROBOT LOCOMOTION

Doctoral Dissertation

Technological Sciences,

Electrical and Electronic Engineering (01T)

201804 17. 11,75 sp. I. Tiražas 20 egz.

Vilniaus Gedimino technikos universiteto

leidykla „Technika“,

Saulètekio al. 11, 10223 Vilnius,

http://leidykla.vgtu.lt

Spausdino UAB „BMK leidykla“"

J. Jasinskio g. 16, 01112 Vilnius 